\title{
وقف المنافع في الفقه الإسلامي بحث فقهي مقارن
}

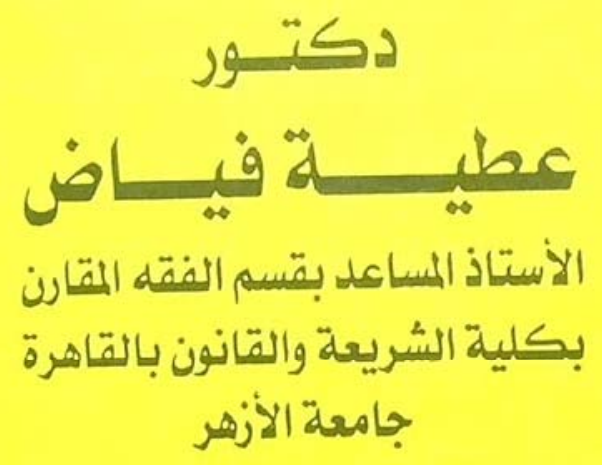




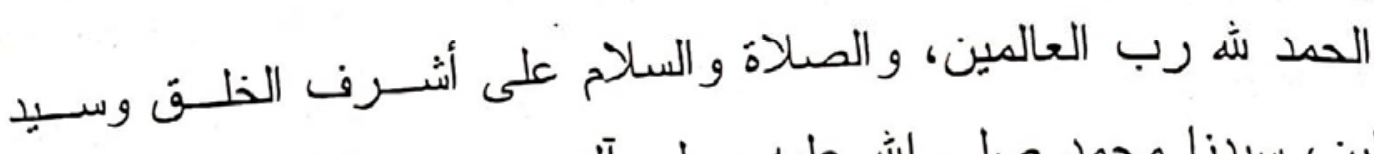

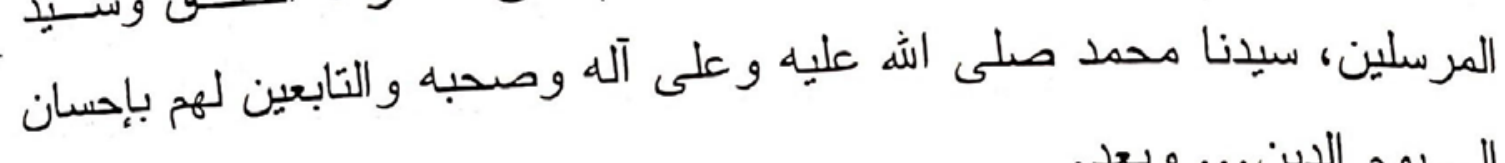

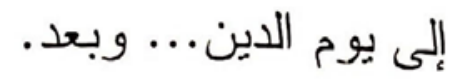

فإن الوقف في الإسلام ليس مجرد عمل من أعمال التبرع ع التــي يـؤجر

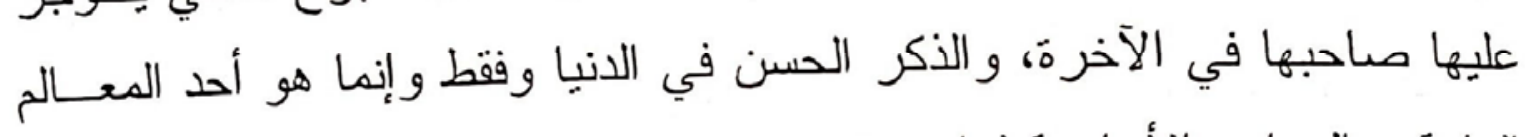

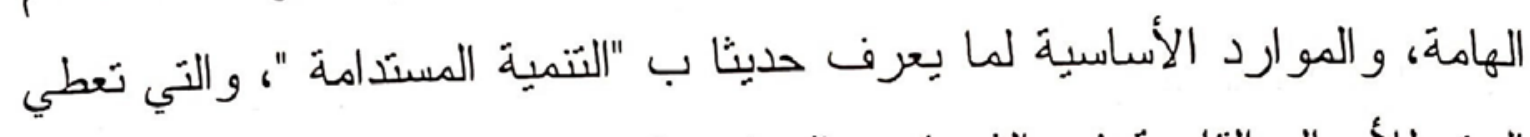

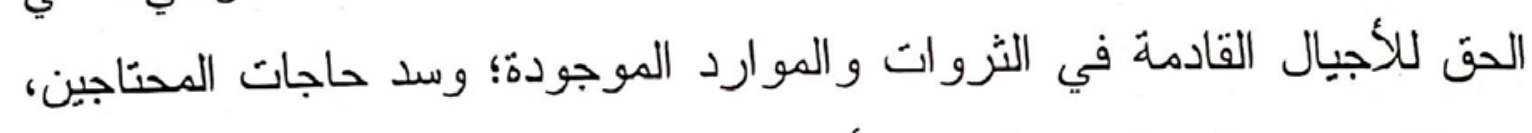
وتحقيقَ مجتمع التضامن و التكافل، أو مجتمع الجسد الو احد.

ولما تقام فقل عده الإسلام من أفضل الأعمال و القربات، وندب إليه بكافــة

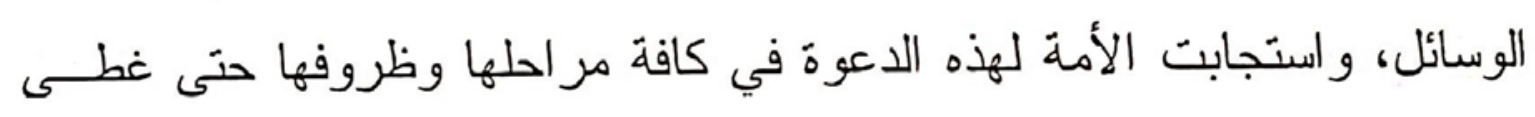
الوقف كافةَ مجالات الحياة المختلفة، ولم يقتصر دوره على دور العبادة فقط إنما

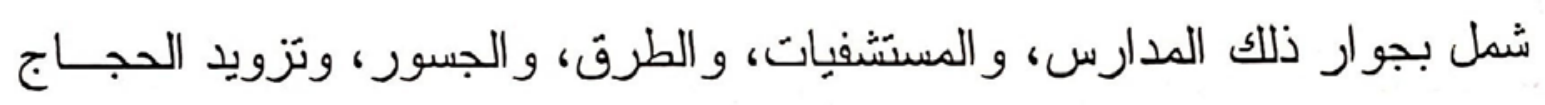

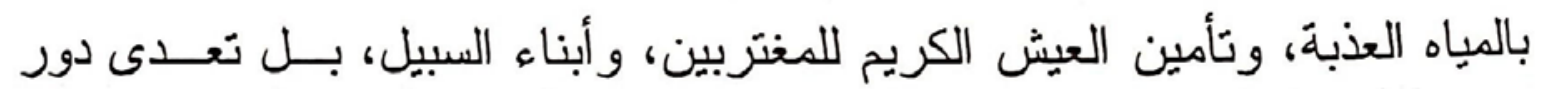
الوقف ليؤمن الحياة الكريمة للحيو انات و الطيور ونحوها، وكانت مؤسسة الوقف

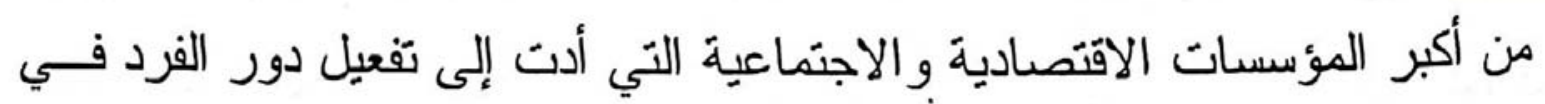

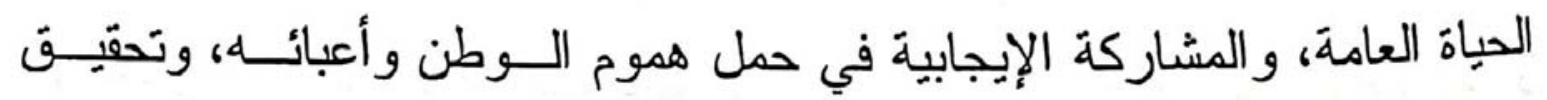

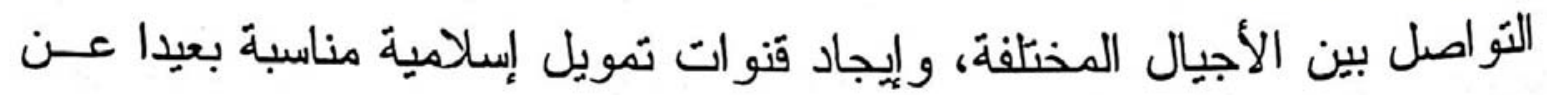
القروض الربوية وشروطها المجحفة التي تزيد الفرد والأمة المقترضة ذل النهار و هم الليل، وتوقعهما في حرب مع الهو ورسوله. 


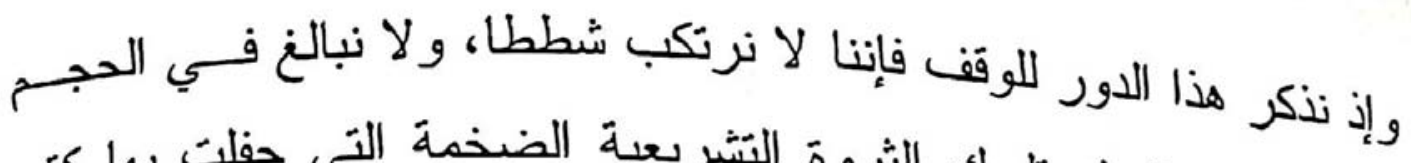

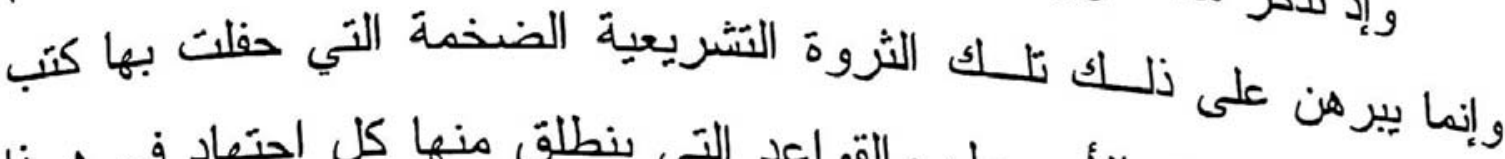

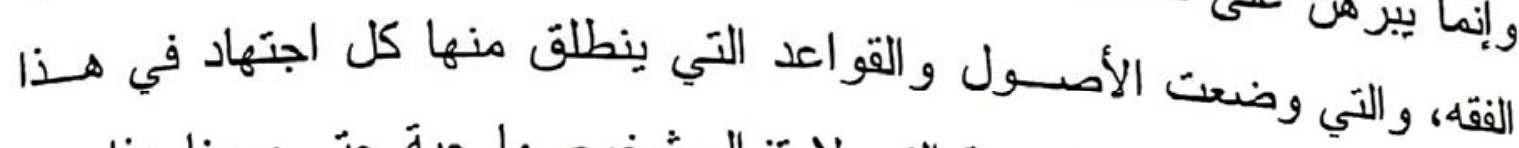

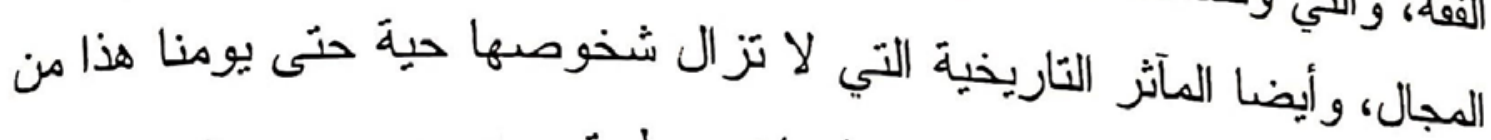

$$
\text { مساجد، ومدارس، ومستشفيات، وجامعات، وطرق وجسور ل... }
$$

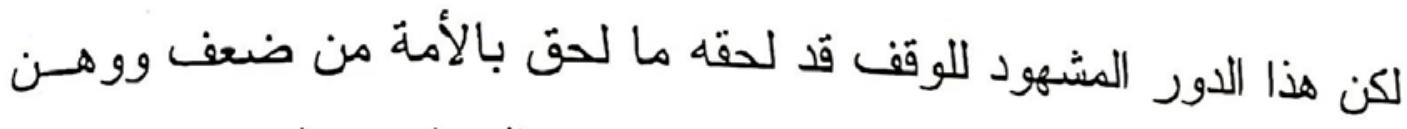

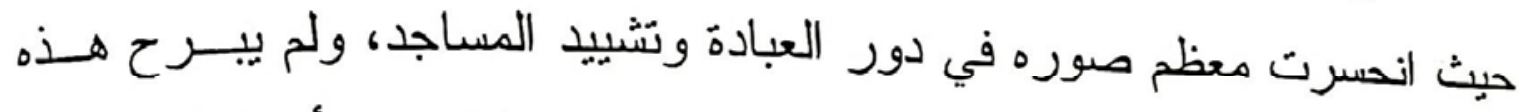
المجالات إلا قليلا، وألغيت كثير من صوره، وتحولت كثير من أموال الوقف إلى لى لى

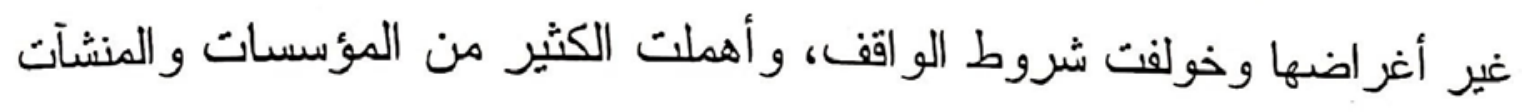
الوقفية وسطا عليها اللصوص، وتوقف الاجتهاد الفقهي عند الصور التي ذكرها

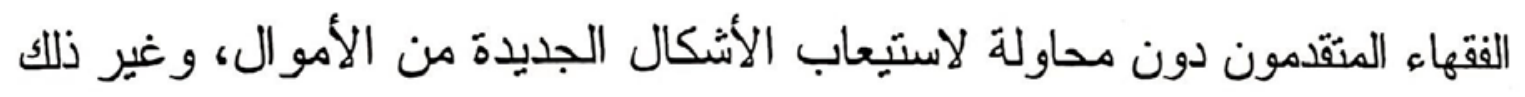

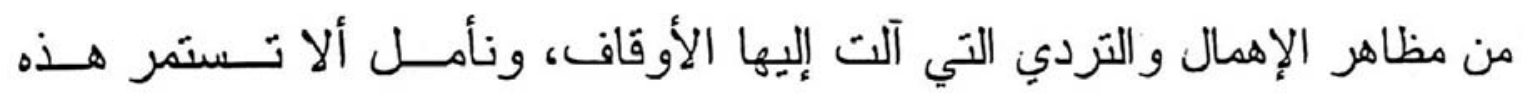

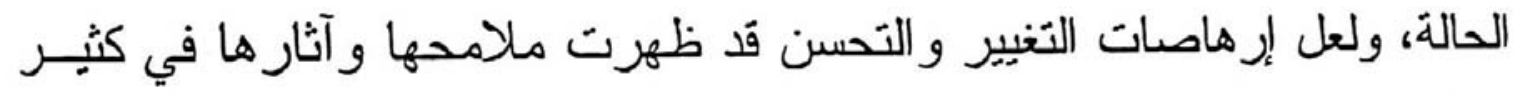

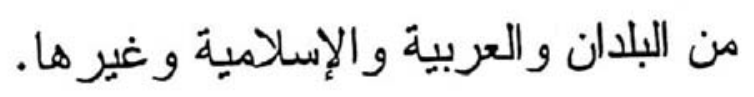

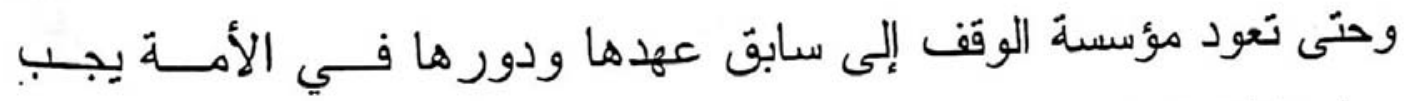

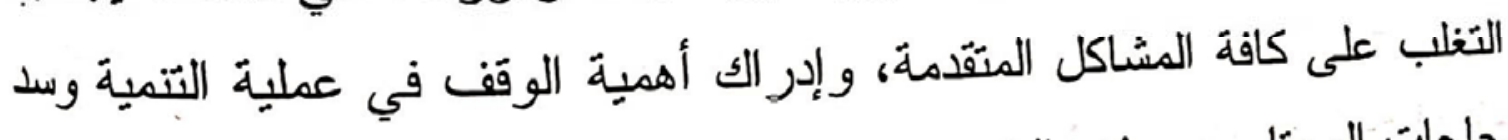

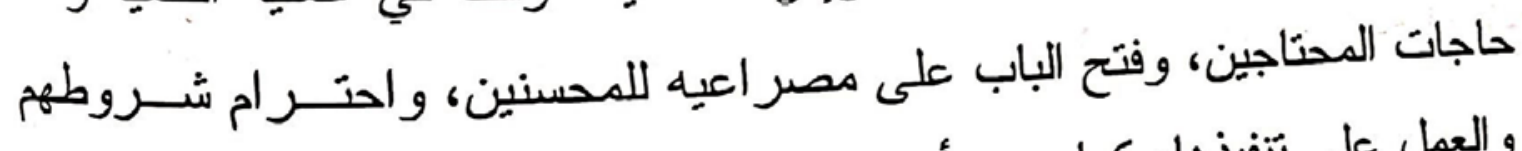

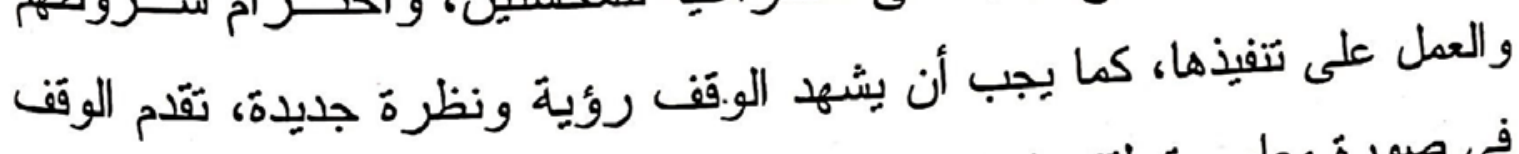

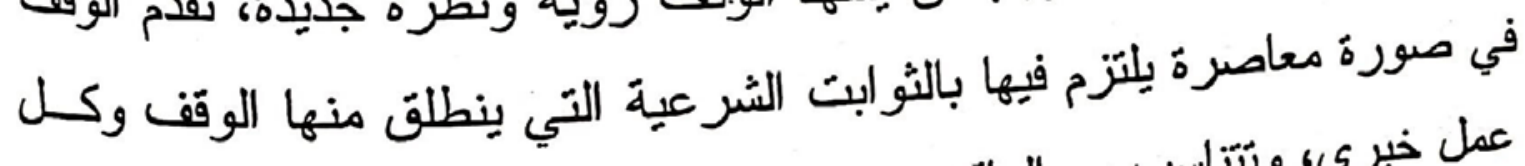

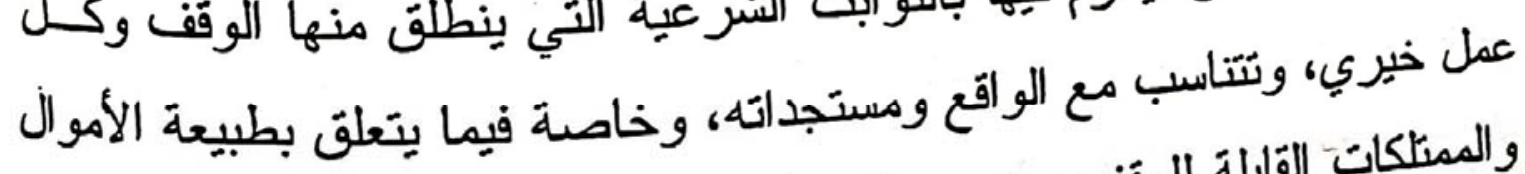

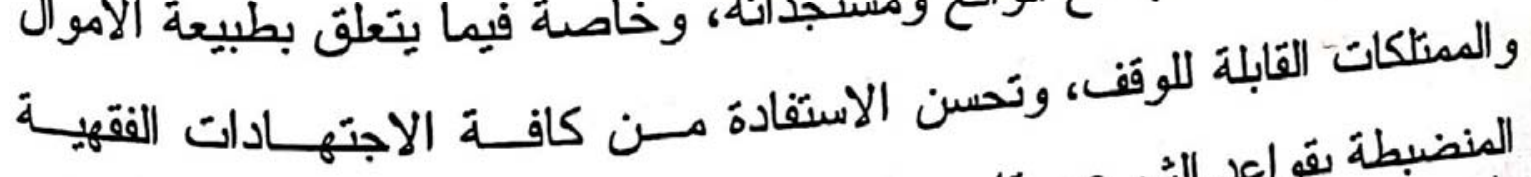

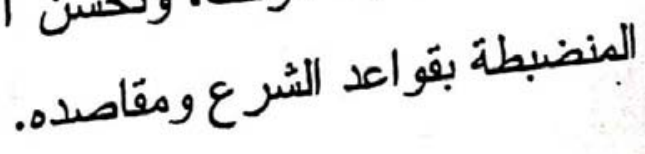


ويأتي بحث " وقف المنافع في الفقه الإسلامي " في هـــا الإطـــار ليَــدم

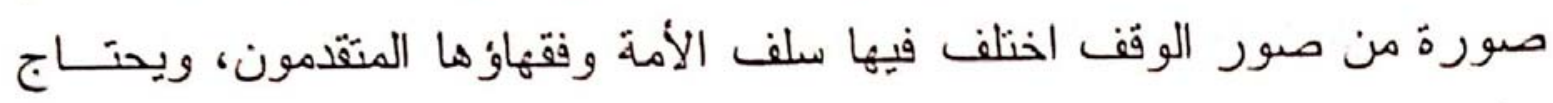

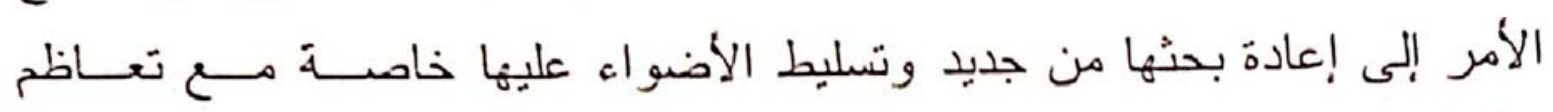

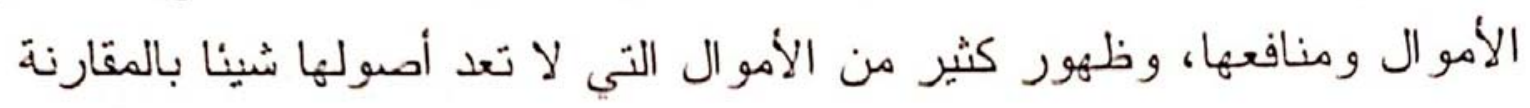

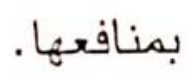

لقد برزت أسئلة كثيرة في أذهان المسلمين وتحتاج إلى إجابات حاســمة، ومنها:

هل يمكن لماللك سيارة أن يوقف منفعة سيارته في أوجه البــر

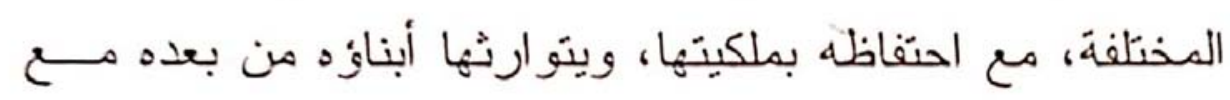

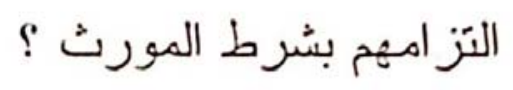

هل يمكن لمدرس أو لطبيب أو لمهندس أو لفني صيانة أجهـــة

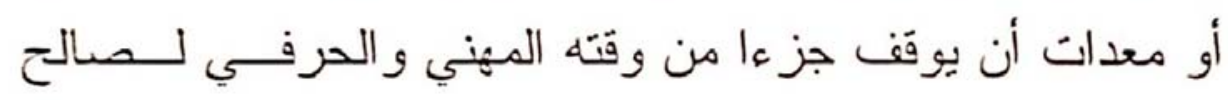

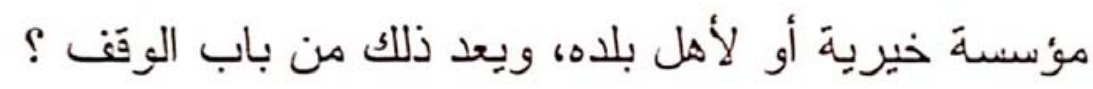

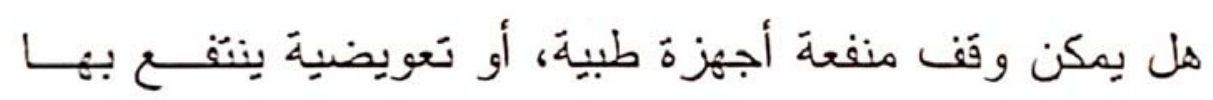
المرضى وتظلل مملوكة لمن اشتر اها؟ هل يِكن وقف ساعات محددة يومية من قَنــاة تلفزيونيــة، أو صفحات من موقَع الكتروني ونحو ذلك ؟

هل يجوز الوقف المؤقت لتلاك المنافع، يوم أو يومين من كـلـ

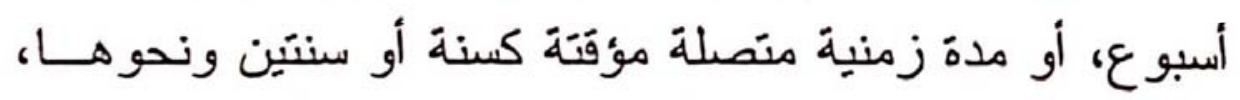

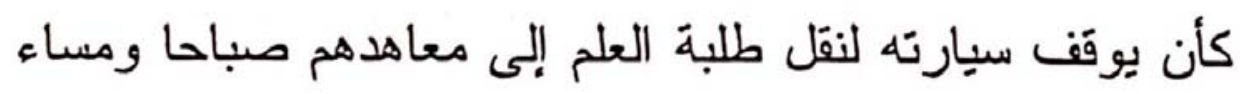

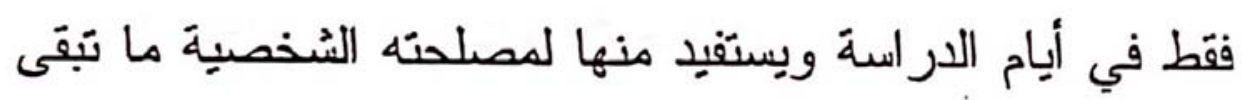

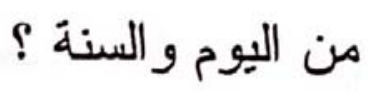


لا شك أن هناك عشر ات أخرى من الأسئلة تر اود المسلمين في هذا الباب،

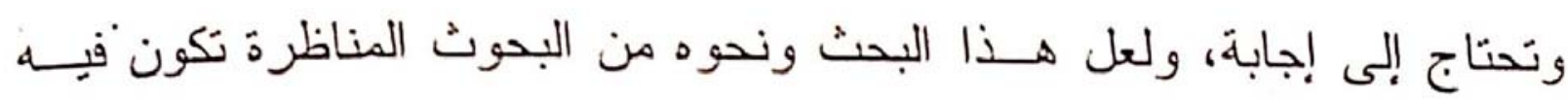

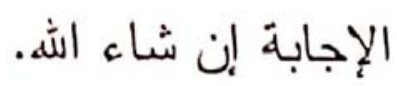

\section{موضوع البحث و هلفه ومحتو اه:}

موضو ع البحث " وقف المنافع في الفقه الإسلامي - بحث فقهي مقــارن "

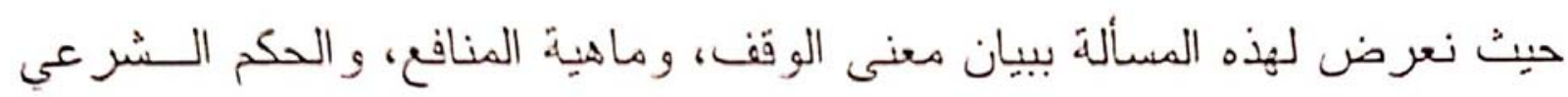

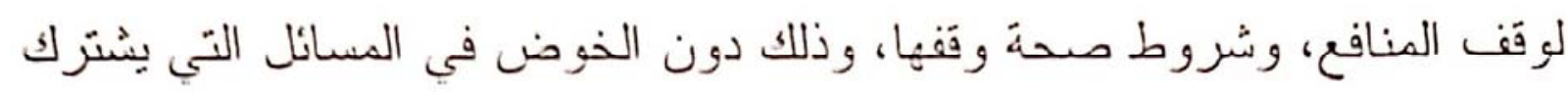

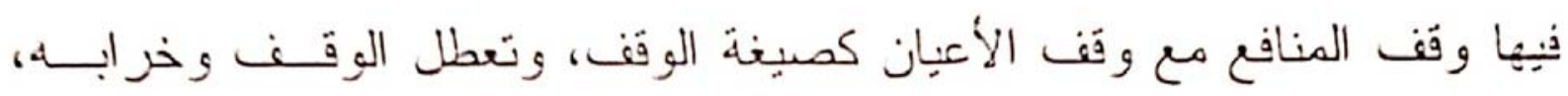

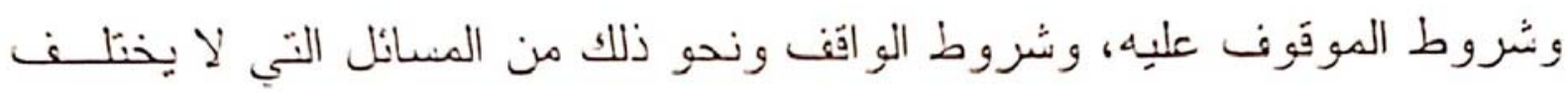

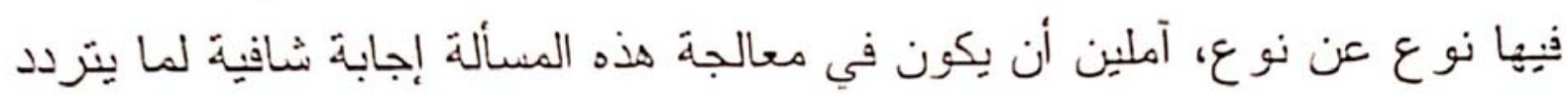

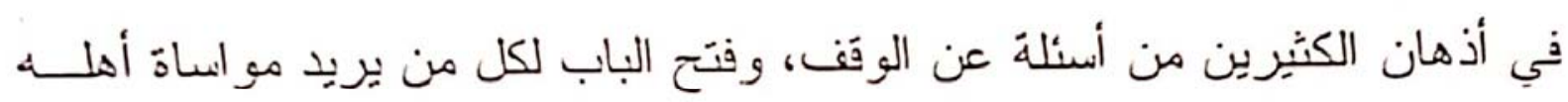

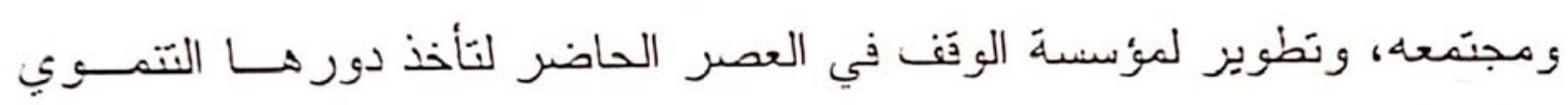

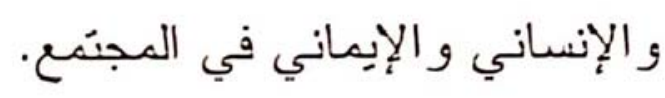

وتحنَوي هذه الدر اسة على تمهين وأربعة مباحت وخاتمَة

في التمهيد: تعريف الوقف، وحكمه.

المبحث الأول: ماهية المنافع ومدى اعنبار ها أموالا.

المبحث الثًاني: حكم وقَف المنافع سواء أكانت للأشخاص أو الأشياء. المبحث الثالث: شروط وقف المنافع. المبحث الر ابع: الوقف المؤقَت للمنفعة. خاتمة: وبها أهم نتائج وتوصيات البحث. رب اشرح لي صدري، ويسر لي أمري، واحلل عقدة من لساني، يفقهو قولي 


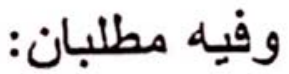

\section{المطلب الأول: تعريف الوقف.}

الوقَف لغة: الحبس، يقال: وقفت كذا أي حبسته، و أوقفت كذا لغة تميمية

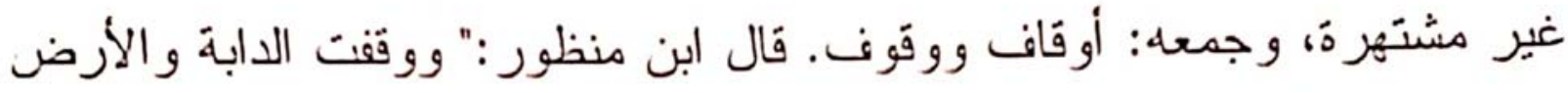

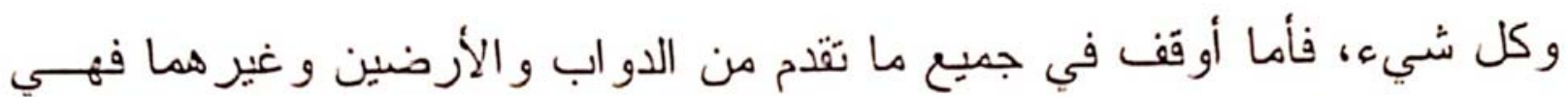

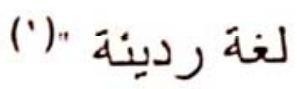

وكثير ا ما يعبر عنه في كتب الفقه بـ " الحبس " فهما منر ادفان و الفصيح

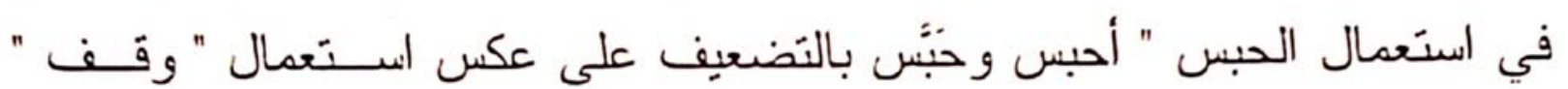

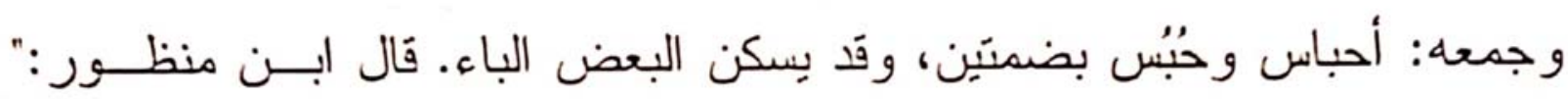

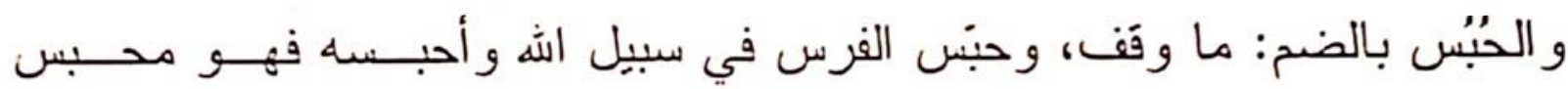

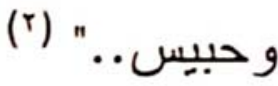

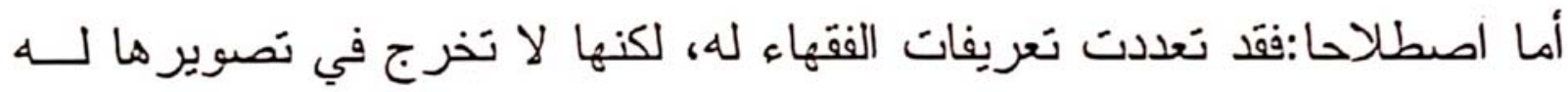

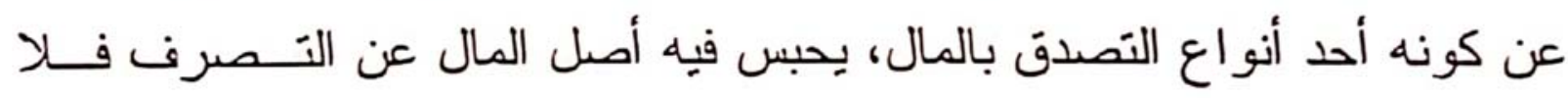

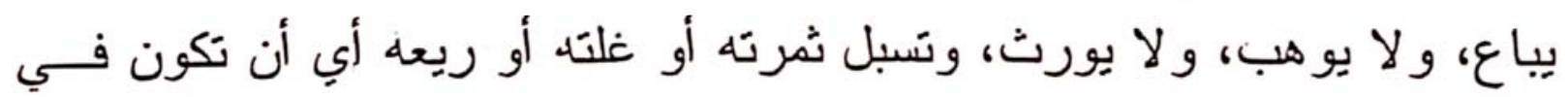

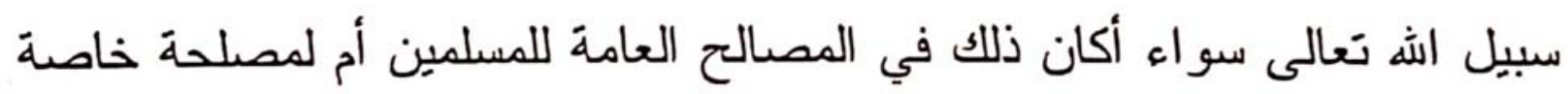
بالأفر اد.

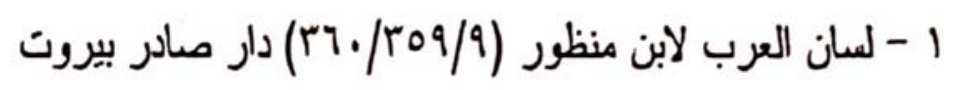

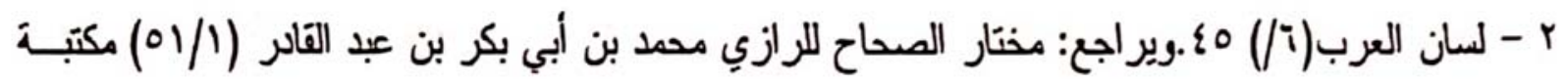

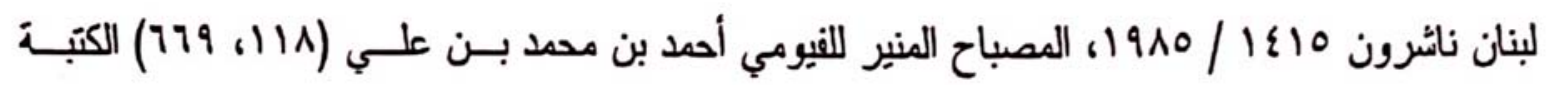
العلية، المغرب لأبي المكارم المطرزي (19 §و) دار الكتاب العربي. 


\section{ويرجع الخلاف في تعريف الوقف إلى اختلاف العلماء في ثلاث مسانل:}

الأولـى مــــى جــواز تصرف الو اقف في المال الموقوف أو الرجوع

وقد أسفر هذا الخلاف في هذه المسألة عن تعريفين للوقف: أحدهما: يبرز

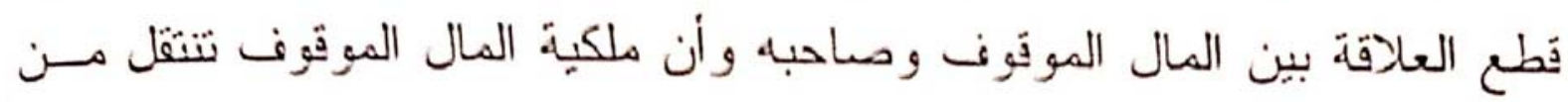

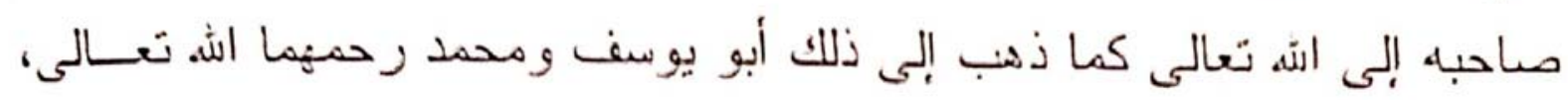

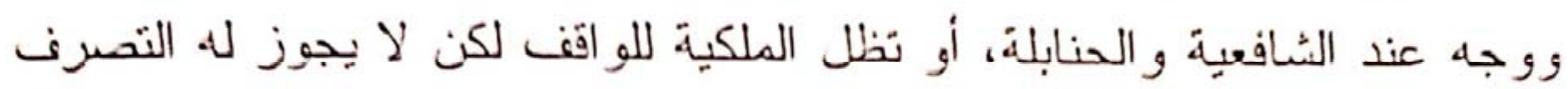

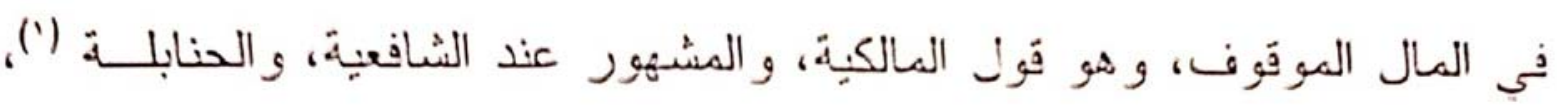

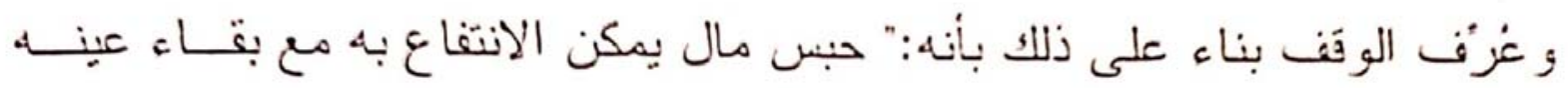

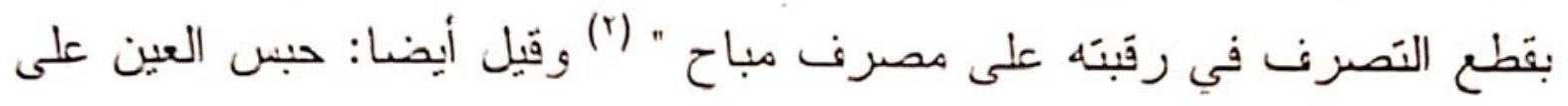

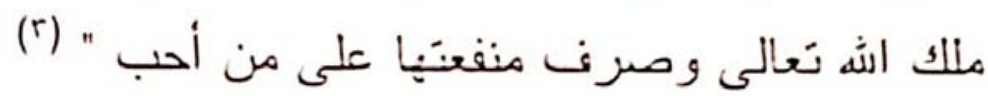

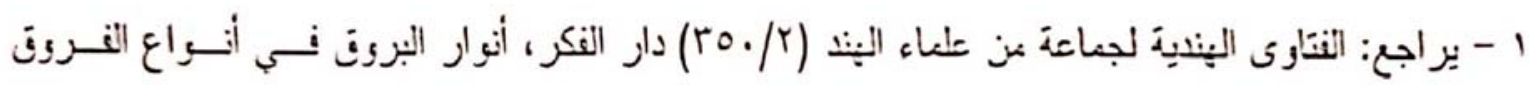

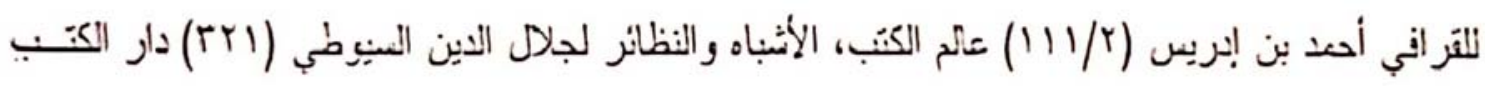

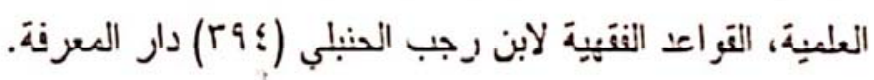

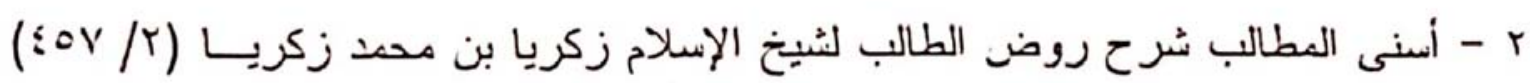

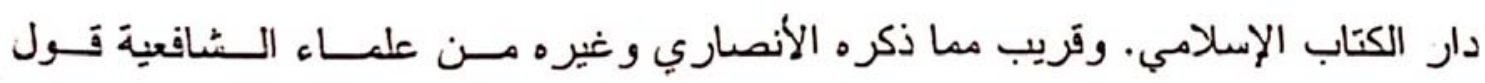

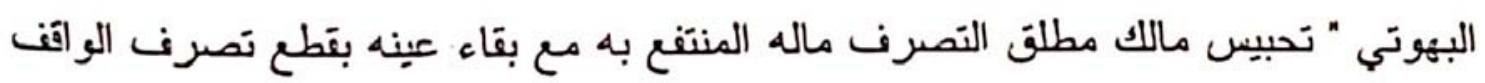

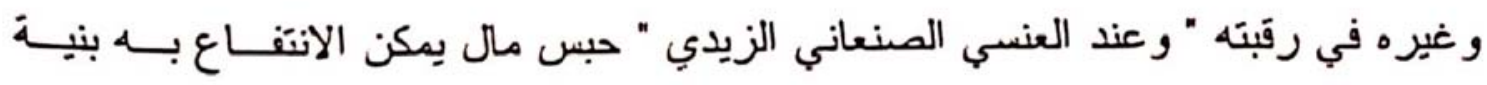

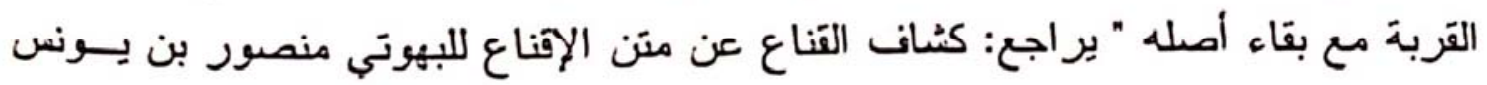

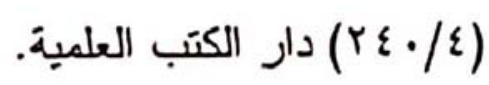

ولم ير المالكية هذا التعريف للوقف لاختلافهم مع الجمهور في طبيعة المال الموقون كما

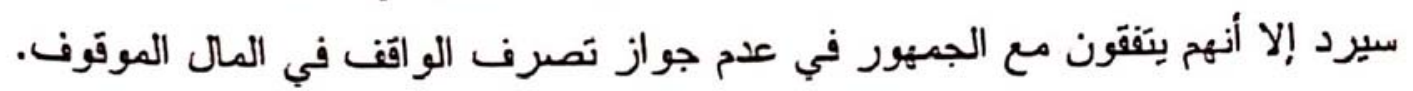

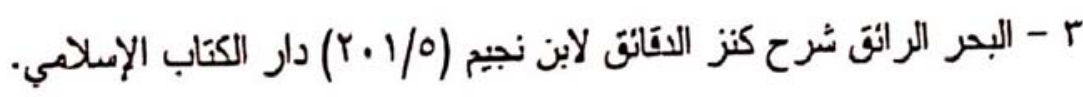


و الثاني: يؤكد هيمنة الو اقف على المال الموقوف، ولا ينتقل عن ملكه إلا

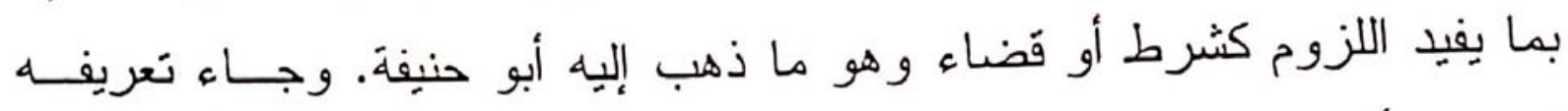

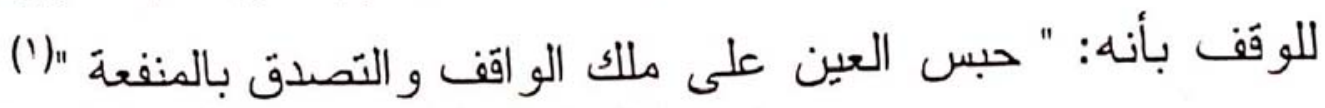
و الفرق بين قَول أبي حنيفة، ومن رأى أن الوقف لم يخرج عـن ملكبـــة

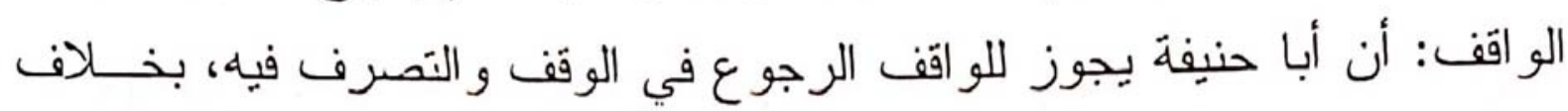

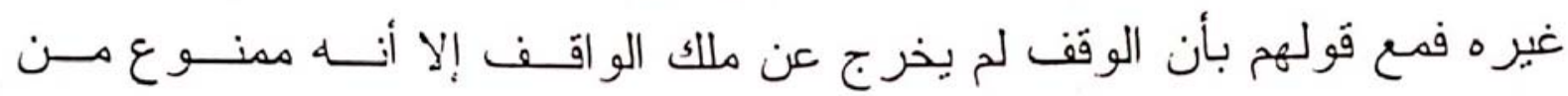

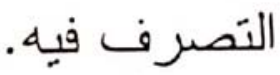

الثانيةة: مدى لزوم وقف أصل المال ومنفعته معا، فقد ذهب الجمهور مـنـن

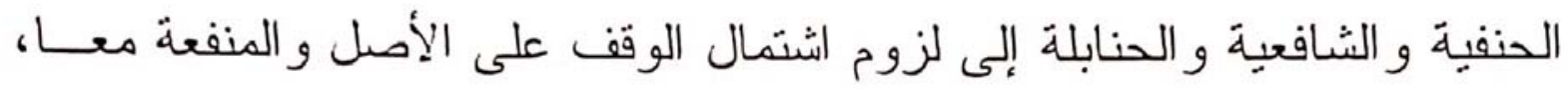

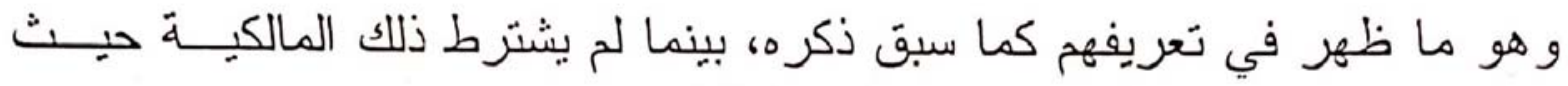
أجازوا ورود الوقف على المنفعة فقط ولو دون أصلها؛ ولذا قَالوا في تعريفه: "

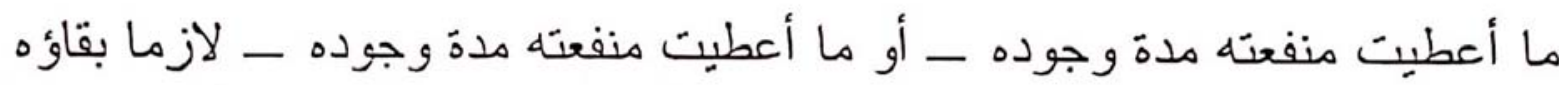
في ملك معطيه ولو ثقديرا "(r) ويلاحظ أن التعريف عبر بإعطاء منفعة شيء ولم يعبر عنه بأنه " حــبس

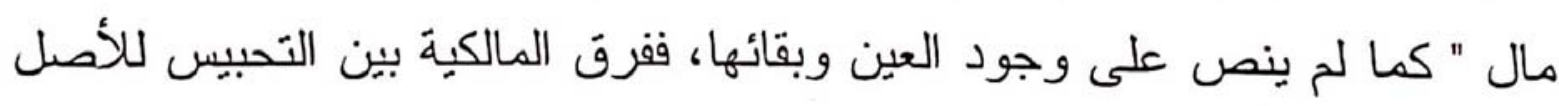

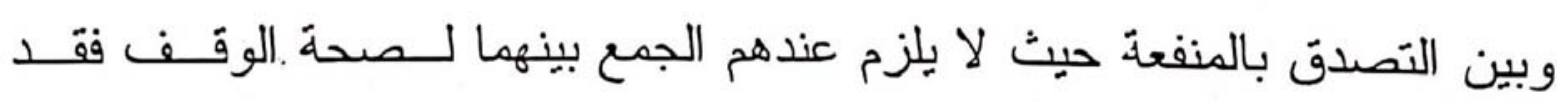
يتصدق الشخص بالمنفعة ويظل محتفظا بملكيته للأصل، وهو ما يظهر بالتفصيل في ثنايا البحث إن شاء الشه تعالى. بأل

I - المبسوط لشمس الأثمة السرخسي (YY/YY) دار المعرفة، البحر الرائق ـ الموضع السابق.

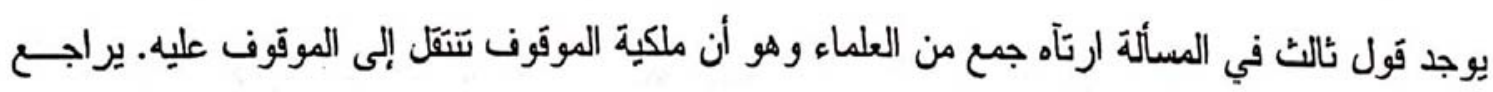

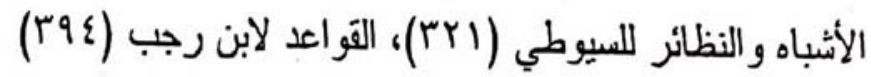

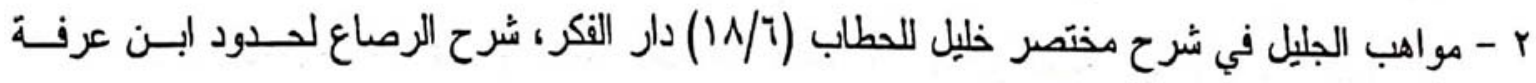

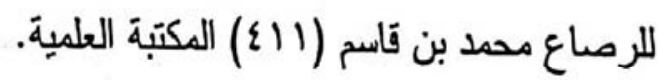




\section{الثالثة: اشتراط التأبيد في الوقف.}

وهو خلاف الجمهور مع المالكية، حيث ذهب المالكية في الراجح عندهم

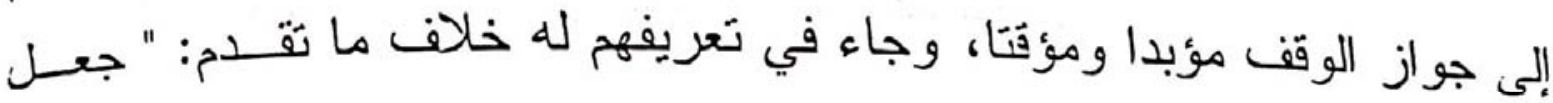

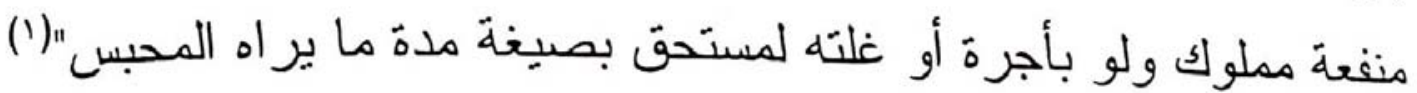
قال الدردير في شرح التعريف:" (جعل منفعة مملوك) من إضافة المصدر

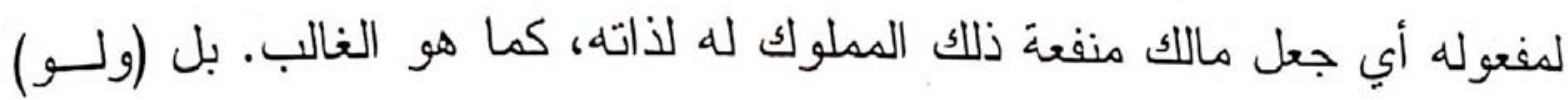

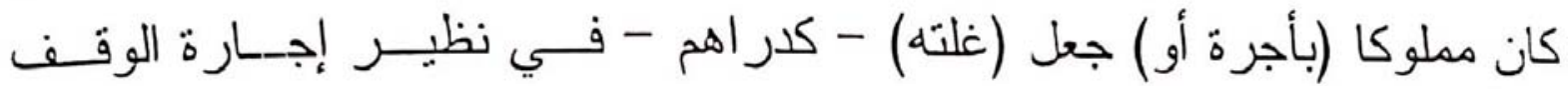

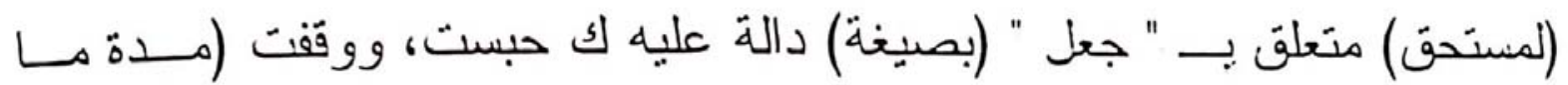

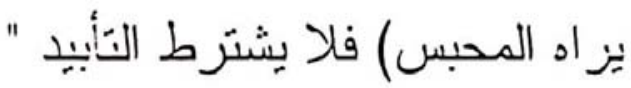

و لا يناسب التمهيد أن نعرض لمسائل الخلاف بالمناقشة و البيان حتـى لا

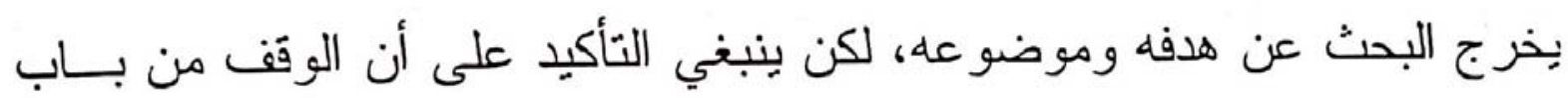

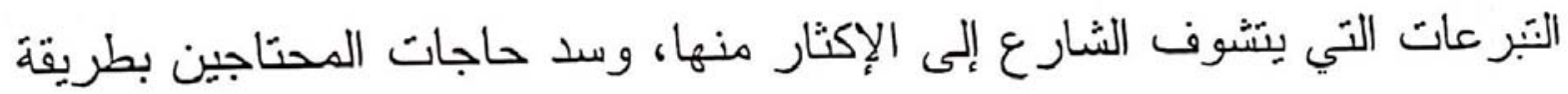

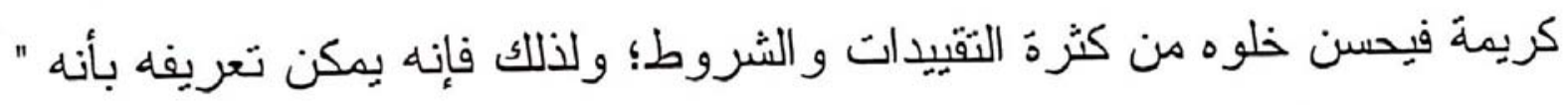

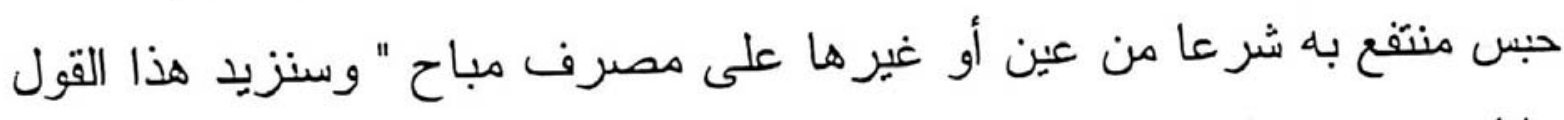

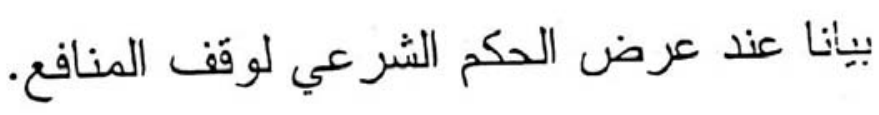

فيشمل بذلك وقف الأعيان و المنافع و الحقوق المعتبرة شرعا وقفا دائما أو

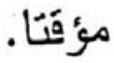

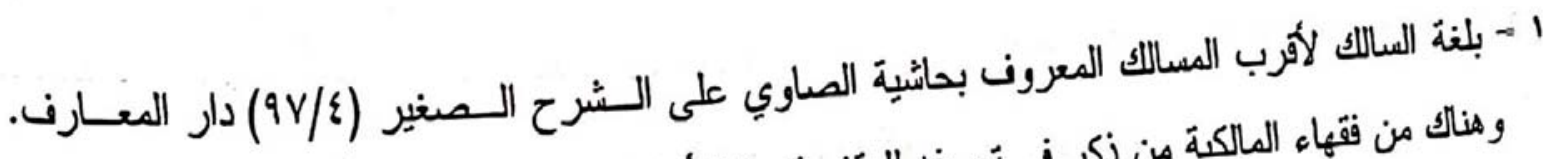

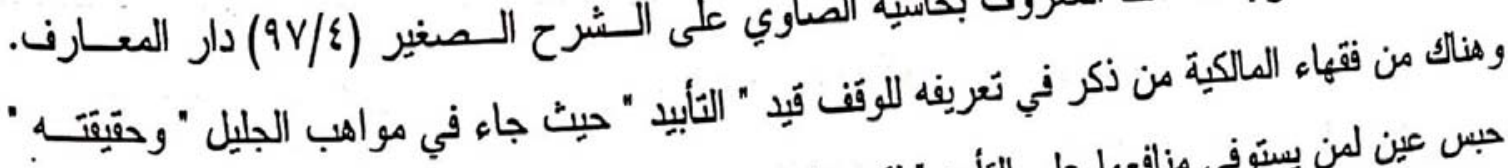

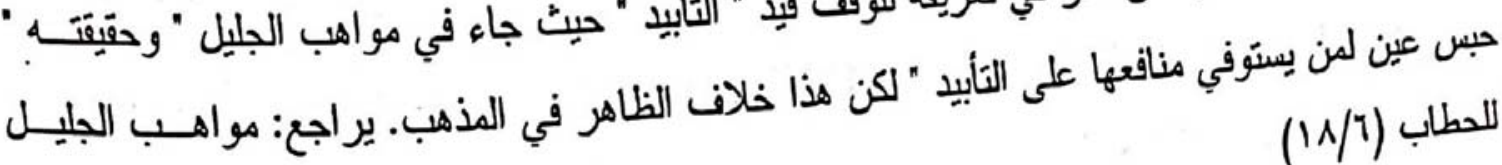
للحطاب (1N/T) 


\section{المطلب الثاني: حكم الوقف:}

حــث الإســلام علــى الوقف، وجعله من أفضل القربات المالية التــي

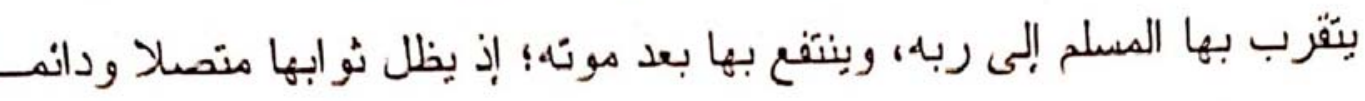

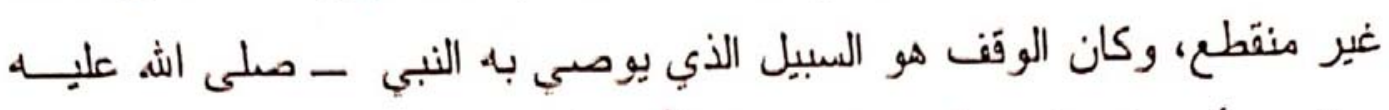

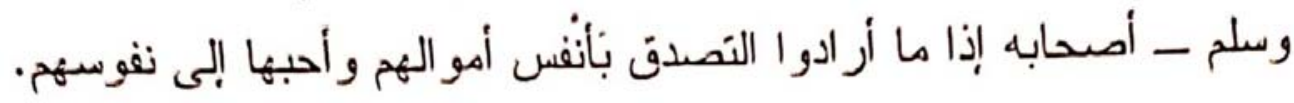

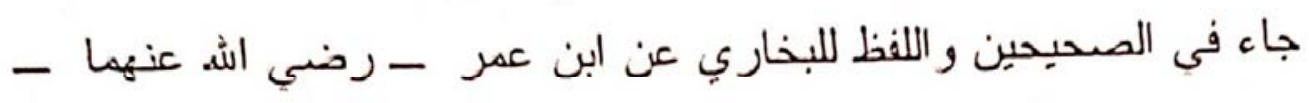

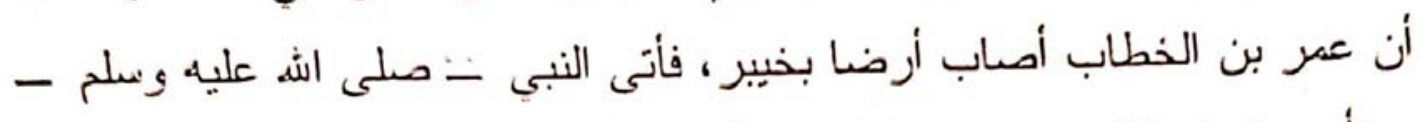

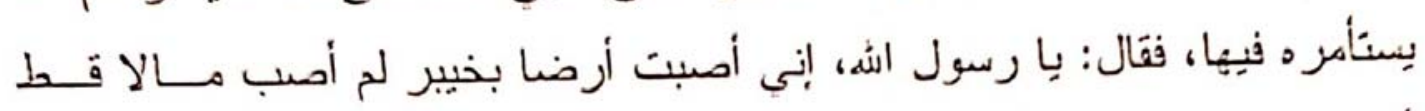

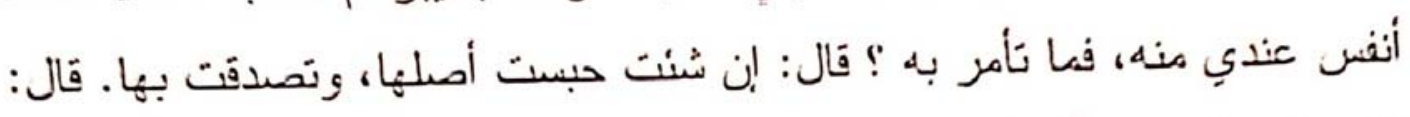

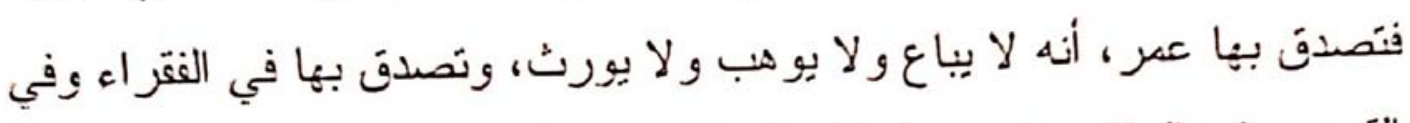
القربى وفي الرقاب وفي سبنل الهه وابن السبيل و الضيف، لا جناح على من وليهيا أن يأكل منها بالمعروف ويطعم غير منمول" (1)

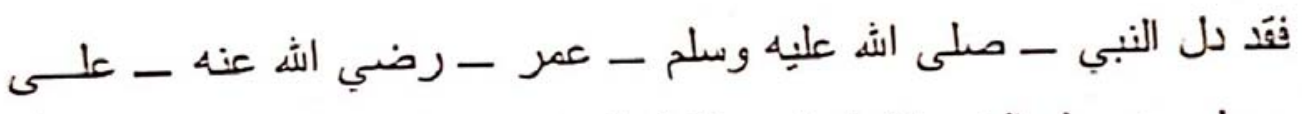
أفضل سبيل من سبل الخير ليفعله في هذا المال الحبيب إلى نفسه. قَال النووي:" وفي هذا الحديث دليل على صدة أصل الوقف، و أنه مخالف

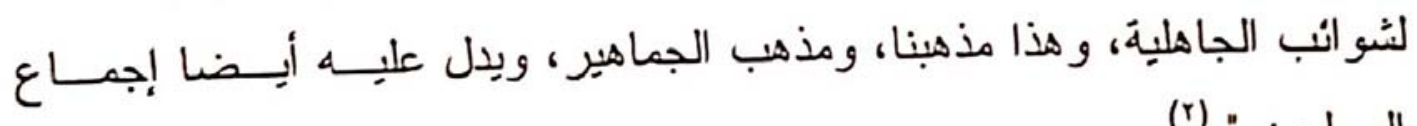
(r) المنسمين "

وفي الصحيحين و اللفظ للبذاري عن إسحاق بن عبد اله بن أبي طلحة أنه سمع أنس بن مالك رضي اله عنه يقول: كان أبو طلحة أكثر الأنصار بالمدينـــة

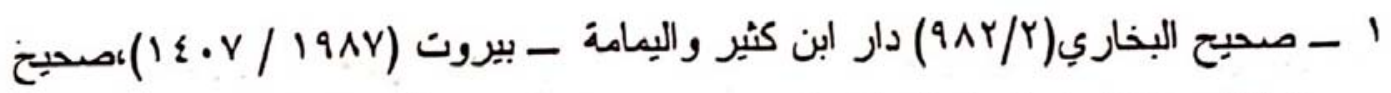

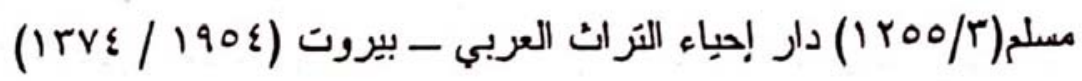

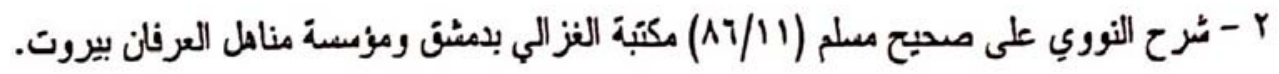


مالا من نخل، وكان أحب أمو اله إليه بِيرحاء، وكانت مستقَبلة المـسجد، وكـــان

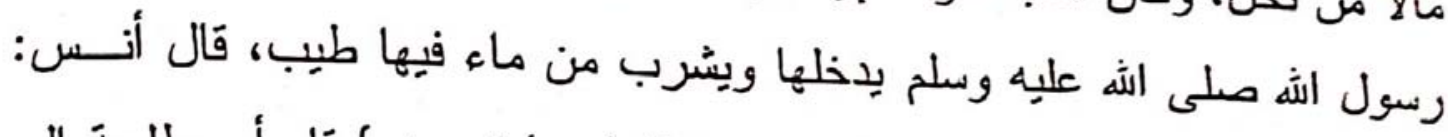

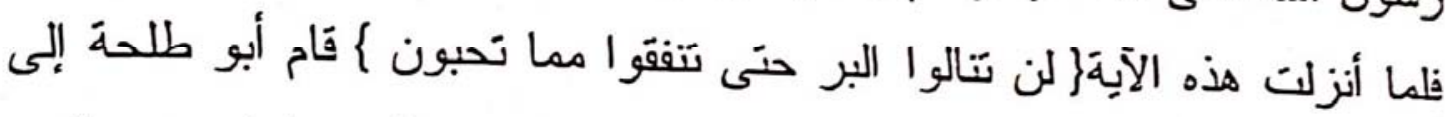

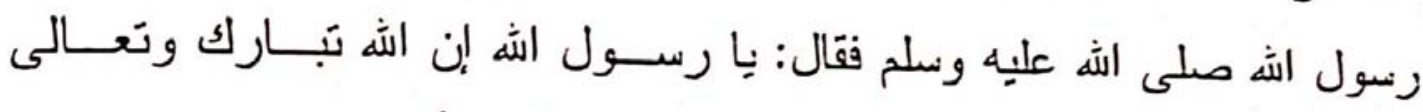

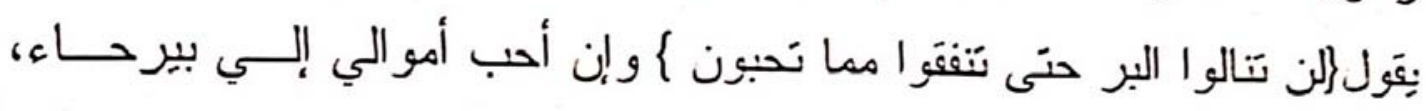

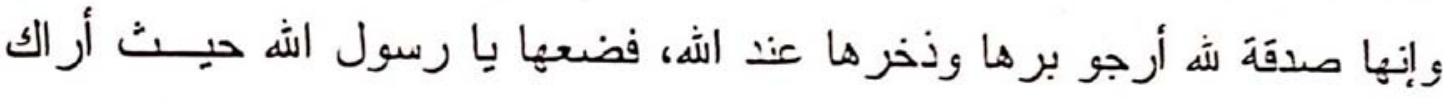

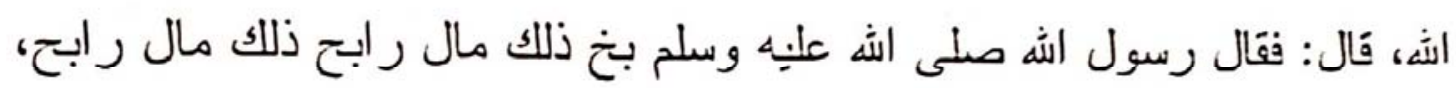

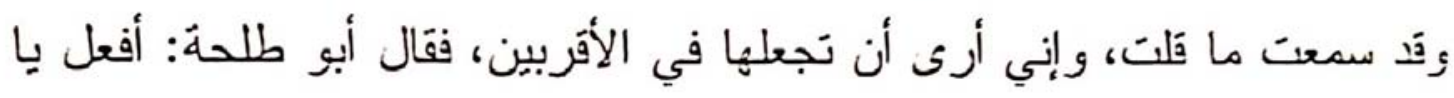

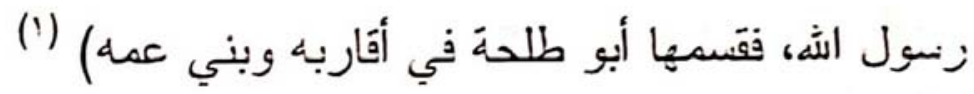

و عند مسلم و الترمذي وغير هما عن أبي هريرة - رضي اله عنـــه ــ أن

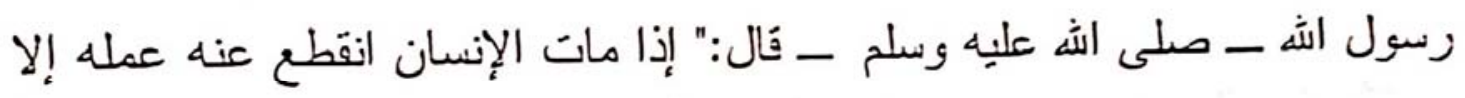

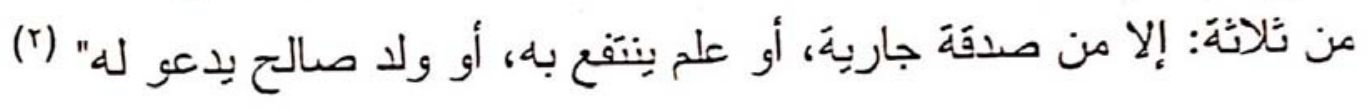

و الصدقَة الجارية محمولة عند العلماء على الوَف، قَال النووي في شرح

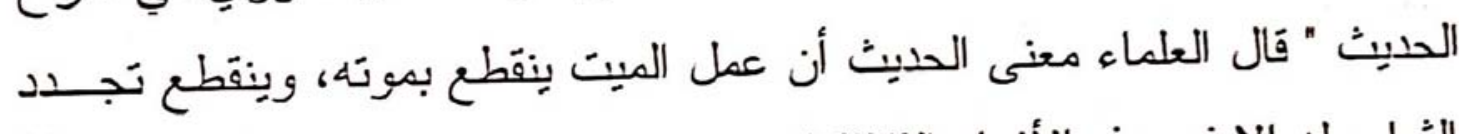

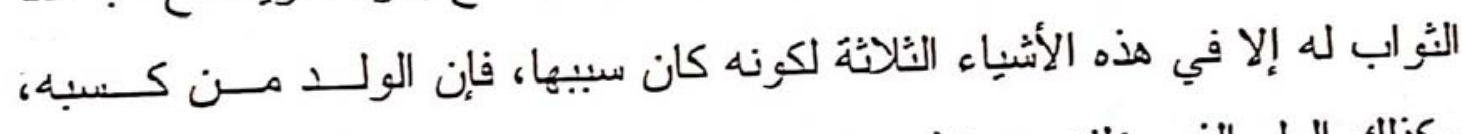

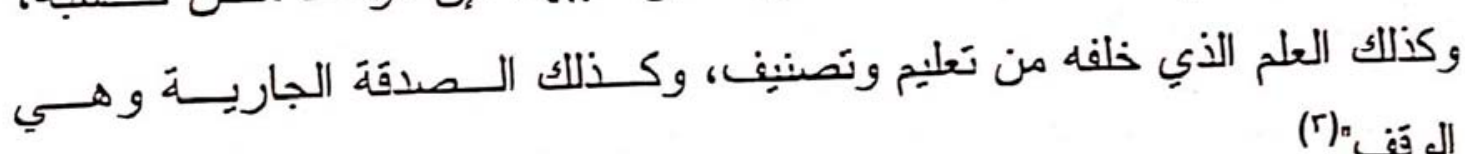

الوقة" (5)

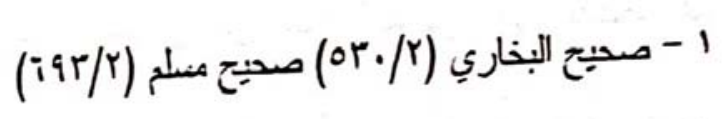

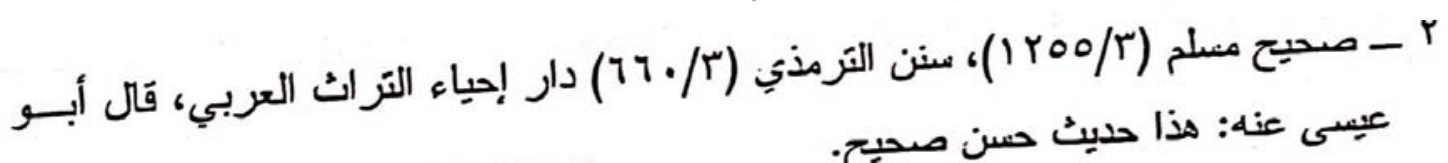

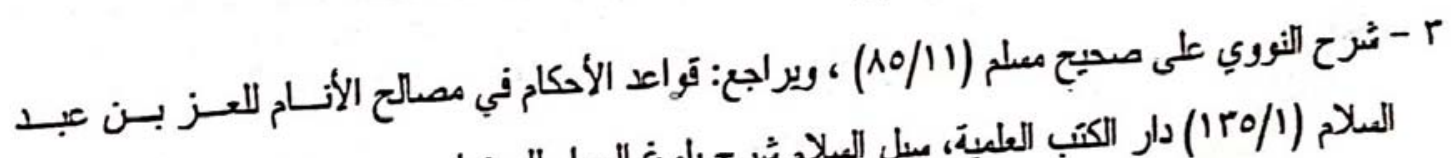

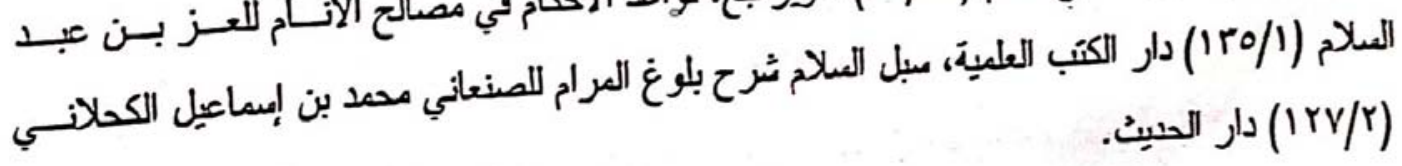

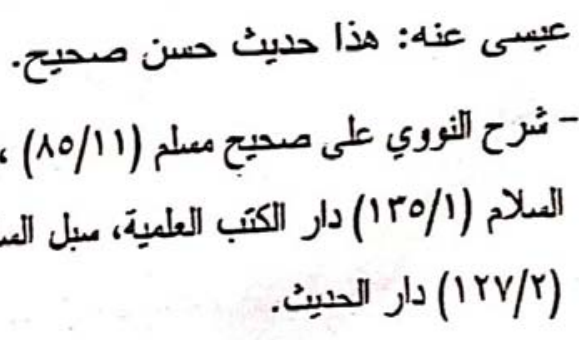


و عند النسائي و الترمذي عن عثمان رضي اله عنه (أن النبــي صــلـى الله

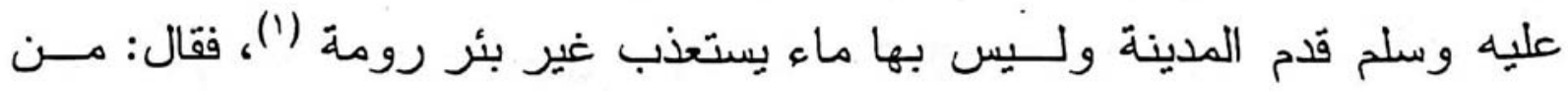

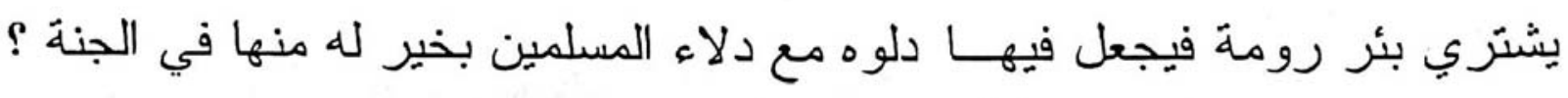

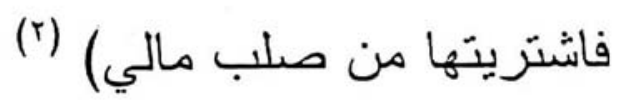

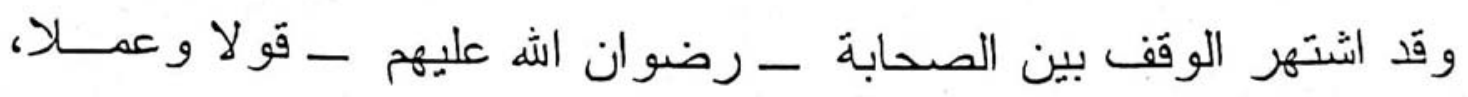
وكذا فيمن بعدهم من التابعين وتابعيهم إلى يومنا هذا من غير نكير .

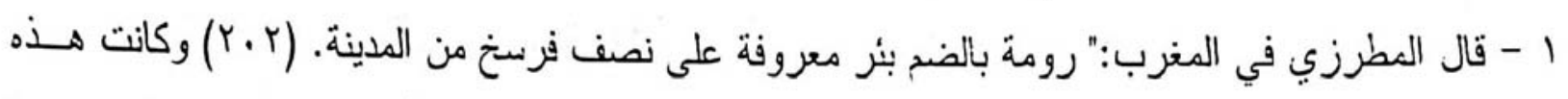

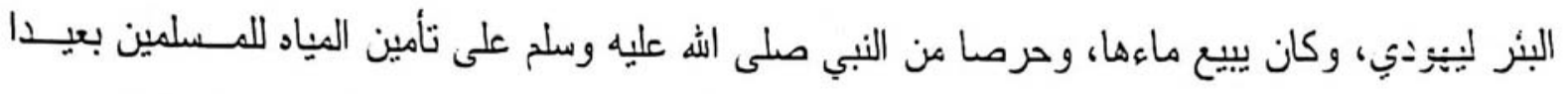

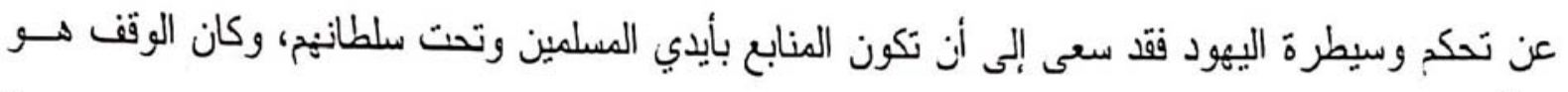

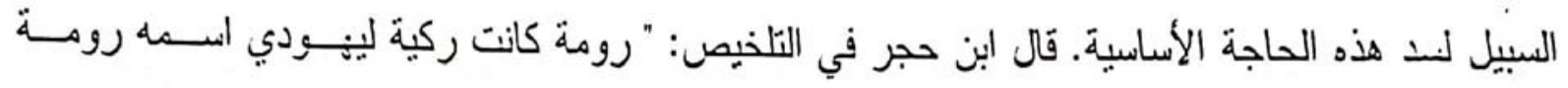

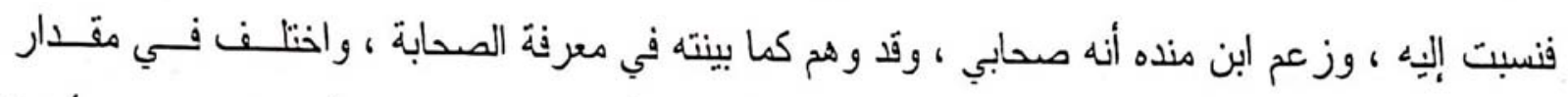

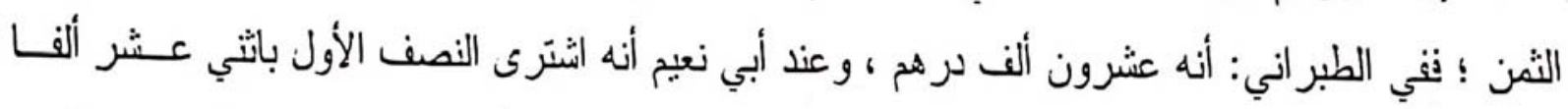

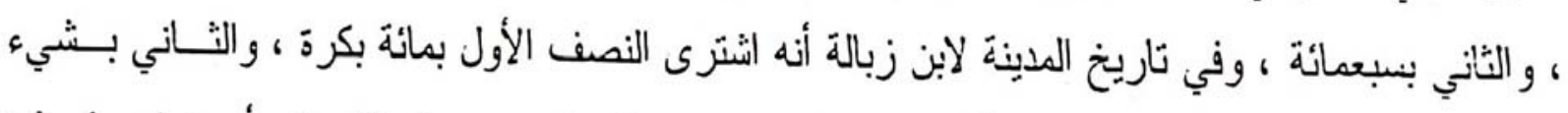

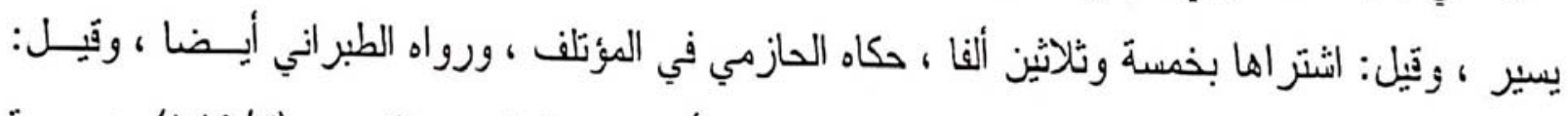

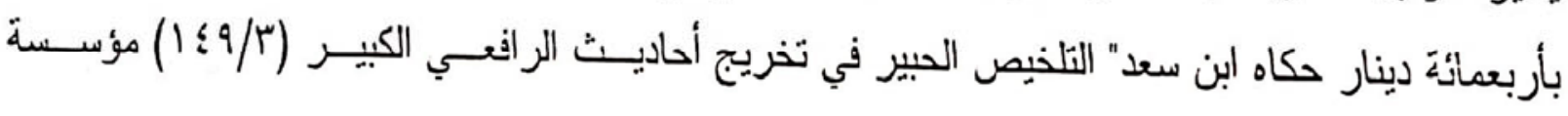

قرطبة.

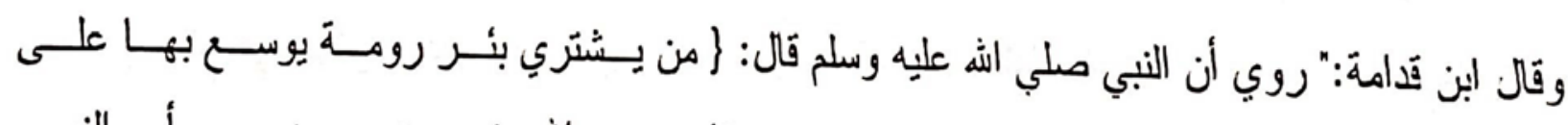

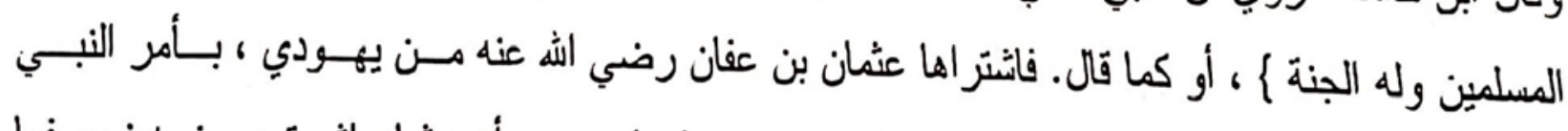

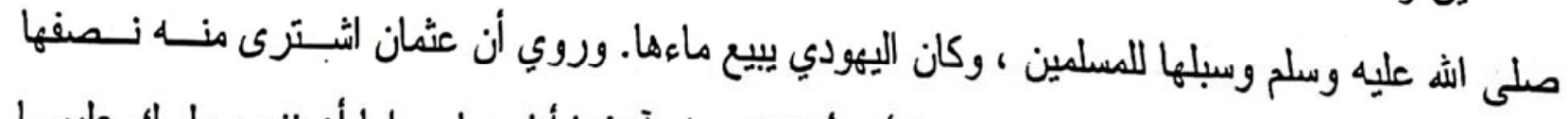

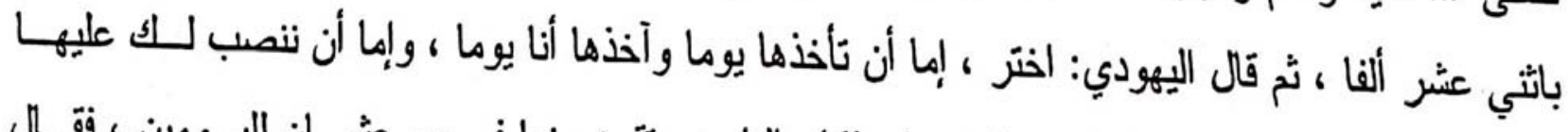

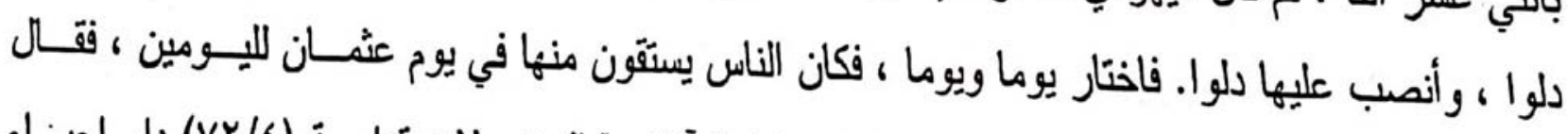

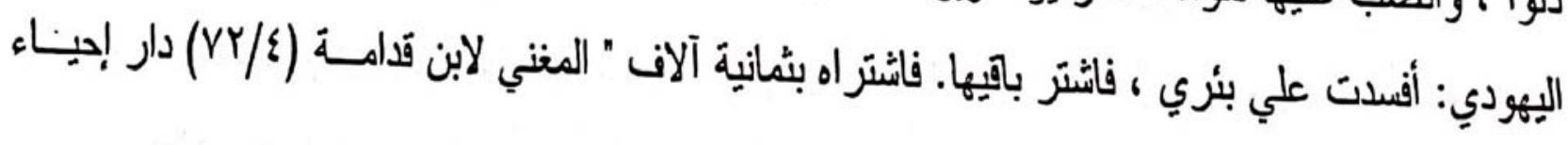
التزاث العربي.

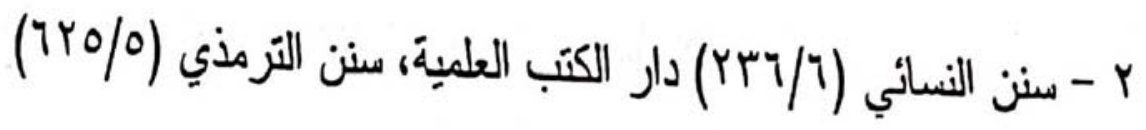


وناز ع في مشروعية الوقف شريح (")، وقال الإمام أحمد: وهذا مذهب أهل

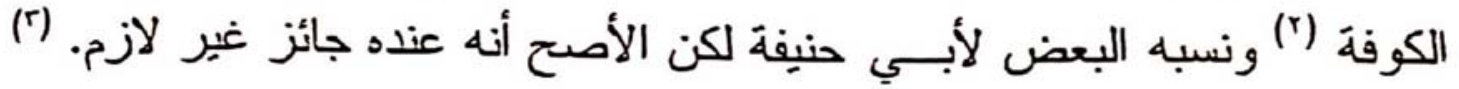

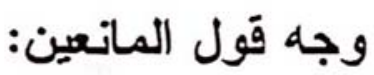

ا- ما رو اه ابن حزم، وابن أبي شيبة في المصنف، و الطحاوي في شرح

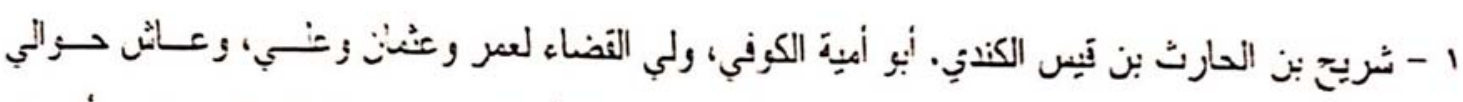

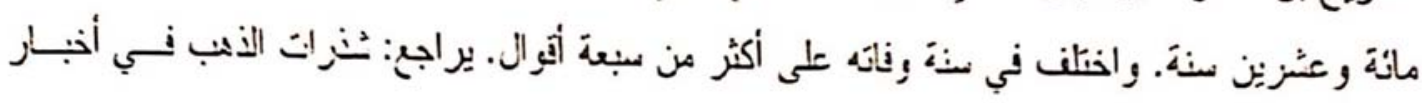

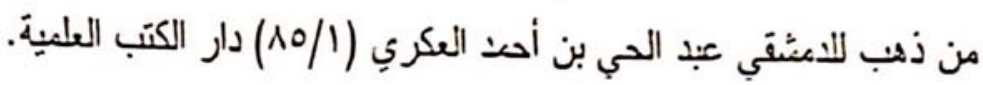

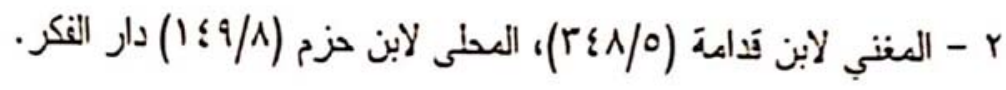

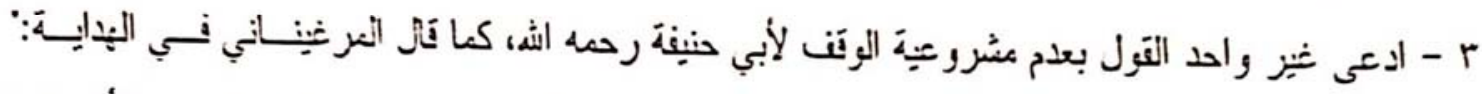

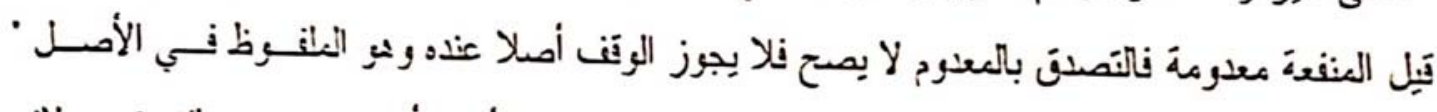

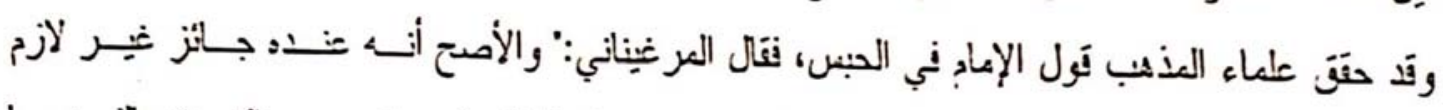

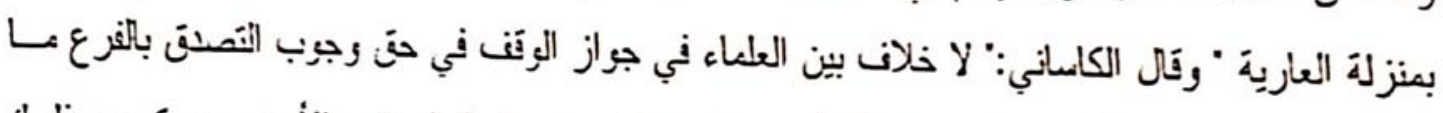

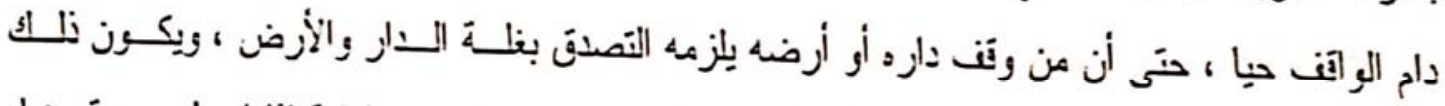

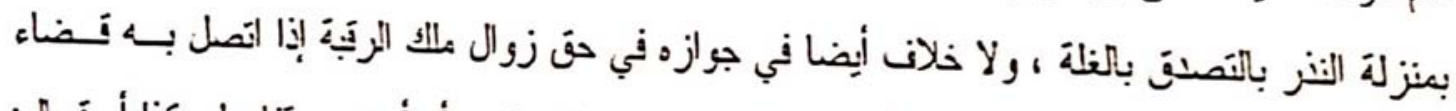

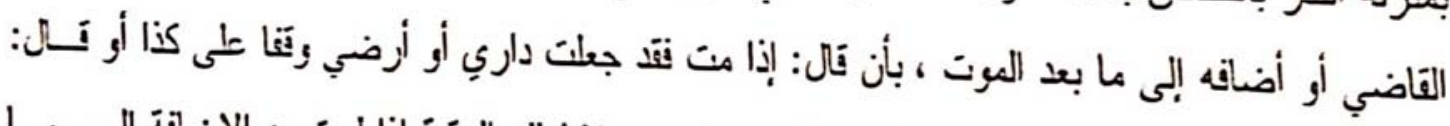

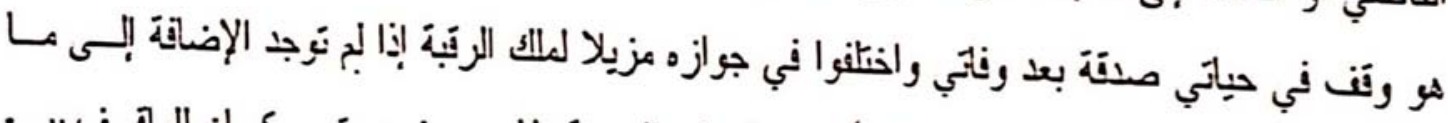

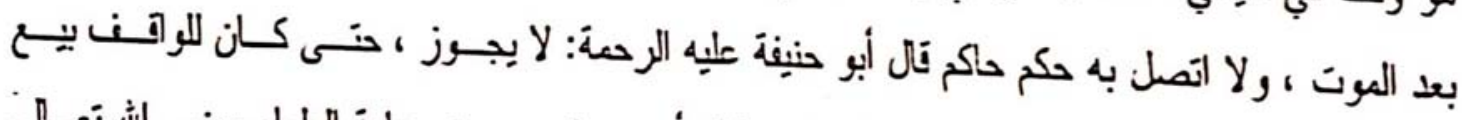

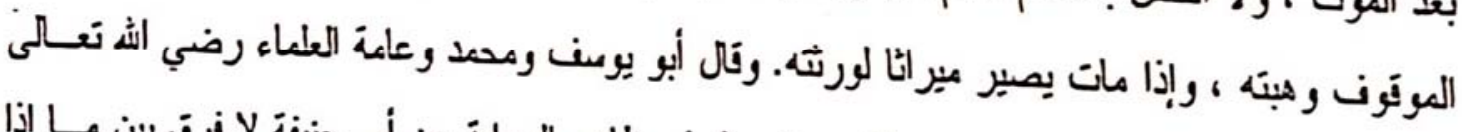

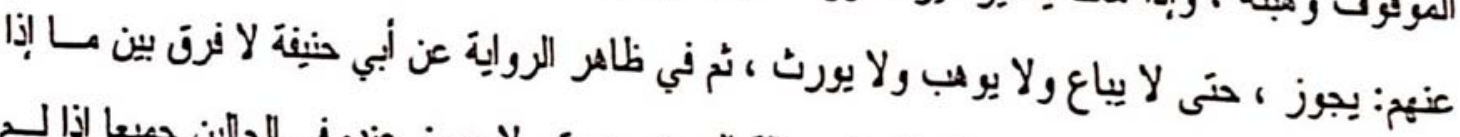

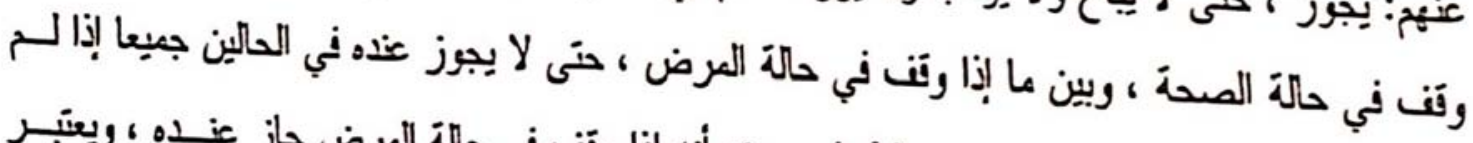

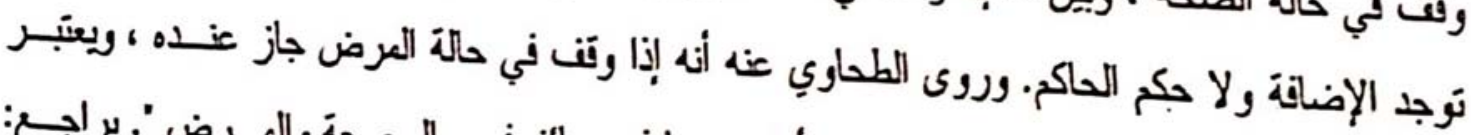

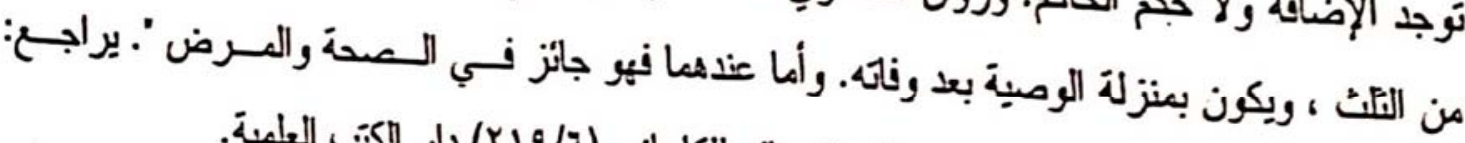

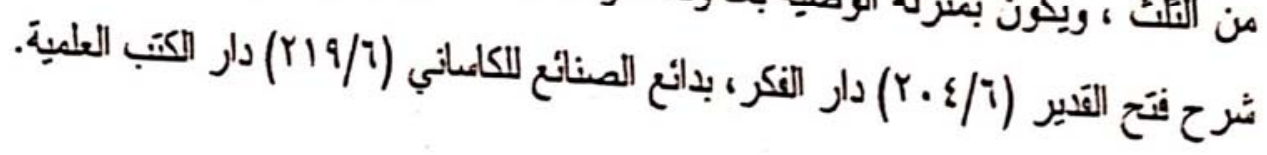


مداني الآتًار : أن شُريحا القاضي قَال: " لا حبس عن فر ائض اله " (")، و عند ابن

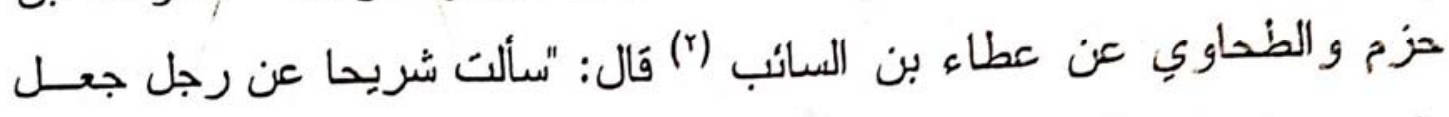

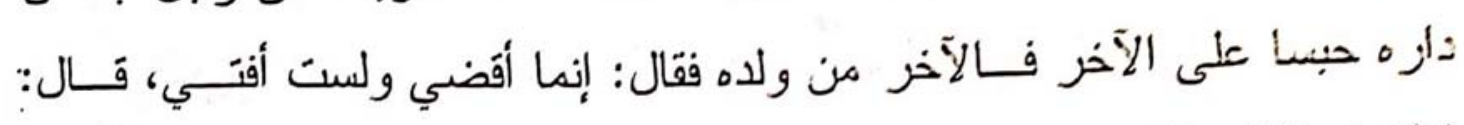
فُنانشدنَه فتلال: لا حبس على فز ائض اله ". قَال الطحاوي:" وهذا لا بِسع القضاة جعله ولا يسع الأئمة تقليد من يجهل

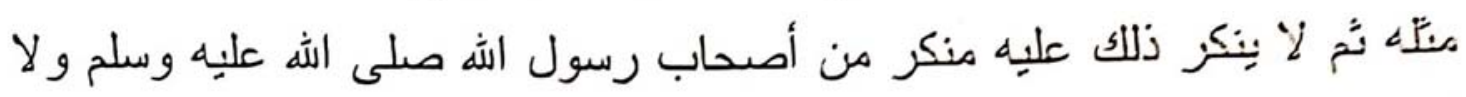

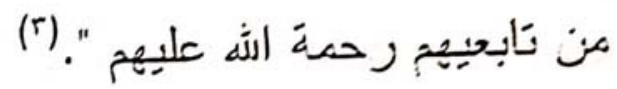
و عند ابن أبي شيبةَ عن الشنبي (؛) قَال: قَال علي رضي اله عنه لا حبس

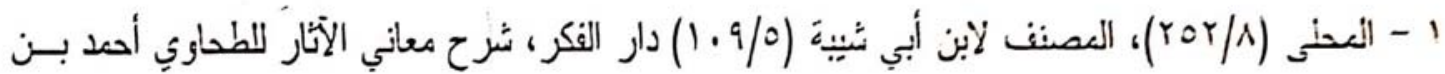

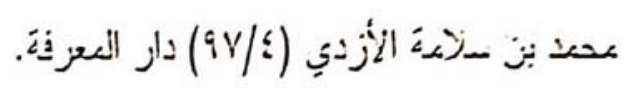

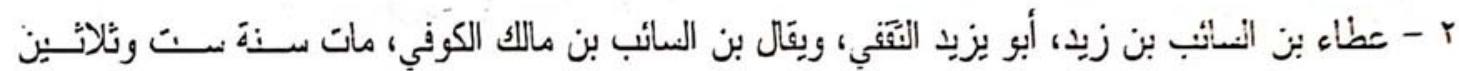

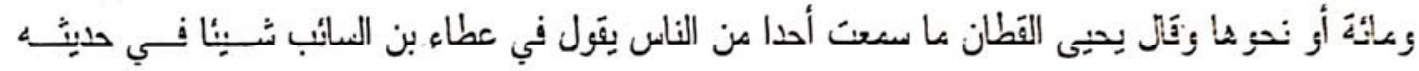

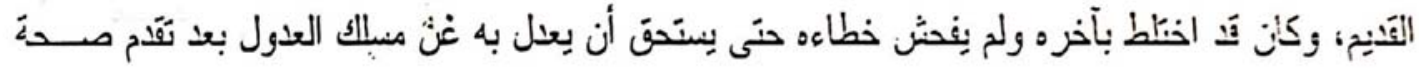

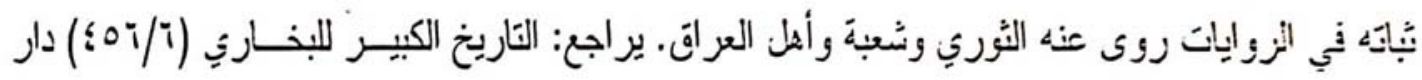

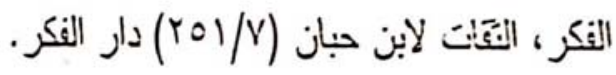

$$
\text { r - تشرح معانتي الآثار - هوضع سابق. }
$$

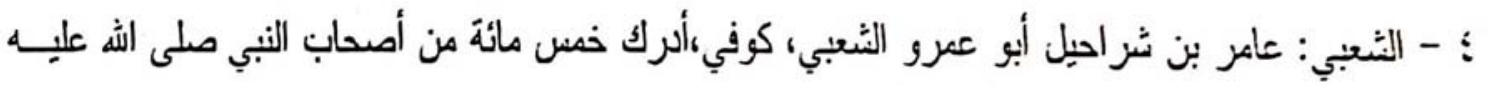

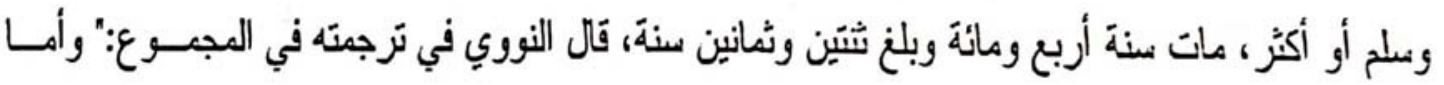

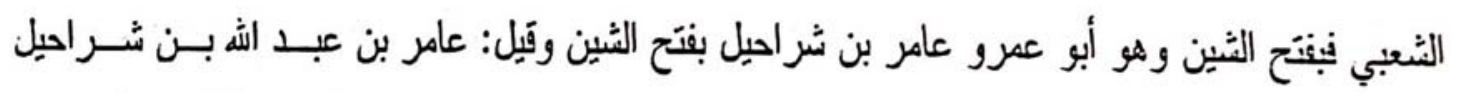
الكوفي التابعي الكبير المنقق على جلالته وإمامته وبر اعته وشُدة حفظه ، روينا عنه قال: أركت خمسيمائة من أصداب رسول اله صلى الله عليه وسلم وروينا عنه قَال: (ما كتبت سوداء في بيضاء قَط ، ولا حسلشي

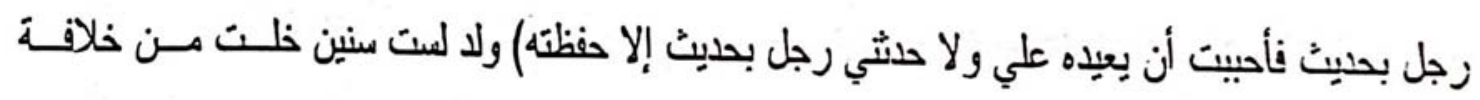

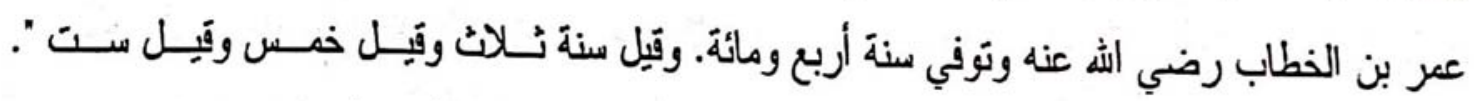

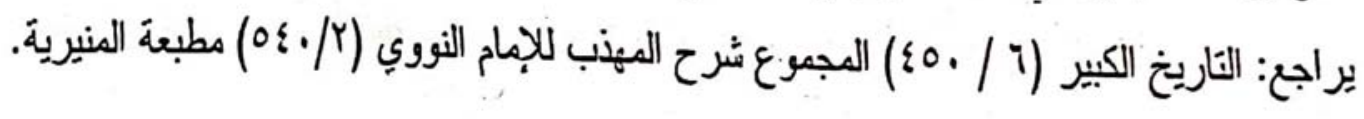




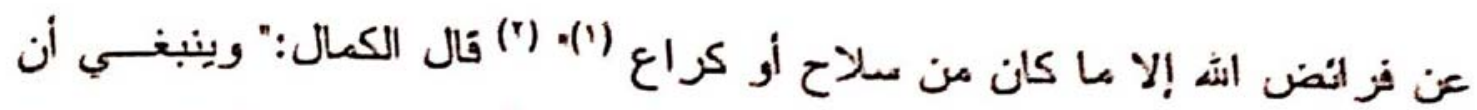

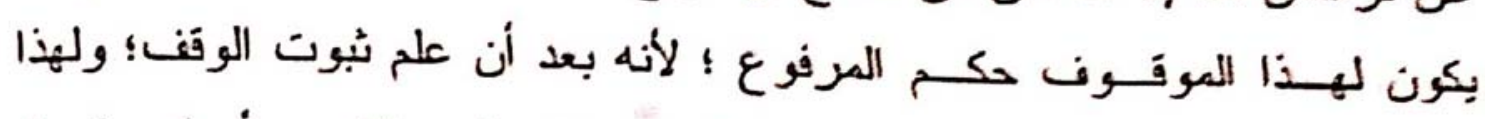

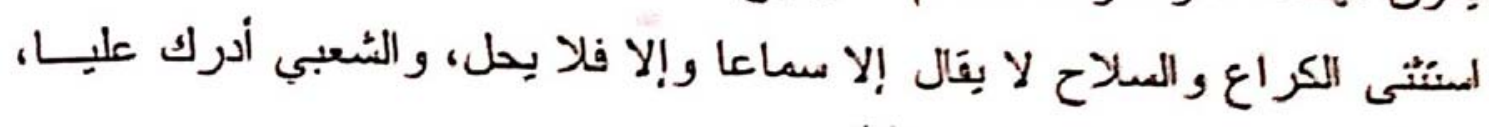

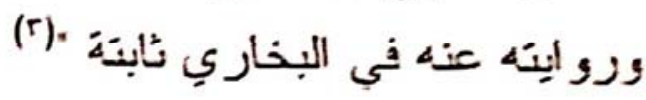

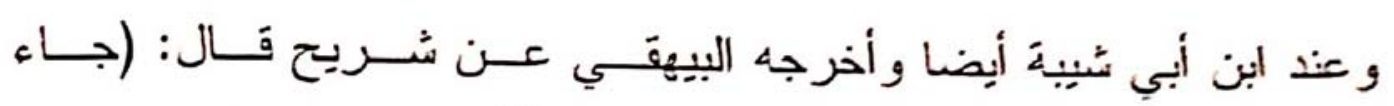

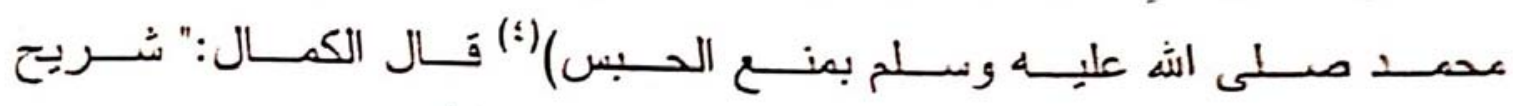

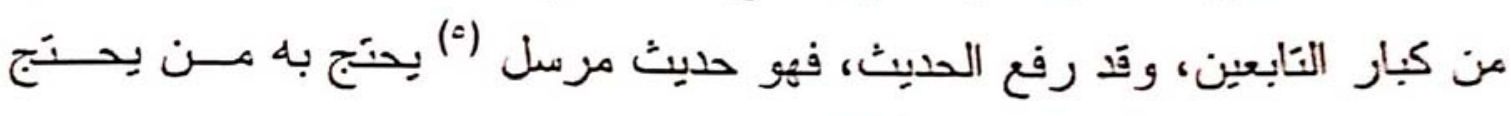

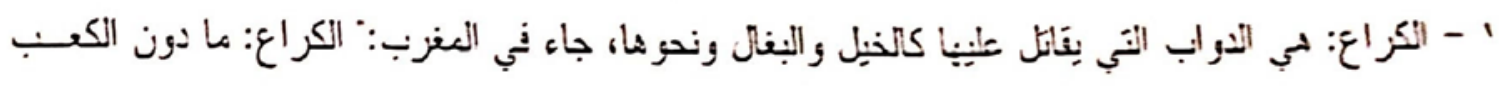

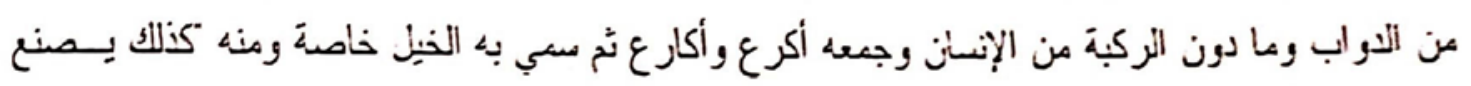

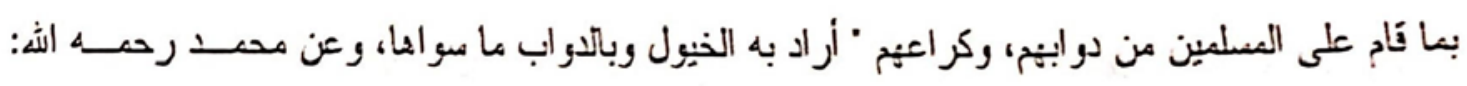

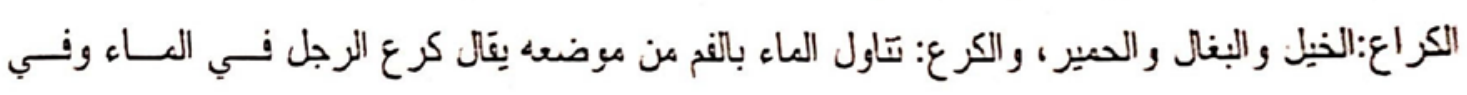

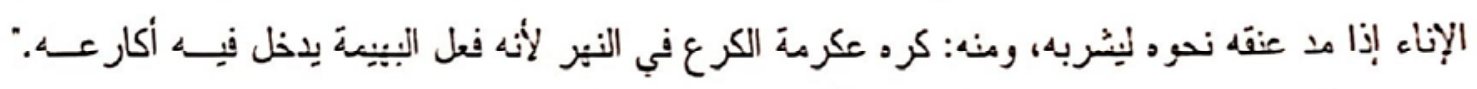

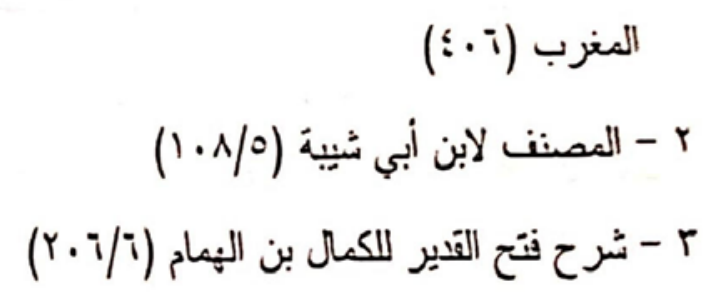

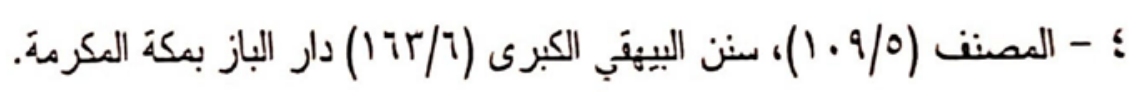

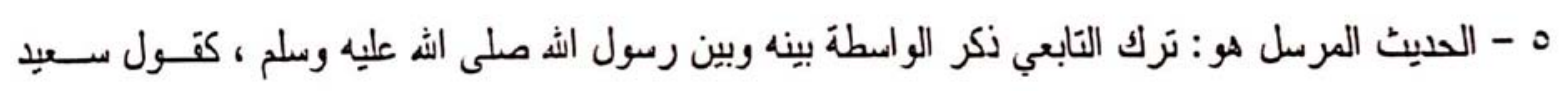

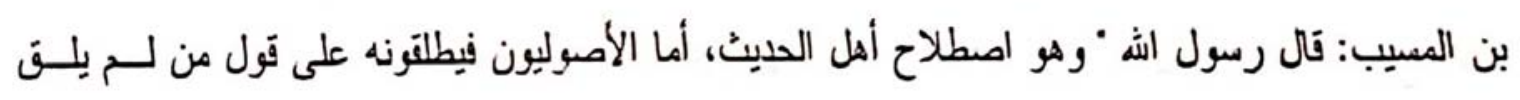

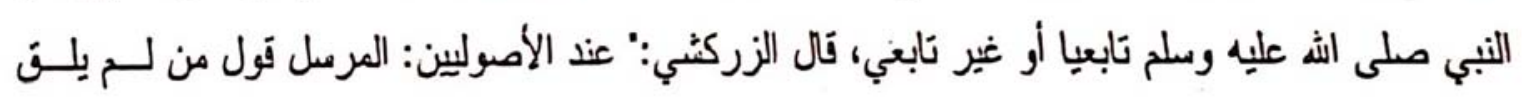

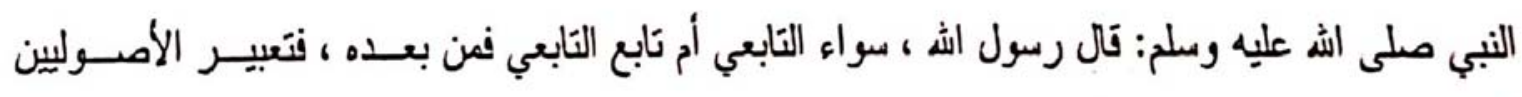

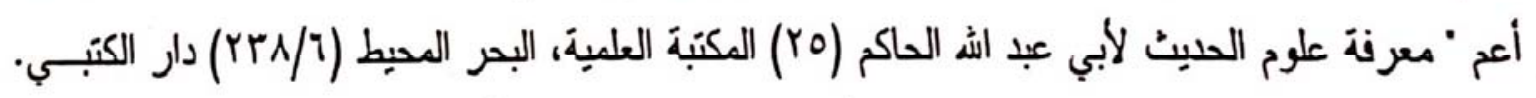

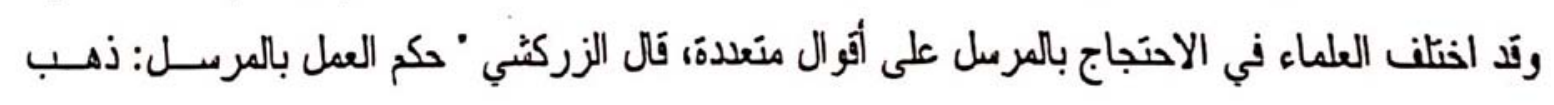

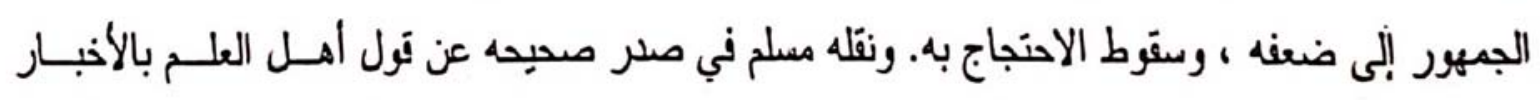

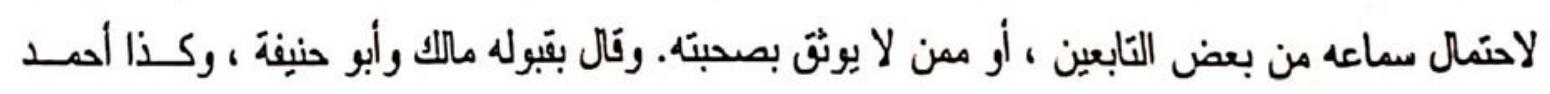

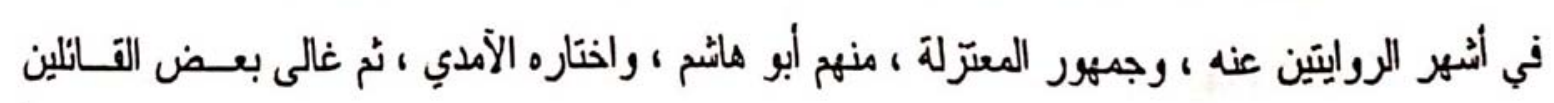




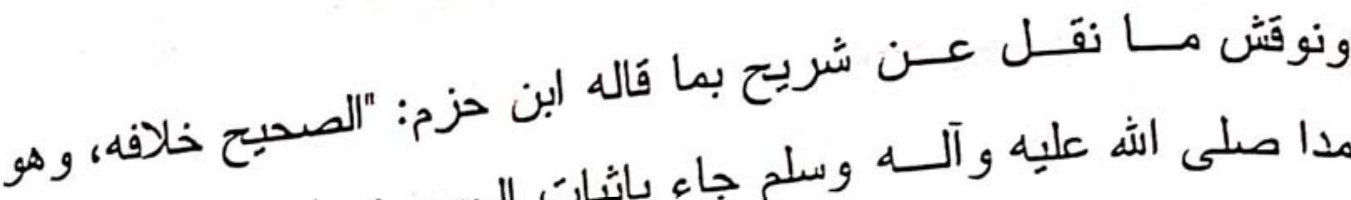

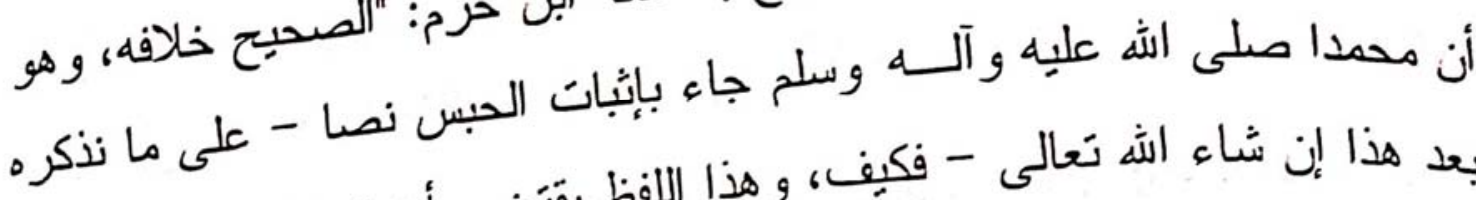

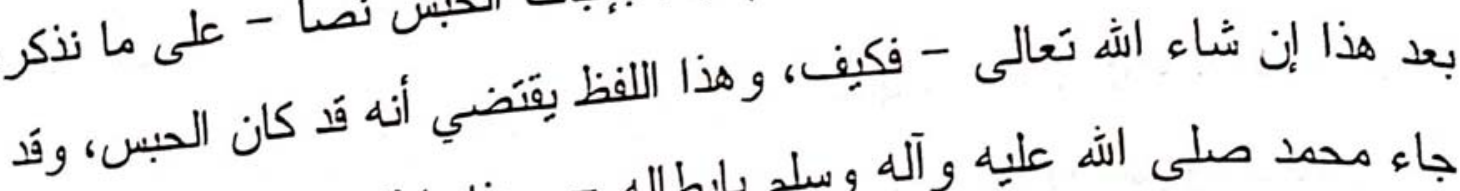

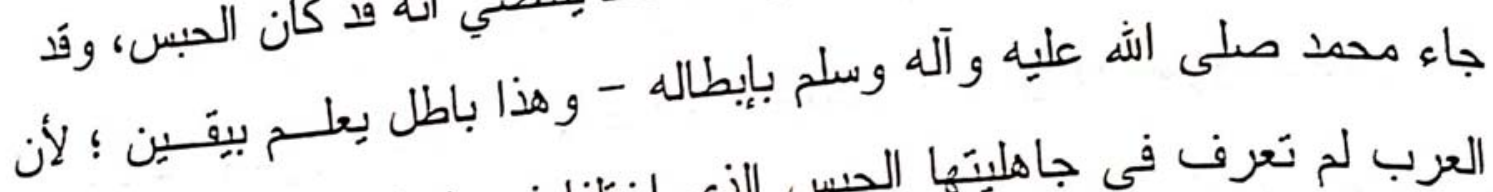

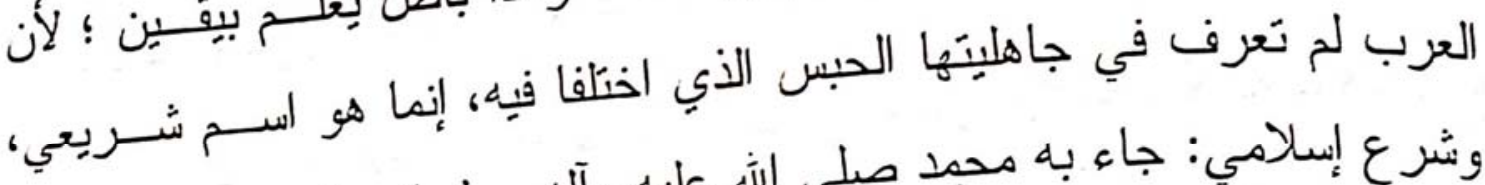

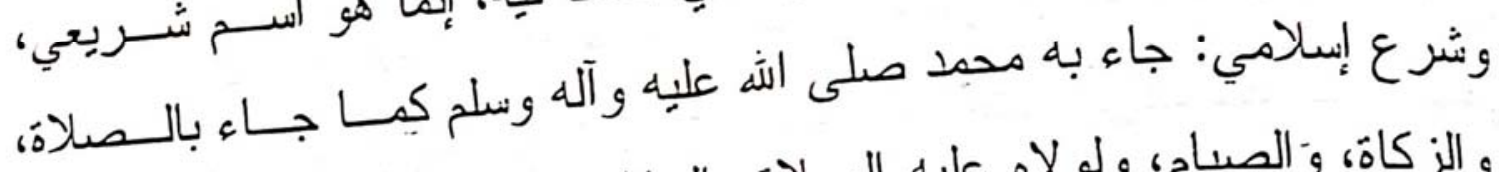

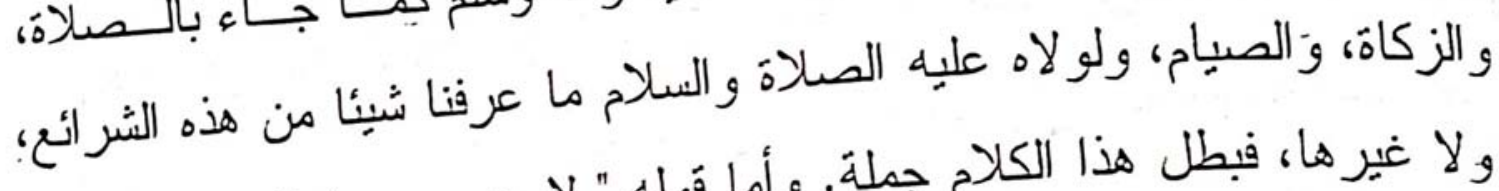

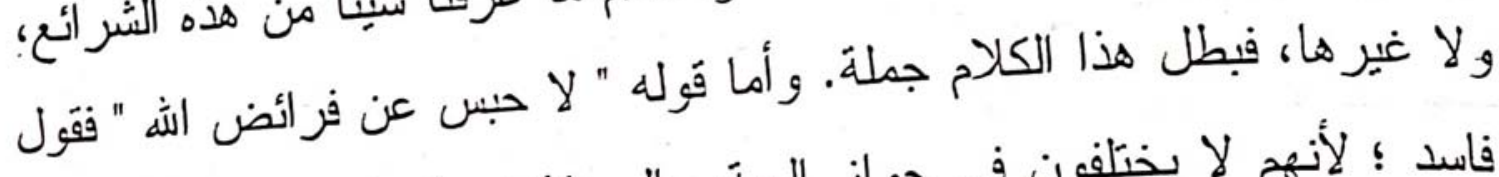

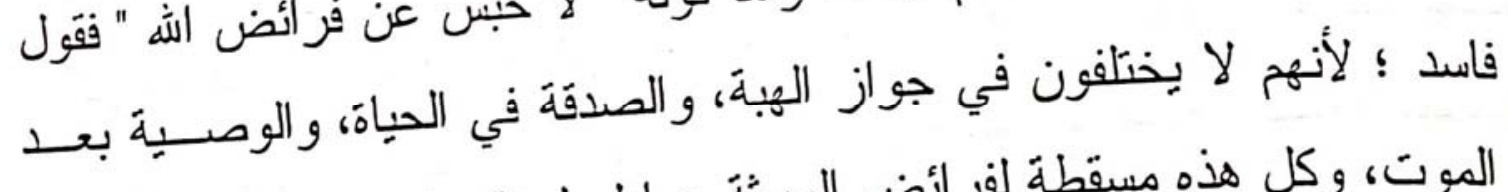

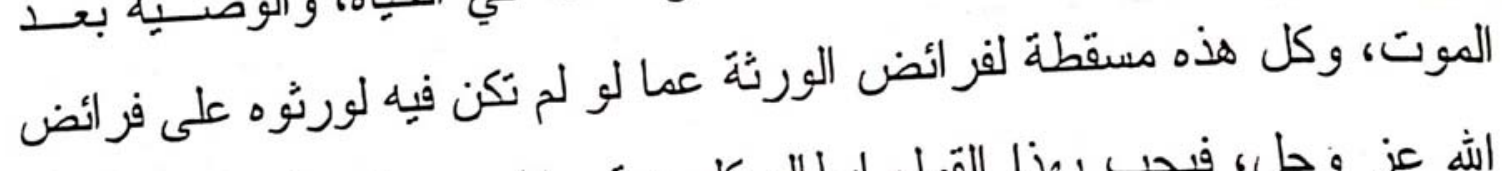

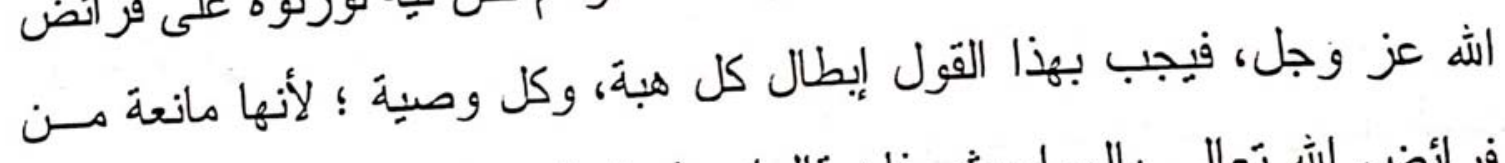

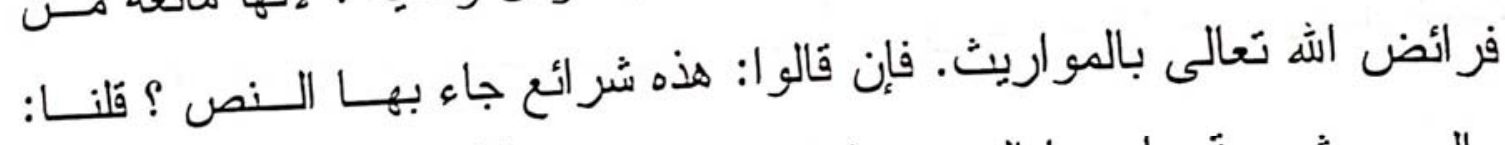

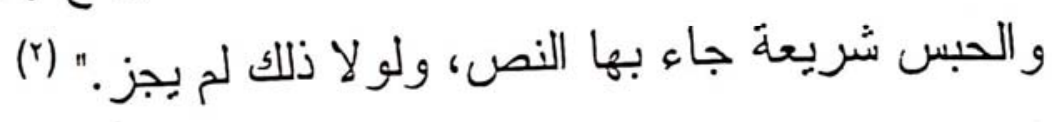

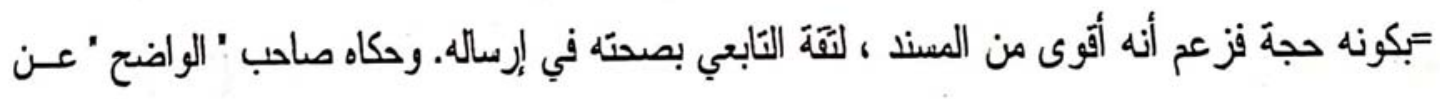

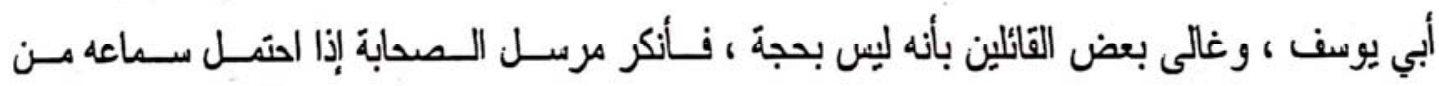

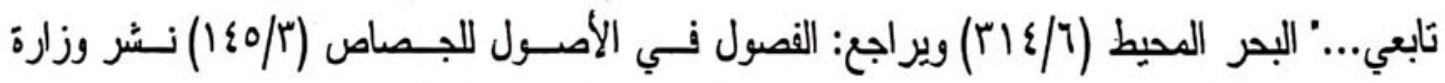
الأوقان الكويتية - الطبعة الثانية، المستصفى لأبي حامد التزالي (عَا) دار الكتب العلية.

$$
\begin{aligned}
& 1 \text { - شرح فتح القَير - مرجع سابق. } \\
& \text { r }
\end{aligned}
$$




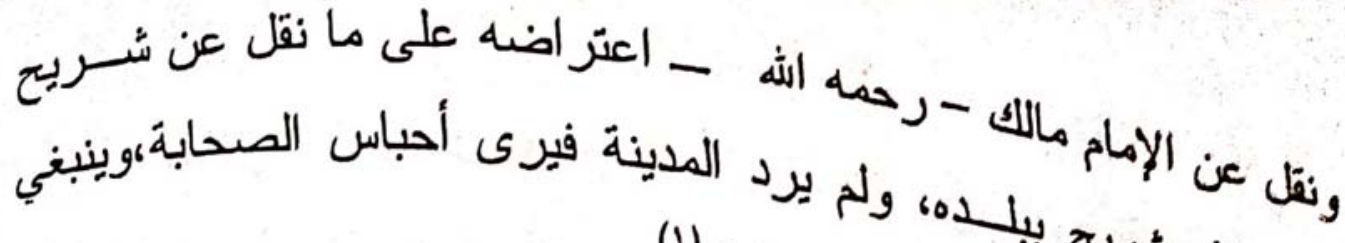

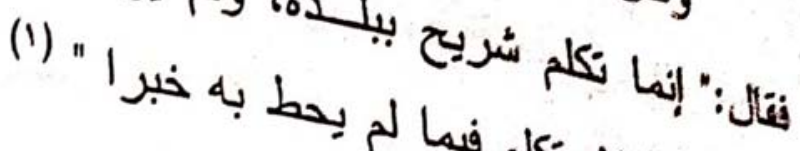

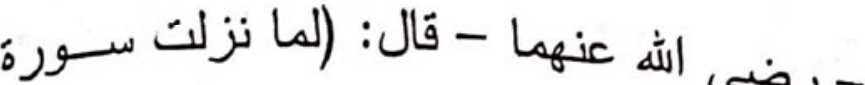

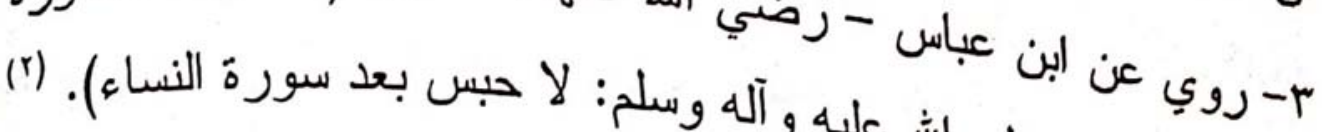

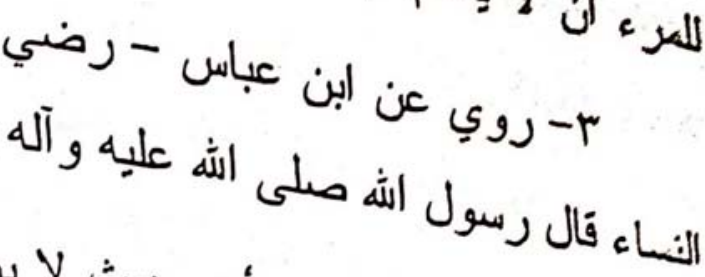

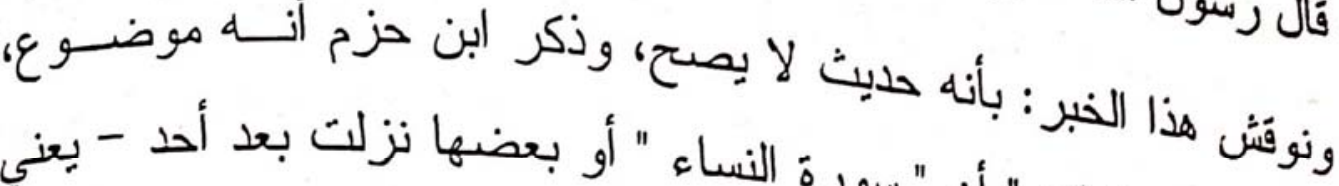

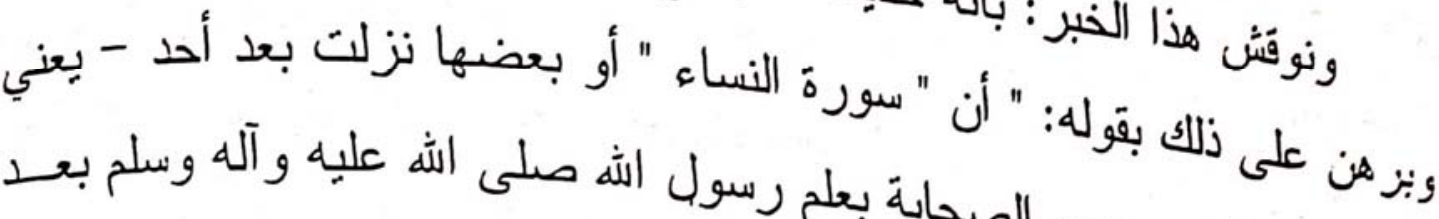

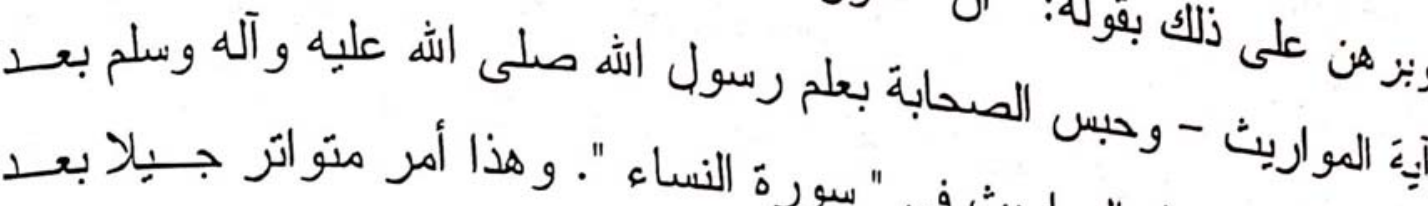

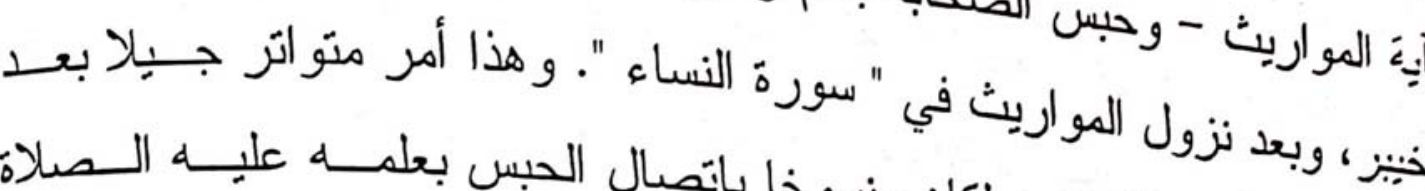

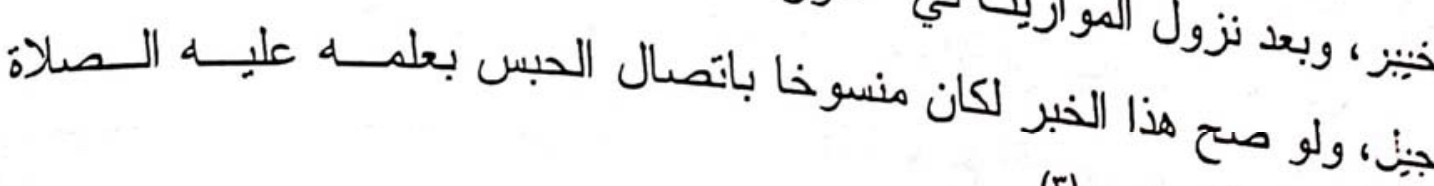

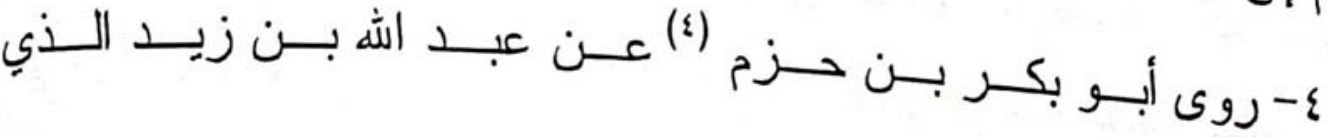

$$
\text { والنِلام إلى أن مات". (ت) }
$$

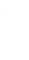




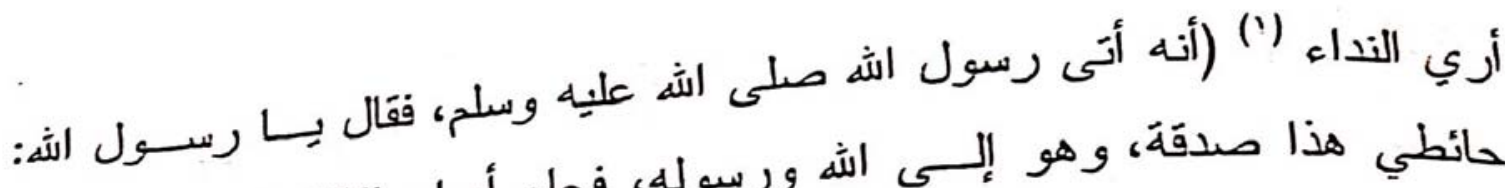

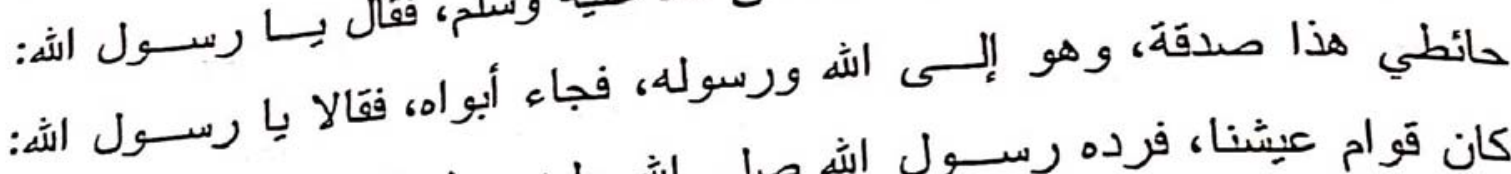

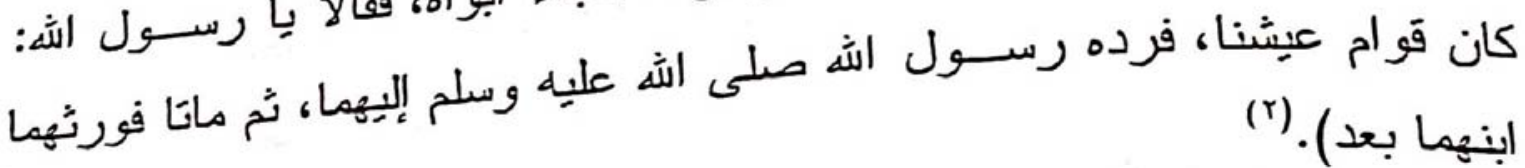

ونوقَش هذا: بأنه لا حجة فيه من وجوه: أولها: أنه منقطع (r) ؛ لأن أبــا

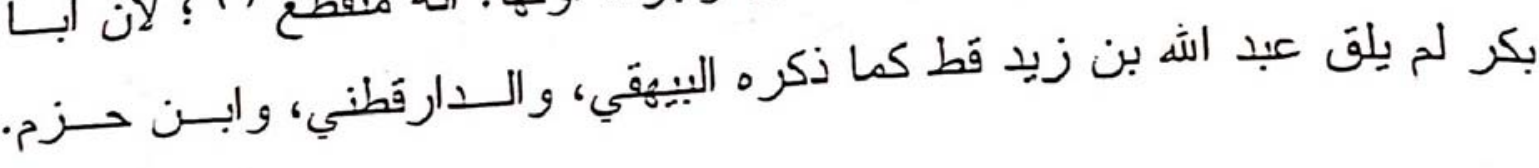

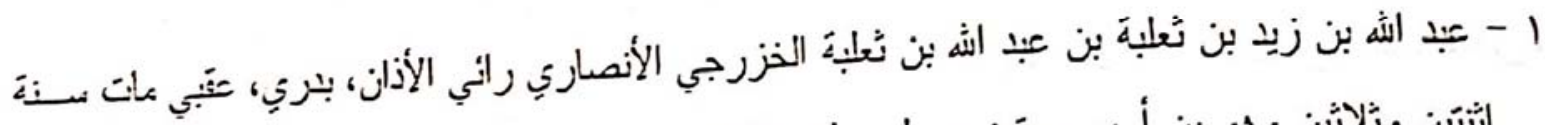

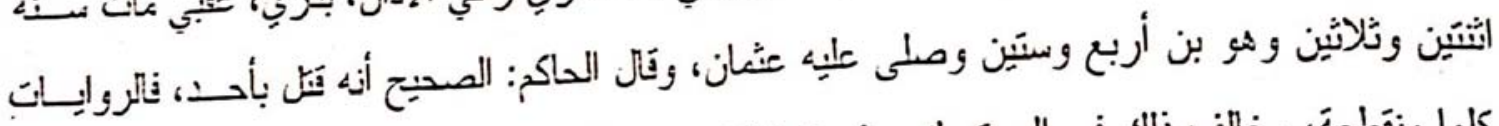

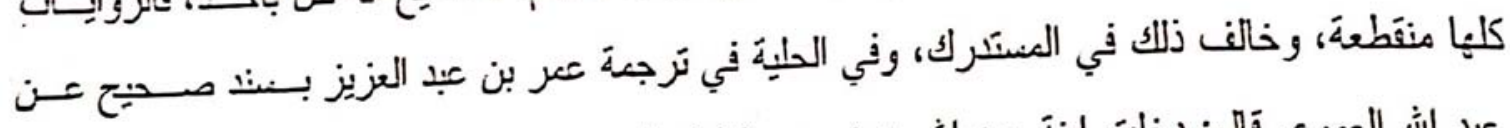

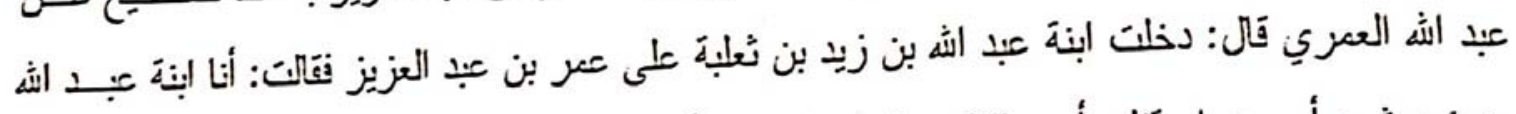

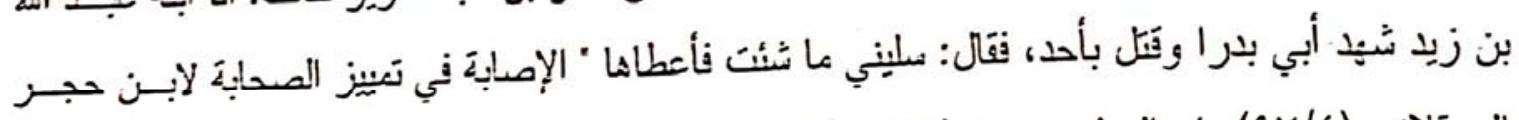

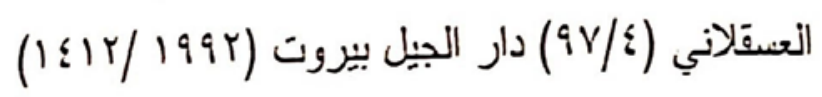

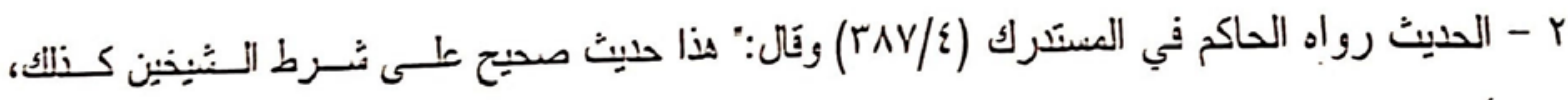

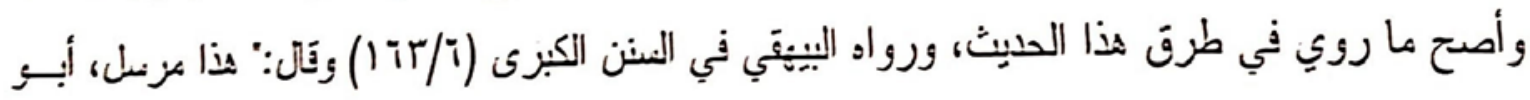

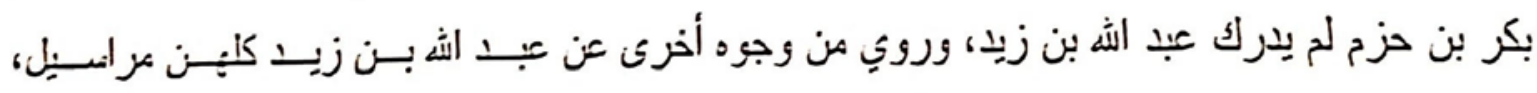

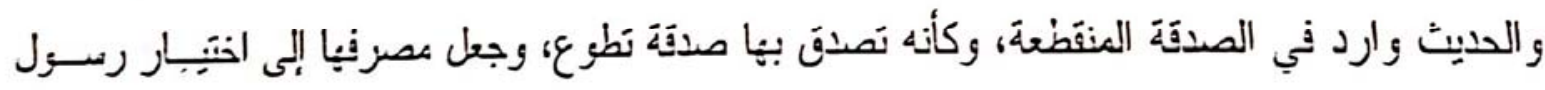

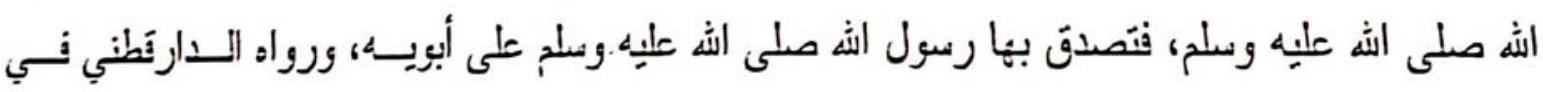

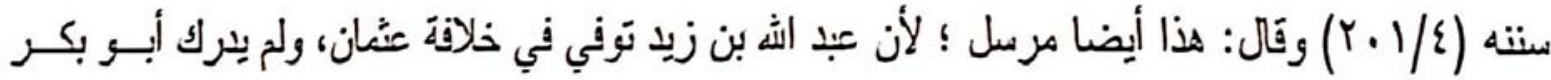
بن حزم.

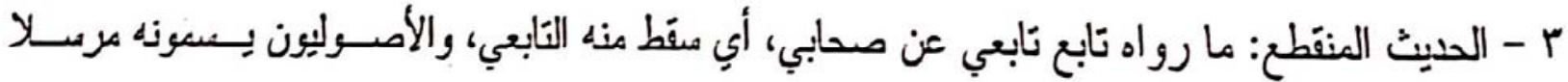

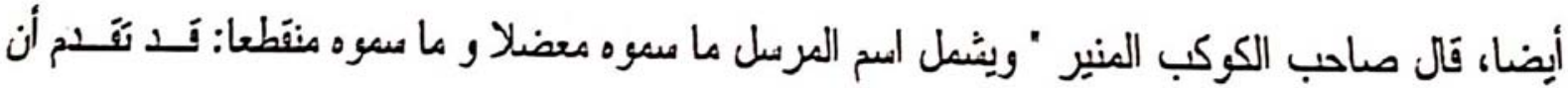
أهل الحليث سموا ما رواه تابع التابعي وما سقط بين راوييه أكثر بن واحد معضلا. وقال القاضــي وكثيـر

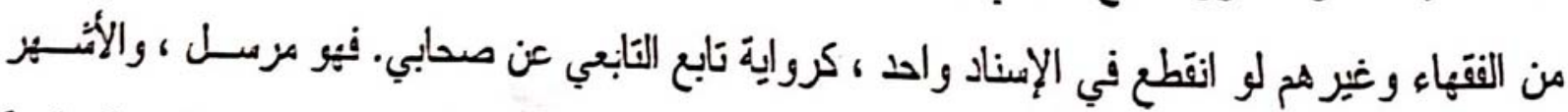

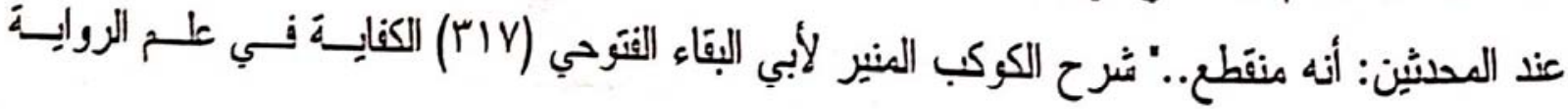
للفطيب البغادي (YlY) المكتبة العلميَة. 


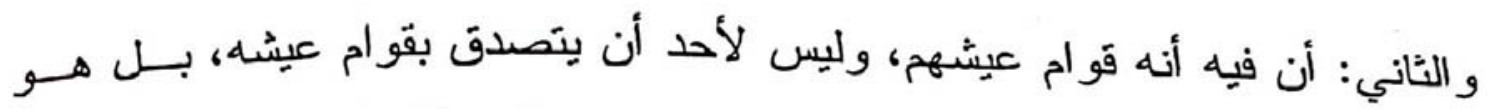

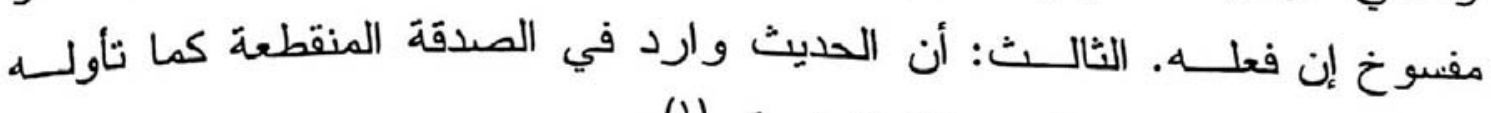

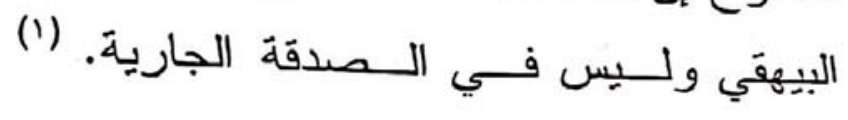

0- أن الوقف يخرج المال من مالكه إلى غير مالك،، وهذا باطل.

ونوقش هذا: بأن الوقف ليس إخراجا إلى غير مالك، بـلـل إلـى ملـــك اله اله

تَعالى، وهو أجل مالك.

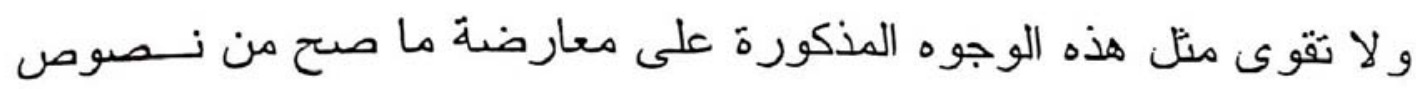

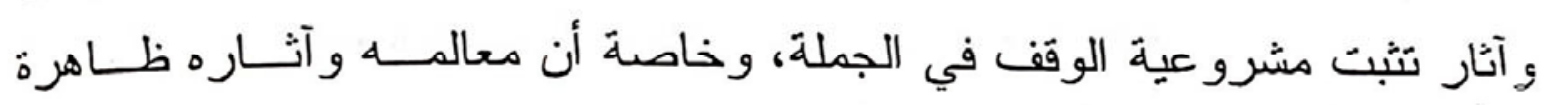

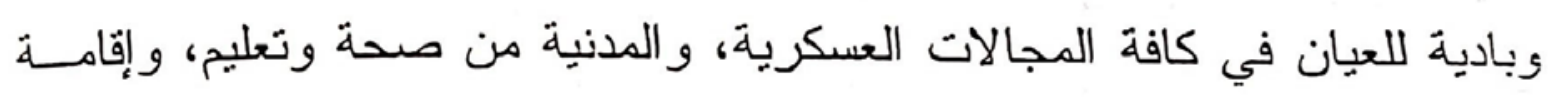
جسور وطرق، و غير ذللك مما لا ينكره أحد.

1 - ير اجع: المحلى موضع سابق، السنن الكبرى اللبيهقي - موضع سابق، سنن الدارتطني - موضع سابق. 


\section{المبحث الأول}

\section{التُعريف بالمنافع}

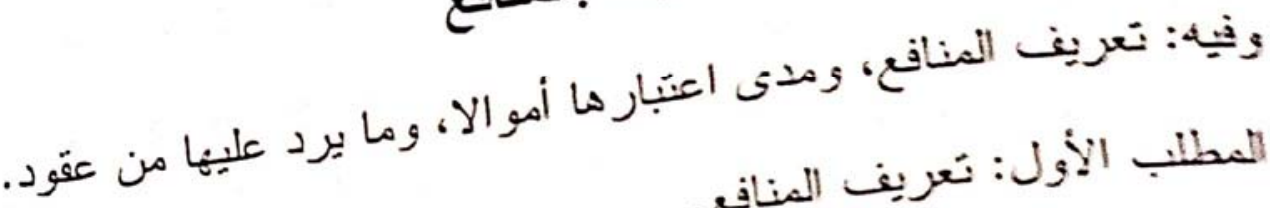
المطلاب الأول: نَعريف المنافع.

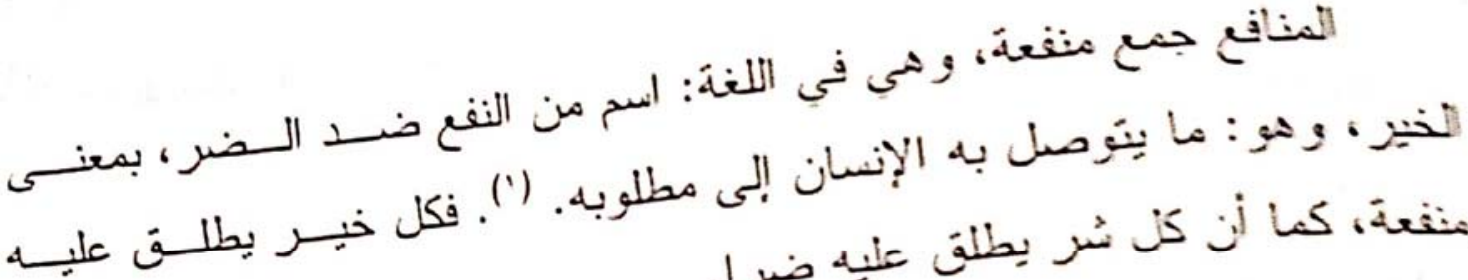

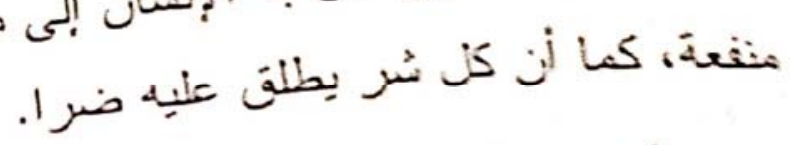

أما منفعة النشي،، في ما تجنى منه، سواء أكانت تلك المنفعة عينية كاللبن

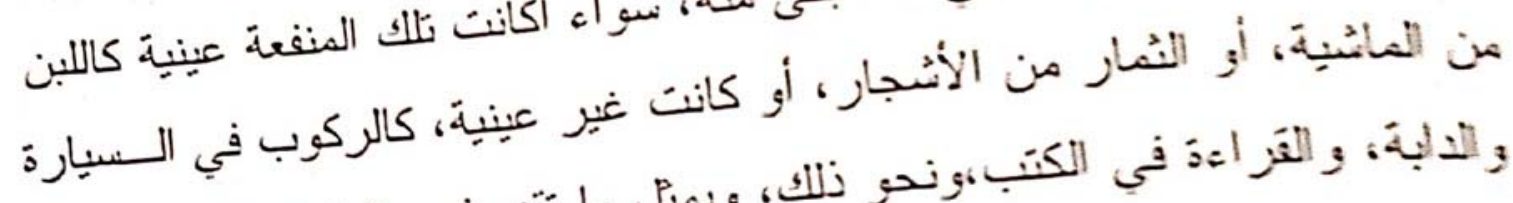

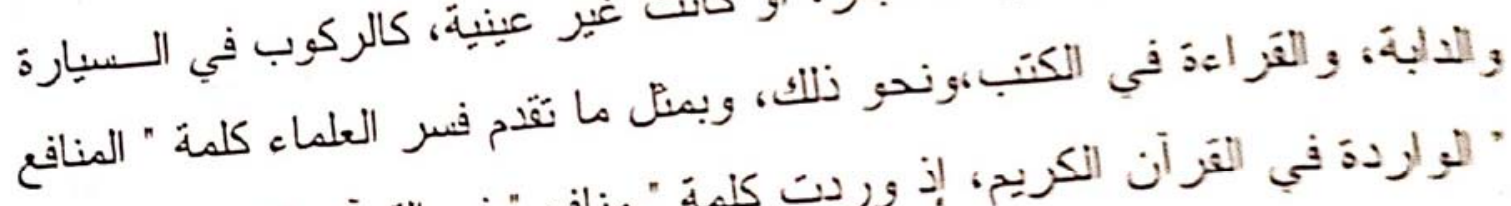

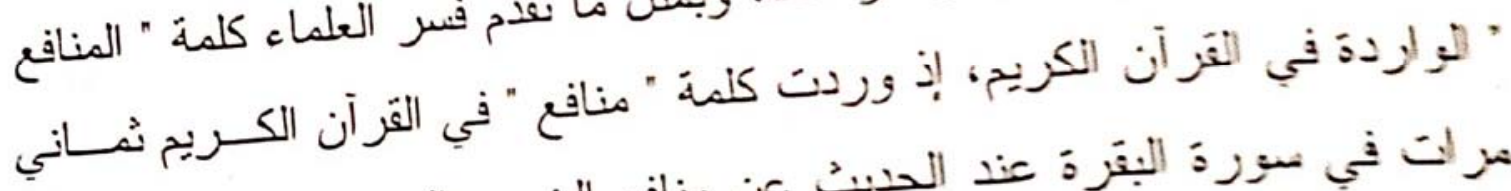

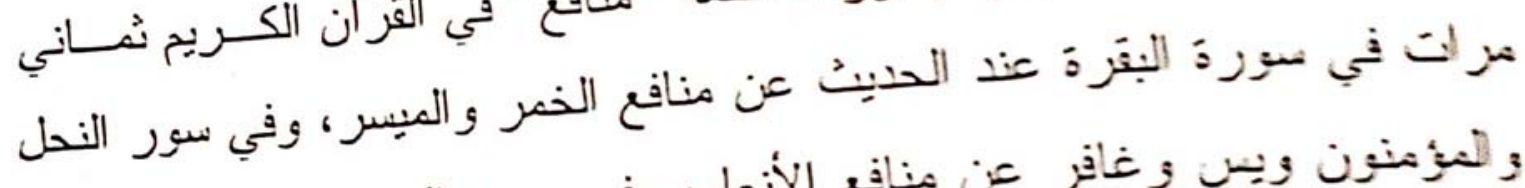

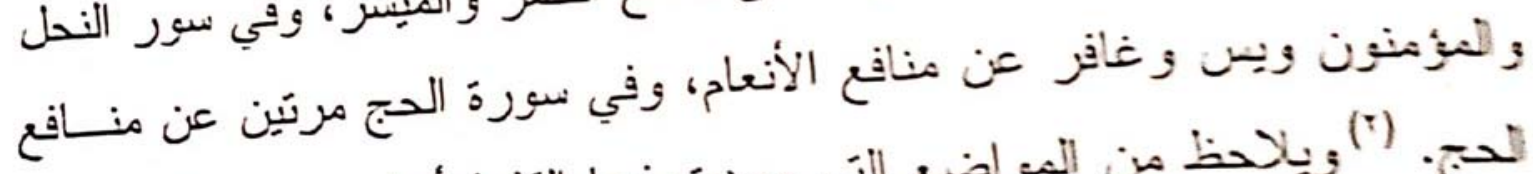

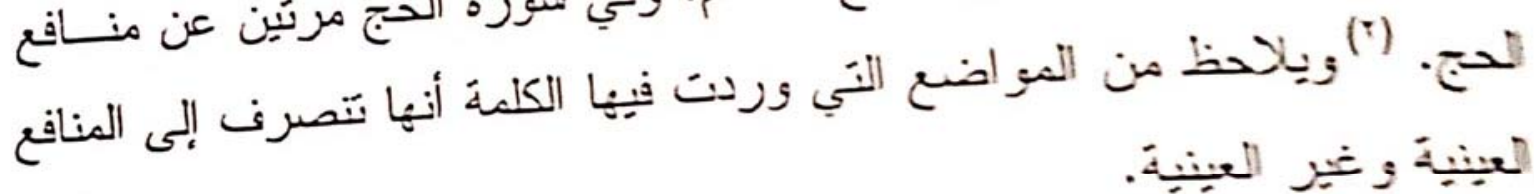
العينية وغير العبينة.

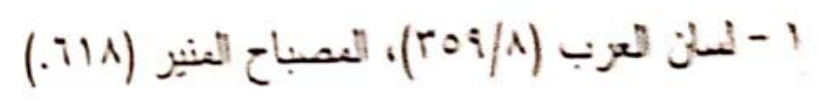

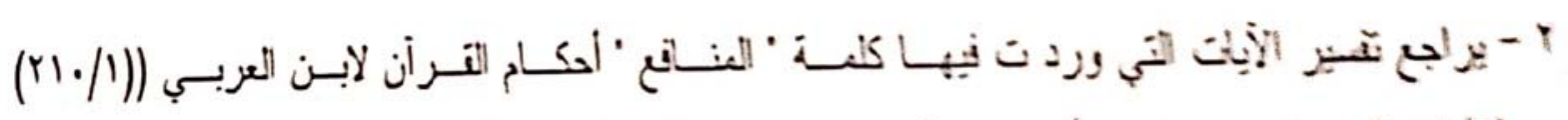

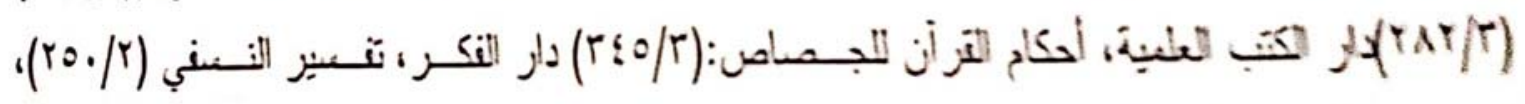

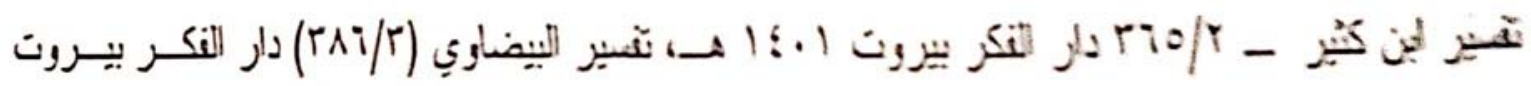

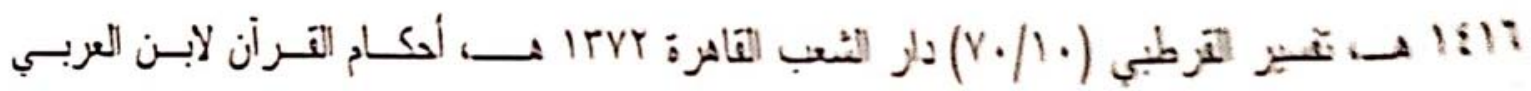


وقد ذهب بعض الفقهاء إلى أن مصطلح" المنافع "لا يراد به مطلق منفعة،

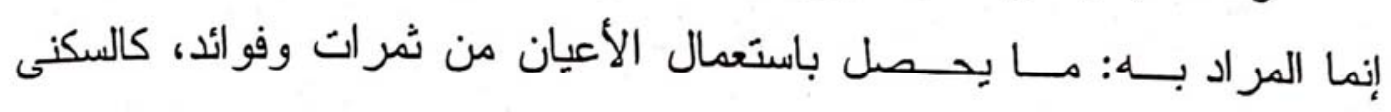

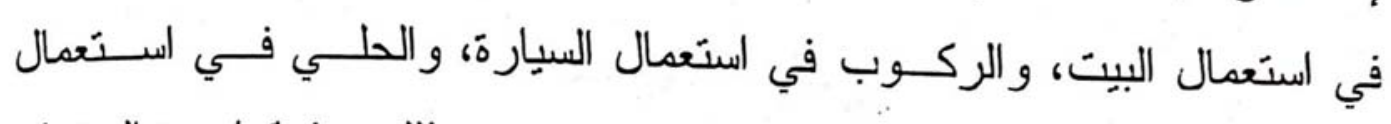
الزينة، و اللبس في الثياب، و القر اءة في الكتب، ونحو ذلك، ولكي، وفرقوا بين المنفعة

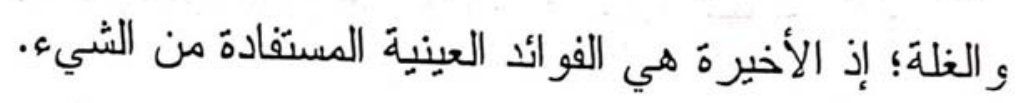

وقَ ضبطها بعضهم بناء على ذلك بأنها: " ما تملك بالإجارة " (1)

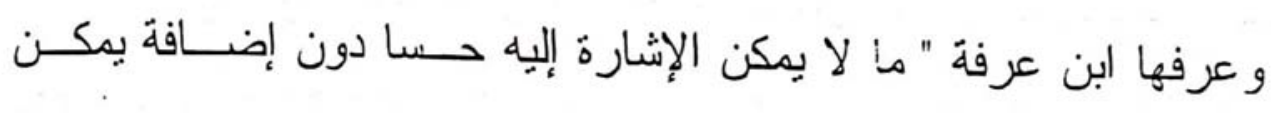

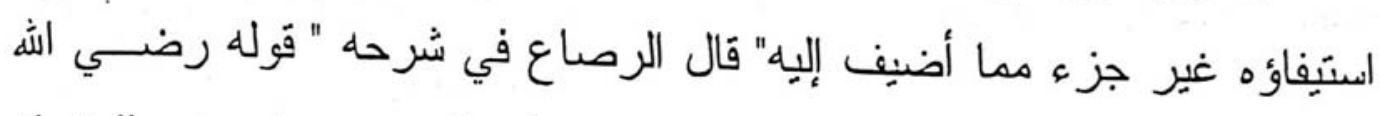

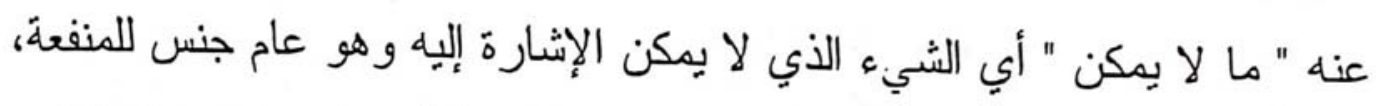

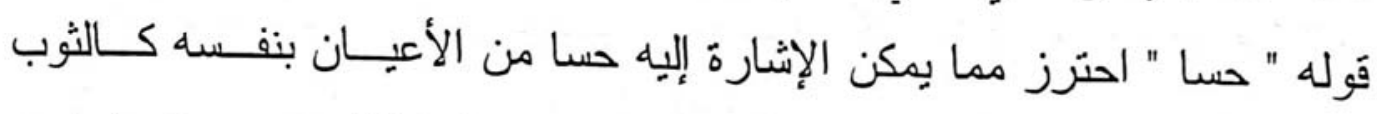

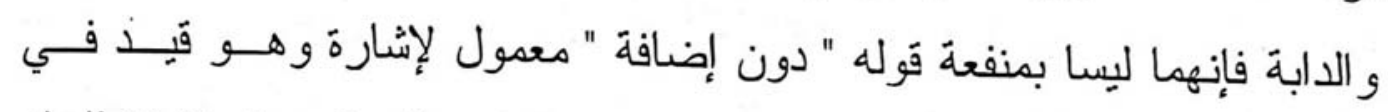

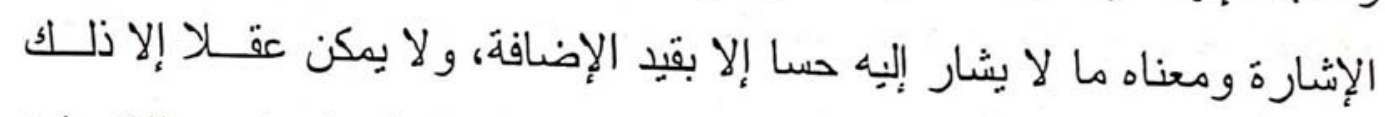

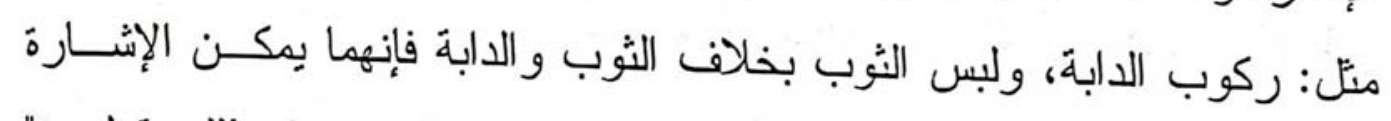

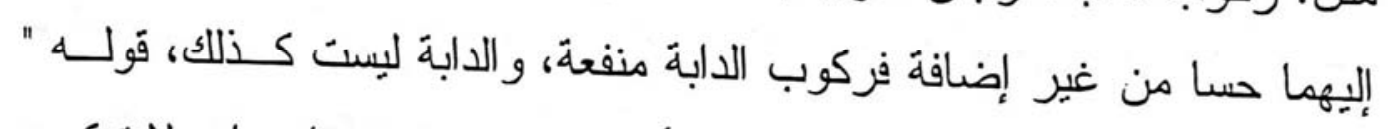

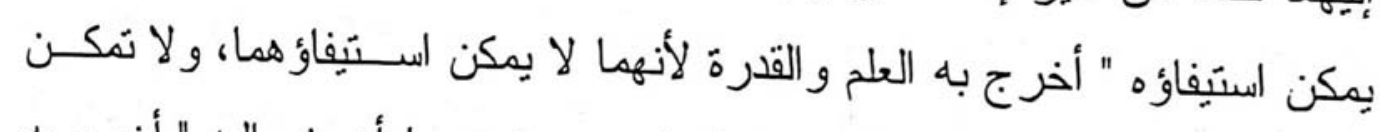

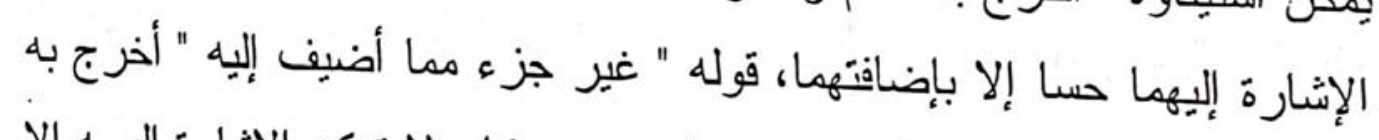

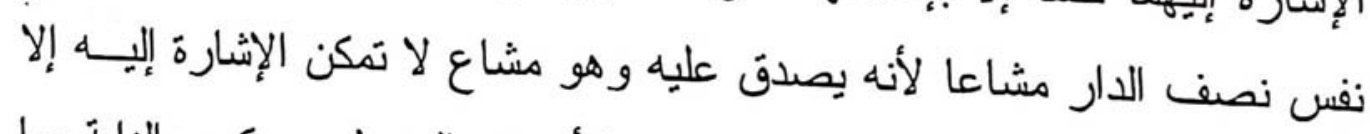

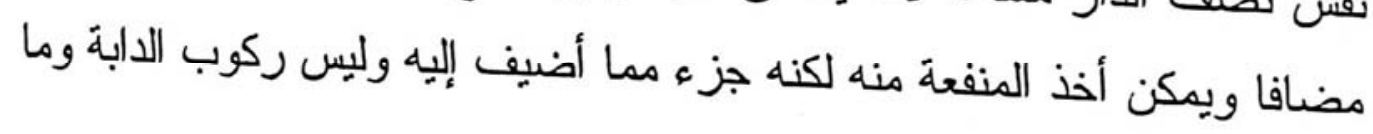

شابهه كذلك " (r)

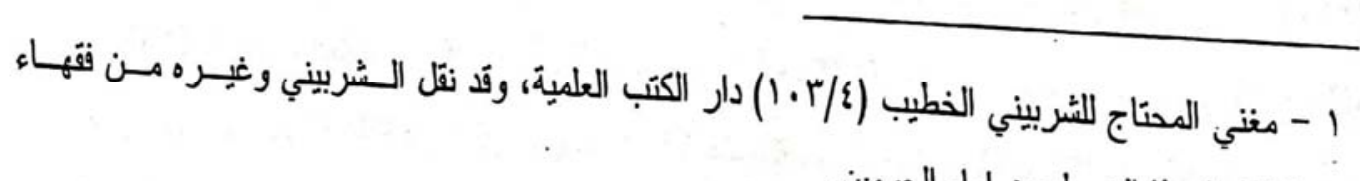
الثافعية هذا الضبط عن إمام العرمين. r - شرح حدود ابن عرفة (T91) 
وجاء تعريفها في مجلة الأحكام بأنها" المنافع - جمع منفعة - وهي الفائدة

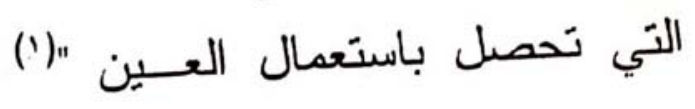

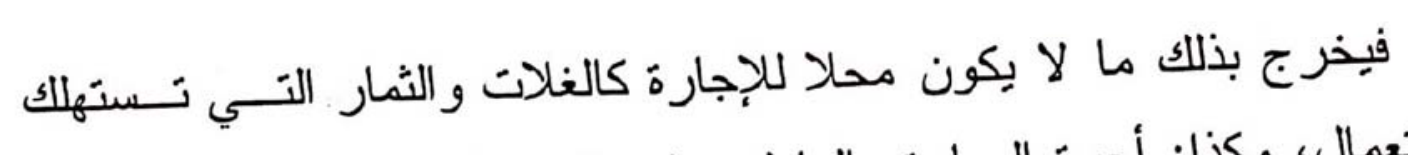

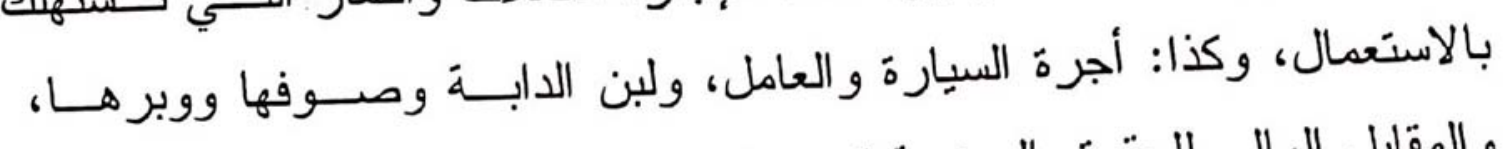

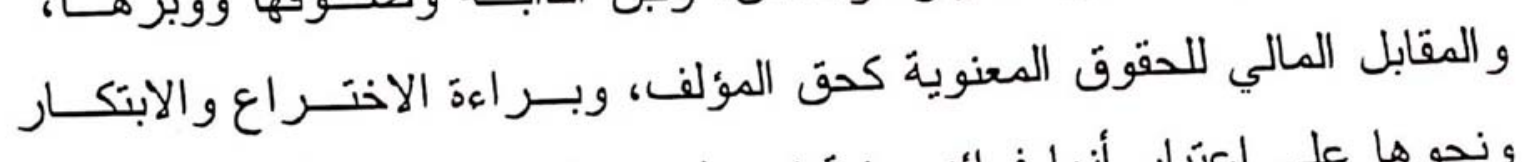

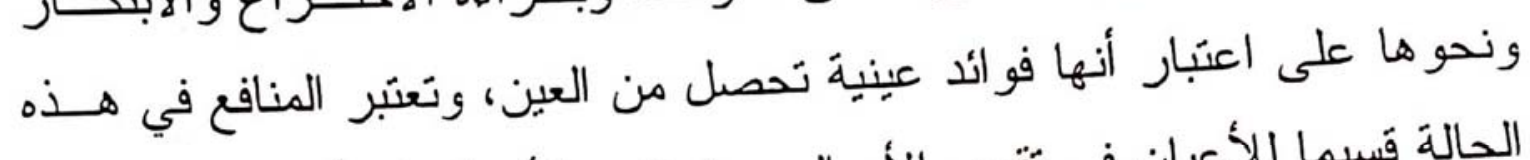

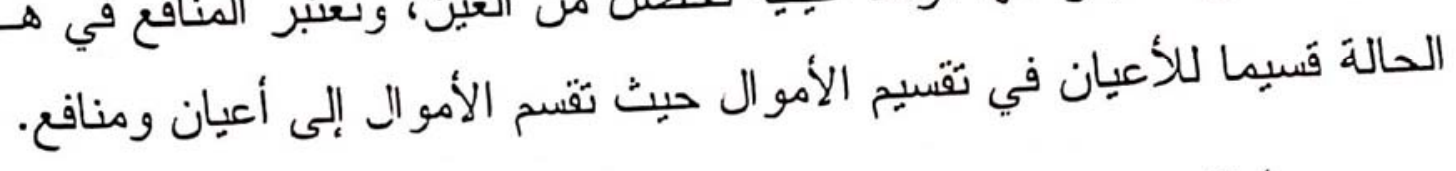

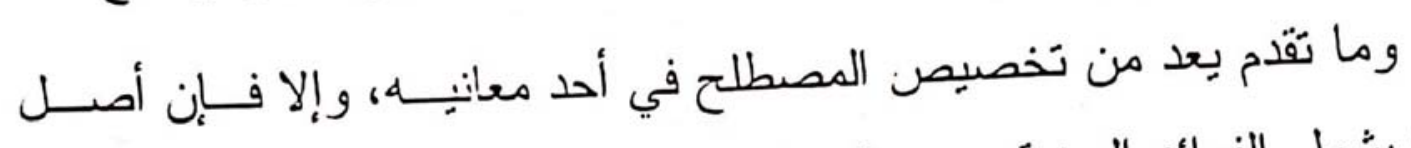

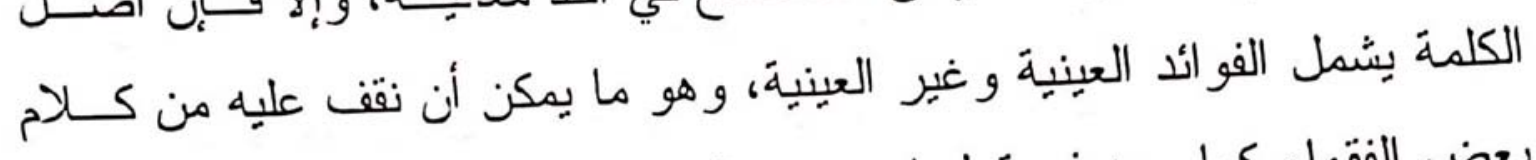

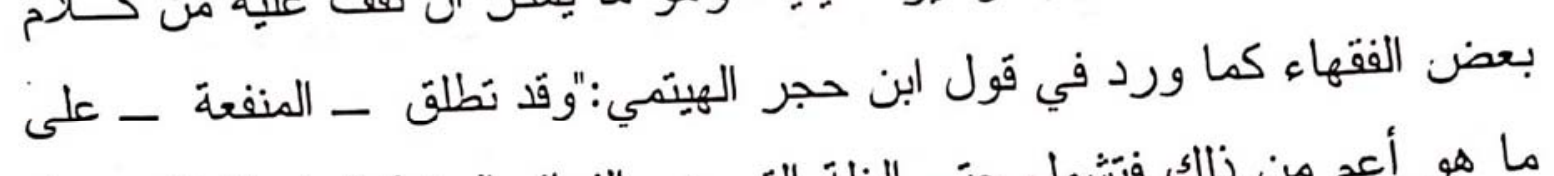

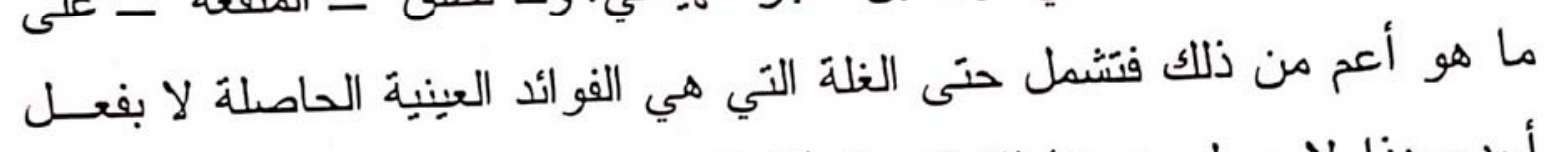

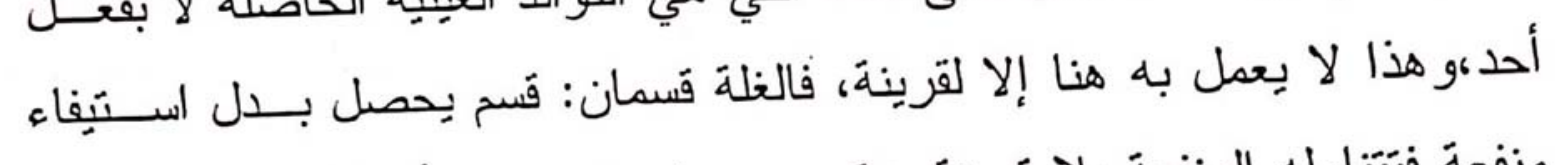

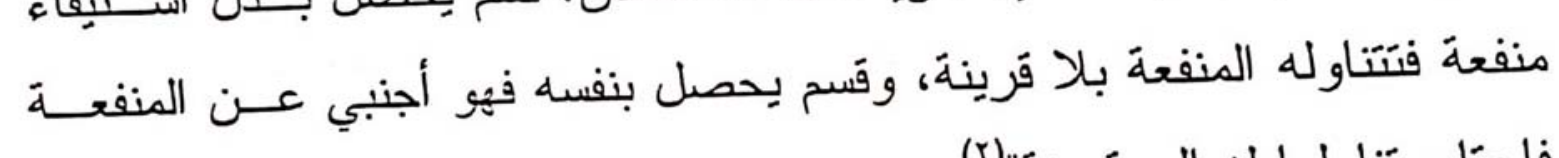

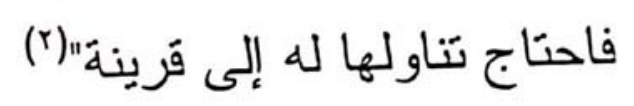

وقال في الفتاوى في باب الوصية بالمنافع محررا للخلاف:" لـــ قَامـــ

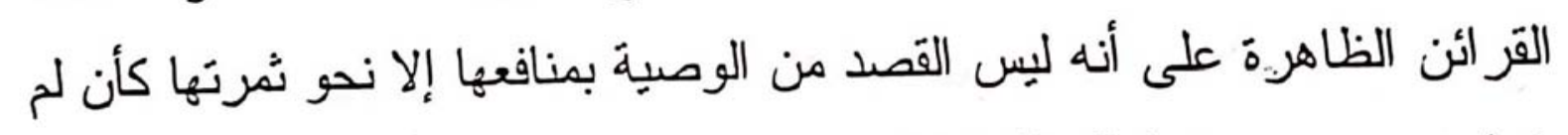

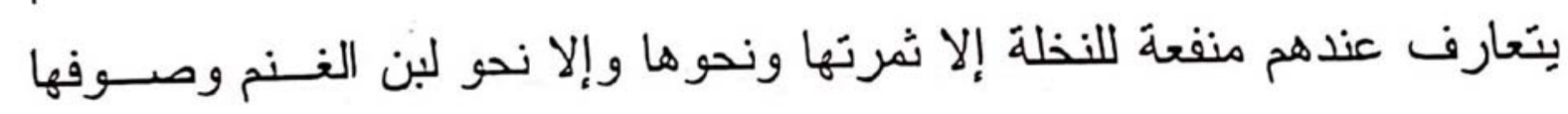

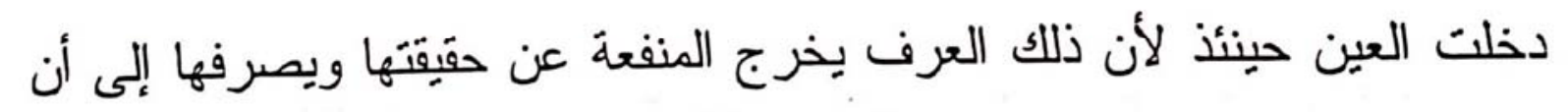

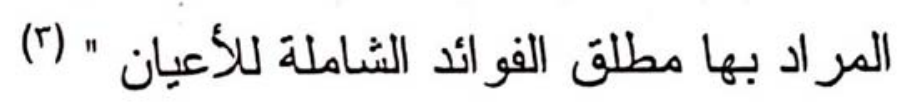

1 - درر الحكام في شرح مجلة الأحكام لعلي حيلر (110/1) دار الجيل.

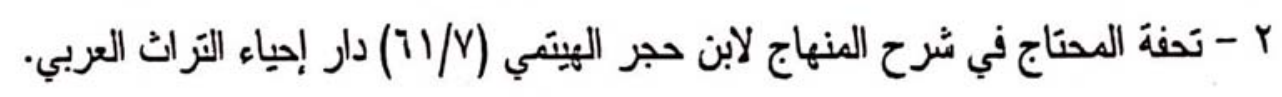

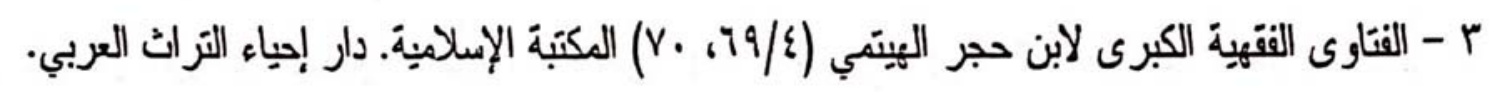


ونقل ابن حجر الهيتمي، والشربيني الخطيب عن السبكي قوله:" و المنــافع و الغلة منقاربان، وكل عين فيها منفعة فقد يحصل منها شيء غير تلك المنفـسـة

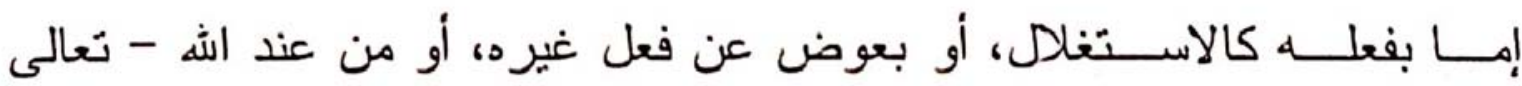

- وذلك الشيء بسمى غلة " (')

وحديثنا في هذا البحث ينصرف إلى المنافع غير العينية.

المطلب الثاني: مدى اعتبار المنافع أموالا.

البحث في مدى كون المنافع أمو الا أو ليست بأمو ال ينصرن إلى المنفعة

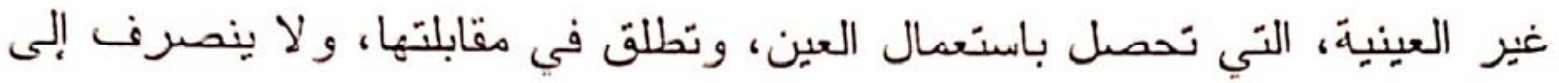
الفو ائد العينية كالغلات و الثُمار ؛ إذ هذه لا اختلاف في ماليتها.

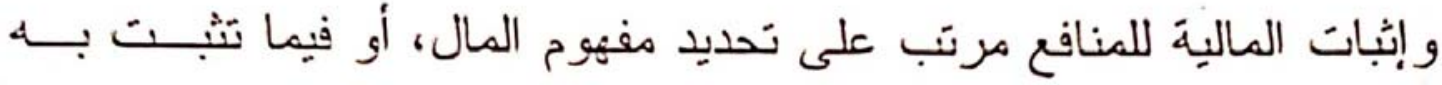

مالية الثيء، وقد اختلف الفقهاء في ذلك على قولين:

الأول: أن الأموال هي كل منمول يحاز ويدخر ، فما لا يحاز ، ولا يدخر لا

يكون مالا. و هو قَول الحنفِِة، وقَد جاء في تَريفهم له:

• المال "ما يميل إليه الطبع، ويمكن ادخاره لوقَت الحاجة "

وقَيل: " المال: انم لغير الآدمي خلق لمصالح الآدمي، وأمكــن

إحر ازهو التصرن فيه على وجه الاختيار"

وقيل: " المال: ما يميل إليه الطبع، ويجري فيه البذل و المنع "(ז)

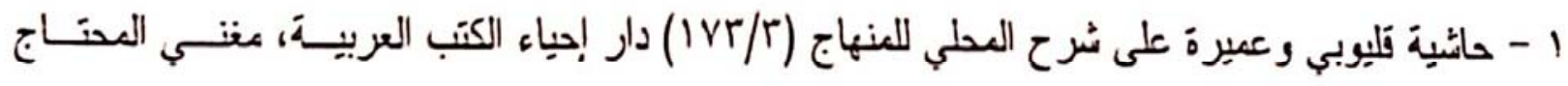

$(1 \cdot r / \xi)$

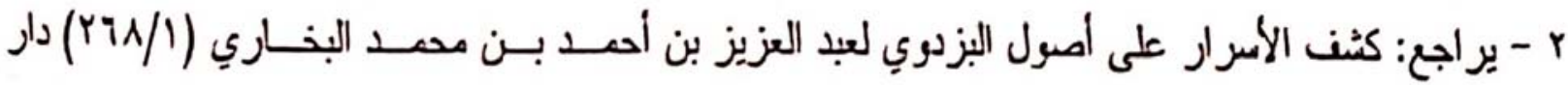

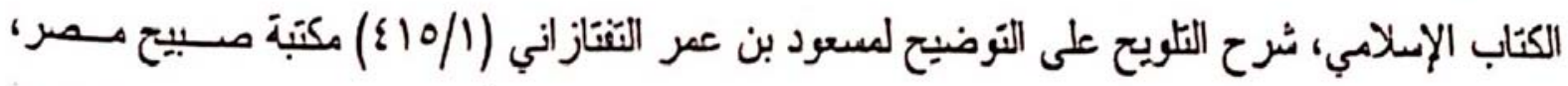

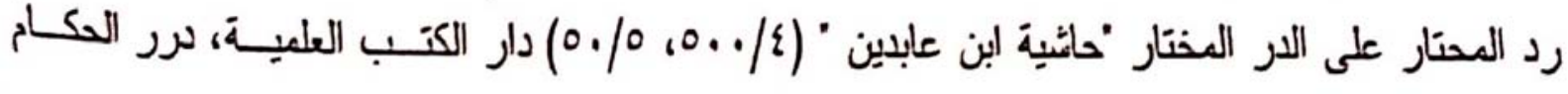


وبناء على ما تقدم من تعريف الحنفية للمال فإنه يلزم لاعتبار كون الشيء

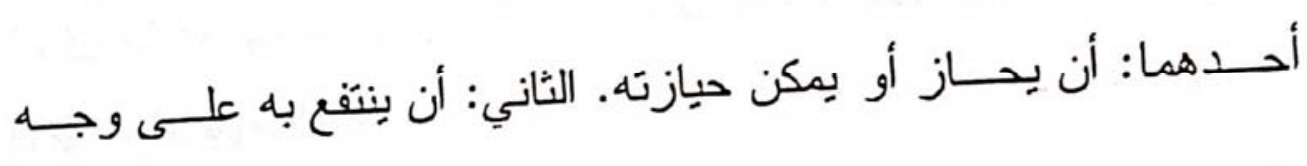

فما يحاز وينتفع به فعلا، أو ما يمكن حيازته فهو مال، وما لا نتمكن مسن

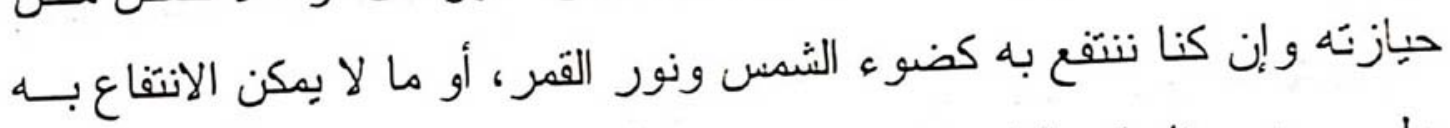

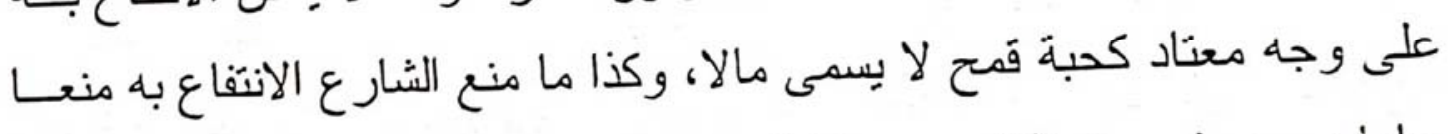
عاما بِري في حق الناس جميعا كالمبنَة. ويخرج من عداد الأموال وفق هذا القول: المنافع والحقوق فليست بأمو ال

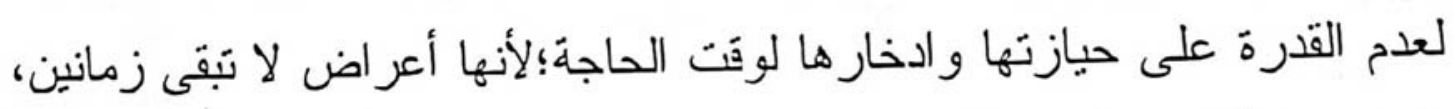
بل تحدث آنا بعد آخر فلا يمكن إحرازها وما لا يمكن إحرازه لا يسمى مالا. (') وقد انتهى الحنفية بأن المنافع وما يجري مجر اها ملك لا مال، قــال ابــن . عابدين: " و التحقيق أن المنفحة ملك لا مال ؛ لأن الملك ما من شأنه أن ينصرف فيه بوصف الاختصاص، و المال ما من شأنه أن يلخر للانتفاع وقت الحاجة " (؟) وقد أخذ على التعريفات المتقدمة للحنفية ما بلي:

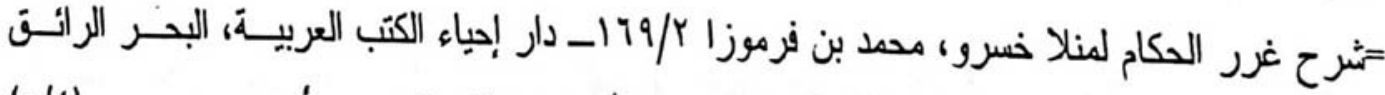

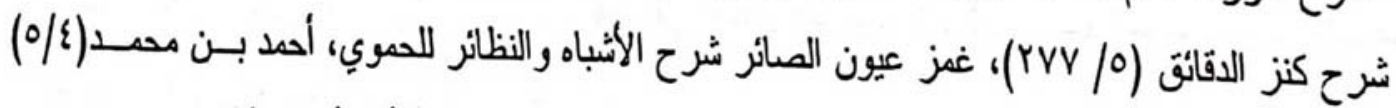

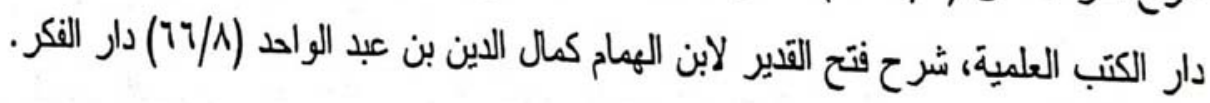
1 - المبسوط لشمس الأئمة السرخسي (1I/IV) دار المعرفة.

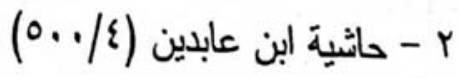


أو لا: قولهم بأن المال " ما يميل إليه الطبع " يردد عليــهـ أن هنــاك مـنـ

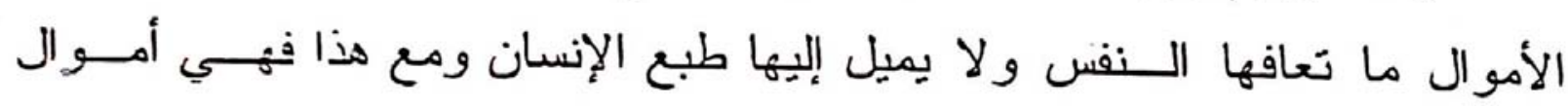
كالسموم والأدوية المرة.

ثانيا: هناك ما لا يمكن ادخاره على نحو تبقى منفعتَه ومع هذا فهو مــال

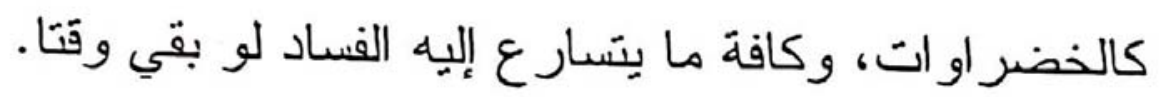

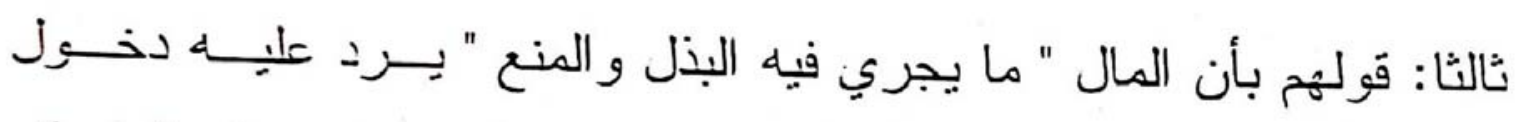

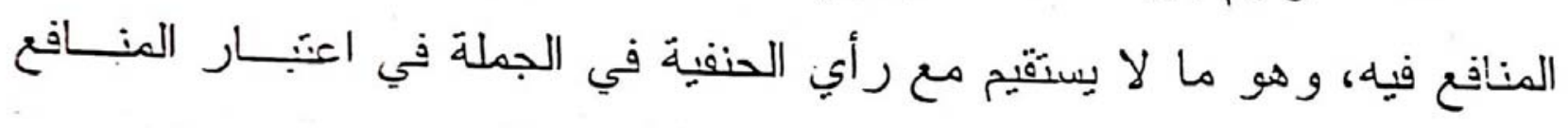
أمو انخ.

القول الثاني: أن المال هو كل ما ينتفع به، عِينا كان أم منفعة، وههَ فَــل المالكبة ،و الشافعِية، و الحنابلة.

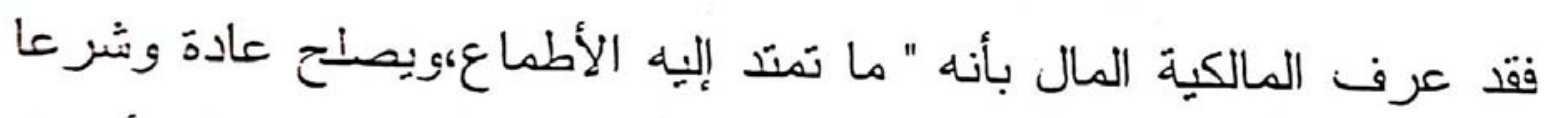

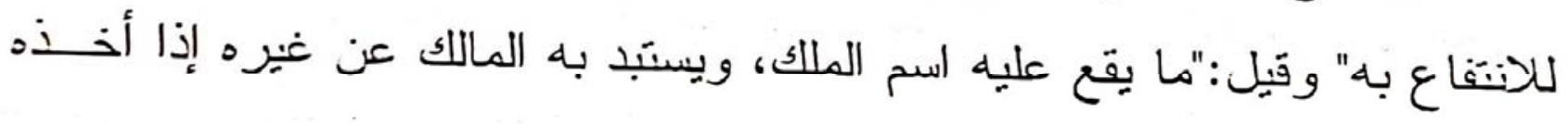

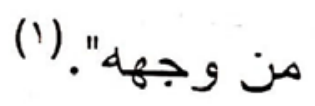

و عند الشافعية: المال " ما كان منتفعا به "وقيل أيضا: "العلل ما لـه قَيِــة

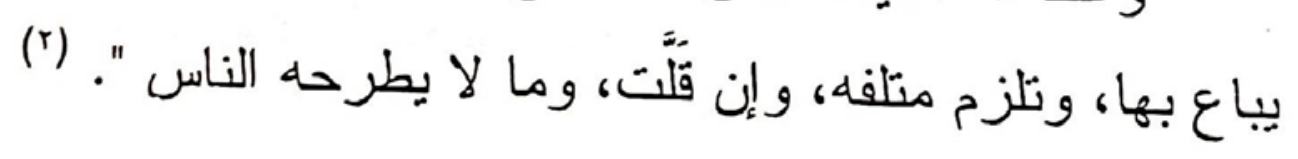
و عند الحنابلة:المال:ما يباح نفعه مطلقا،ؤو يباح اقتتاؤه بلا حاجةَ، وقَيل:" ما فيه منفعة لغير ضرورة" (r)

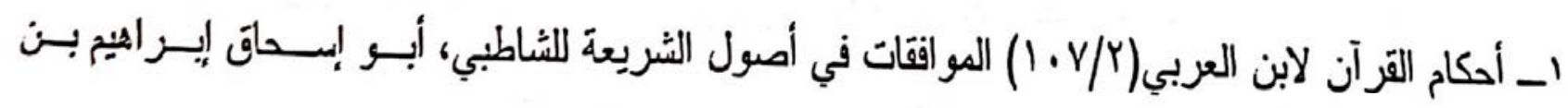
هوسى اللخمي(Y/Y) دار إحياء الكتب العربية.

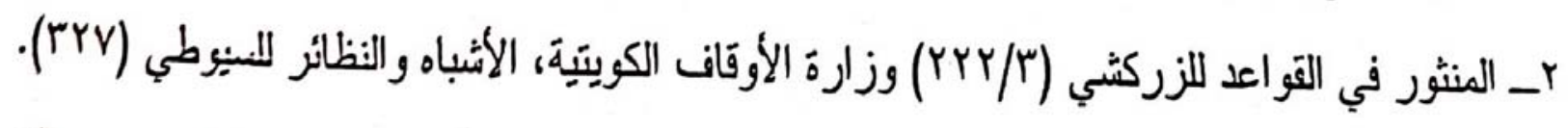

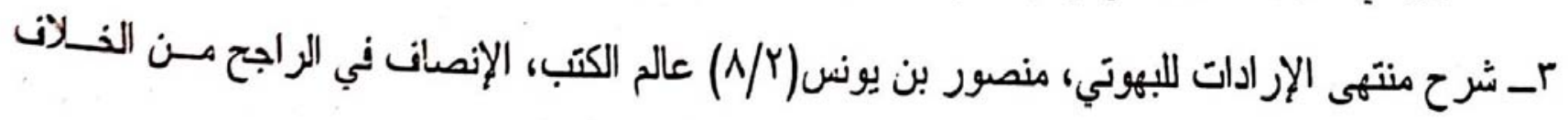

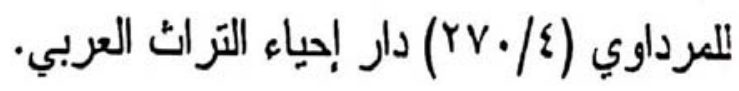




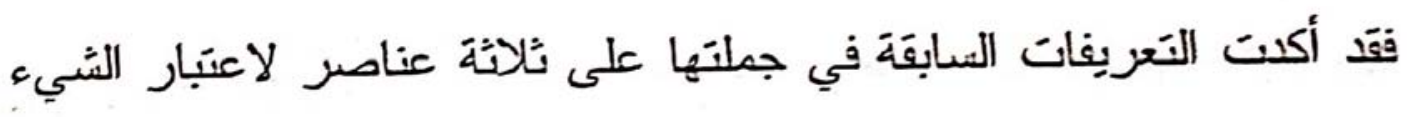

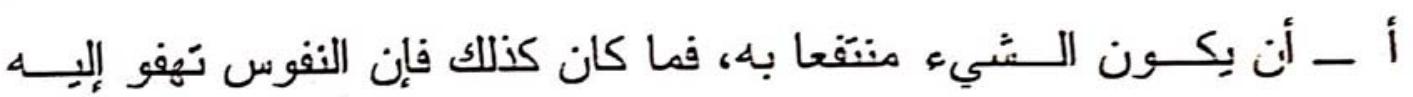

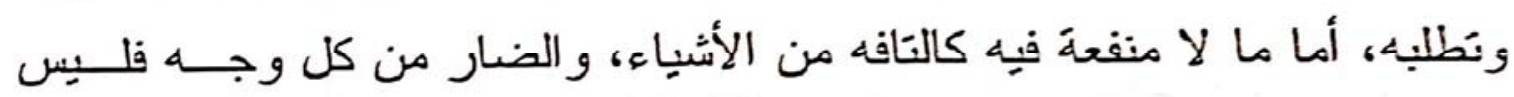
بمال.

ب - أن نكون المنفعة مباحة، فالمنافع غير المباحة كالخمر ونحوها ليست بمال لتَبَت تحريم النَحامل في الخمر ونحوها.

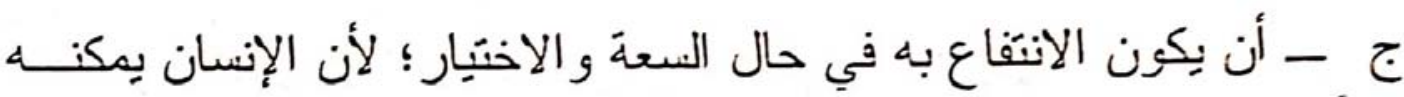

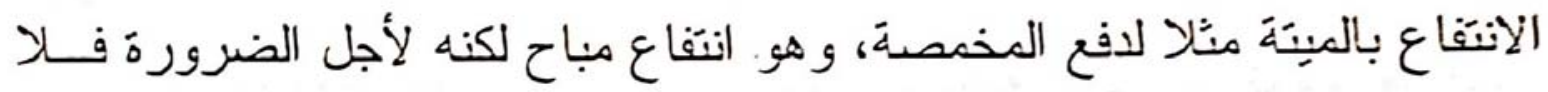
يكئون مالا.

و لاشك أن ما ذهب إليه الجمهور هو الأرجح؛ لأن كلمة " المال " جـاءت

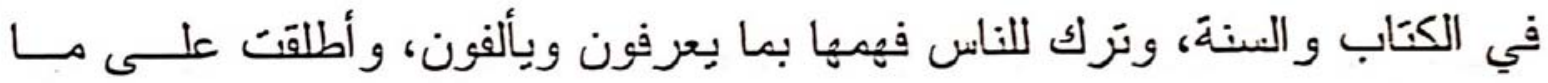

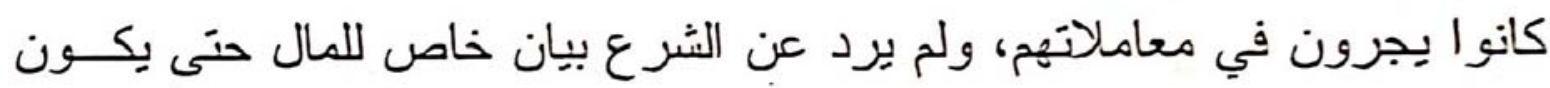

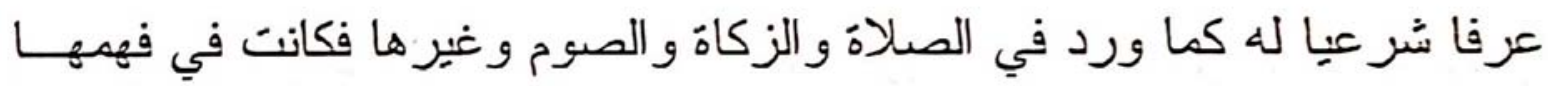

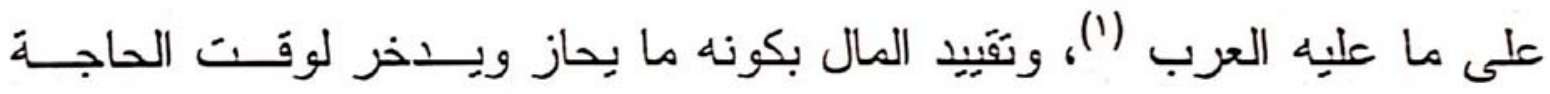
تخصيص بغير مخصص؛ إذ لم يأت نص بذلك، وليس محنى أن غالب الأمسوال

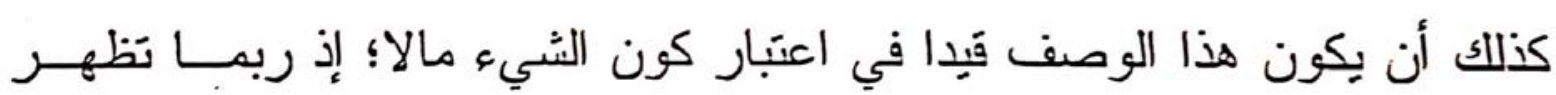

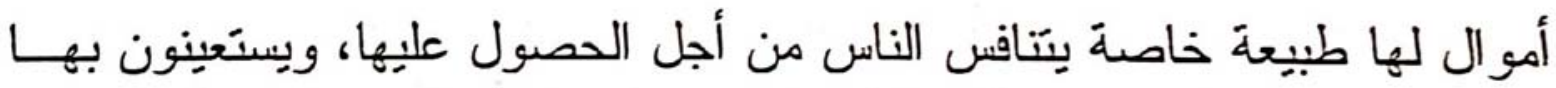
في ََضاء حو ائجهم، و لا يمكن حيازتها ولا ادخار ها.

1 - الملكية ونظرية العقد للغيخ محمد أبو زهرة (\&) دار الفكر العربي. 
و القاعدة ": أن كل ما ورد به الشر ع مطلقا، ولا ضابط له فيه، ولا فــي اللغة يحكم فيه العرف"(')

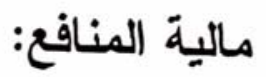

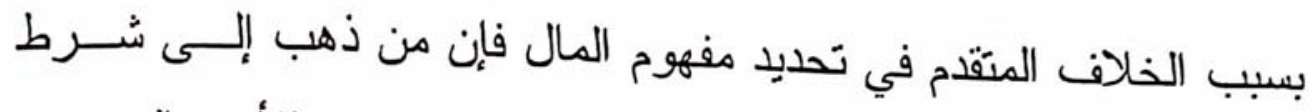

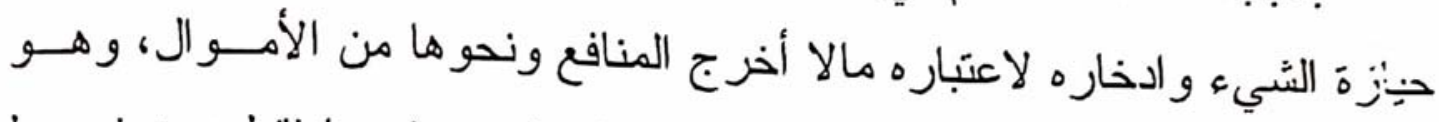

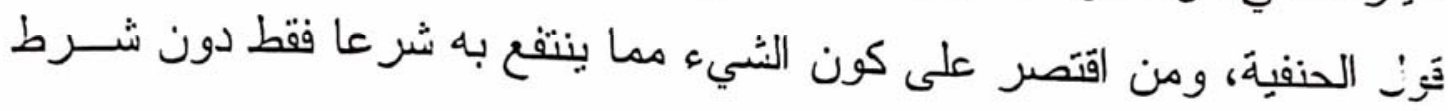

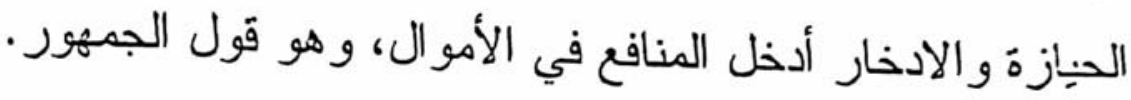
وجه قول الحنفية في إخراج المنافع من الأموال:

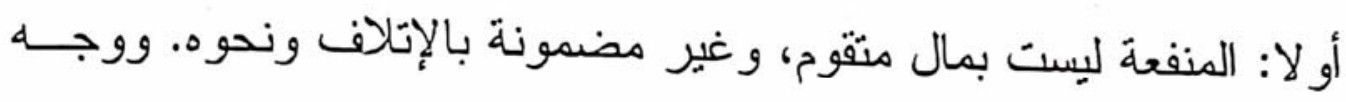

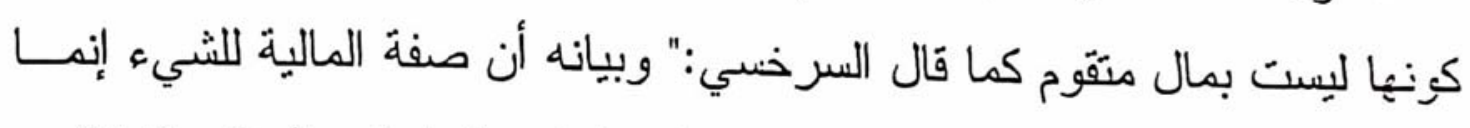

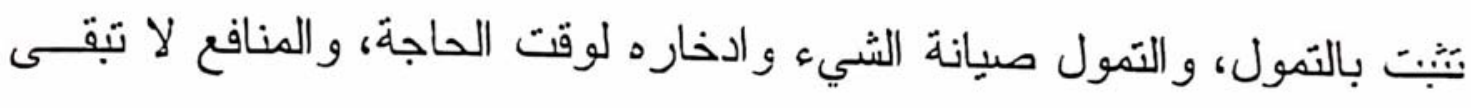

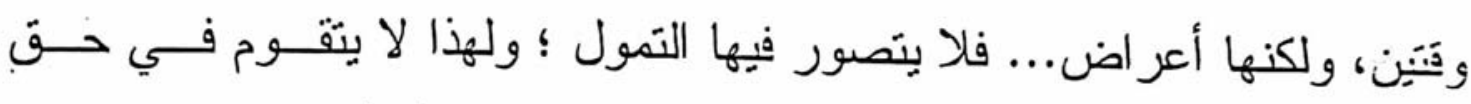

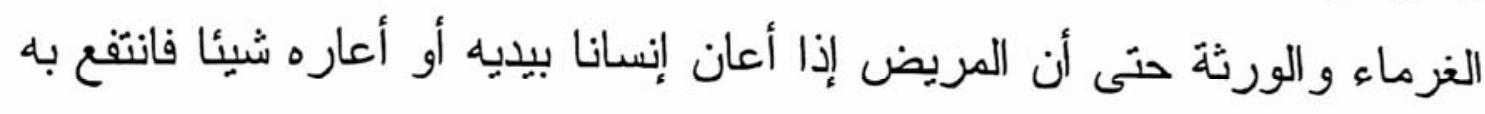

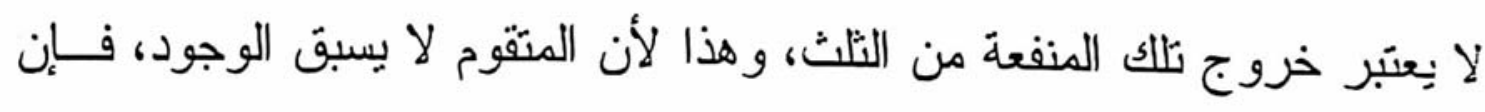

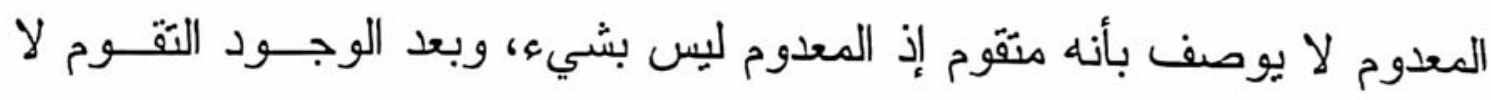

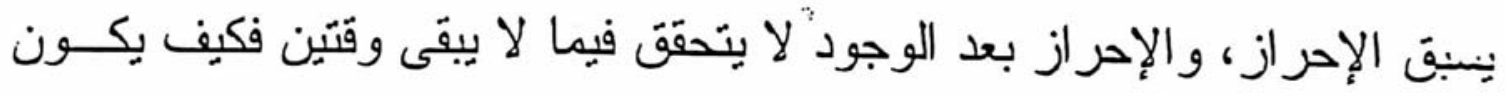
منتَوما". (r) ويمكن مناقشة هذا الوجه: بأن المنفعة متمولة، ودليلن تمولها اعتياد الناس و اعتبار هم لها في تجار اتهم ومعايشهم.

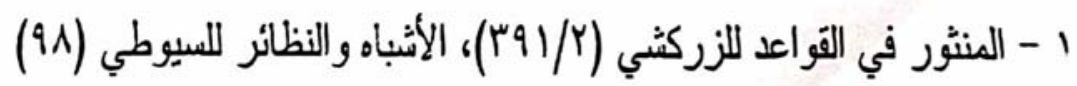
r - المبسوط (11/11) كثّف الأسرار (179/1) 
ثانيا: أن المنفعة لا تماتل العين ومن ثم فلا تأخذ أحكامها وتكون دونهــا.

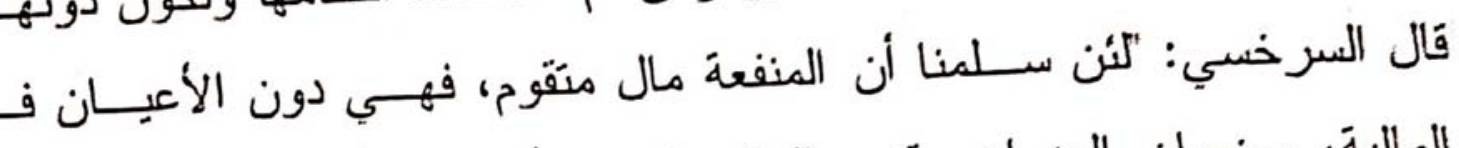

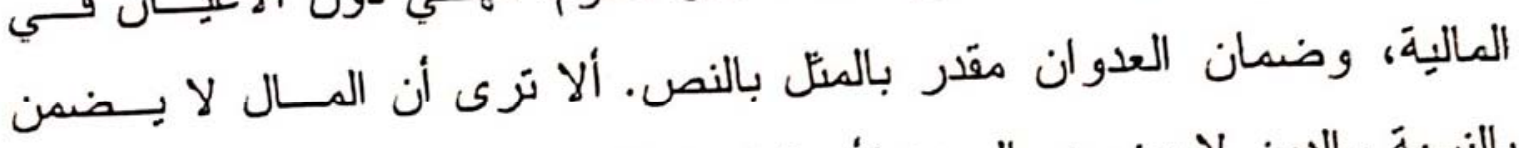

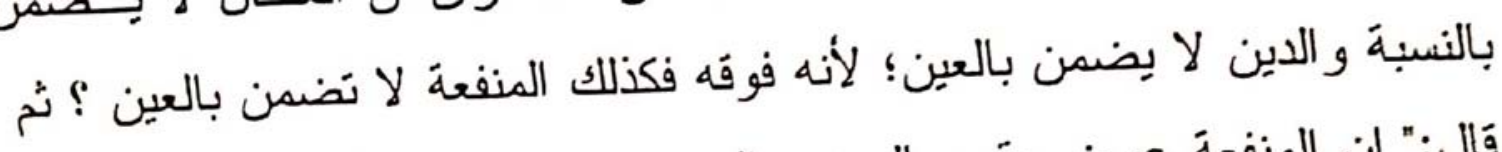

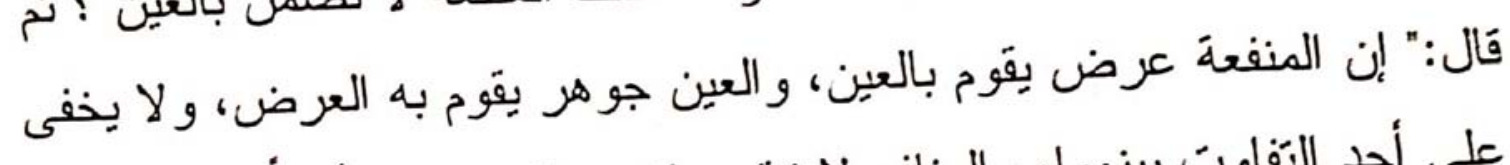

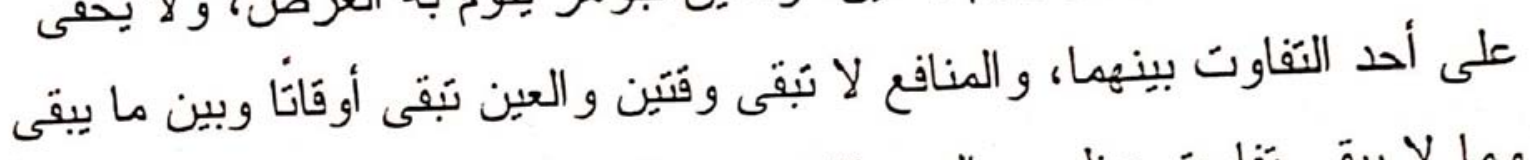

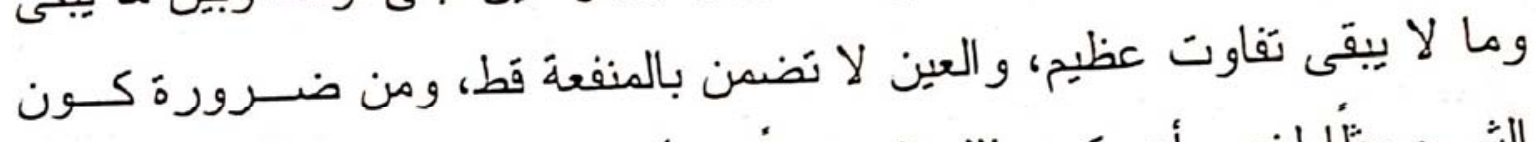

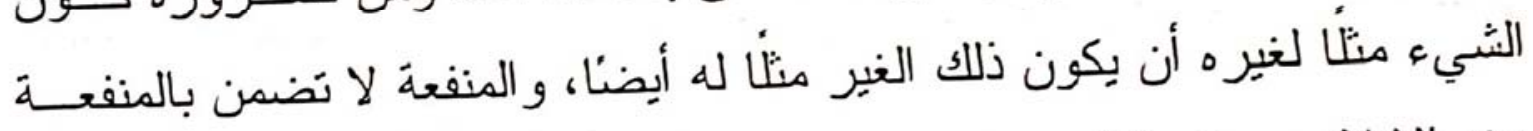

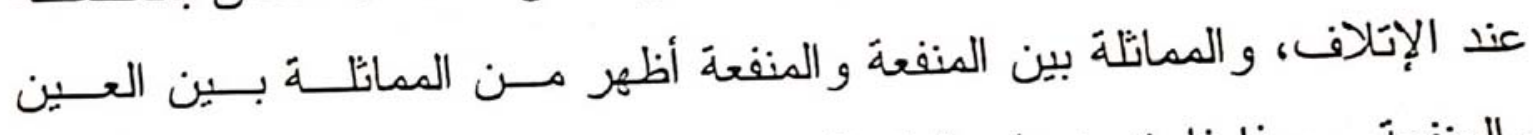

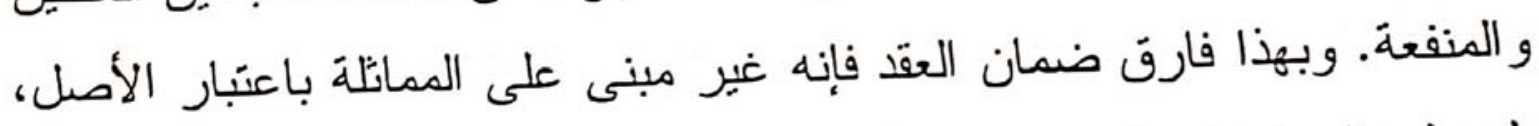

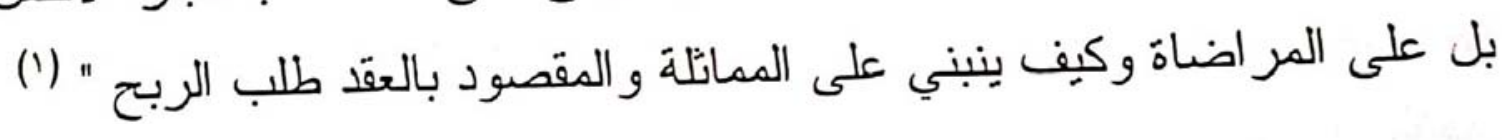
ويناقش هذا الوجه: بأنه لا يلزم من كون المنفعة دون الأعيان و أنها ليست

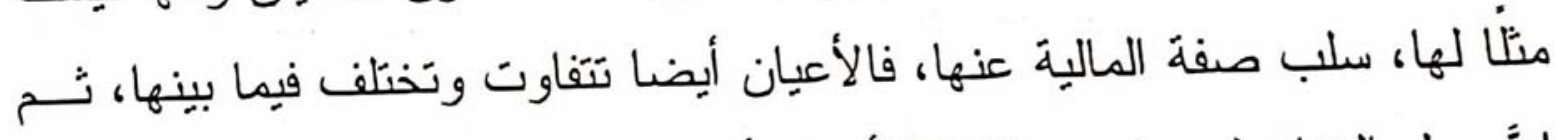
إنَّ محل النزاع ليس في مماتلتها للأعيان أو عدمه، و إنما هو في ماليتها وتقومها،

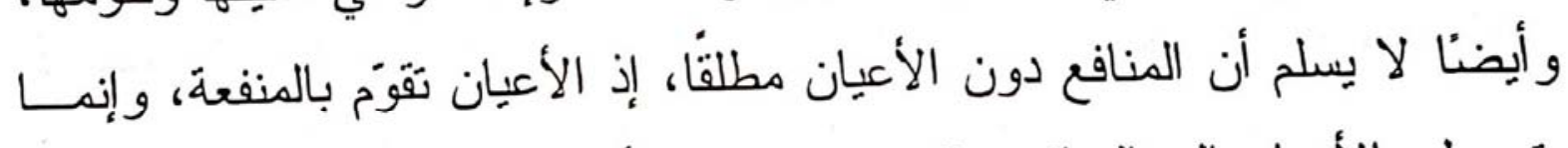
يتوصل بالأعيان إلى المنافع، فالمقصود منافع الأعيان لا ذاتها.

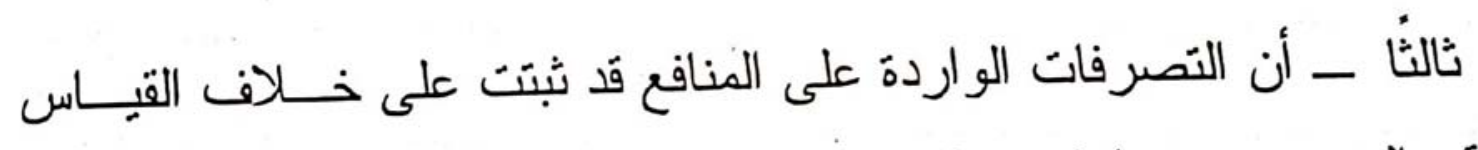

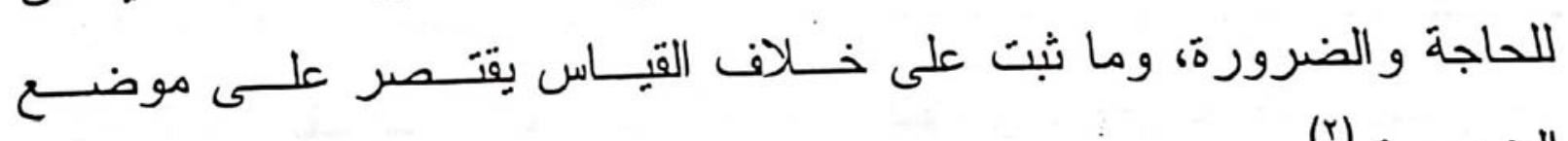

الضرورة.

$$
1 \text { - المبسوط (VN/11) }
$$

r - المبسوط (11/1)، كثف الأسرار (179/1) 
وهنا التوجه مردود بدا صح في النصوص من تجويز كون المنافع مهزا،

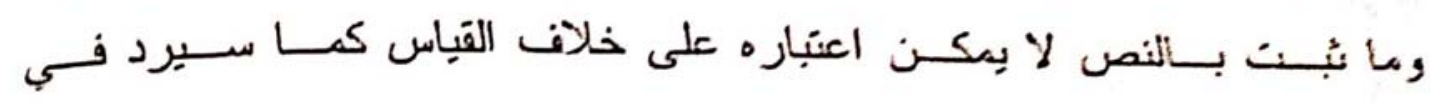

الأسنت لد لقول الجمهور .

\section{ووجه قَول الجمهور:}

أو لا: أن المنافع هي الغزض الأظهر من جميع الأمو ال.

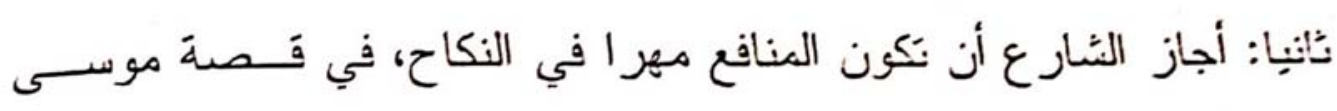

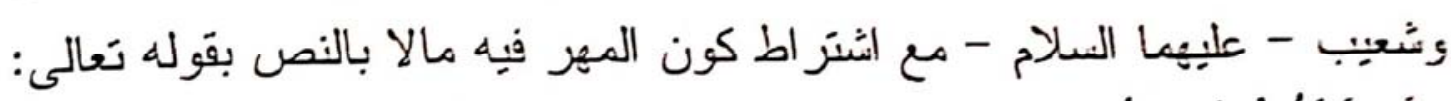

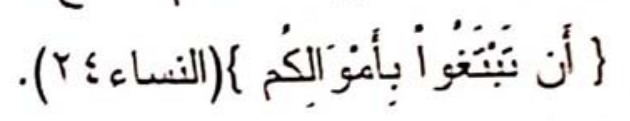

ثالثا: أن المال اسم لها هو مخلوق لإقامة مصالحنا به، أو هو - كما يقول

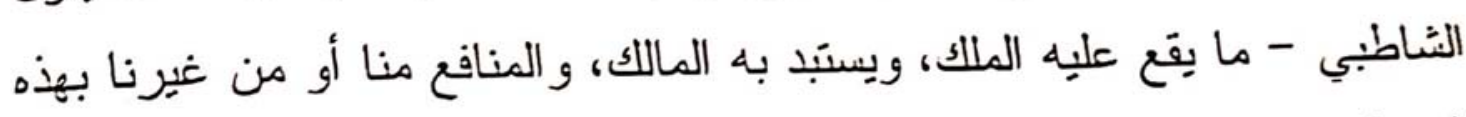

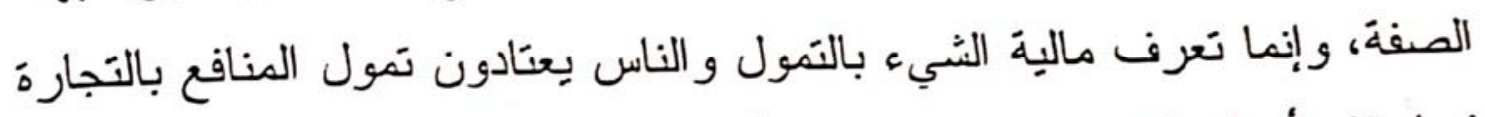

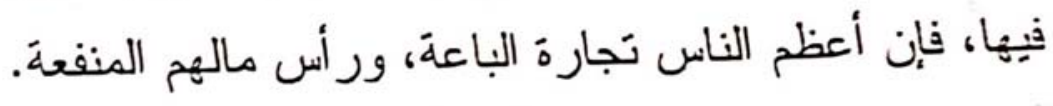
جاء في كثف الأسرار استكلالا لقول الجمهور " أن المنافع أمو ال منقومة

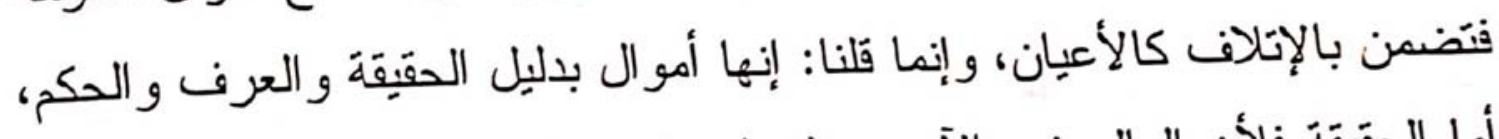

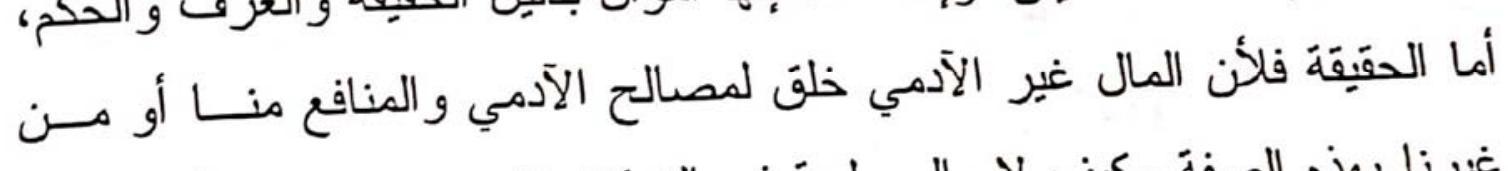

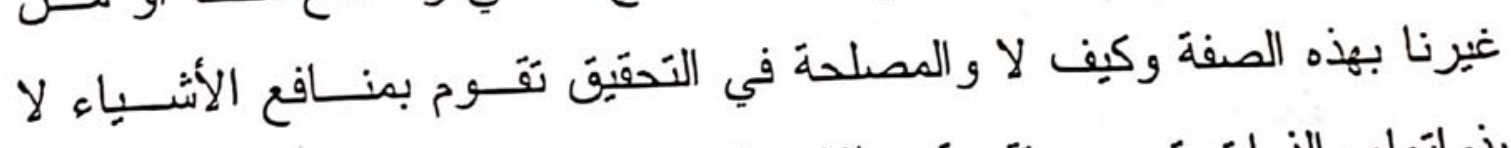

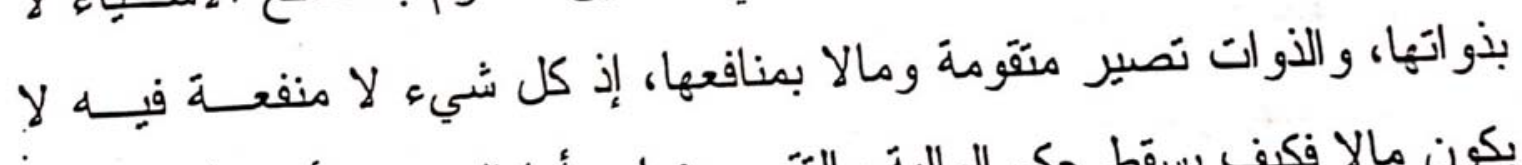

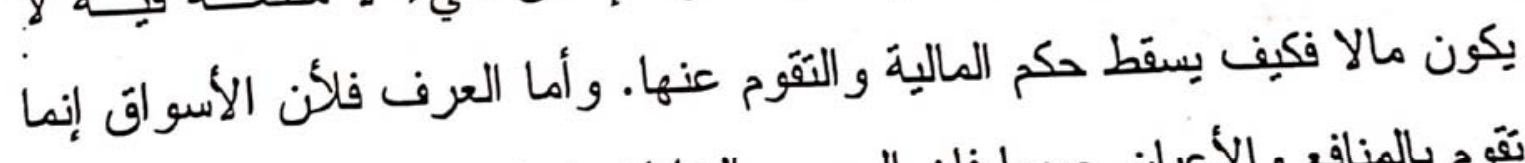

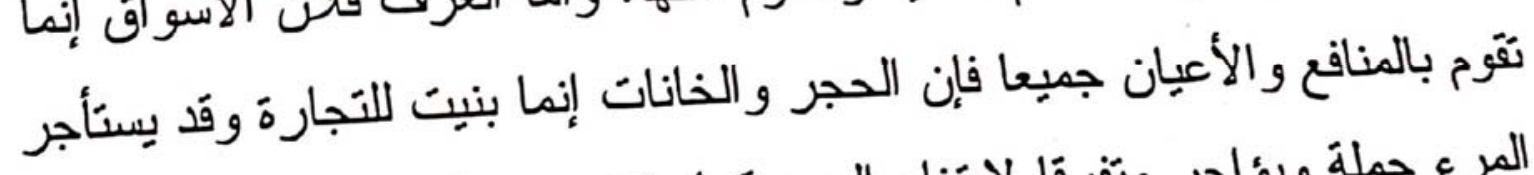

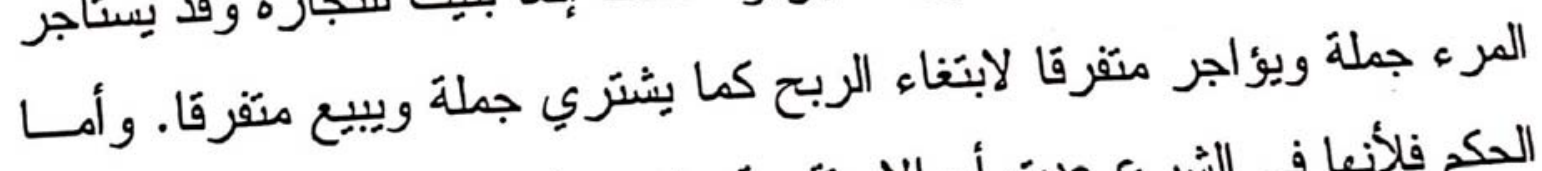

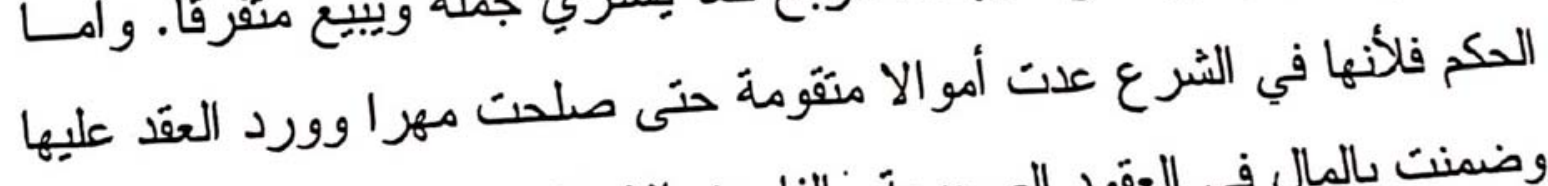

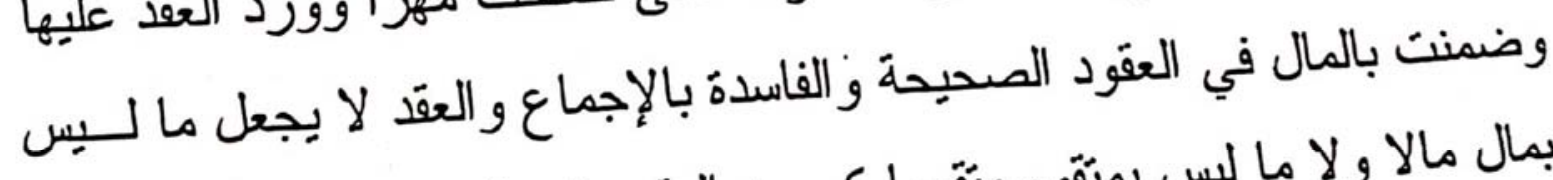

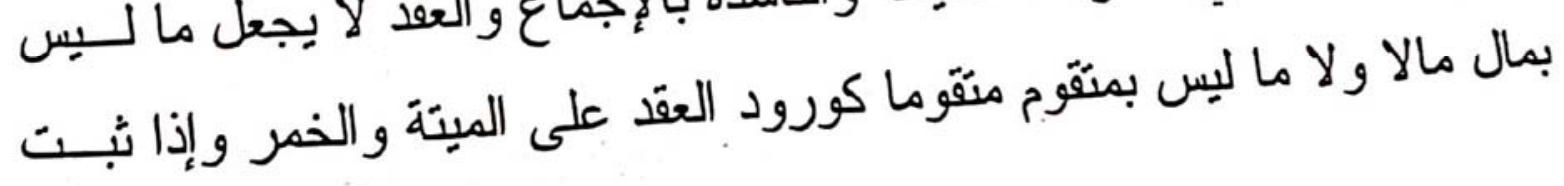




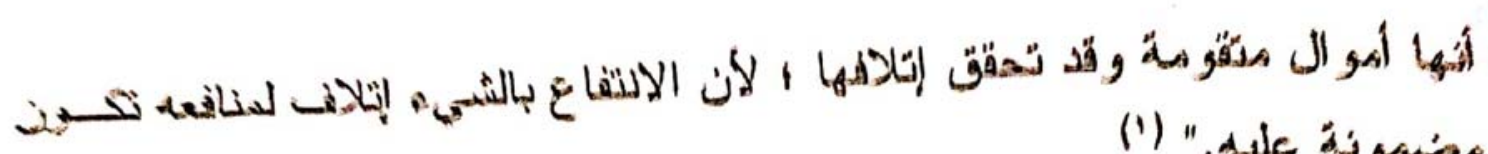
(i) ". Aple ajguias

رابعا: ان المدفعة المباحاة: المئقومة،، تجبر في العقود الفاسدة والـصحيحة.

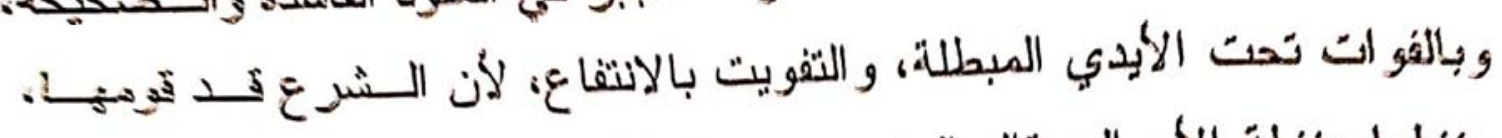

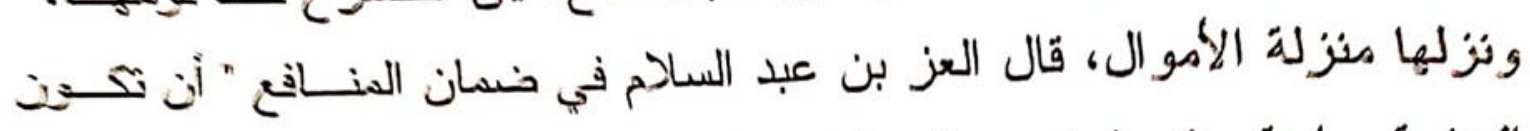

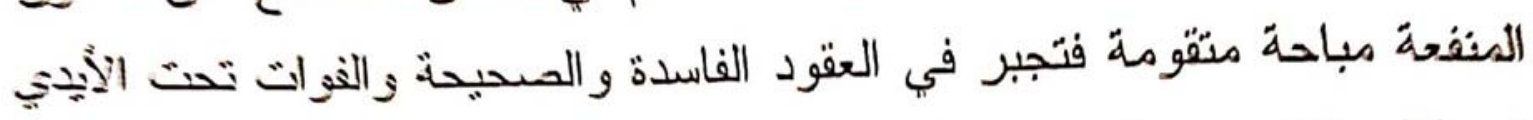

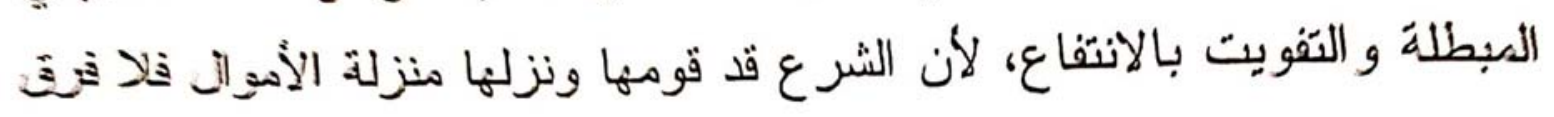

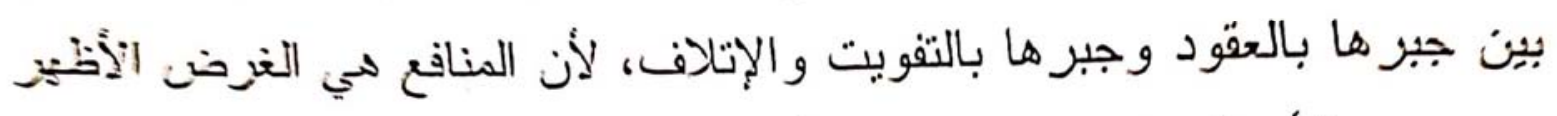

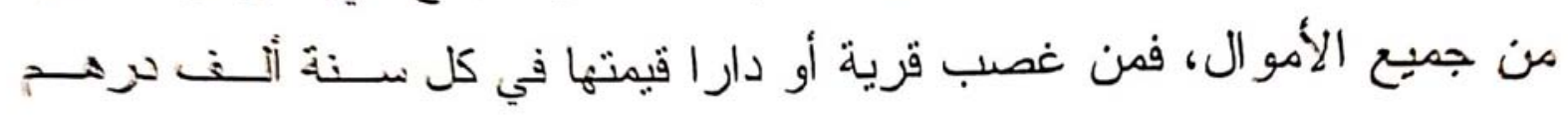

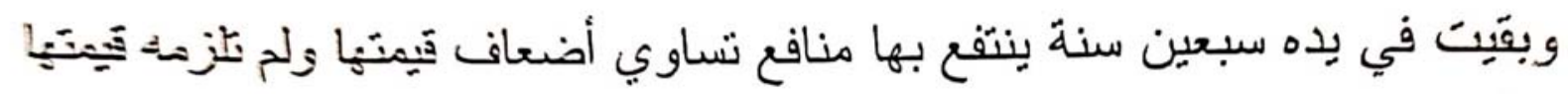

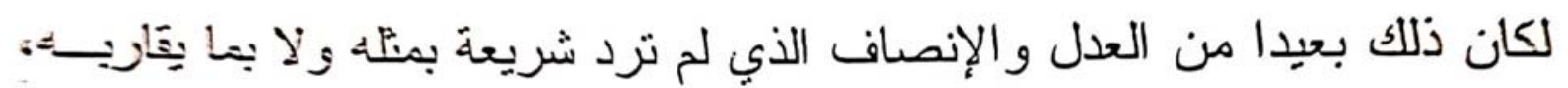
و هذا كله في منافع الأعيان المملوكة..." (r)

خامسا: أن المنافع المباحة يجري فيها ما يجري في الأعيان من التيـــقـــ

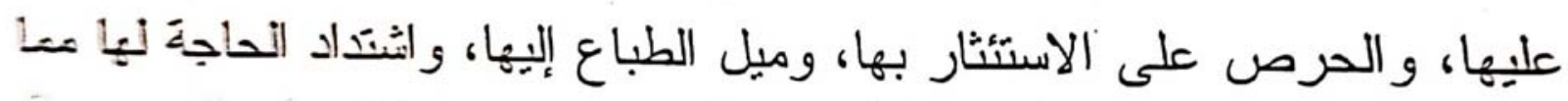
يؤكد كونها مالا.

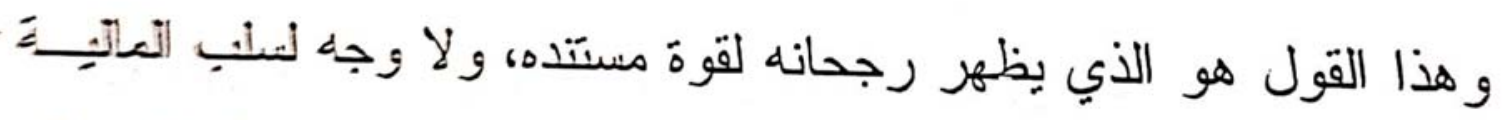

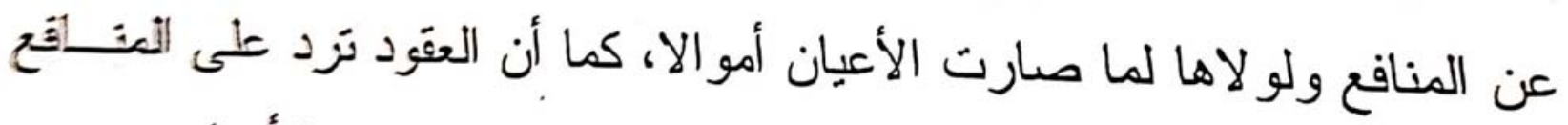

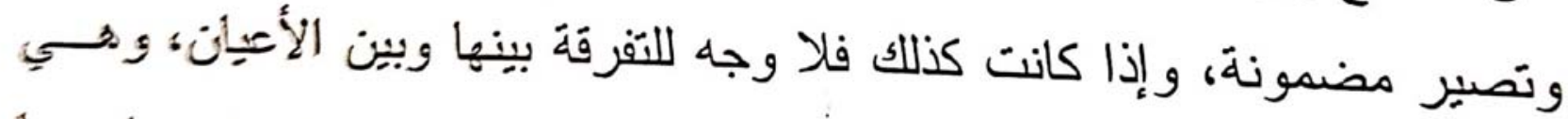

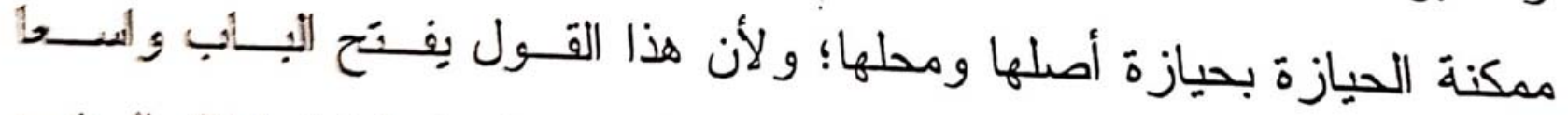
لاستيعاب كثير من صور و ألوان المنافع المعاصرة، فإن المالية كما قَل الــنَيخ

1 - كثن الأسرار - موضع سابق.

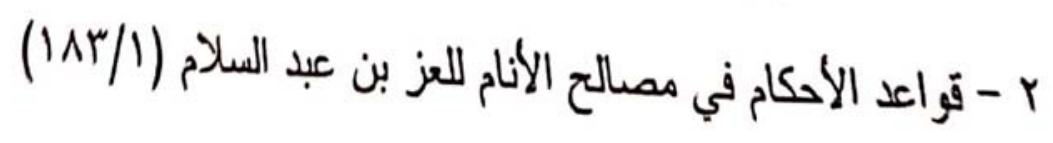




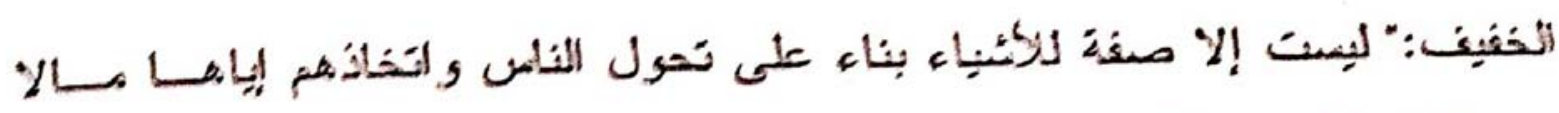

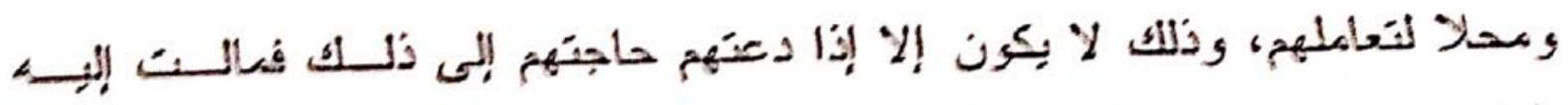

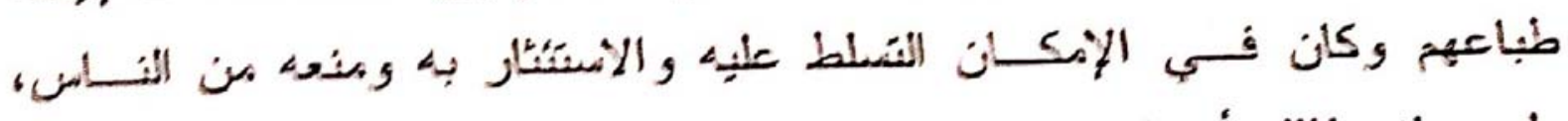

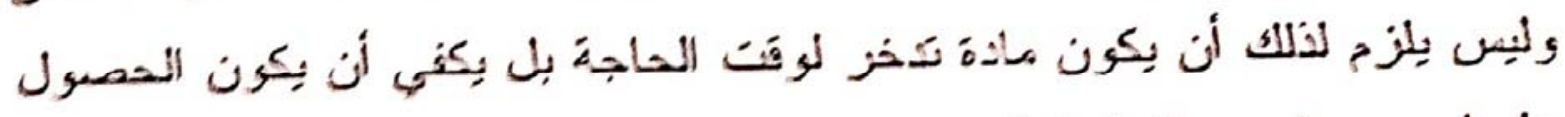

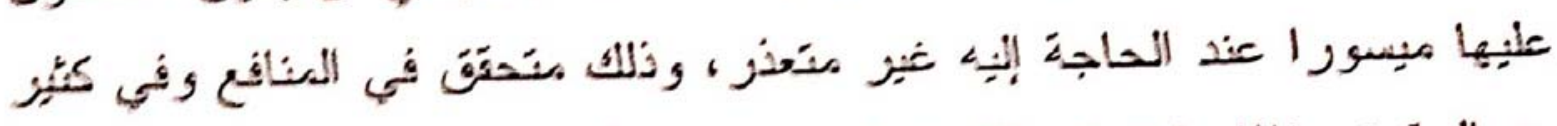

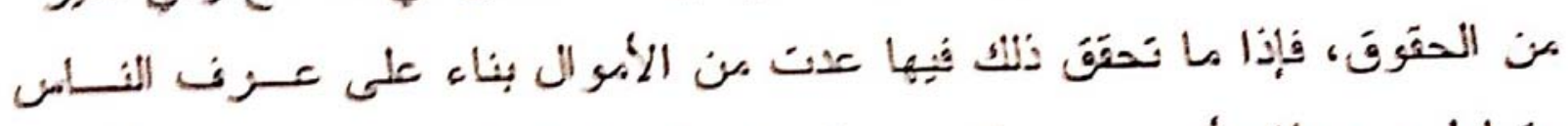

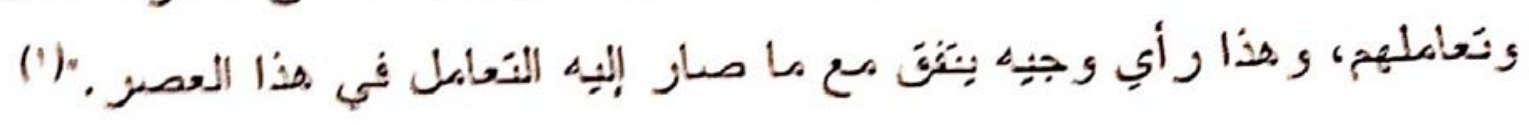
المطلب الثَالث: ما يزيد على المنافع من عقود:

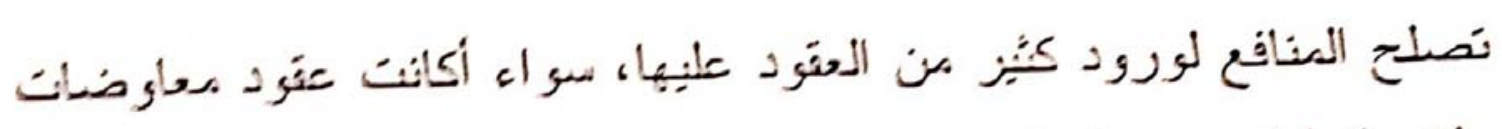

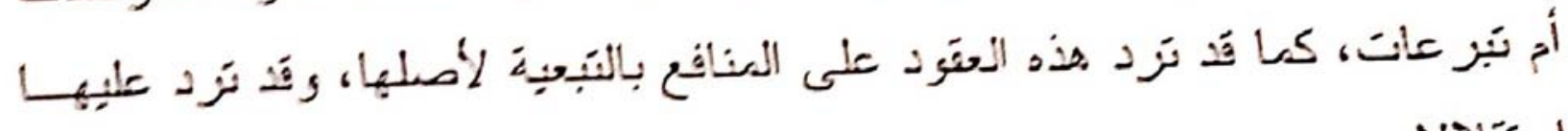

اسنتقلالا.

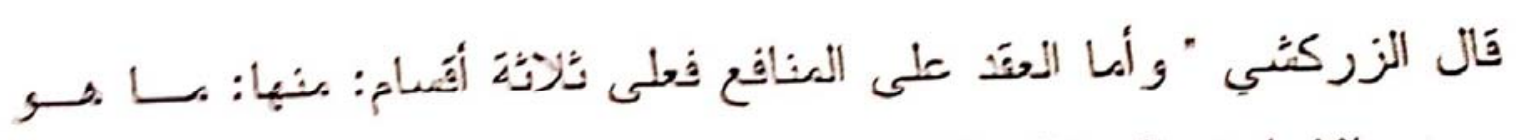

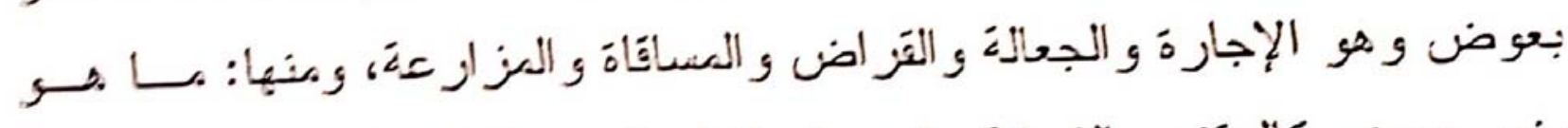

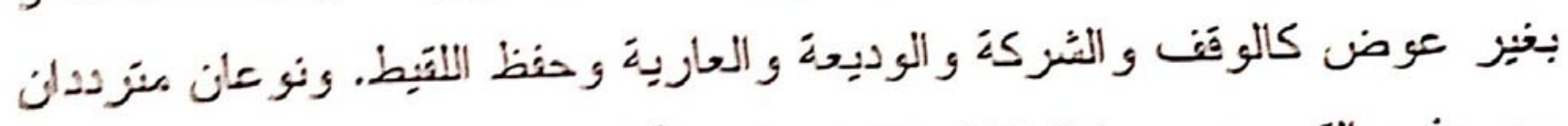

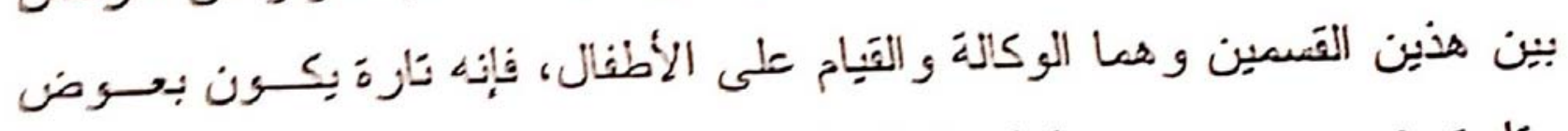

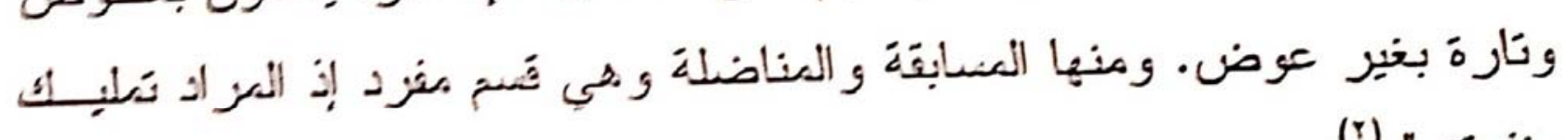
(r) " منفحتَه

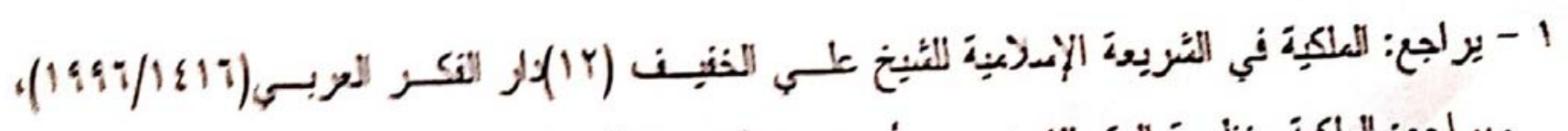

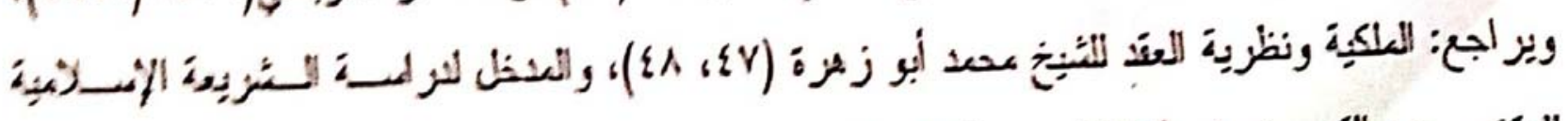

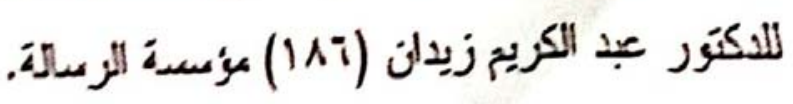

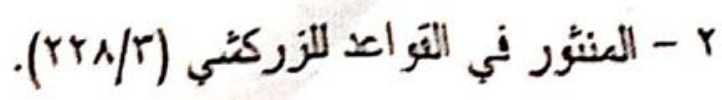




\section{المبحث الثاني}

\section{حكم وقف المنافع}

يِختلف حكم وقَف المنفعة باختِلاف أحو الها فقد توقَف هي والأصل معا،

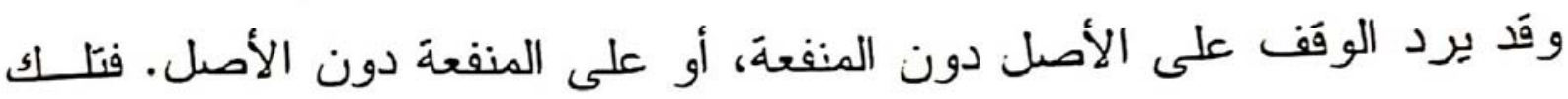
تَلات مسائل نتتاولها في المطالب الآتِِة: المطلب الأول: وقف الأصل و المنفعة معا.

هذا هو الأصل في الوقف، وبه تظطر أغر اضله وتتحقق مقاصده، و عنـــ إطلاق الوقف فإنه يشمل الأصول و المنافع بكافة أنو اعها، وقَ حده كثيــر مــن الفقهاء بأنه: "حبس العين و التصدق بالمنفعة " فكأن المنفعة هـــي الأســاس فـي الوقَف، ولو لا المنفعة المبتغاة من الوقَت ما كان له كبير فائــدة، كمــا اشــترط الققهاء في الموقوف: أن يكون مما ينتنع به على خلاف في تفصبل هذا الشرط، ويقتضي هذا: أنه إذا لم يكن للموقوف فائدة أو منفعة معتبرة فلا يصح الوقـفـ، و عند إطلاق الوقف فإنه يشمل منافع الثيء الموقوف وفو ائده.

قال السرخسي:" و لأن المقصود من الوقف منفعة سائر العباد " (1) فإذا لـــ توقف المنفعة مع الأصل بطل المقصود من الوقف؛ ولذلك فإن المنفعة تئول إلى الموقوف عليه بمجرد الوقف وترتفع ولاية الواقف عن المال الموقوف. قال ابن قدامة " من وقف شيئا وقفا صحيحا فقد صارت منافعه جميعها للموقوف عليــه وز ال عن الو اقف ملكه وملك منافعه " (r)

$$
\begin{aligned}
& 1 \text { - المبسوط (Y Ir/Yr) } \\
& \text { r - المغني (ror/0). }
\end{aligned}
$$




\section{المطلب الثاني: وقف الأصل دون المنفعة.}

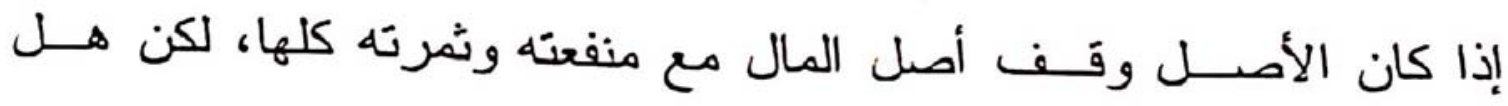

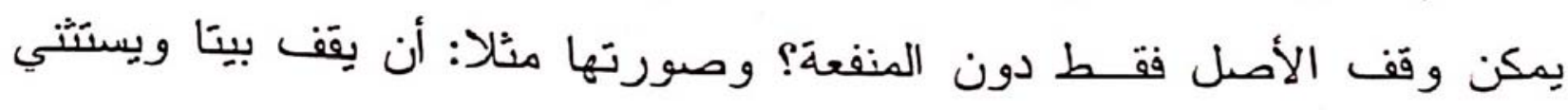

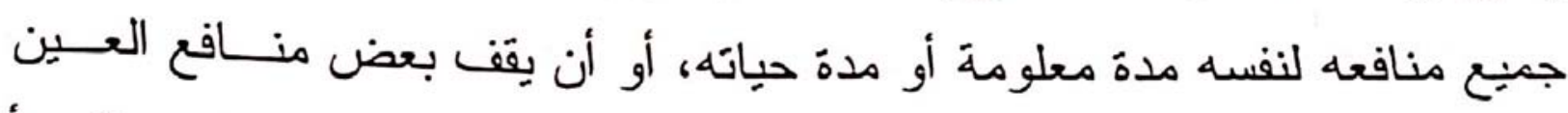

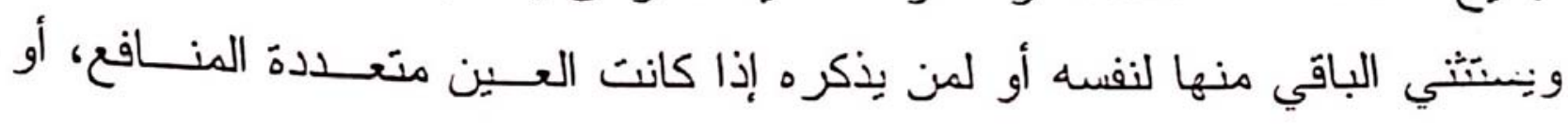

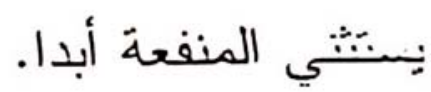

فتلك ثلات حالات:

الحالة الأولى: استئناء منفعة الوقف جميِعها مدة معلومسـة أو مــدة حيــاة الز اقَف.

للفقهاء في استثناء منفعة الوَف مدة معلومة أو مدة حياة الو اقف قو لان:

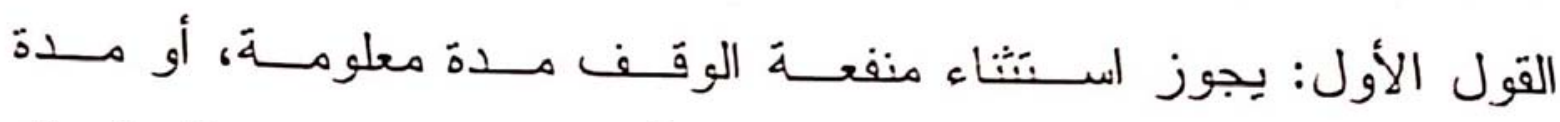

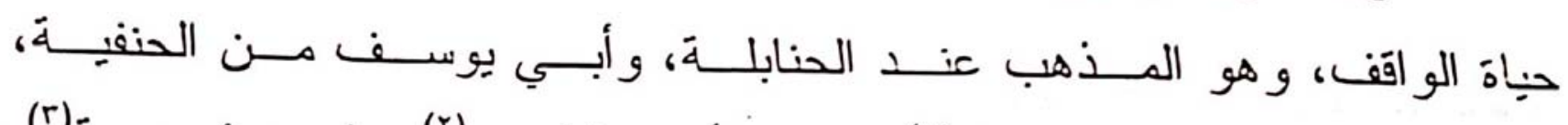

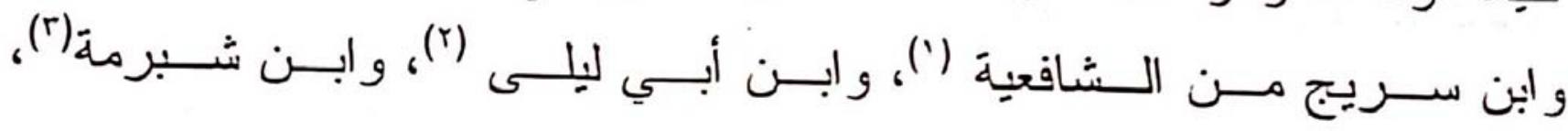

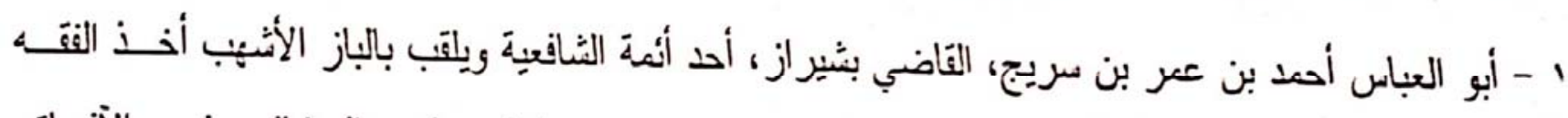

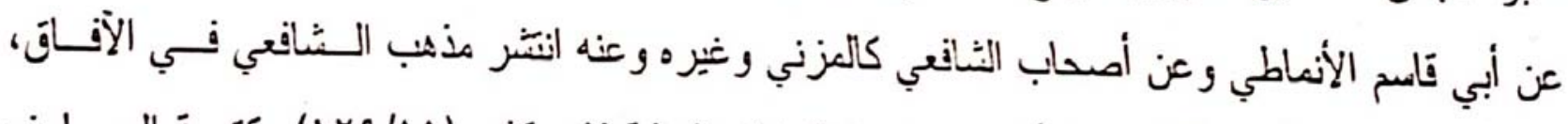

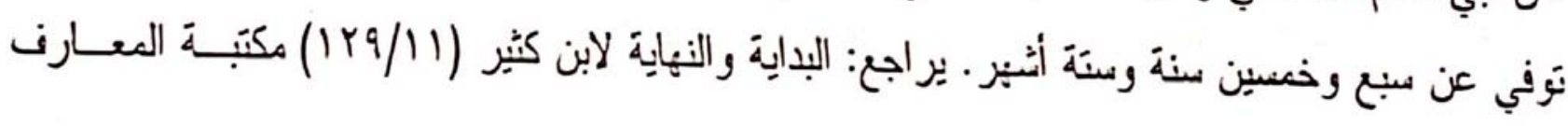
بيزوت.

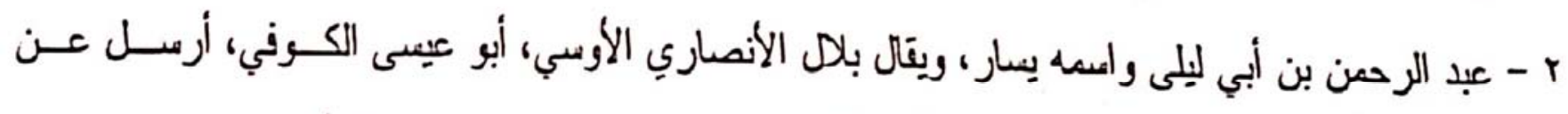

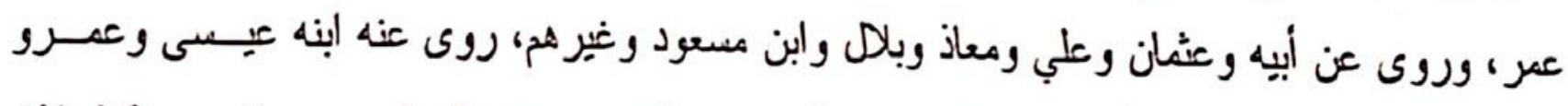

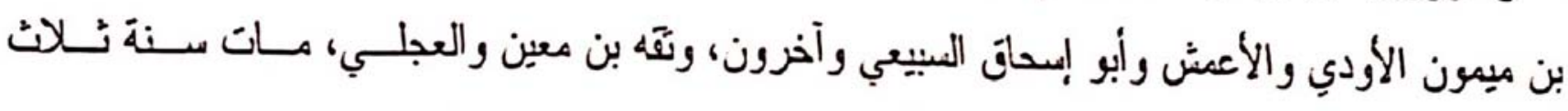

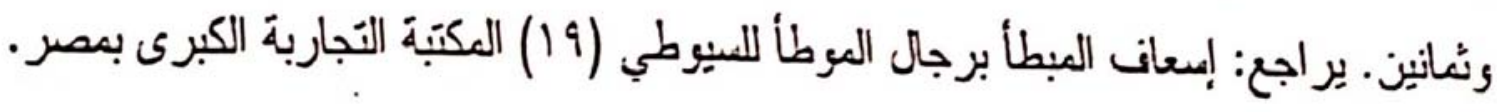

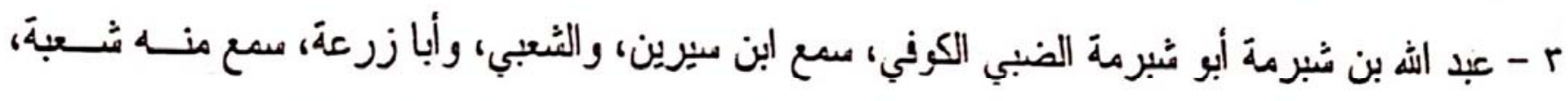

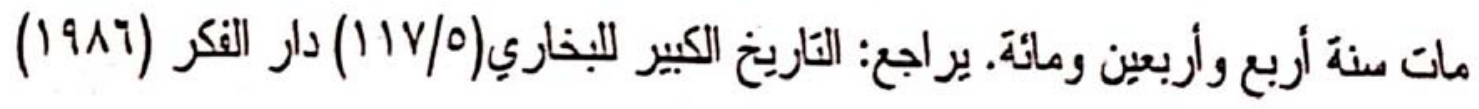


قال الكمال بن الهمام: " شرط الغلة لنفسه وجعل الولاية إليه. أما الأول

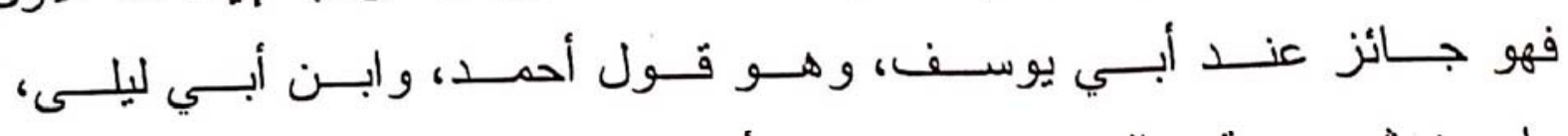

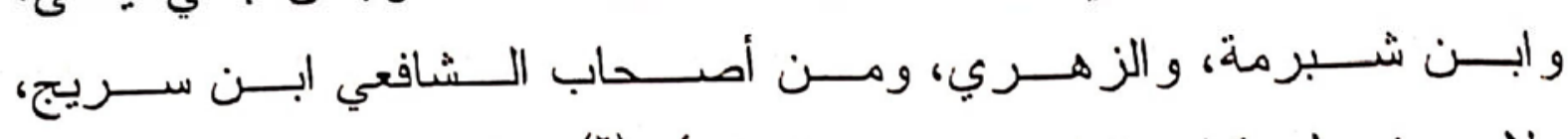

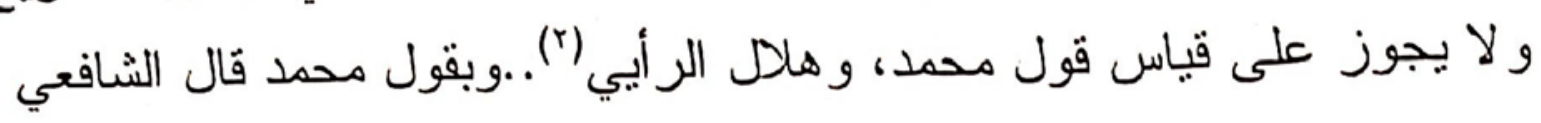

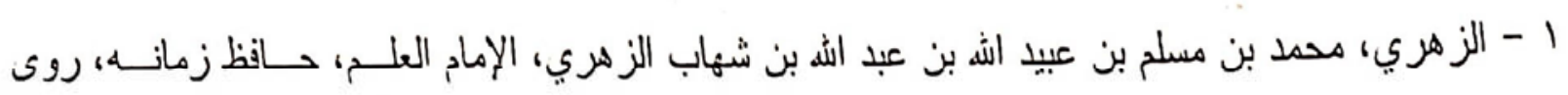

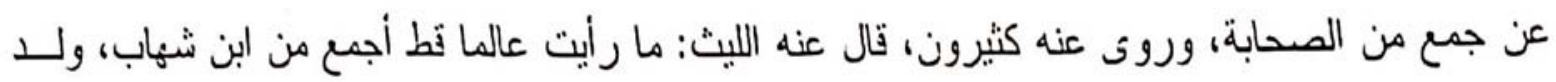

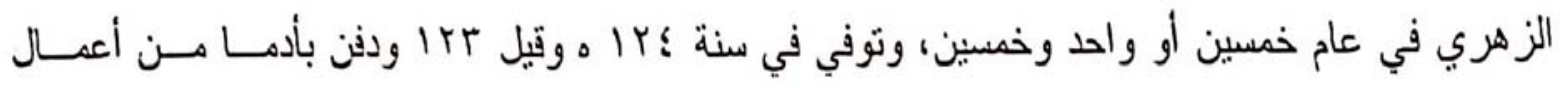

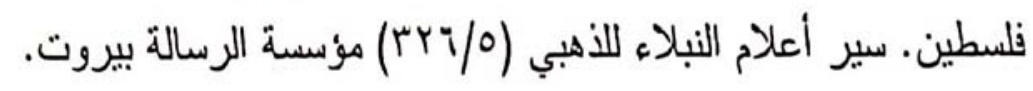

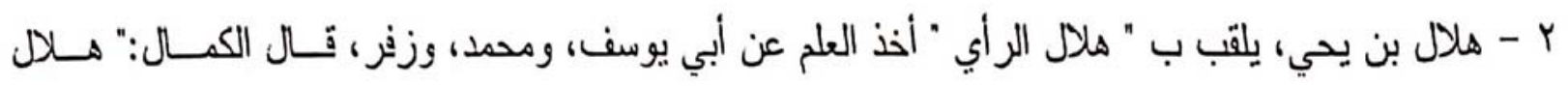

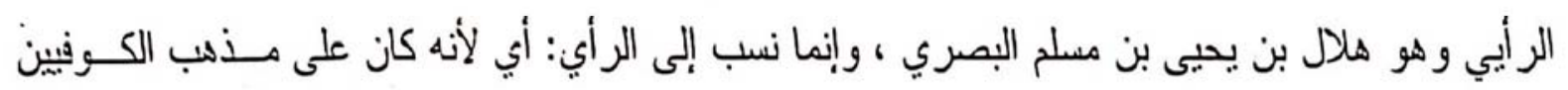

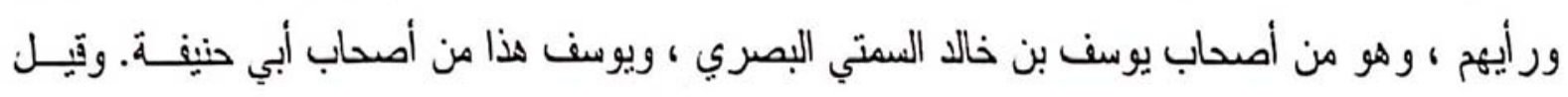

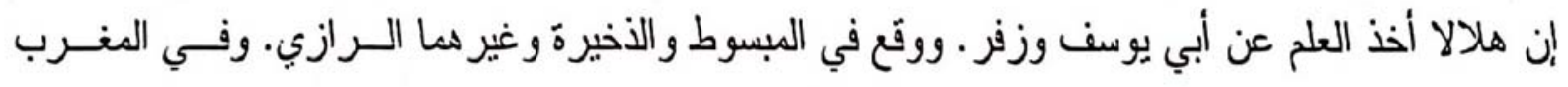

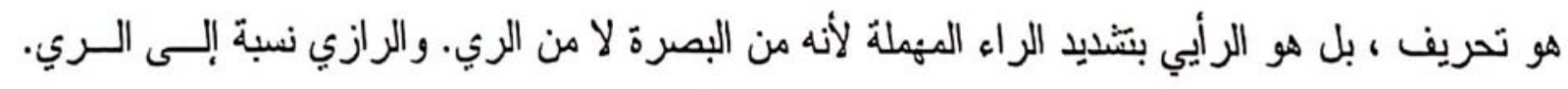

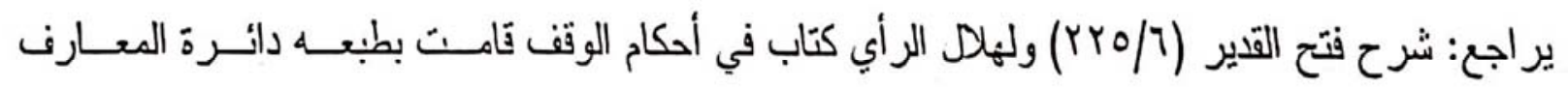

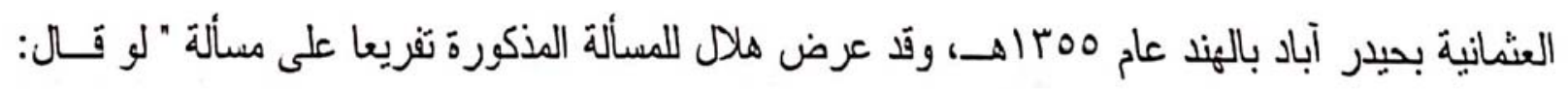

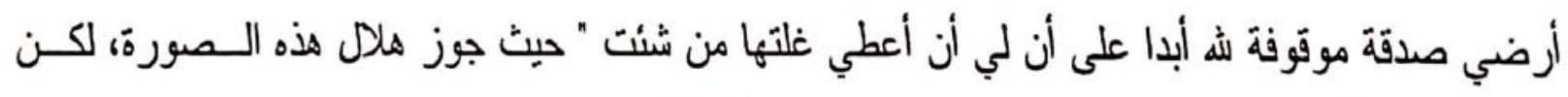

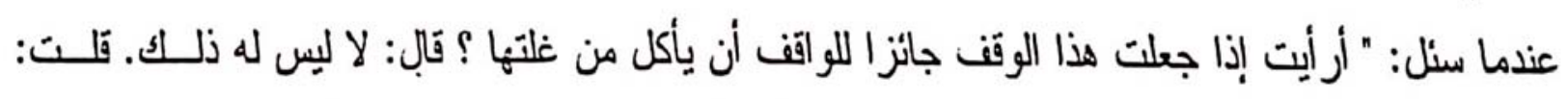

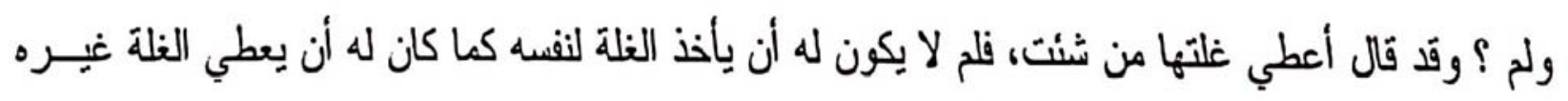

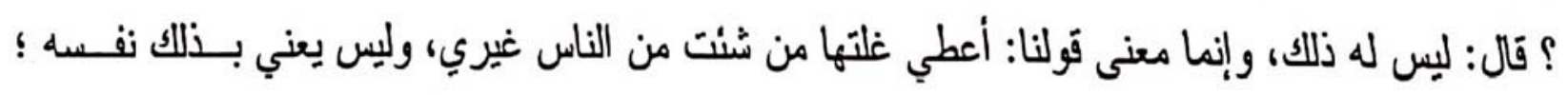

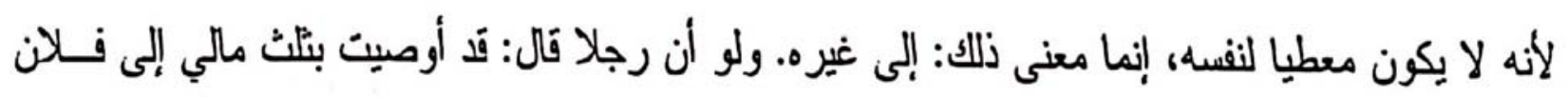

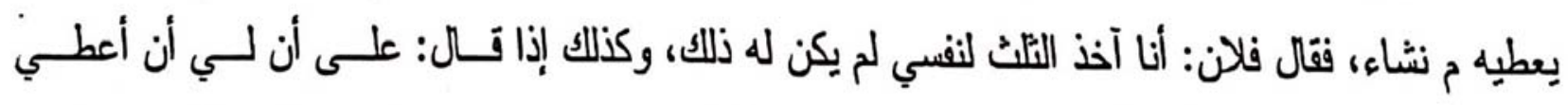

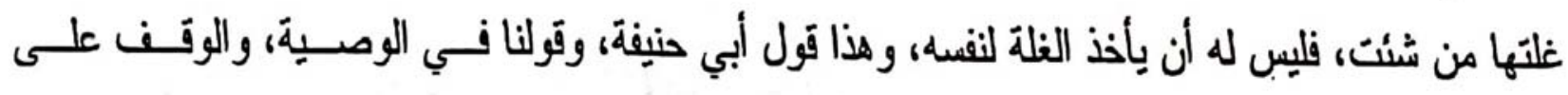

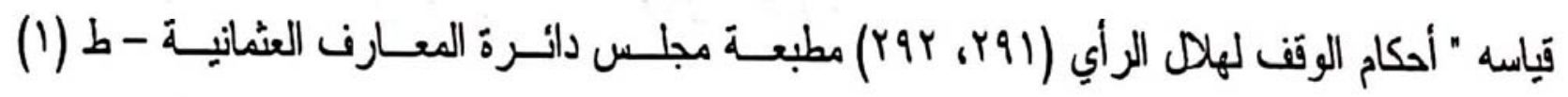


وقال ابن رجب:" يصح عندنا استثناء منفعة العين المنتقل ملكهــا مسن

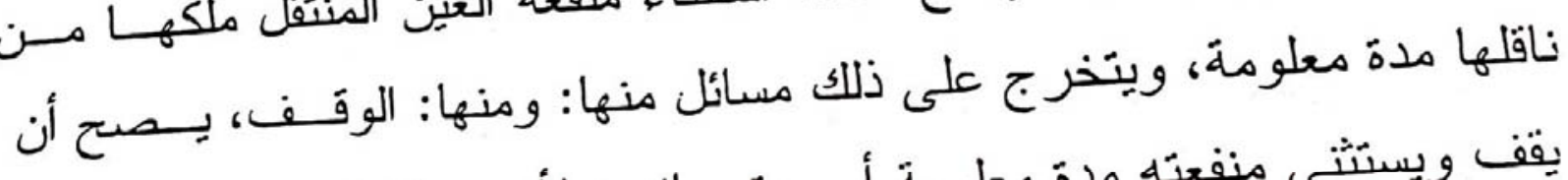

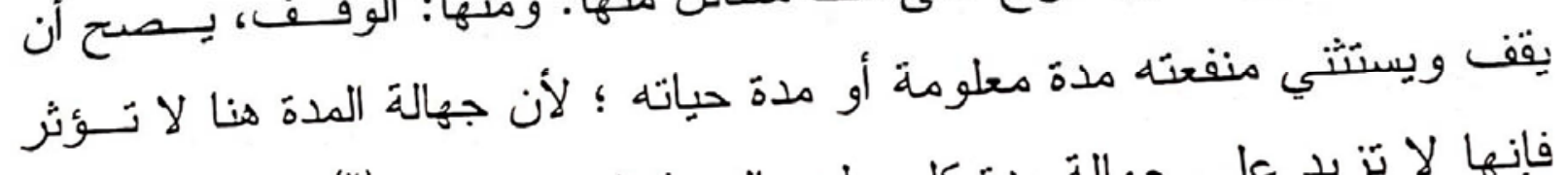

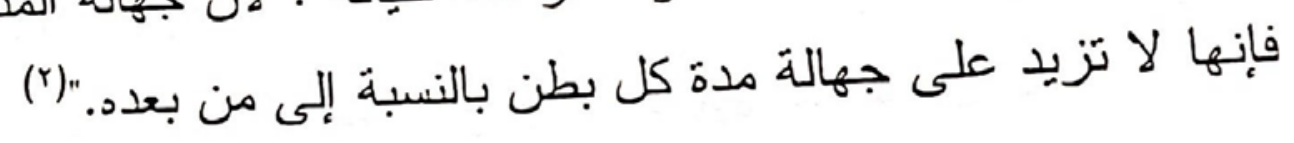

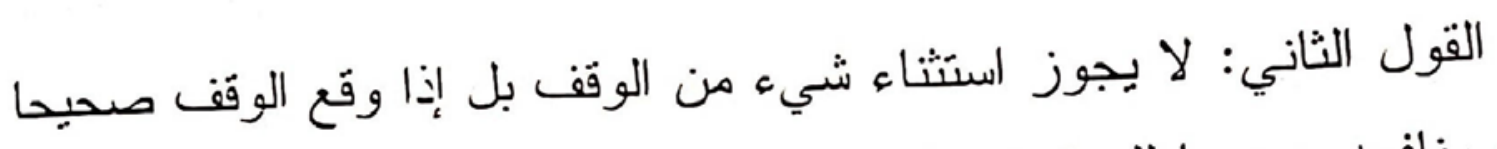

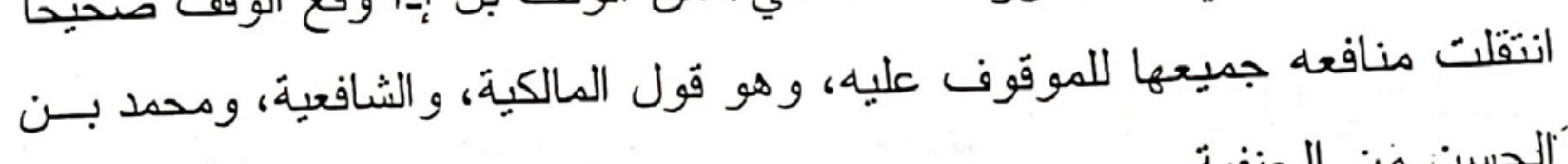
"الحسن sن الحنفية.

جاء في فتح العلي المالك:" ما قولكم: فيمن حبست دارا علــى أولاد ولـــــ

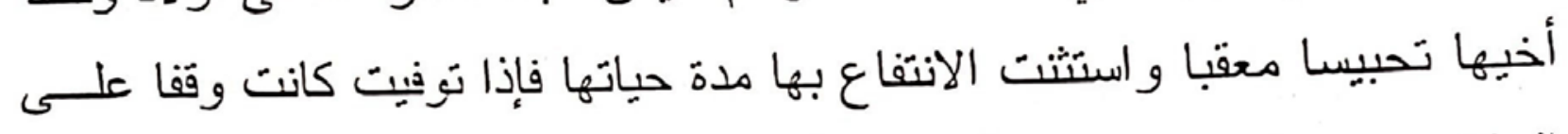

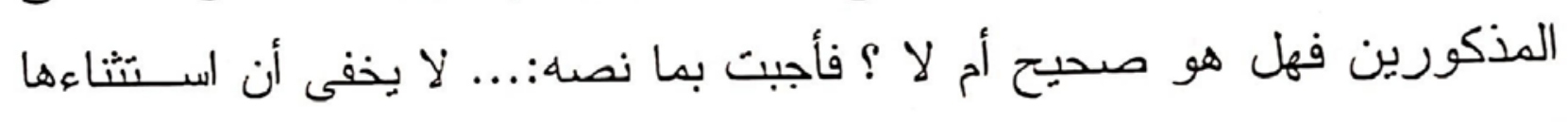

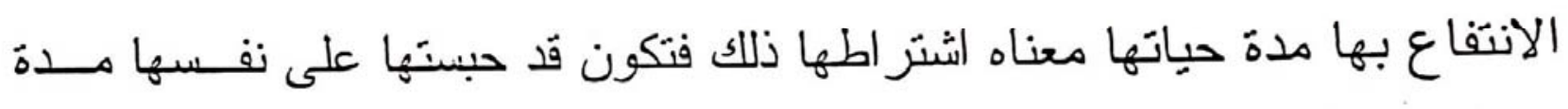

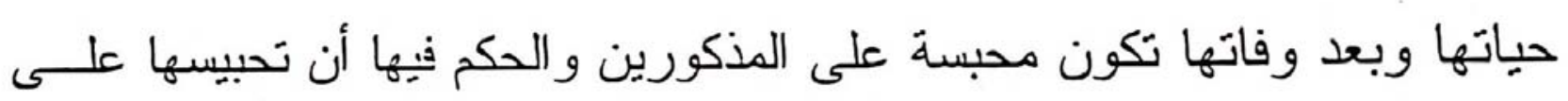

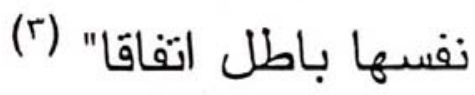
وقال شيخ الإسلام زكريا الأنصاري:" الفو ائد ملك للموقوف عليه فيتصرف

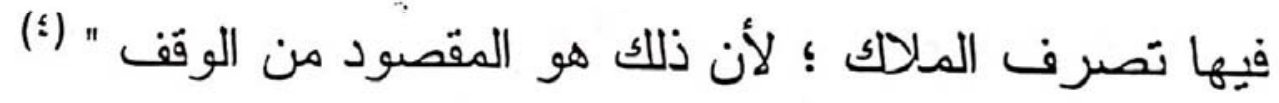

$$
\begin{aligned}
& 1 \text { - شرح فتح القدير (Yro/T) } \\
& \text { r - القو اعد لابن رجب (1). }
\end{aligned}
$$

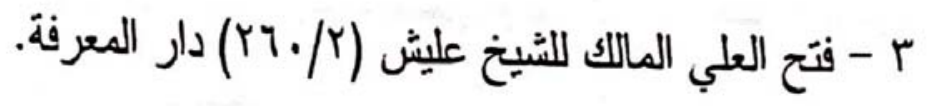

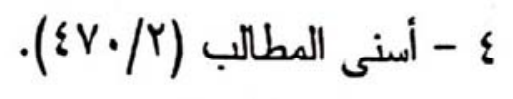


وقَال الكاساني:" هل يُشَرط أن لا يُشرط الو اقَف لنفسه من منافع الوقَسف

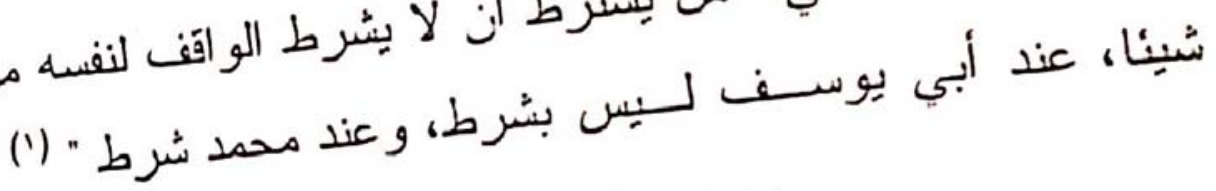

أولا: أخرج الثُبخان عن عبد اله بن عمرسرضي اله عنهما_في وقفية

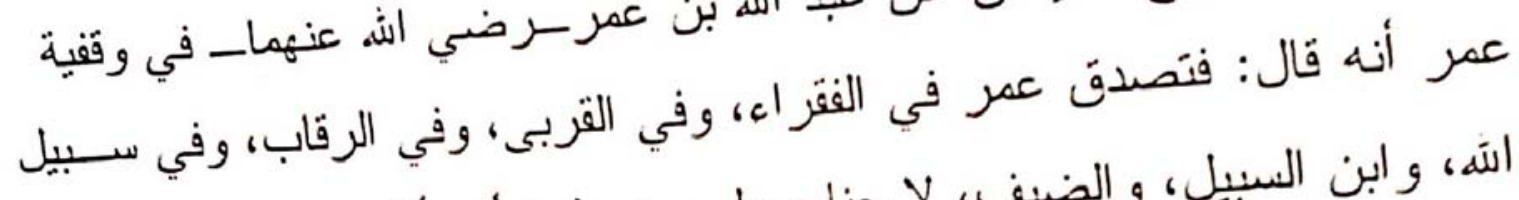

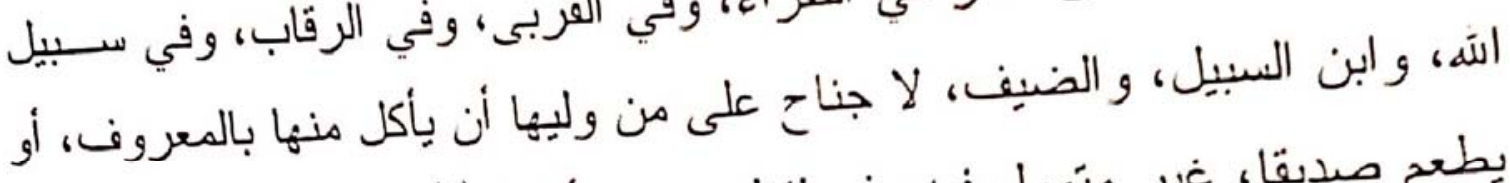

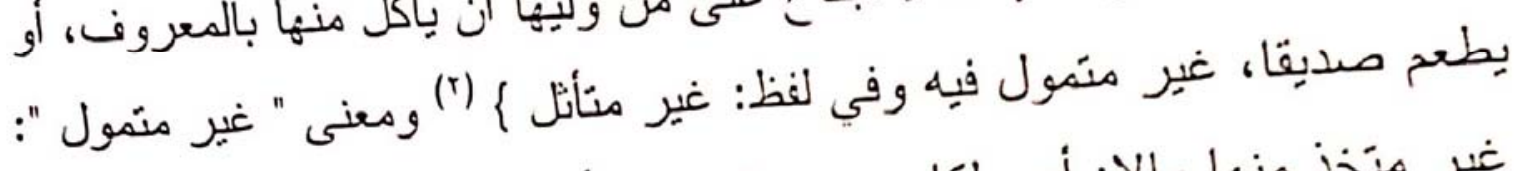

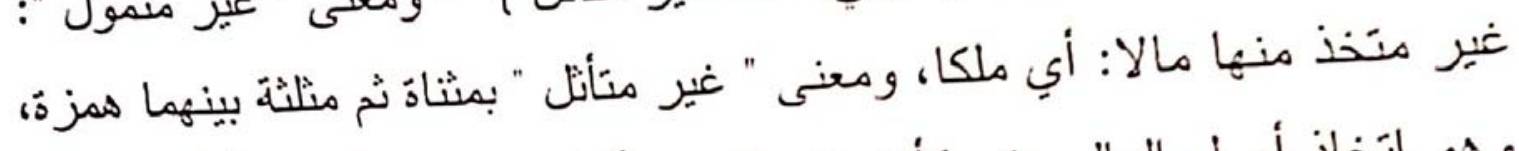

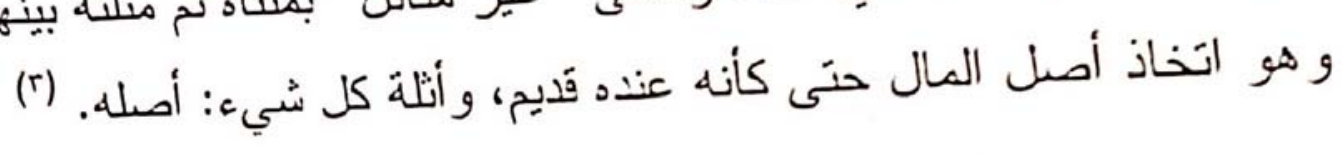

وفي سنن أبي داود بعد أن ساق خبر ابن عمر المتقام: " أخبرني الليــث

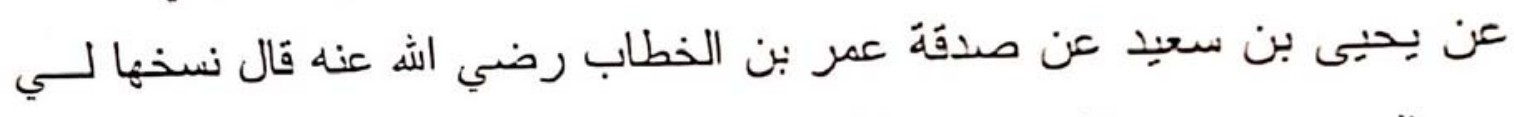
عبد الحمِيد بن عبد الهه بن عبد الهه بن عمر بن الخطاب:" بسم اله الرحمن الرحيم

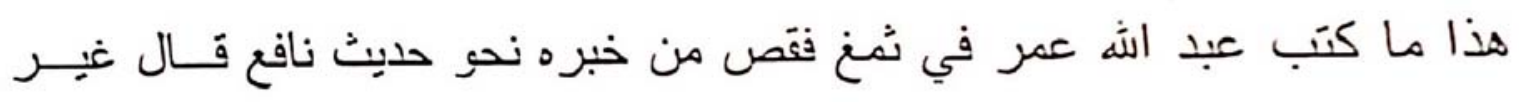
متأتل مالا فما عفا عنه من ثره فيو للسائل و المحروم قَال وساق القصة قال وإن

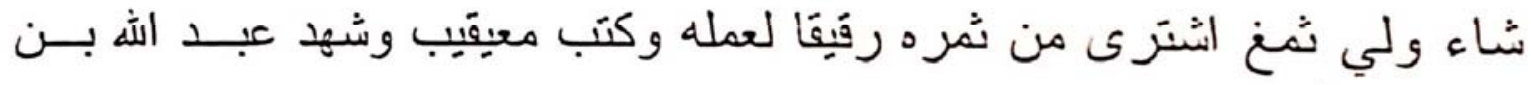
الأرقَم بسم الهه الرحمن الرحيم هذا ما أوصى به عبد الله عمر أمير المؤمنين إن

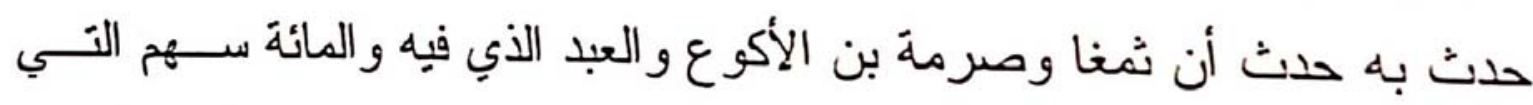
بخيبر ورقِيَه الذي فيه و المائة التي أطعمه محمد صلى الله عليه وسلم بـالوادي

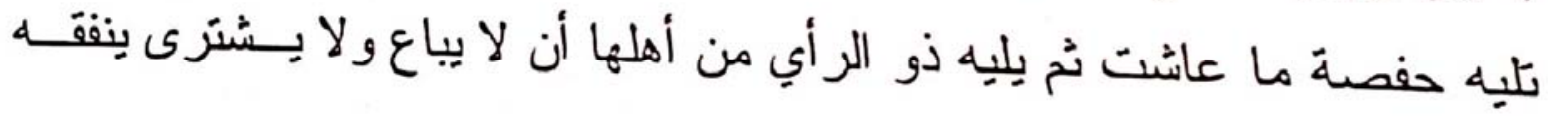

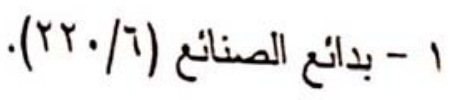

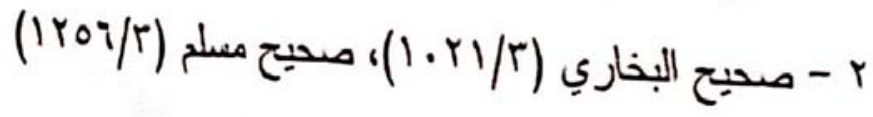
r - نيل الأوطار للشوكاني (YN/0) دار التراث. 
حيث رأى من السائل و المحروم وذوي القربى ولا حرج على من وليه إن أكسل

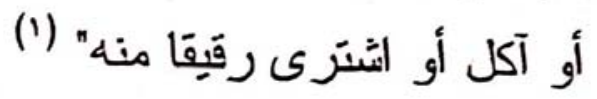

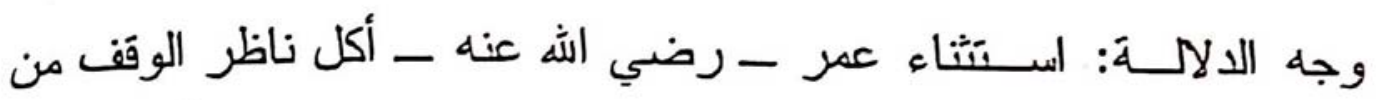

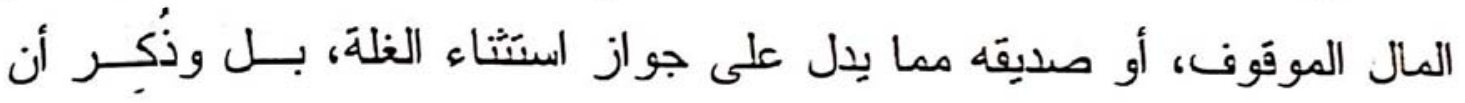

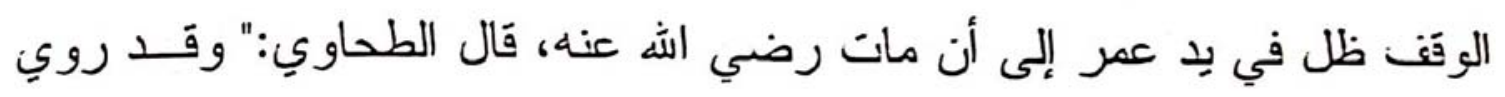

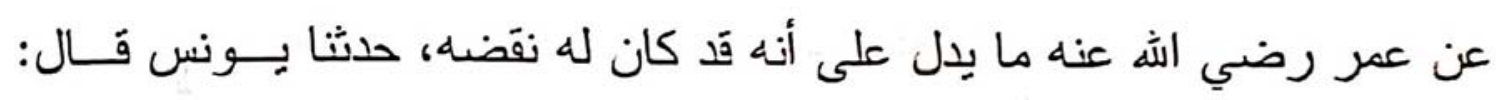

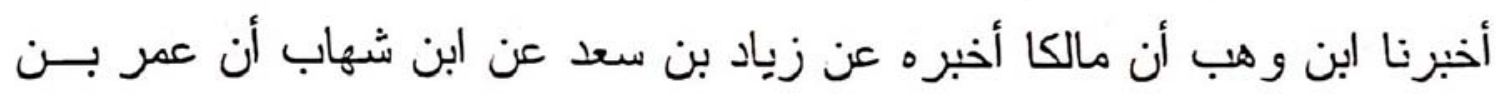

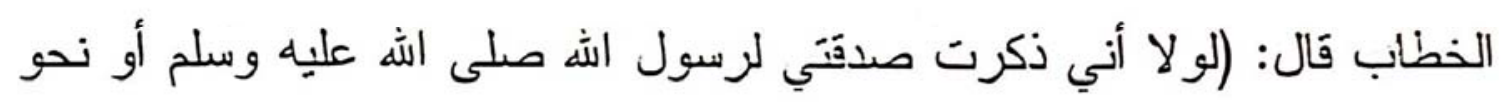

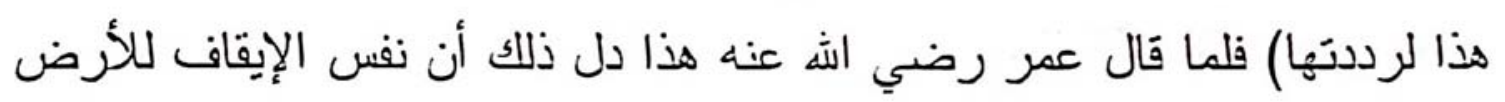

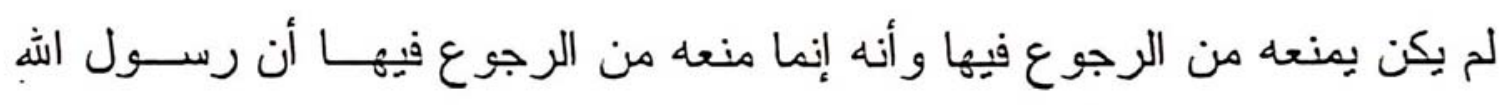

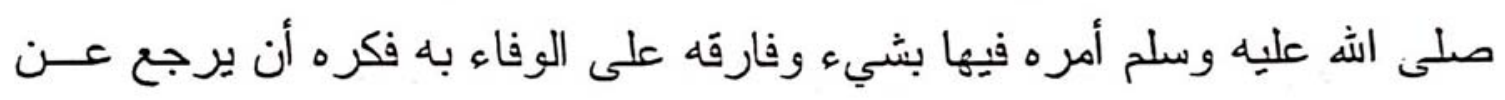

() - زلك)

ثانيا: أخرج ابن أبي شيبة وغيره عن طاوس (r) أن خُجْر المدري(؛) أخبره

$$
\begin{aligned}
& \text { 1 - سنن أبي داود (IV/r) دار الفكر. }
\end{aligned}
$$

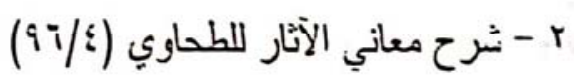

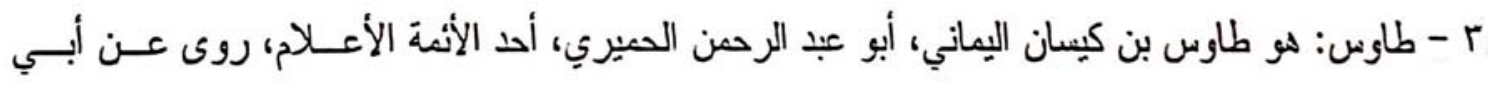

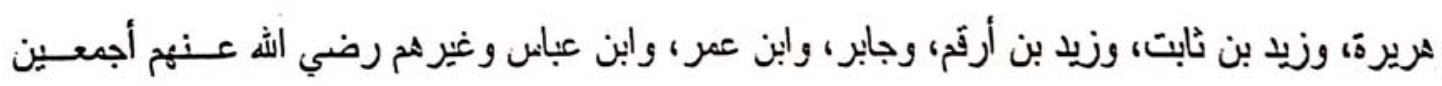

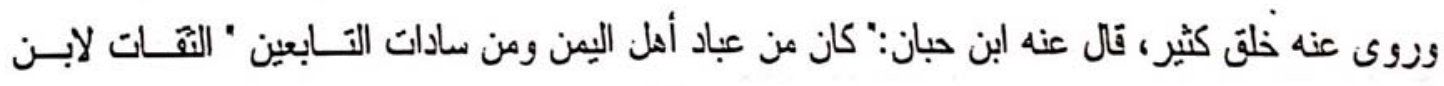

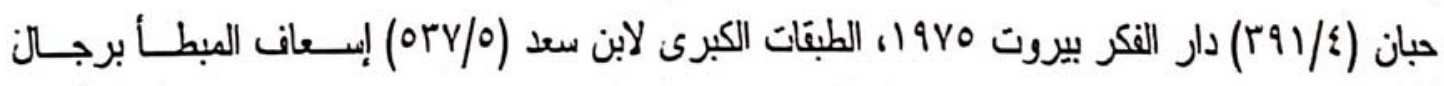

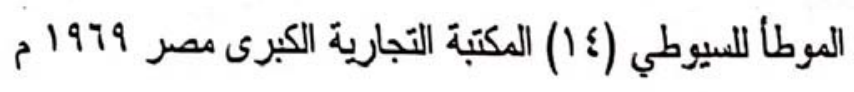

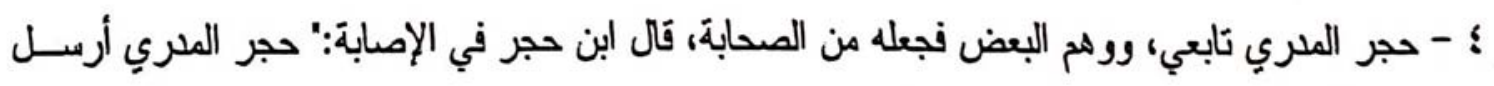

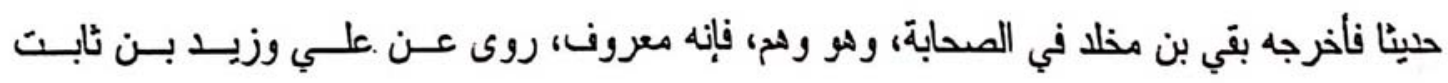

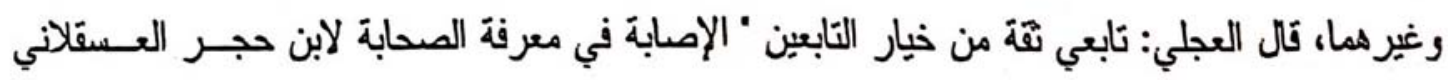

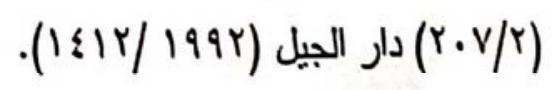




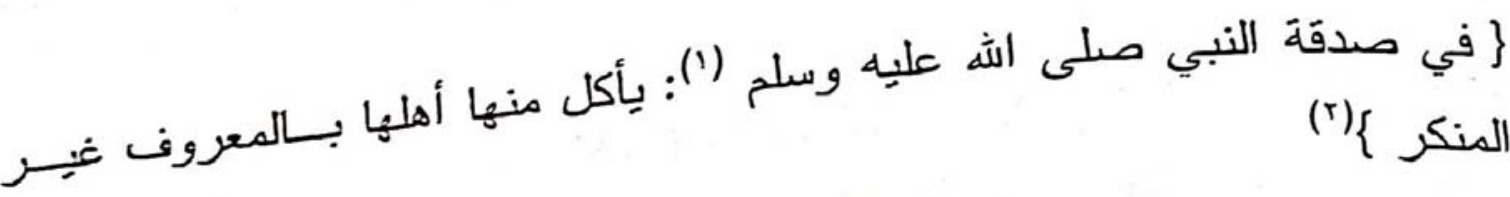

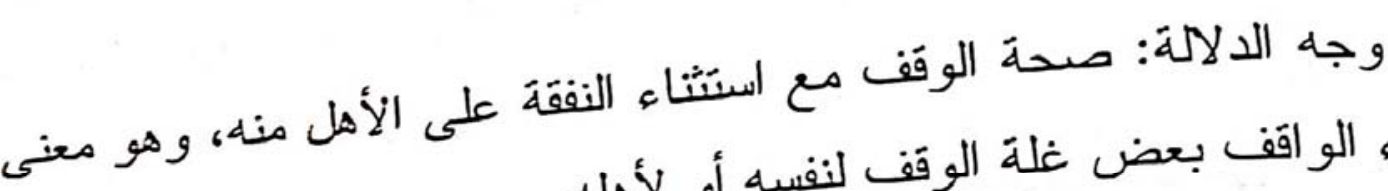
استثناء الو اقف بعض غلة الوقف لنفسه أو لأهله.

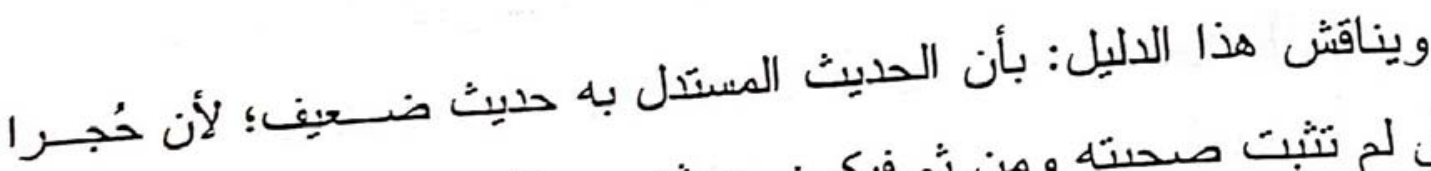
المدري لم تثبت صحبته ومن ثم فيكون حديثّه مرسلا.

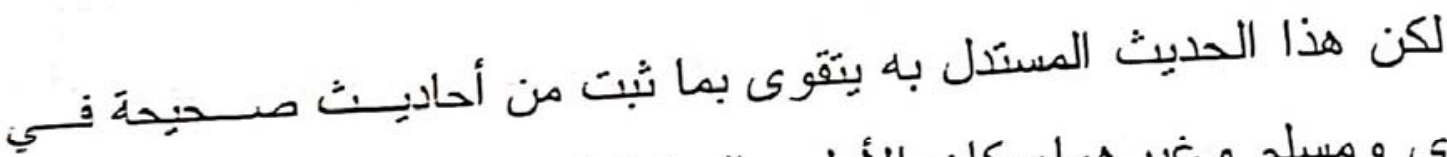

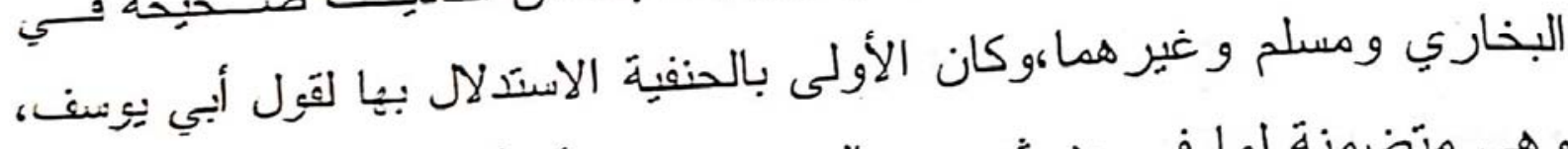

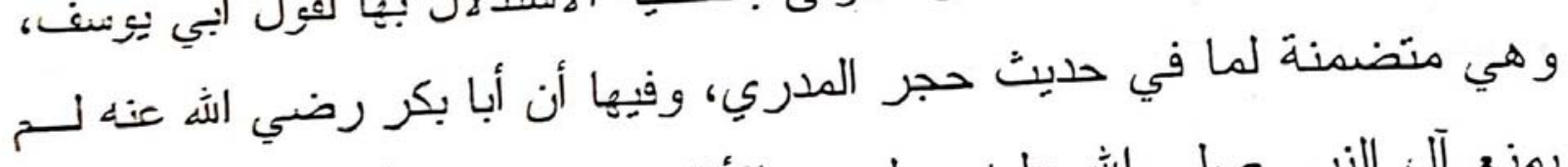

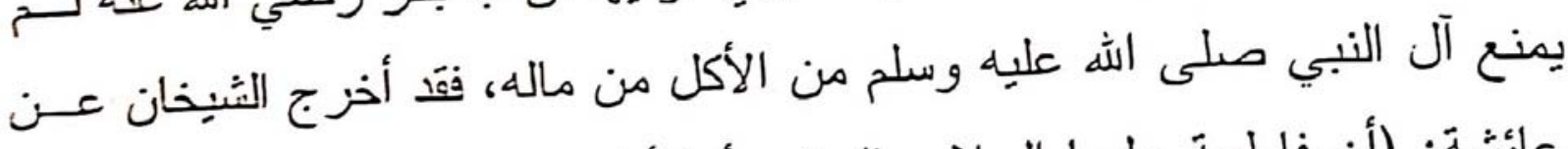

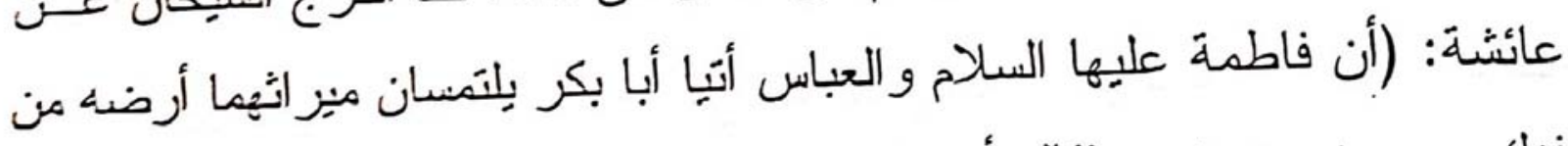

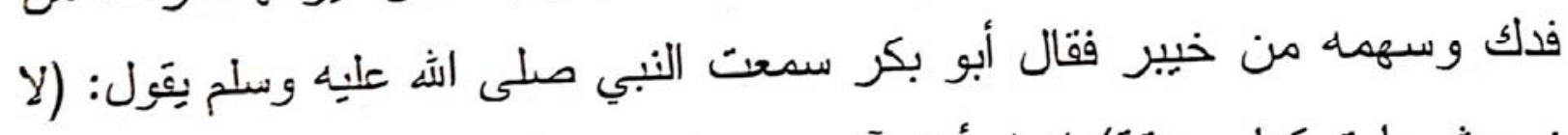

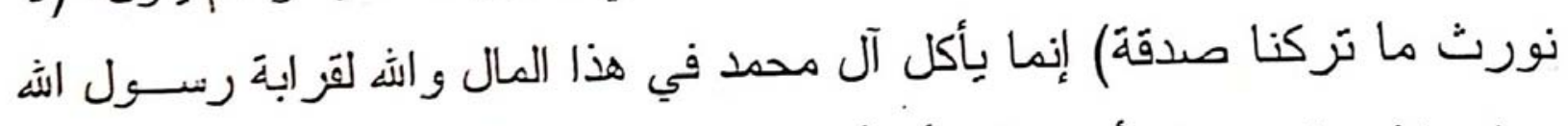

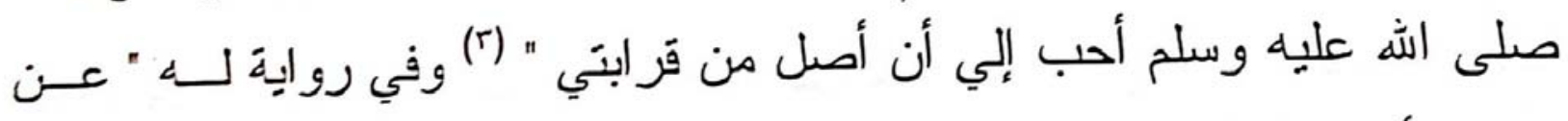
عائشة أن فاطمة عليها السلام بنت النبي صلى اله عليه وسلم أرسلت إلى أبــي بكر تسأله مير اثها من رسول الله صلى الله عليه وسلم مدا أفاء الله عليه بالمديفًَ

1 - صدقة النبي صلى الله عليه هي ما تركه النبي صلى الله عليه وملم بعد وفاتَه وهي مبيده بذيبـز ونـــك، وما تركه النبي صلى اله عليه وسلم لا يورث و إنما يكون صدقَّة ولكن يأكل منها أيله.

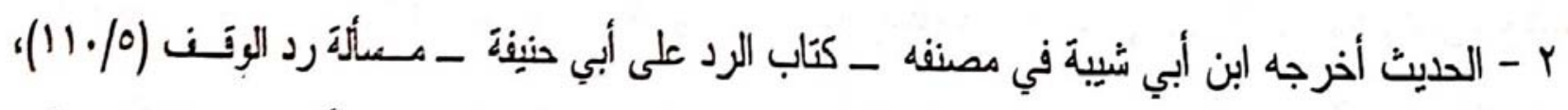

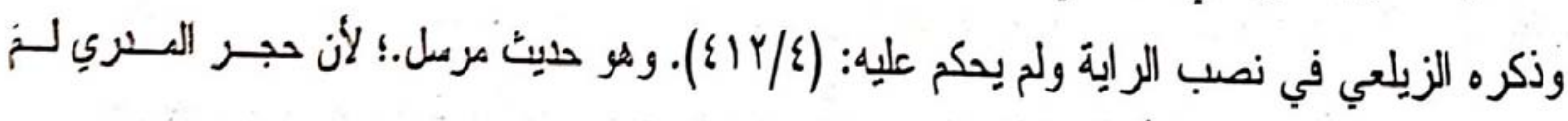
تشبت صحبتها، وفي الاحتجاج بالمرسل خلاف. r - صحيح البخاري (ع / (1) 
وفدك وما بقي من خمس خيبر فقال أبو بكر: إن رسول اله صلى اله عليه وسلم

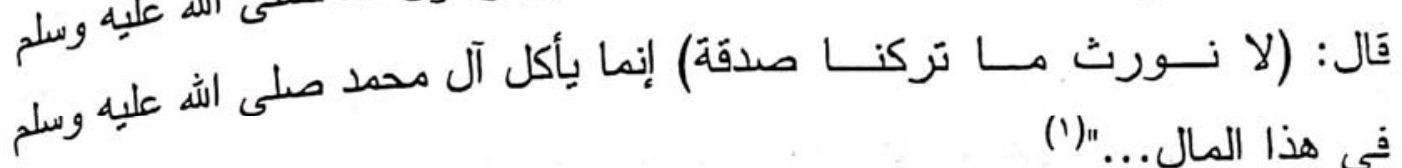
في هذا المال..." (1) ثالثا: روي أن النبي - صلى اله عليه وسلم ـ كان يأكل من صسدقَّه، و الصدقة هنا هي الوقف، جاء في الهداية:" ولأبي يوسف ما روي (أن النبي عليه

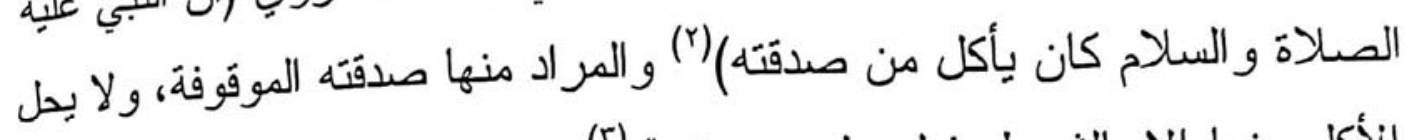
الأكل منها إلا بالشرط، فدل على صحته " (r) ويناقش هذا: بأن الحديث لم يشبت، وهو غريب بهذا اللفظ، وربما بكــون أكل النبي صلى اله عليه وسلم من سهمه بخيبر وفدك في حياته، وهذا السهم لم يكن صدقة إلا بعد وفاته صلى اله عليه وسلم. رابعا: أن الوقف إز الة الملك إلى اله تعالى، فإذا شرط بعض المنافع لنفسه أو كلها فقد جعل ما صار مملوكا لله تعالى مملوكا لنفسه، ولم يجعل ملك نفسه لنفسه، و هذا جائز، فإنه إذا وقف أرضا مسجدا جاز له الصلاة فيه، وإذا وقفهـا مقبرة جاز له أن بدفن فيها، و إذا وقف سبيل ماء جاز له أن يشرب منه، وهكذا، قَال ابن قدامة:" لأنه إذا وقف وقفا عاما، كالمساجد، و الـسقايات، و الرباطــات،

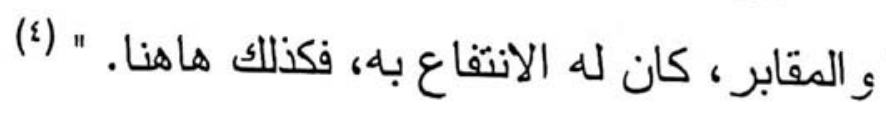

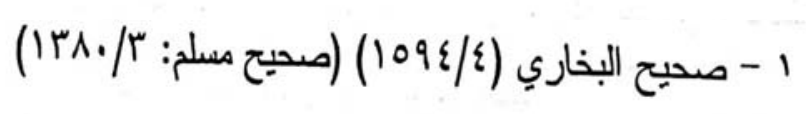

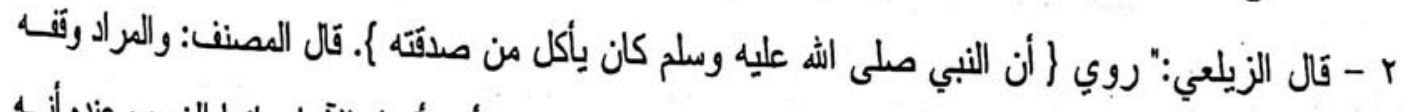
؛ قلت: غريب أيضا " مصطلح " غريب " عند الزيلعي لا يقصد به أحد أقسام الآحاد، إنما الغريب عنده أنس النه ليس بمعرون، وقد حاولت جاهدا الوقون عليه في كثير من المراجع الديثية فلم أجده. r - العناية شرح الهداية للبابرتي (T/TrYr) دار الفكر. ؛ - المغني لابن قدامة (ror/0) 
خامسا:مقصود الوقف القربة، وفي صرف الو اقَف من وقفه علــى نفسـه

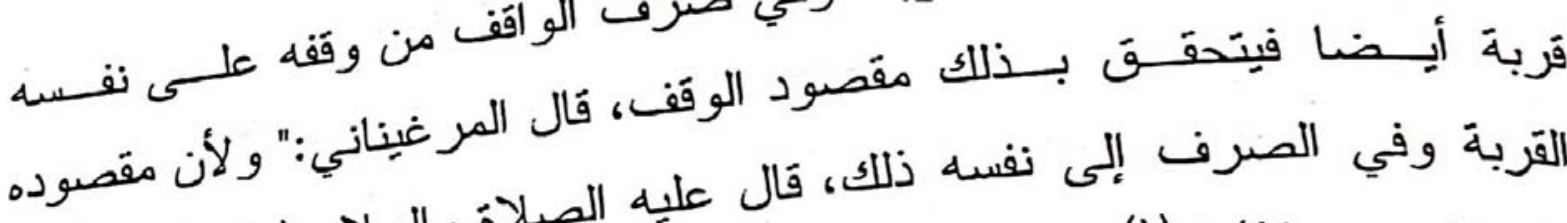

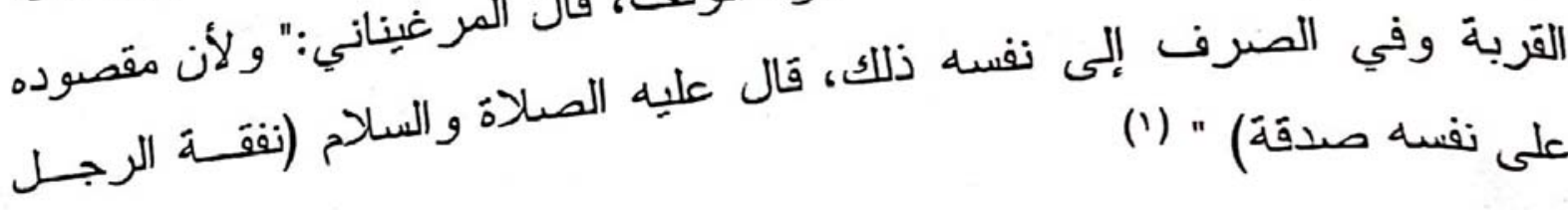
سادسا: القياس على جواز استفادته من وقفه إذا وقفه وقفا عاما كالمساجد و المقابر فللو اقف أن يصلي في المسجد، وأن بدفن في المقبرة. وجه فن قال بعدم الجواز :

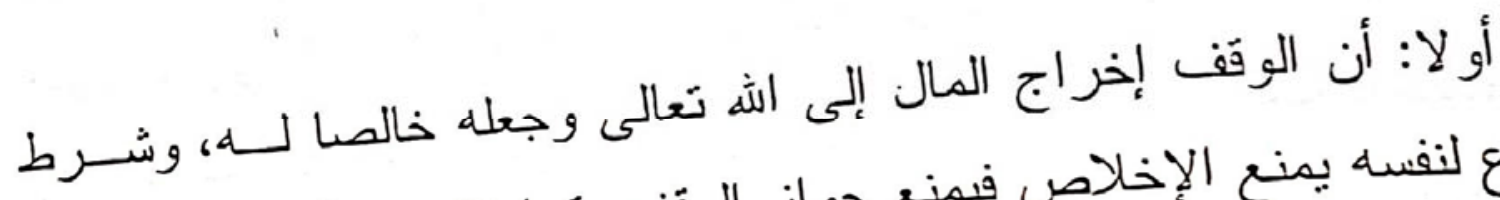

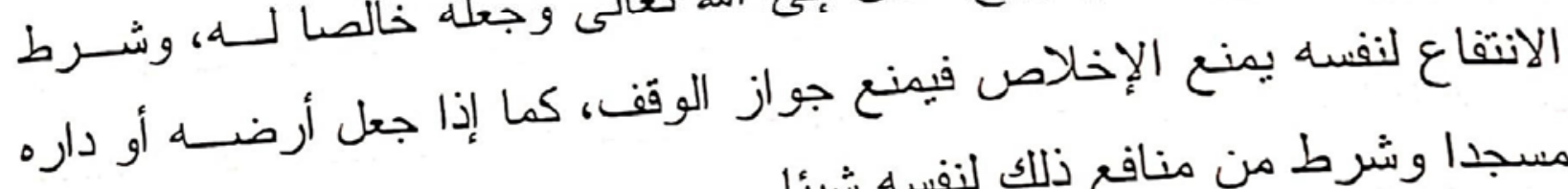
مسجدا وشرط من منافع ذلك لنفسه شيئا.

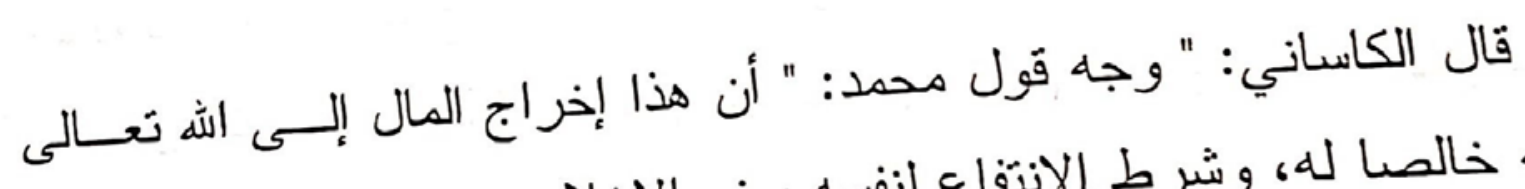

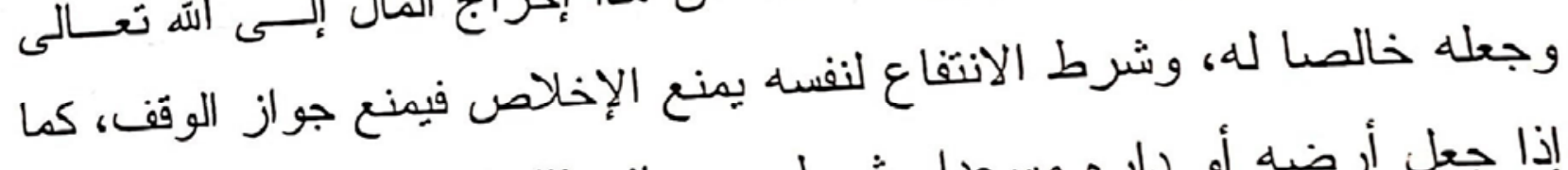

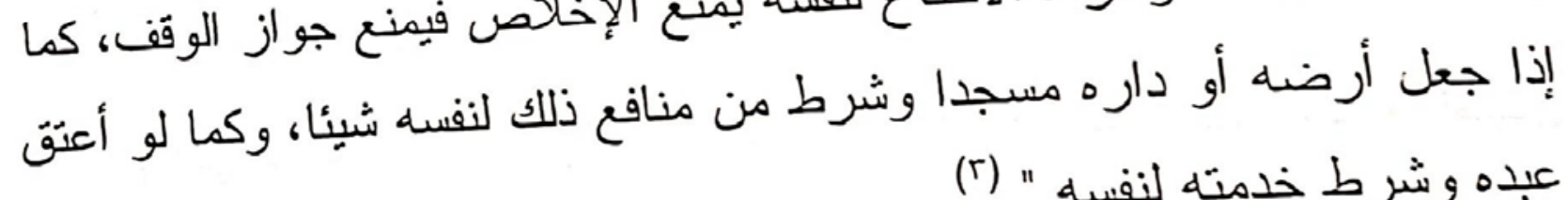

عبده وشرط خدمته لنفسه " (r)

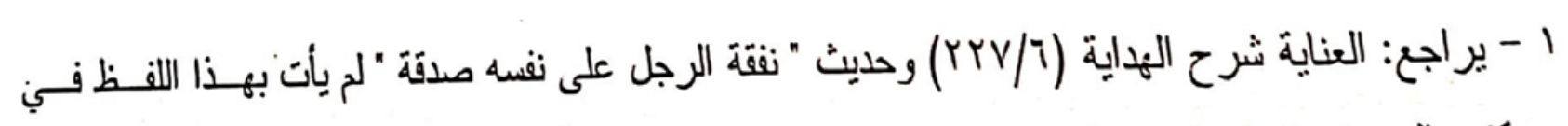

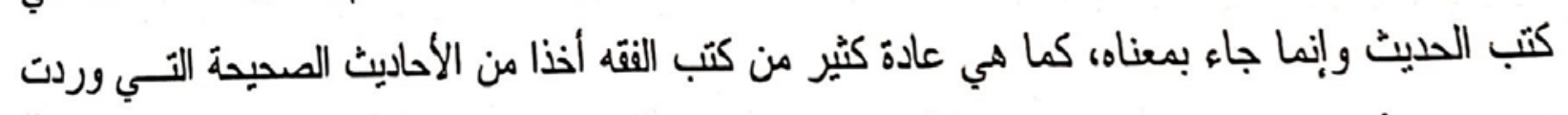
في اعتبار أن ماينفقه الرجل على نفسه وأهله وولده ودابته صدقة من الصدقات. ومنه ما رواه الحاكم وابـن حبان من حديث أبي سعيد الخري بلفظ: " أيما رجل كسب مالا من حلال ، فأطعم نفسه وكساها ، فــن دونه من خلق اله ، فان له به زكاة \{ قال الحاكم: هذا حديث صحيح الإسناد ولم يخرجاه، المستركلك للــاكم

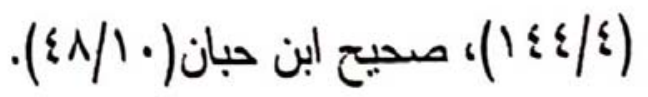

$$
\begin{aligned}
& \text { r - المغني - موضع سابق. }
\end{aligned}
$$

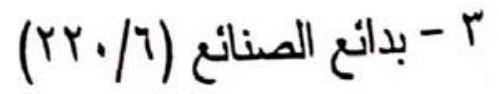




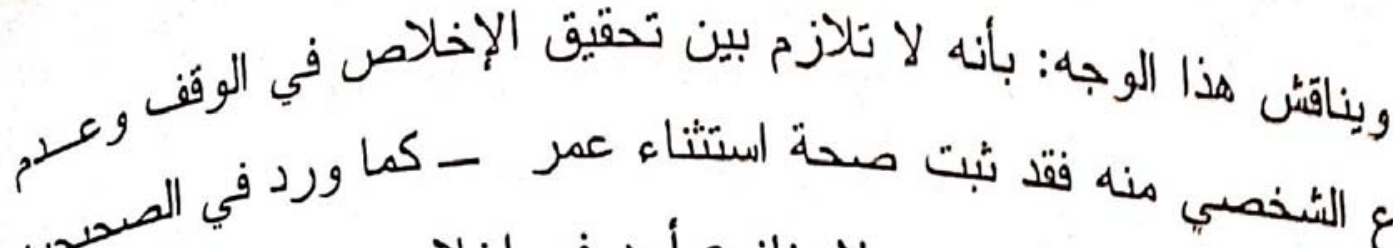

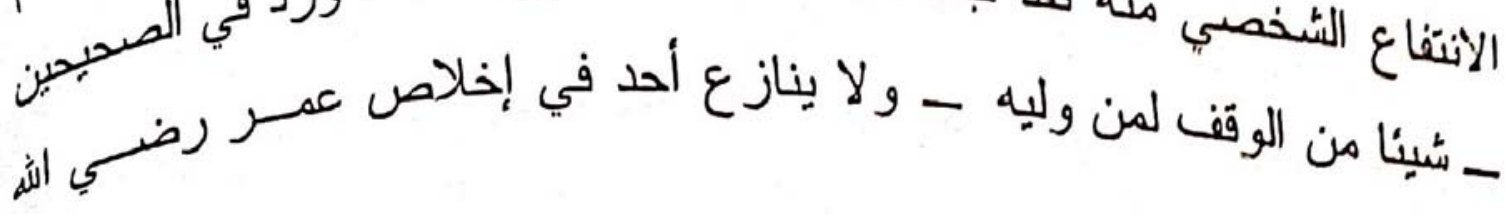

عناه.

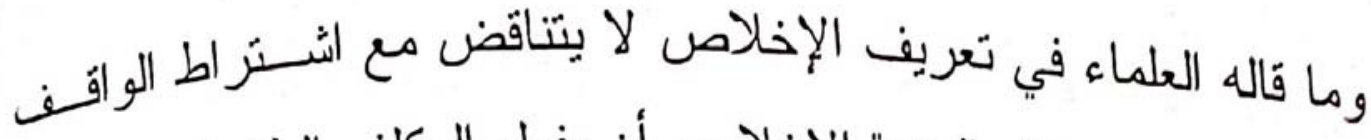

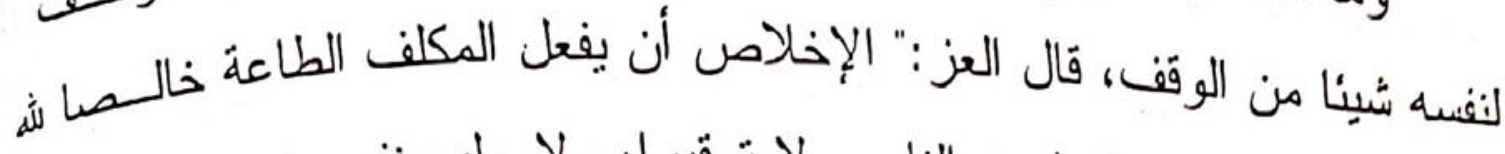

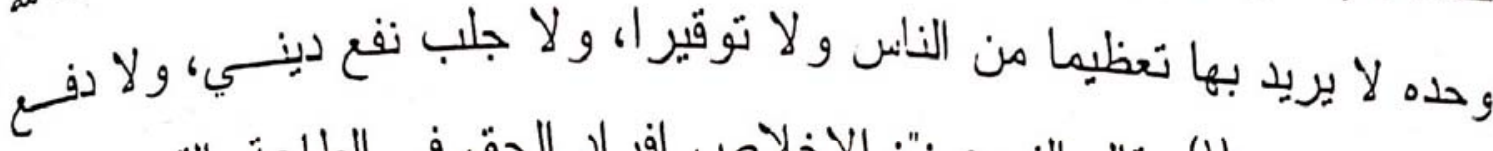
ضرر دنيوي "(') وقال النووي:": الإخلاص إفراد الحق في الطاعة بالقصد، وهو

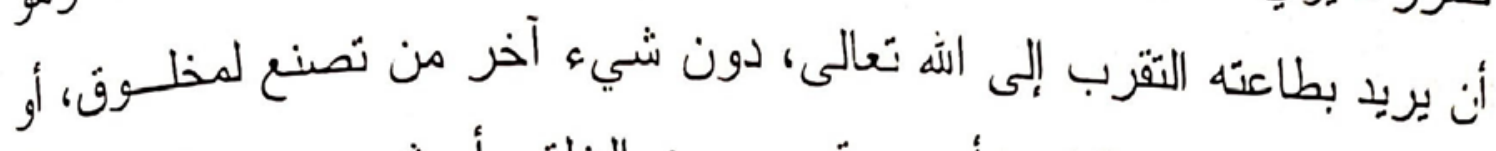

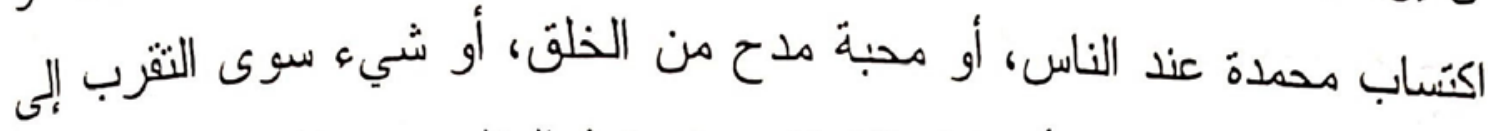
اله تعالى. قال: ويصح أن يقال الإخلاص تصفية العقل عن ملاحظــة الخلــنق

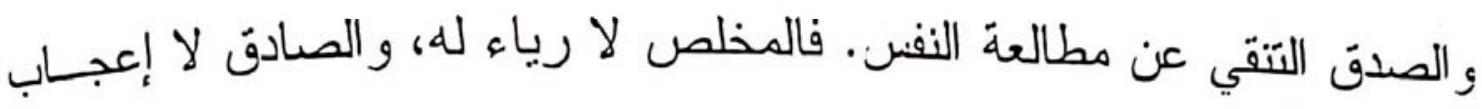

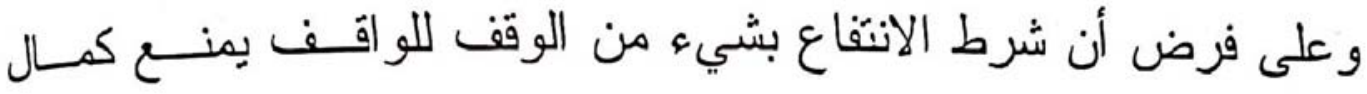

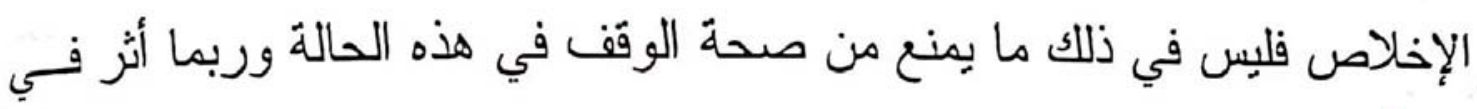

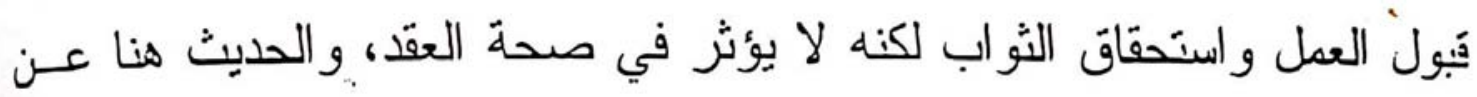
صحة العقد لا عن تحصبل الثو اب.

ثانيا: أن مقصود الوقف تمليك المنافع و الفو ائد للموقوف عليـه،، وشـرط

الو اقف استثناء منفعة الوقف مخالف لذلك فلا يجوز شرطه.

$$
\begin{aligned}
& 1 \text { - بواعد الأكام في مصالح الأنام (1/T؛ } \\
& \text { r r المجوع شُرح المهنب (I/Ir) }
\end{aligned}
$$

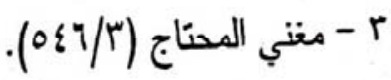


قال الرملي "ومنافعه ملك للموقوف عليه؛ لأن ذلك مقصوده يستوفيها بنفسه

وبغيره " (1) (1)

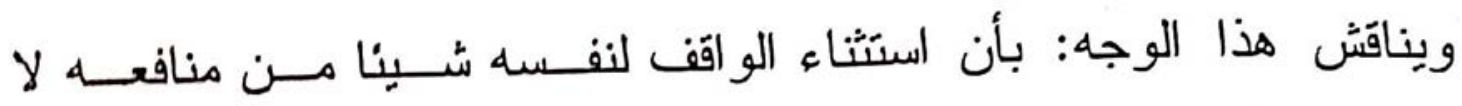

يتعارض مع تمليك الموقوف عليه للوقف، وقد صـح مدل ذلك في عقود أخــرى كالبيع إذ بصح مع استثناء شيء معلوم، وقد ورد صحة البيع مع استثناء المنفعة لمدة معلومة على خلاف بين العلماء في تفاصبل المسألة وفي حديث جابر المثفق عليه ما يدل على الصحة " كان على جمل له قد أعبا. فــأر اد أن بـسـيبه قــال: فلحقني النبي صلبي الهه علبه وسلم فدعا لي، وضربه. فسار سير الم يسر مثلـــه، فقال: بعنيه بأوقية قلت: لا. ثم قال: بعنيه فبعته بأوقية، و اشترطت حملانه إلـى وصى أهلي، فلما بلغت أتيته بالجمل، فنقدني ثمنه، ثم رجعت فأرسل في أثري. فقـال: أنز اني ماكستك لآخذ جملك ؟ خذ جملك ودر اهمك. فهو لك " (r) ثالثا: يشترط قبض الموقوف لصحة الوقف، و اشتر اط الو اقف الغلة لنفـسه مناف لهذا الشرط فلا يصح. (r) ويناقش هذا: أن قبض الموقوف عليه للوقف محل خلاف بـين العلمــاء،

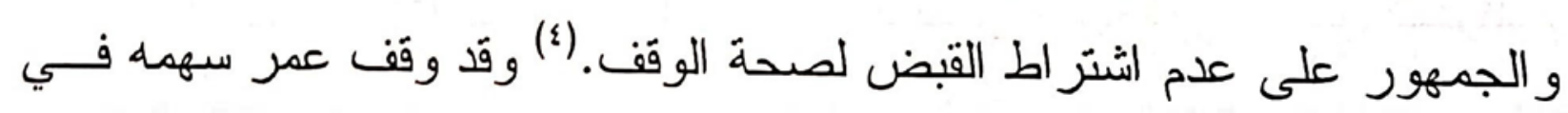
خيبر وهو مشاع وقد أمره النبي _ صلى الله عليه وسلم - به. (o)

1 - نهاية المحتاج إلى شرح المنهاج (r^9/0)

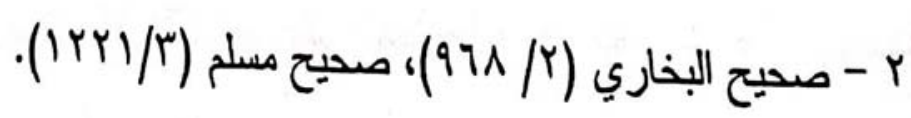
r - شرح فتح القدير (ro/T) ـ - المغني لابن قدامة:(rVo/0). 0 


\section{ويظهر رجحان القول الأول لما ذكر من أدلة ولما يلي: ـ}

أ - اعتـــدادا بـشرط الواقف، وهو شرط لا يخالف نصا و لا إجماعا،

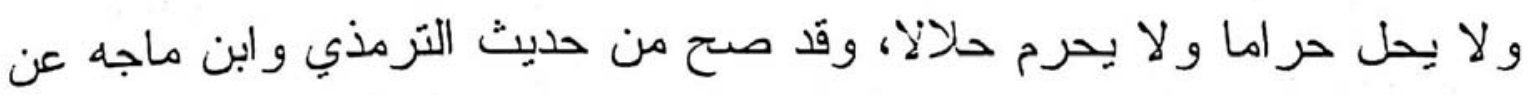
عمرو بن عوف وفيه من زبِّدة الترمذي (المسلمون على شروطهم إلاشسـرطا

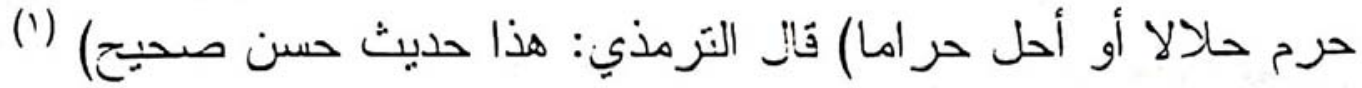
ب - الو اقف منبر ع ومحسن، و الأصل حث الناس على التبر عات وفـنتح

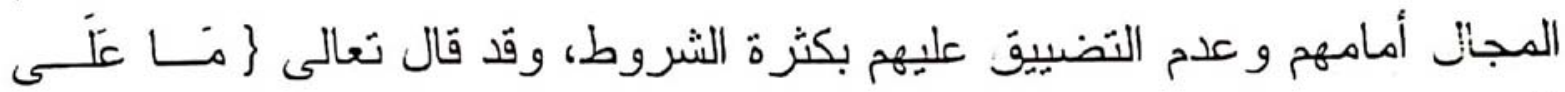

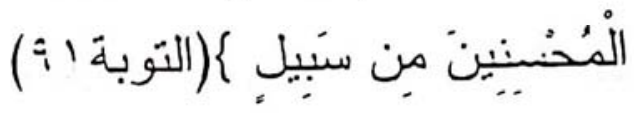
قَال الجصاص:" كما على المحسنين من سبيل \{ عموم في أن كل من كان

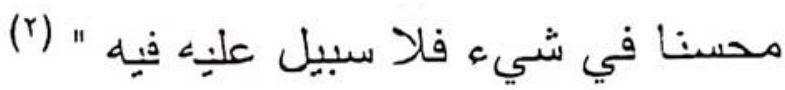

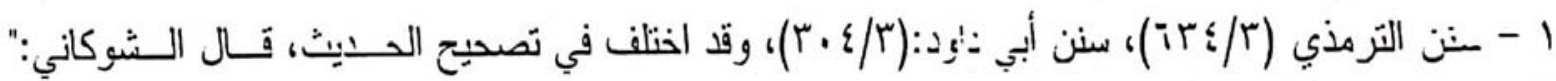

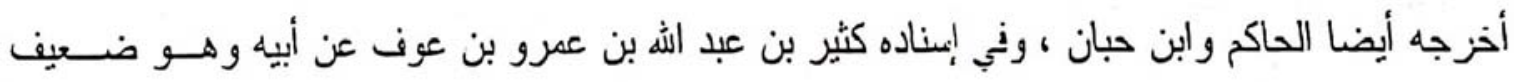

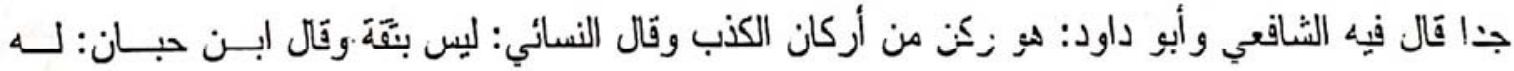

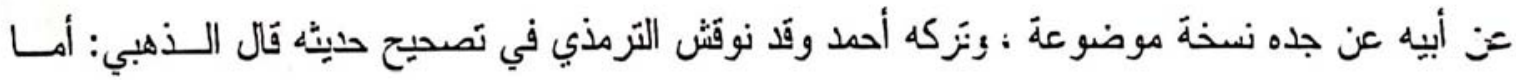

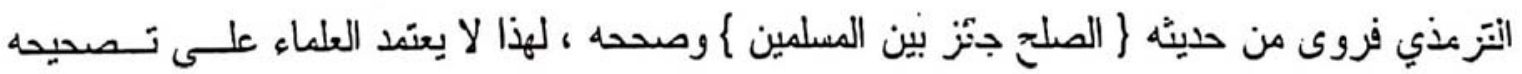

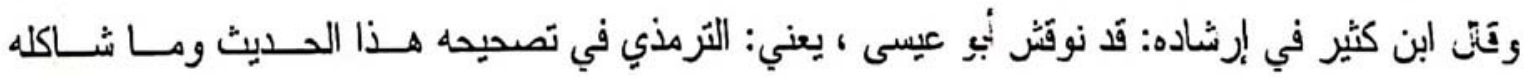

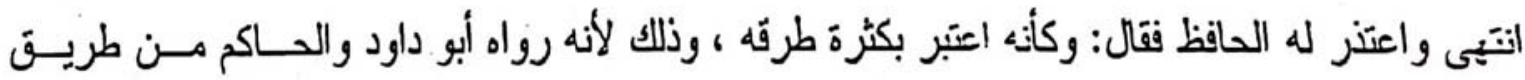

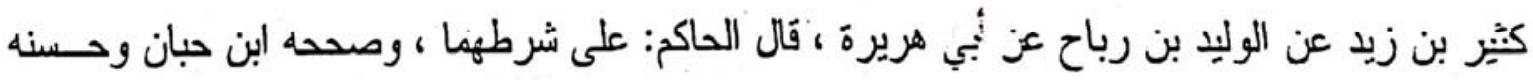

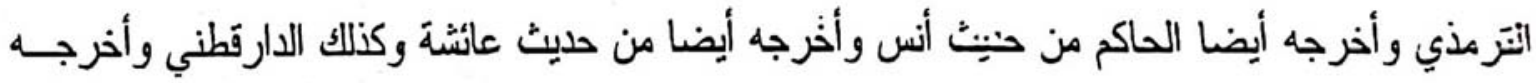

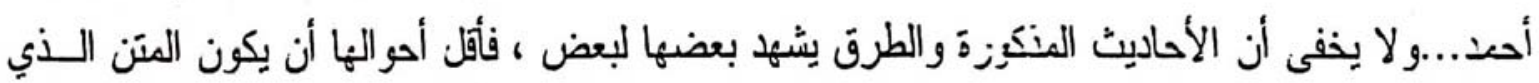

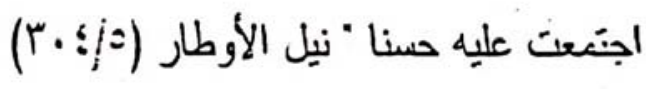
r - r أحكام القر آن للجصاص (r)/r) 
ج - تجويز كثير من الفقهاء استثناء منفعة المبيع بضوابط، وهو أنشد من

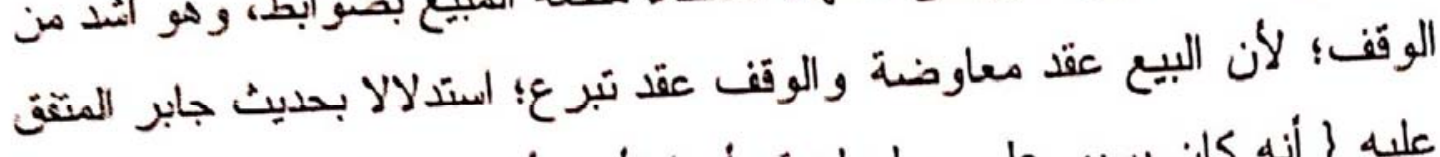

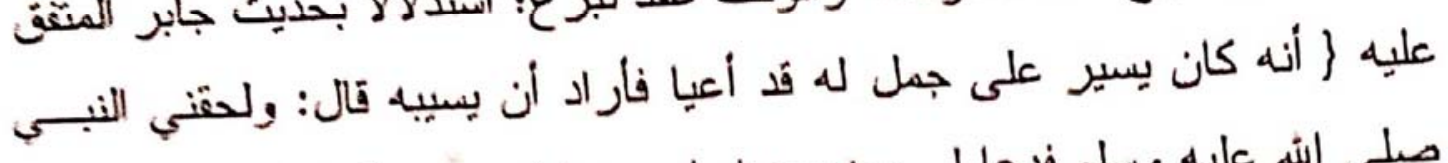

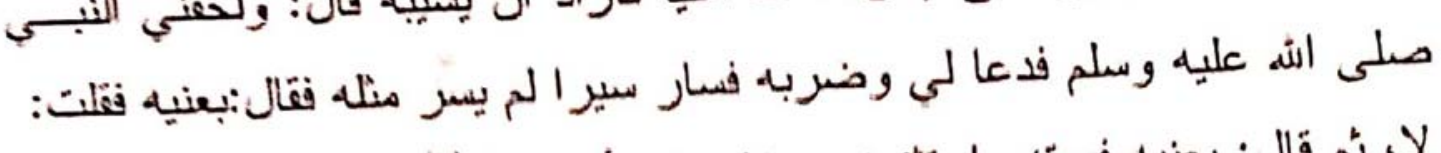

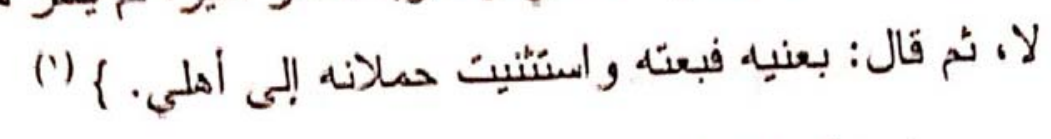

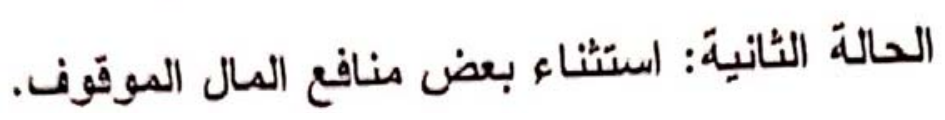

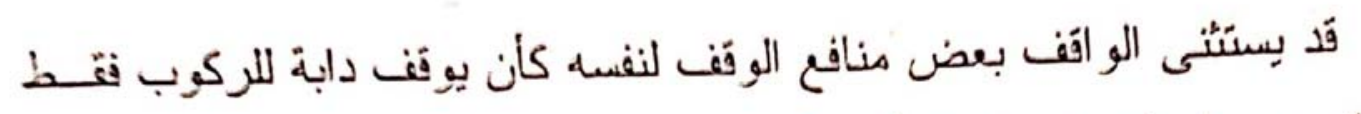

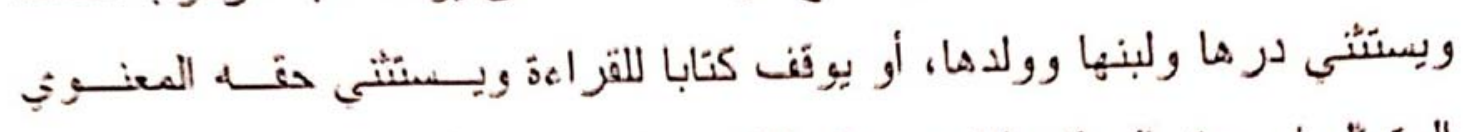

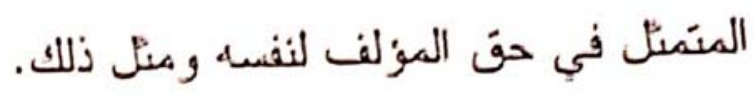

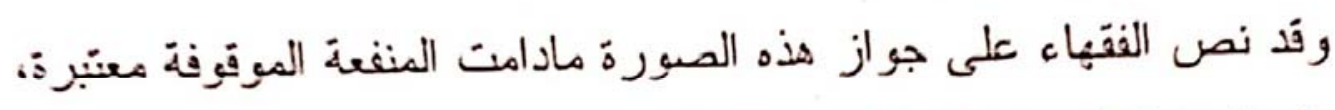

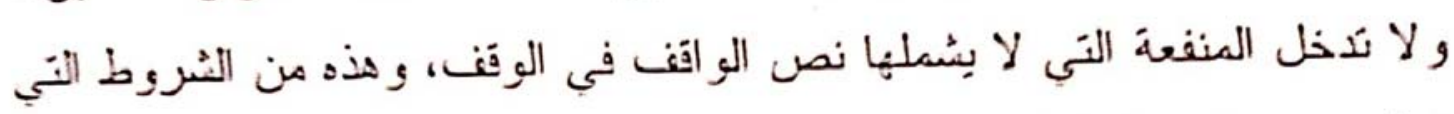

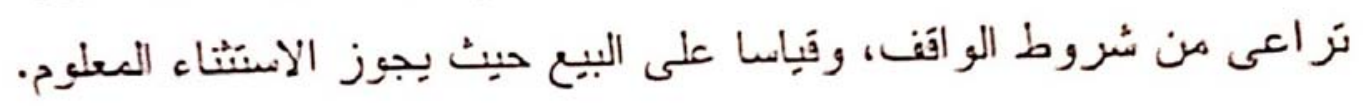

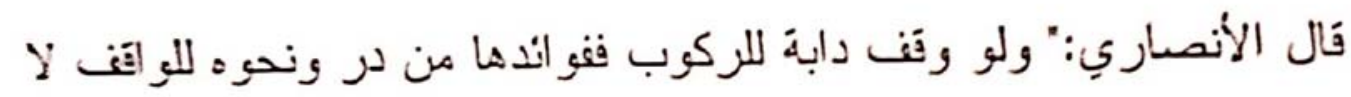

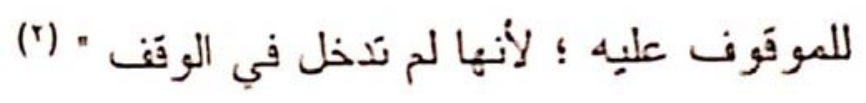

$$
\begin{aligned}
& \text { الحالة الثَالثة: استُناء منافع الوقف أبدا. }
\end{aligned}
$$

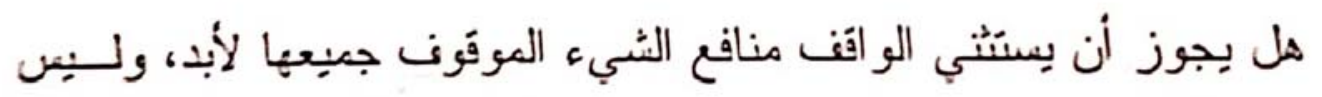

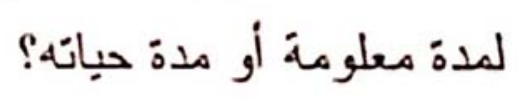

الذي بظهر من كلام المجوزين لاستثناء المنافع لمدة معلومة أو مدة حبــاة

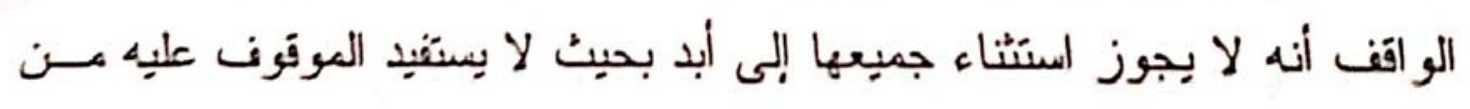

$$
\text { r - } 1 \text { - سبق نغريجه. }
$$




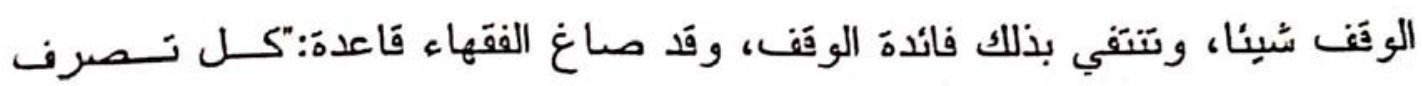

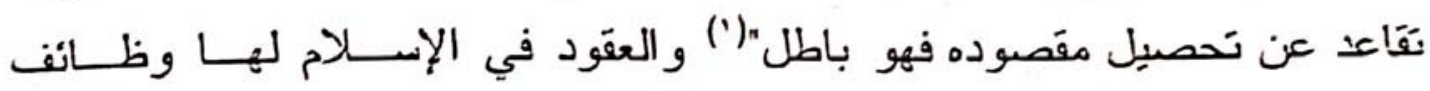
ومقاصد، ويجب أن تكتزه عن العبث. بكن.

المطلب الثالث: وقف المنفعة دون أصلها.

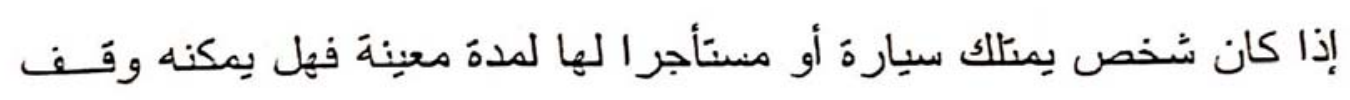
زكيب هذه البيارة لبعض الطلاب، أو لنقل المرضى ونحو ذلك، ولو ألف مؤلف

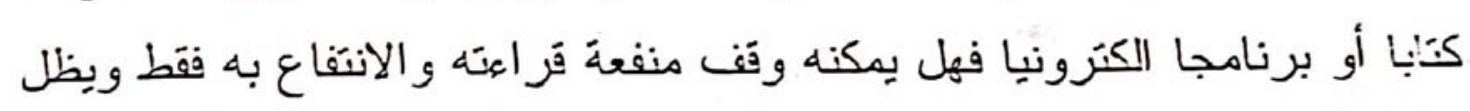
متكا لأصل المال، و هل يمكن لطبيب أن يخصص يوما ثنابيَا من كل أسبوع، أو

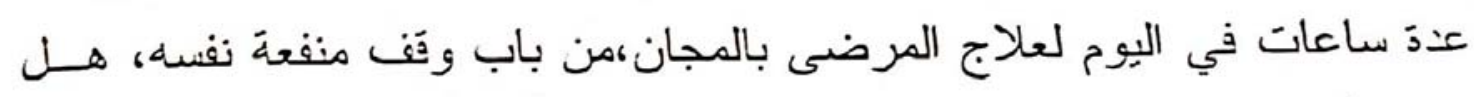

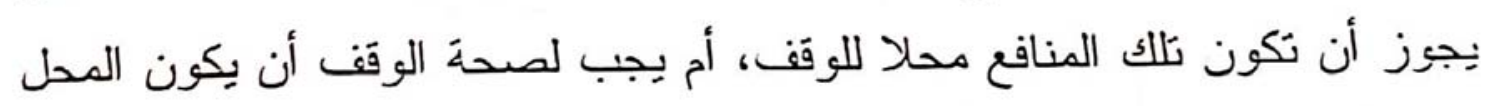
عينا

\section{تحرير الخلاف في المسألة:}

أو لا: لا يوجد خلاف بين العلماء في جواز التبر ع بالمنافع علــى ســبيل

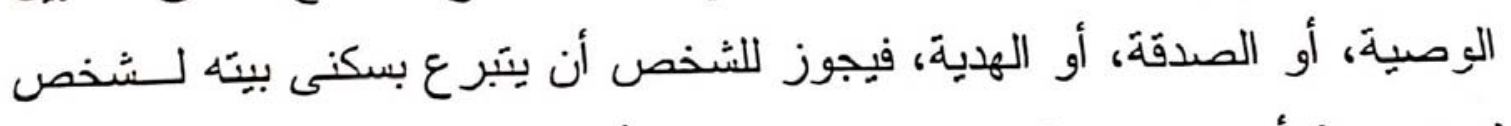

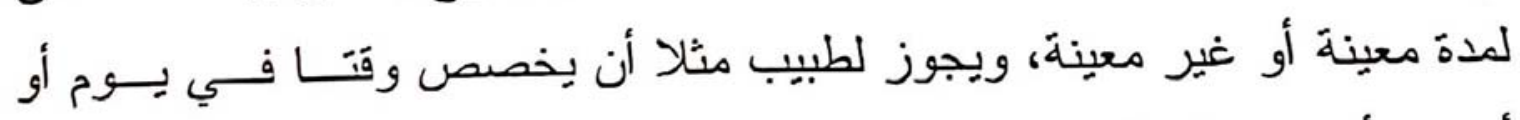

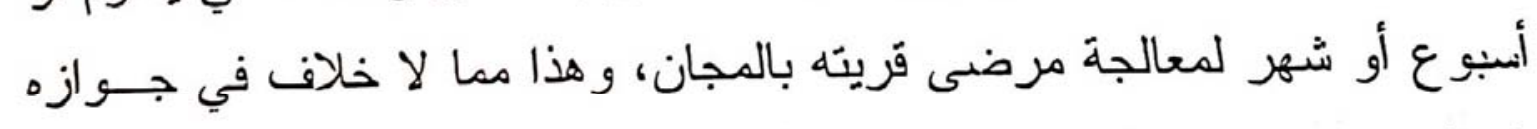
بل النصوص تدعو إلبه، إنما الخلاف في مدى كون هذا الصنيع من باب الوقف

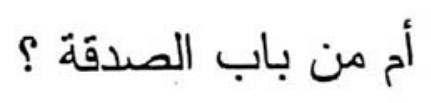

ثانيا: إن أصل الخلاف في هذه المسألة ونظير اتها هن الصور المسستحدثة في باب الوقف مبني على الاختِلف بين الفقهاء في مسألة مدى جواز الخــروج عما وردت به النصوص والآثار في باب الوقف أم يجب الوقوف عندها؟

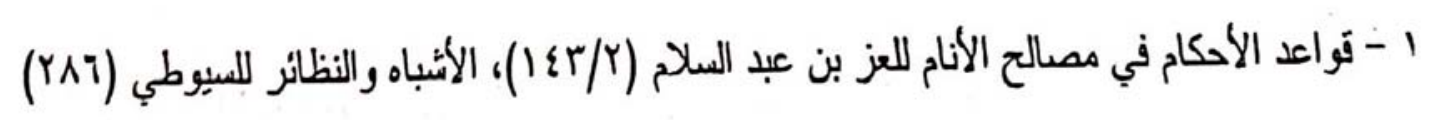


فالذين ألزموا بعدم جواز الخروج عما وردت به النصوص منعوا وقَّن

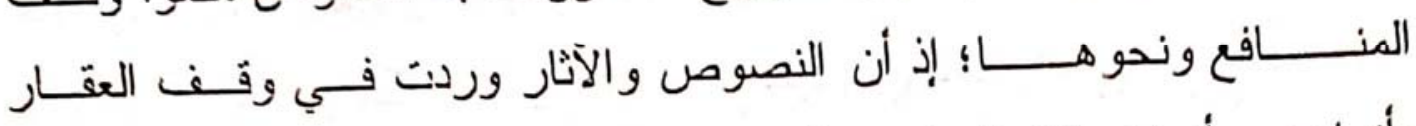

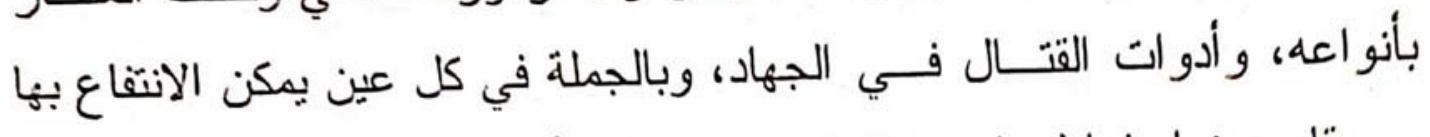
هع بقاء عينها، فما لم يكن كذلك لا يجوز وقفه، أما الذين نونسع ا ولم يققوا عند

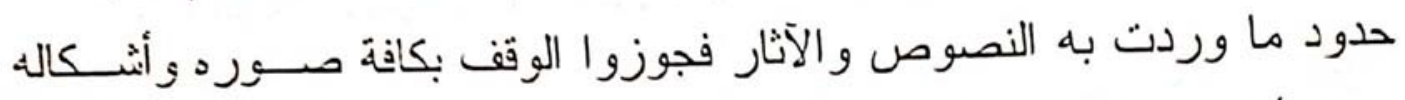
سواء أكان عبنا أم منفعة، مؤبدا أو غير مؤبد ما دام يحقق مقصد الوقة. قال ابن قدامة:"وجملة ذلك أن الذي يجوز وقفه: ما جــاز بيعـه، وجــاز

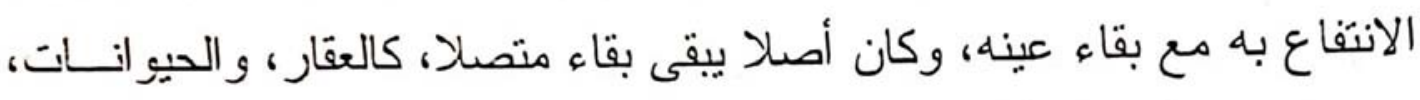

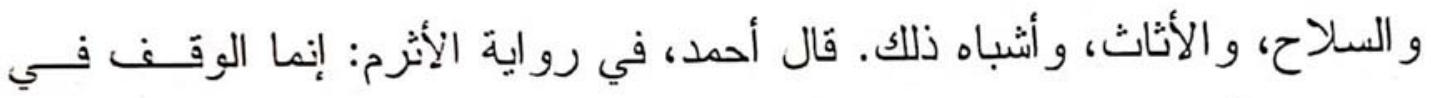
الدور و الأرضين، على ما وقف أصحاب رسول اله صلى اله عليه وسلم. وقَال في من وقف خمس نخلات على مسجد: لا بأس به. وهذا قَّل الثافعي، وقال أبر يوسف: لا يجوز وقف الحيوان، ولا الرقيق، ولا الكــراع، ولا العـروض، و لا

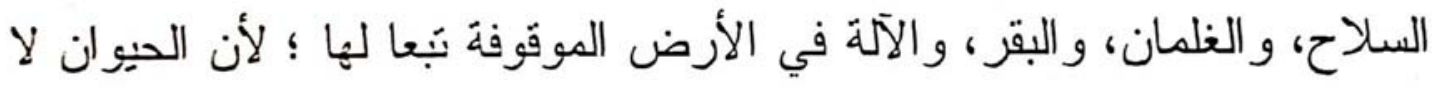
يقاتل عليه، فلم يجز وقفه، كما لو كان الوقف إلى مدة. وعن ماللك في الكــراع و السلاح روايتان. ولنا أن النبي صلى الله عليه وسلم فَال: (أما خالا فقد احتـبس

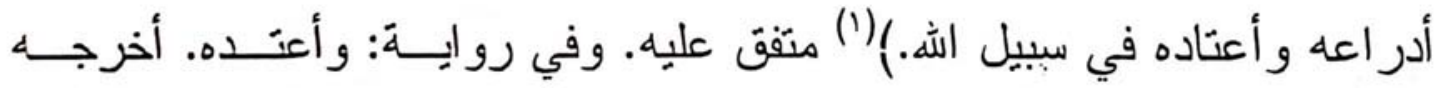

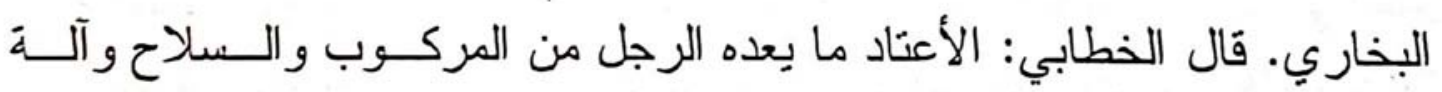

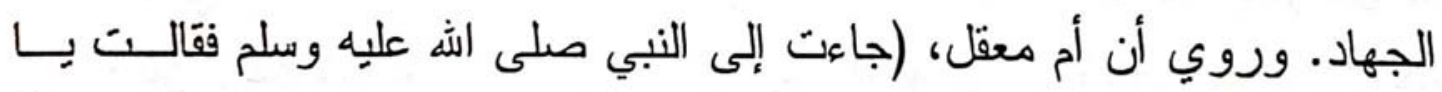
رسول اله، إن أبا معقل جعل ناضحه في سبيل اله، و إني أريد الحج، أفأركبــه ؟

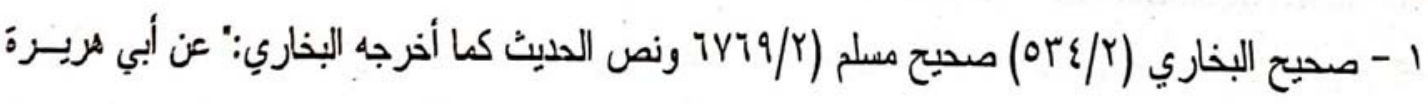

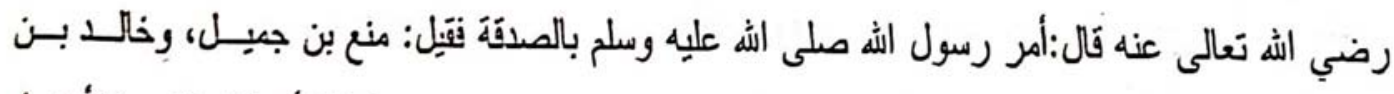
الوليد، وعباس بن عبد المطلب فقال النبي صلى الله عليه وسلم: ما ينقم بن جميل إلا أنه كان فتيــرا فأغنــاه

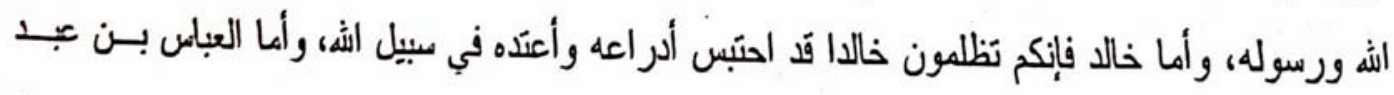

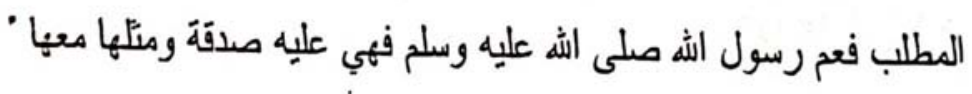


فقال رسول اله صلى اله عليه وسلم اركبيه، فإن الحــج والعمــرة مــن ســبيل اله)(') لأنه بِحصل فيه تحبيس الأصل وتسبيل المنفعة، فصح وقفه، كالعقــار

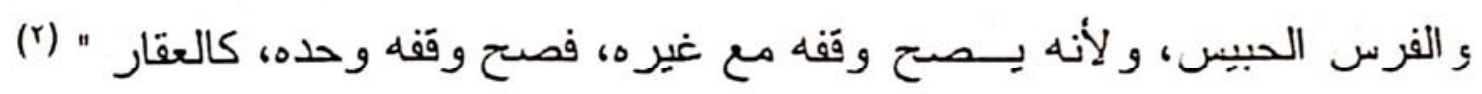
ويلاحظ من النص المتقدم لابن قدامة: أن ما يجوز وقفه والــذي وردت فيهه النصوص قَّ تحقق فيه أحد أمرين: أحدها: يحصل فيه تسبيل الأصل وتسبيل

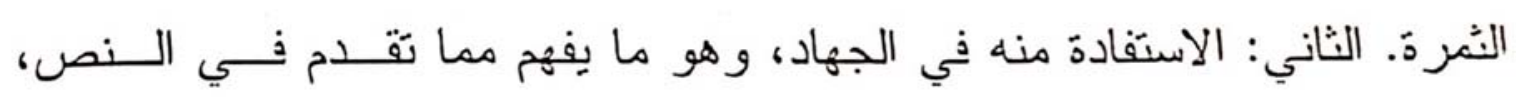
فَتجويز الإمام أحمد لوقف الدور والأرضين كما جاء في رواية الأثرم على مهـا

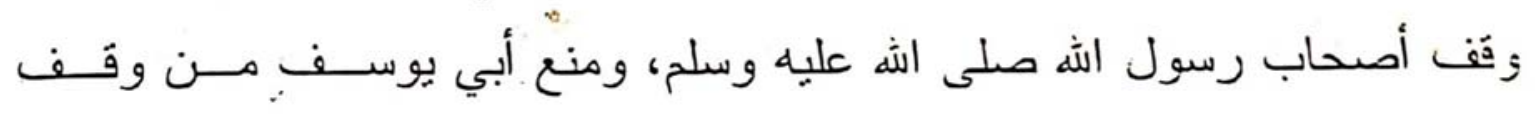

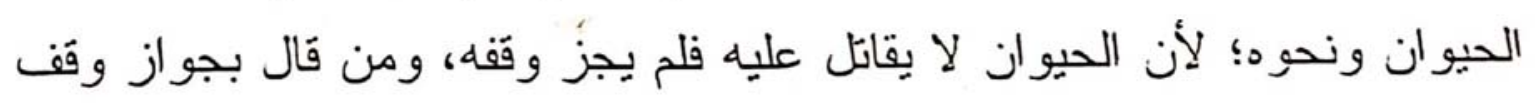
السلاح فلما صـح من خبر خالا. أما غير ذلك مما لا بِمكن الاستفادة منه في القتال، أولا يمكن حبس أصله فيه ولا تشبيل ثرنه فلا يجوز وتفه، ومن ذلك وقف المنافع.

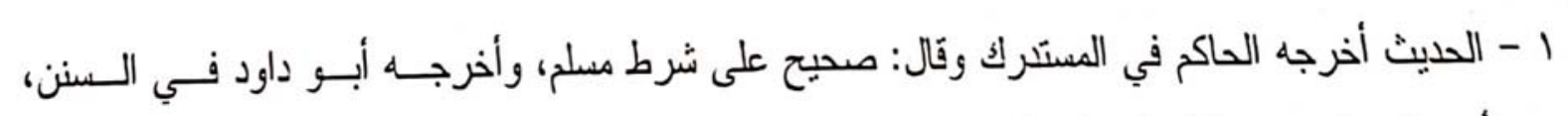

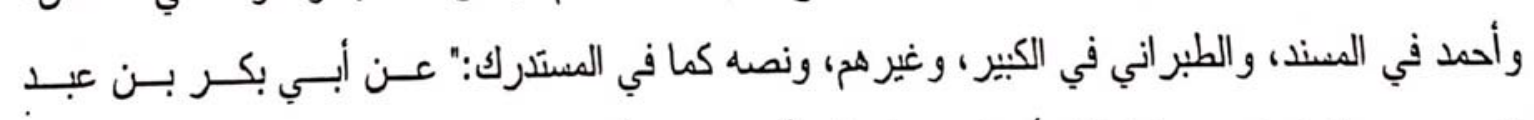

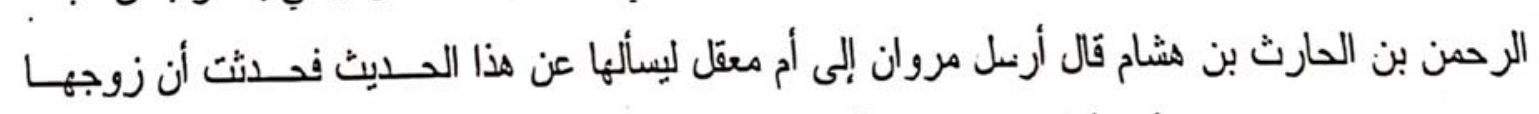

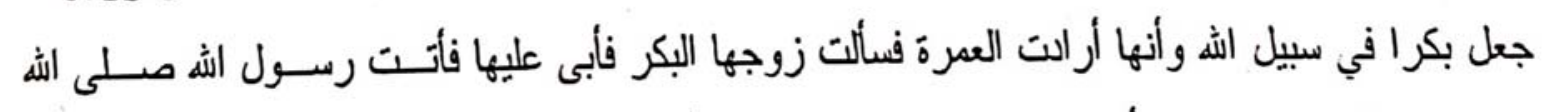

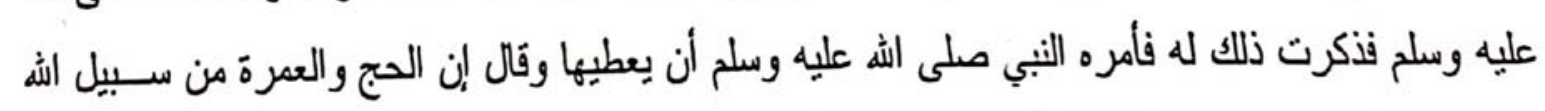

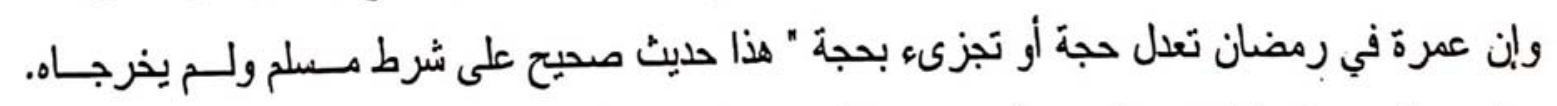

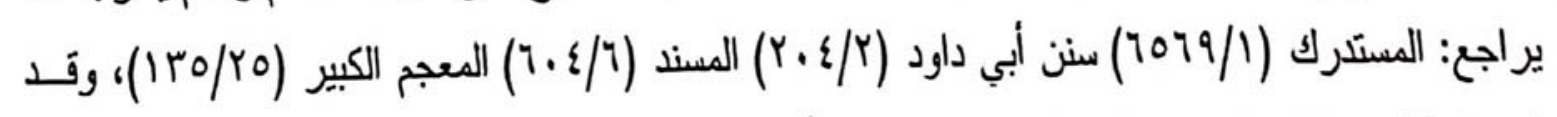

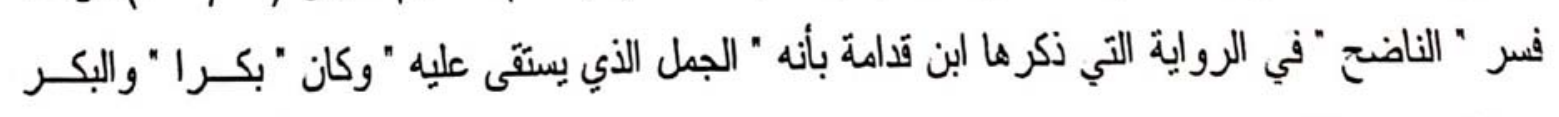
هو الفنى من الإبل.

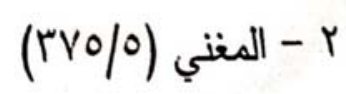




\section{ولما تقدم فقد اختلف الفقهاء في هذه المسألة على قولين:}

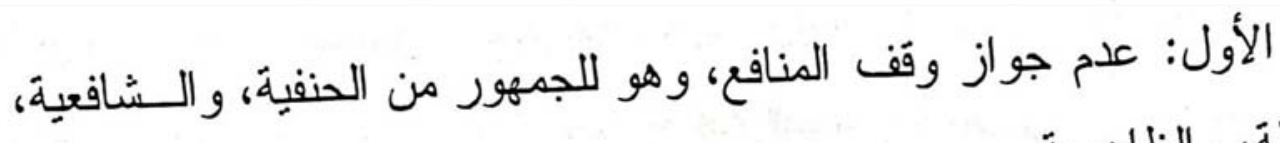
و الحنابلة، و الظاهرية.

فالحنفية لم يجيزوا الوقف إلا في المال المنقوم، وعندهم: المنافع ليسست

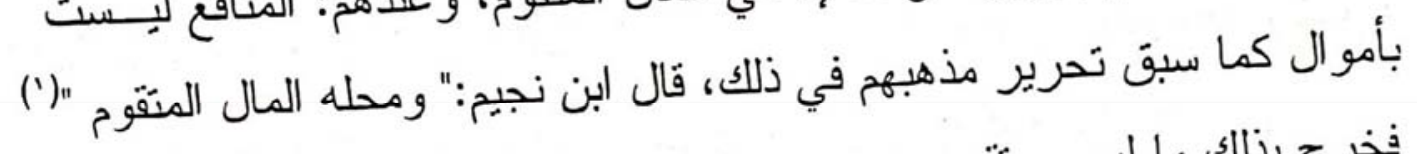
فخرج بذلك ما ليس بمثقوم.

وقال شيخ الإسلام زكريا الأنصاري فيما لا يجوز وقفه:" ولا وقف منفعة

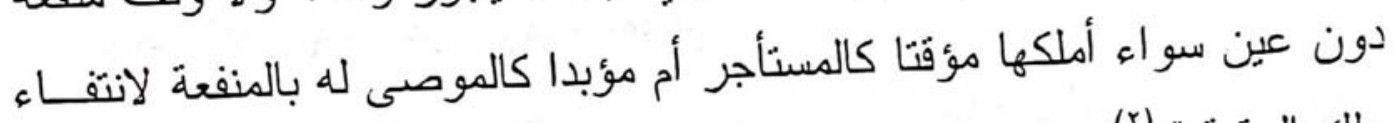

ملك الرقبة " (r)

وقال البهوني:" وكذا لا يصح وقف منفعة " (r)

وقال ابن حزم حاصر ا ما يجوز وقفه:" التحبيس - وهو الوقف - جـائز

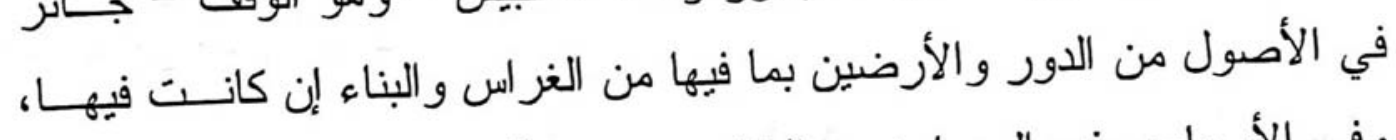

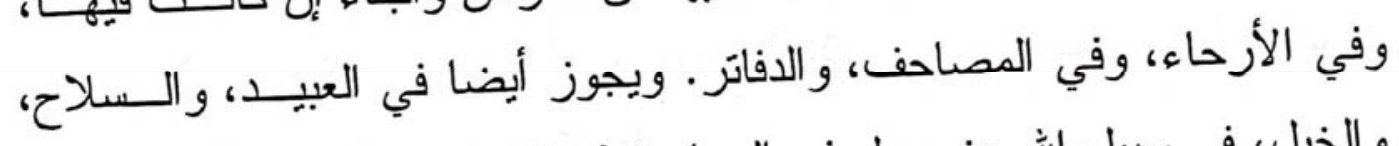

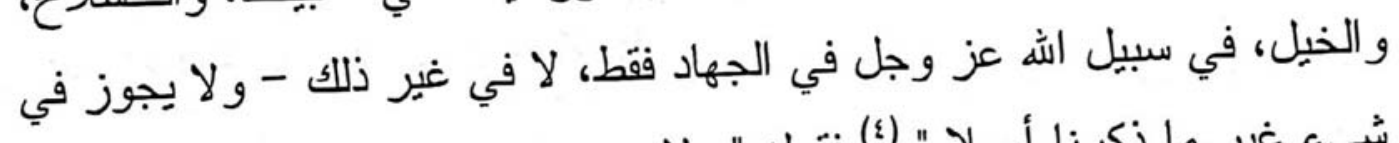

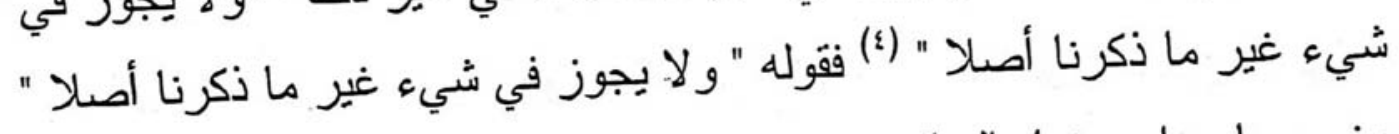
يخرج ما عداه ومنها: المنافع.

الثاني: جواز وقف المنافع، وهو قَول المالكية، ورجحه ابن تيمِية.

$$
\begin{aligned}
& 1 \text { - البحر الرائق (Y/O.Y) } \\
& \text { r - أسنى المطالب (r/Y } \\
& \text { r - شرح منتهى الإرادات (r/r) } \\
& \text { ؛ - المحلى (1 } 1 \text { ( }
\end{aligned}
$$


جاء في الشرح الكبير تعليقا على قَول خليل:" وصـح وقَف مملــوك وإن

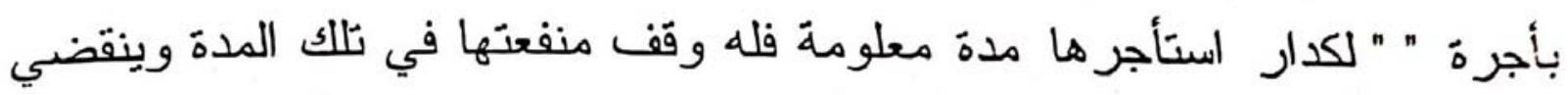

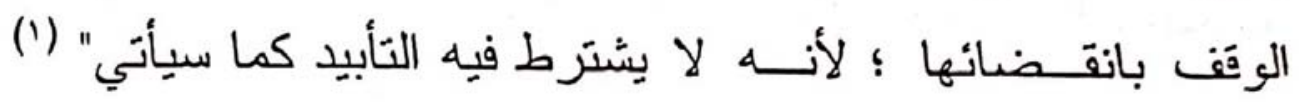

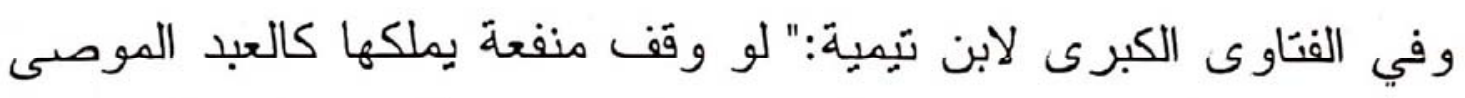

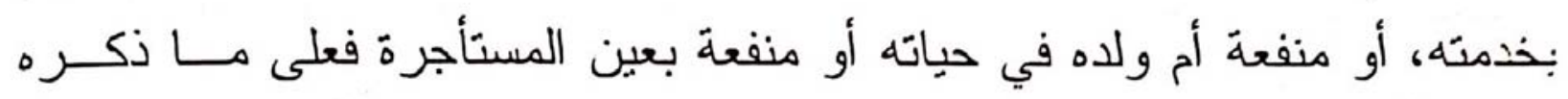

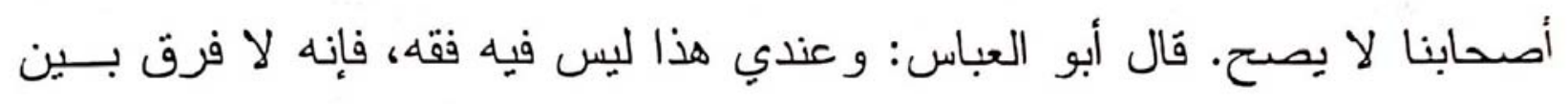

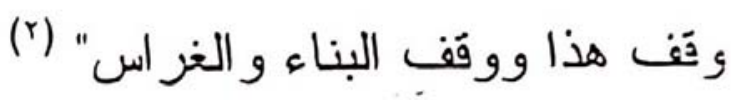

وجه القول بعدم جواز وقف المنافع:

أو لا: أن المنافع ليست بأموال متقومة، ومحل الوقف: المال المتقوم القابل

. لإِ قَف

ويناقَش هذا الوجه: بأن الر اجح أن المنافع أموال، وقَّ سبق تحرير هـــه

المنأللة في صدر البحث

ثانيا: أن الوقف يستّعي أصلا يحبس لتستوفى منفعتَه على مر الزمــان، ووةَف المنفعة بدون أصلها لا يحقق ذلك. للك.

قَال الأنصاري فيما لا يجوز وقفه:".. و لا وقف منفعة دون عـين ســواء

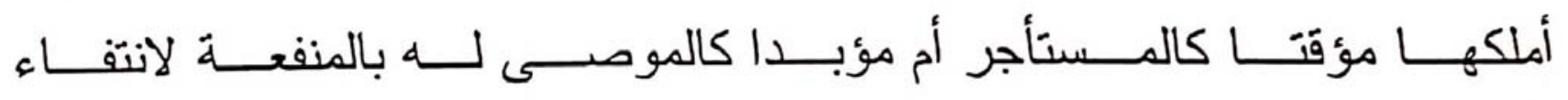

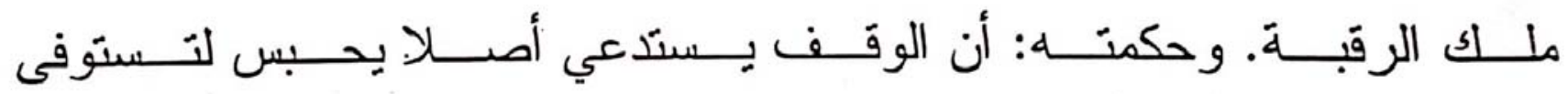

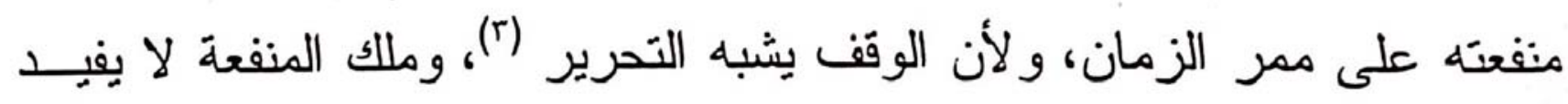

1 - (

$$
\text { r }
$$

r - المقصود بشّبه الوقن للتحرير : أنه يِّبه تحرير الرقاب، وكونه من أعــال القربـات، وخــروج الــالن الموقوف من ملكه إلى غير مالك. 
ولاية التحرير" (1) (2)

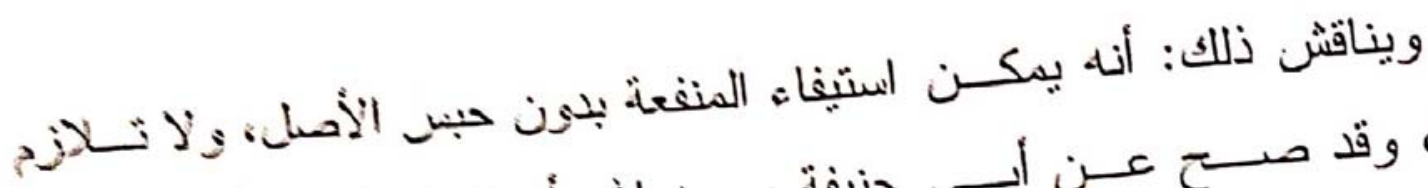

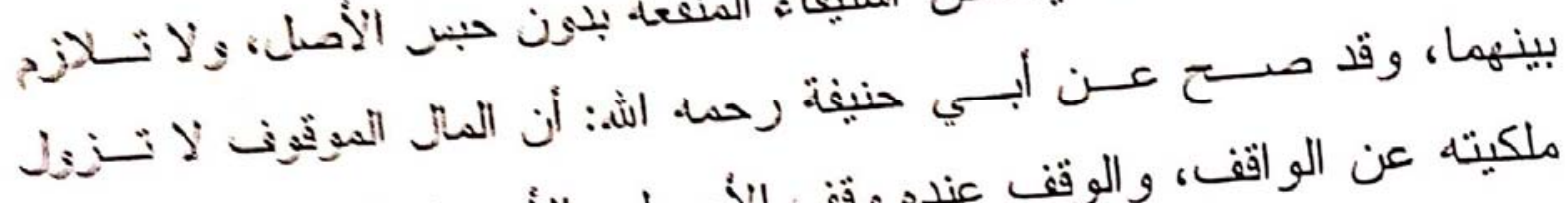

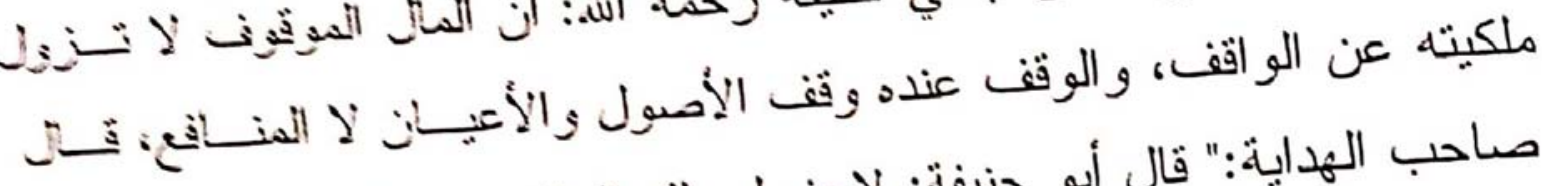

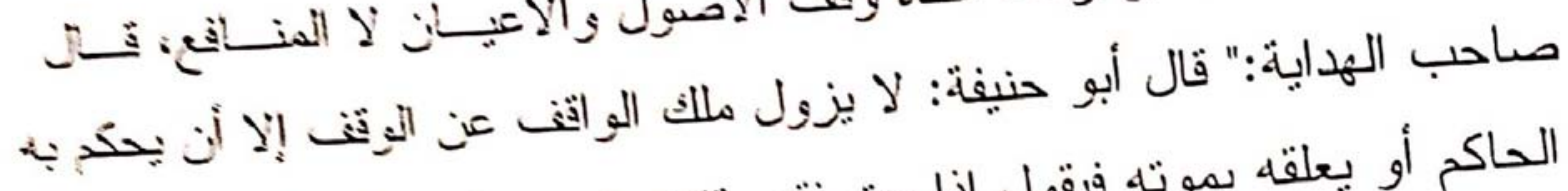

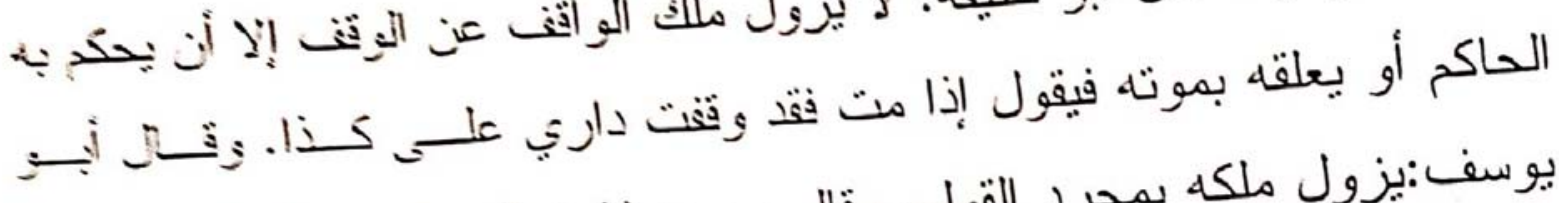

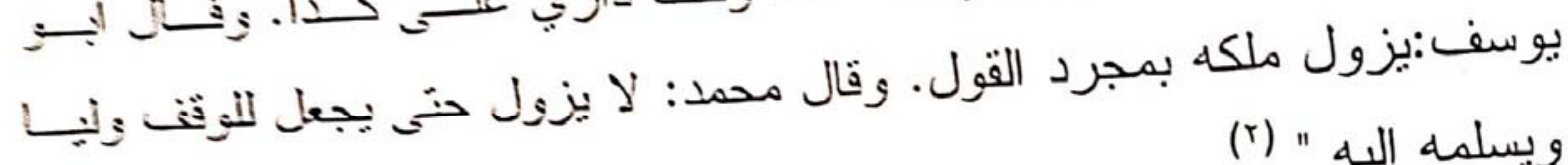
ويسلمه إليه " (r)

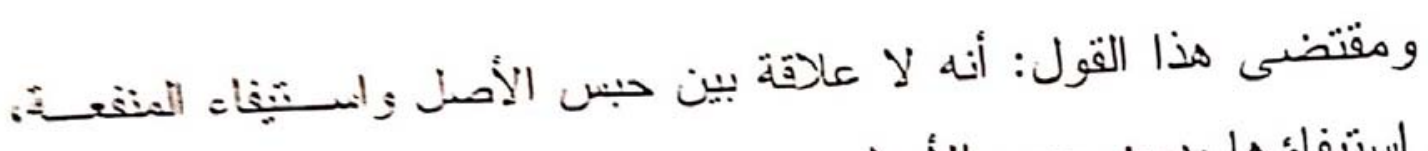
فيمكن استيفاؤها بدون حبس الأصل.

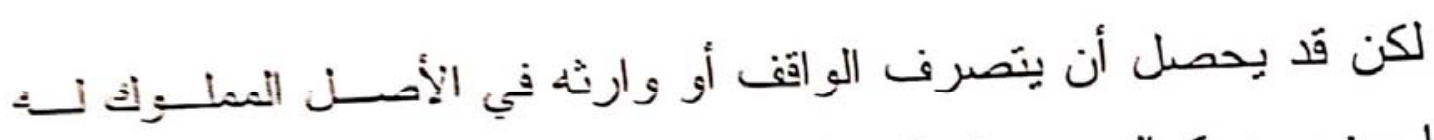

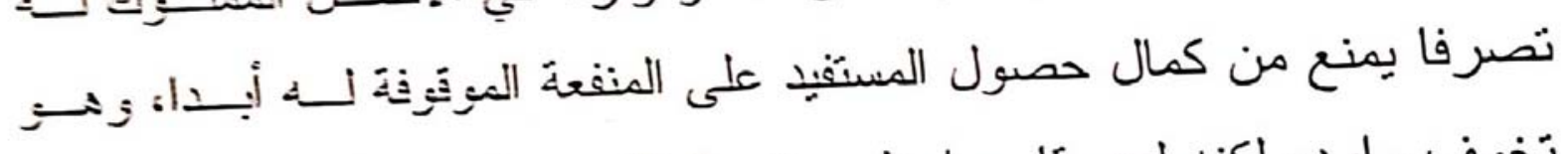

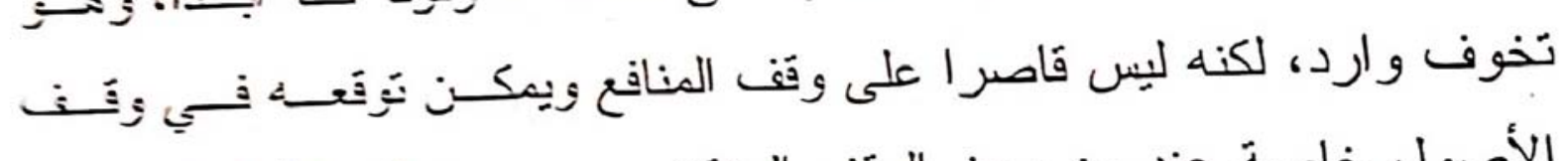

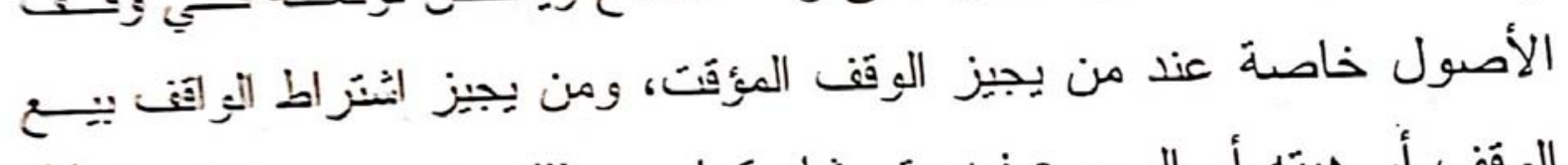

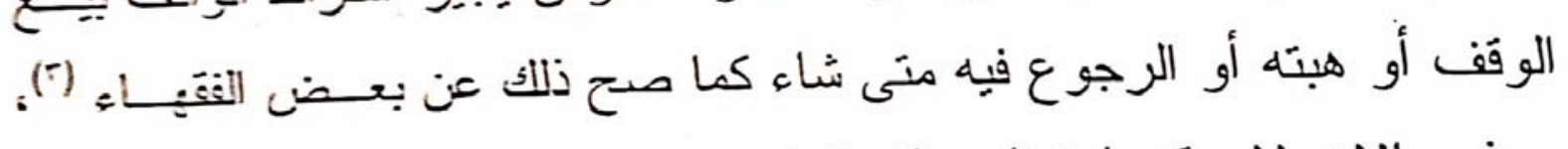
و هذه حالات لا يمكن استيفاء منافع الرقَف فيهيا بشكل دائم.

ثالثا: أن الرقبة أصل، و المنفعة فرع، ويجب أن ينبع الفرع الأصــل زع يِفصل عنه.

$$
\begin{aligned}
& 1 \text { - (أسنى المطالب ( } 1 \text { ( } \\
& \text { r - العناية شُرح الهداية (T/. r. }
\end{aligned}
$$

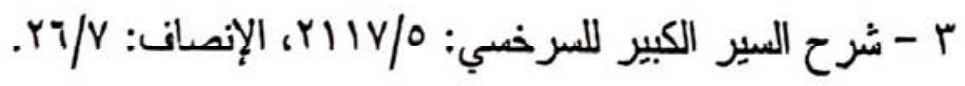


قال الشربيني الخطيب:" ولا يصح وقف المنفعة دون الرقبة مؤقَتَة كانت ـ

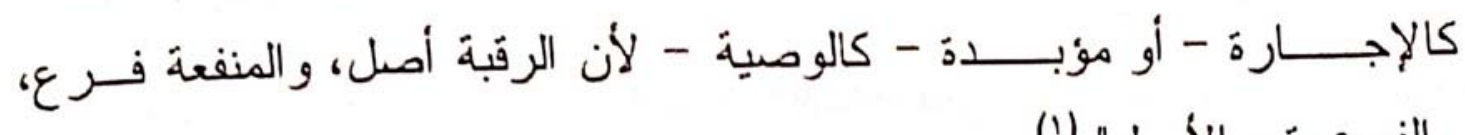
و الفر ع ينبَع الأصل". (1)

ومقتضى ذلك: أنه إذا كنْ الفرع موقوفا بلزم أن يكون الأصل كــللك،

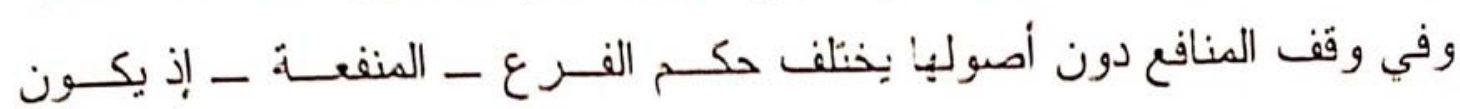
محبوسا، و الأصل غير محبونز.

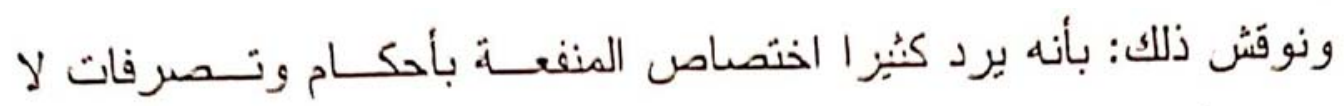

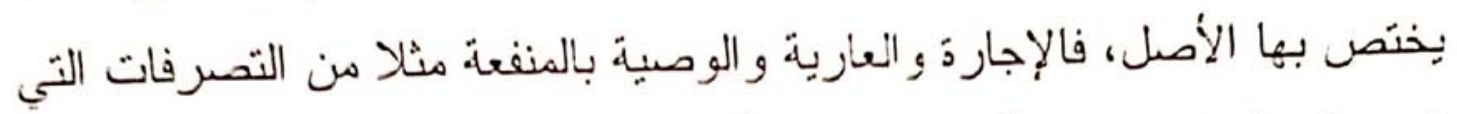

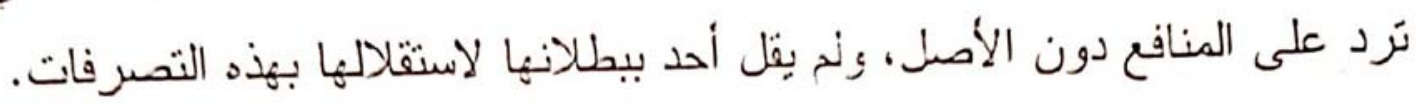

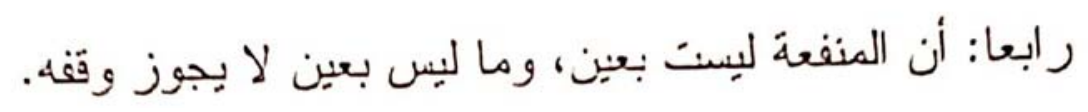

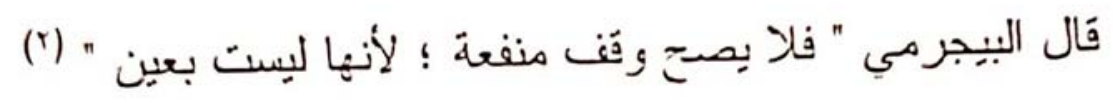

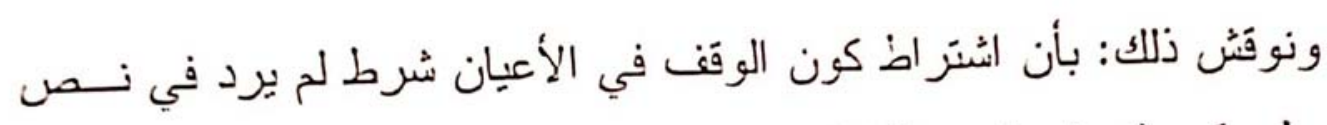

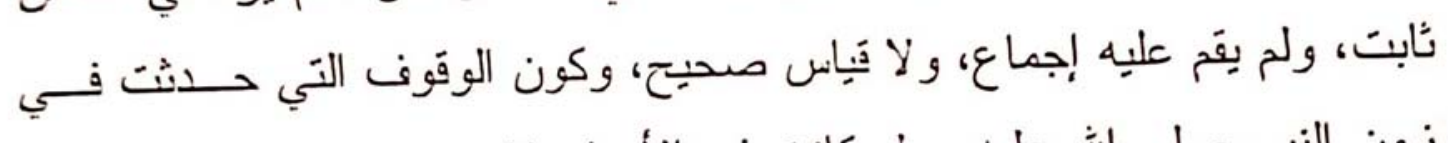

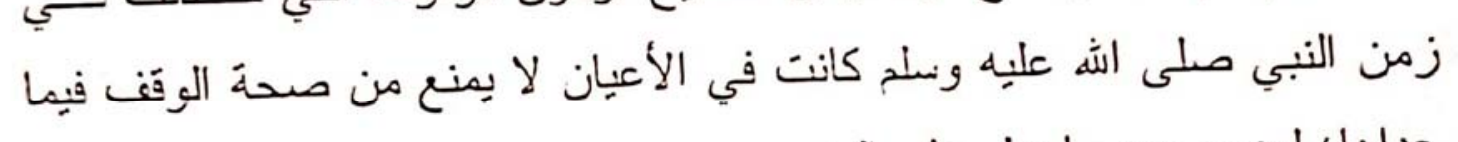

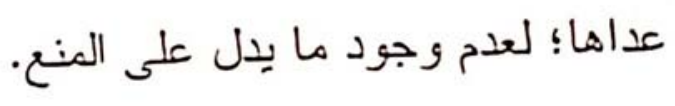

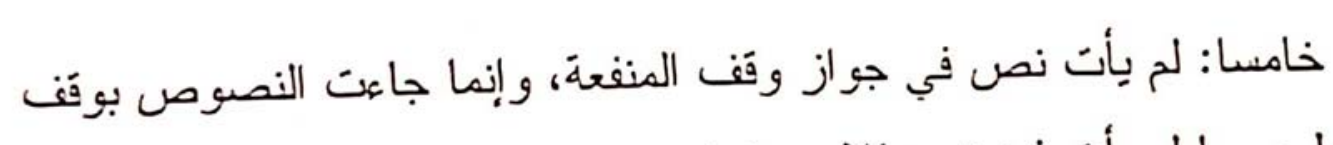
الأصول، وما لم يأت فيه نص فيلا بيجوز نحبيسه.

و هذا الوجه هو أظهر ما يِنَل به في هذه المسألة ونظير اتها؛ إذ الـوارد

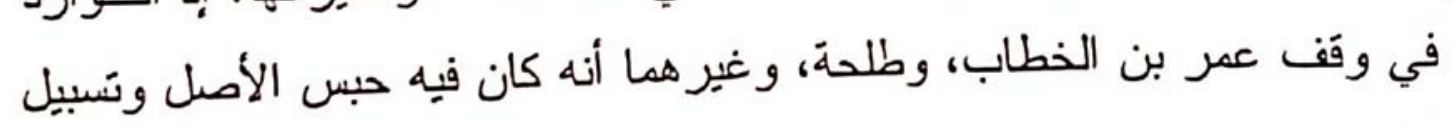

1 - مغني المتاج:

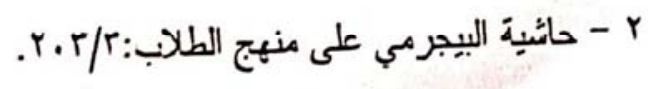


البثرة، فاعتبر الكثيرون من الفقهاء أن الوقف إن لم يكن على هذه الــصفة فــلا يجوز

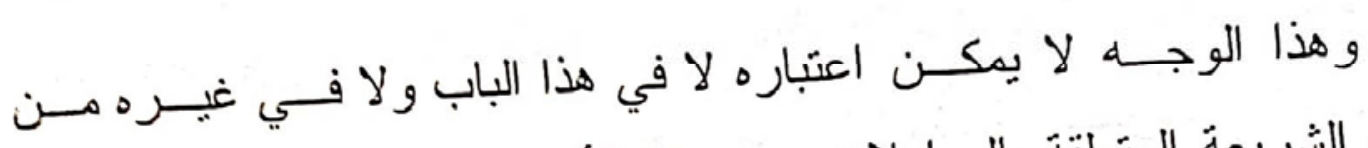

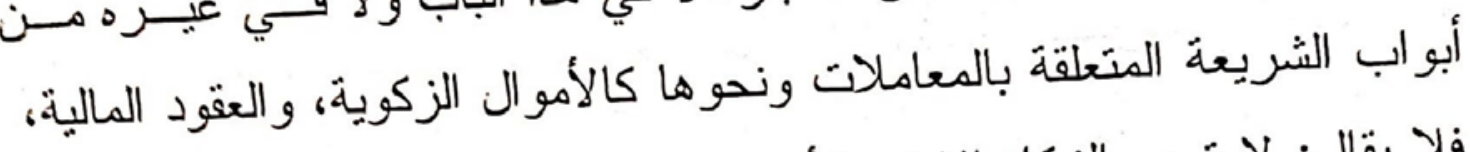

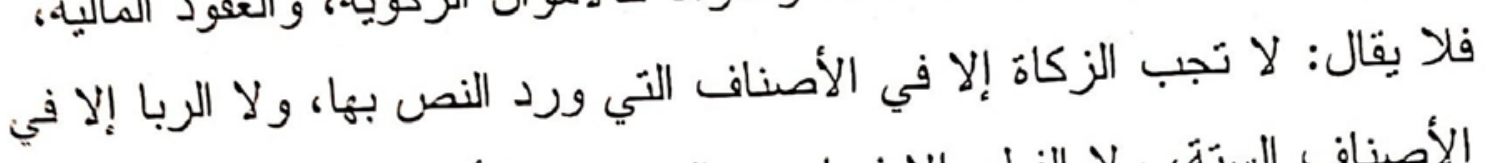

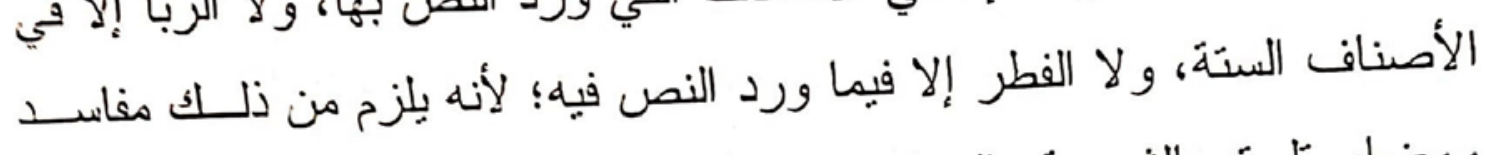

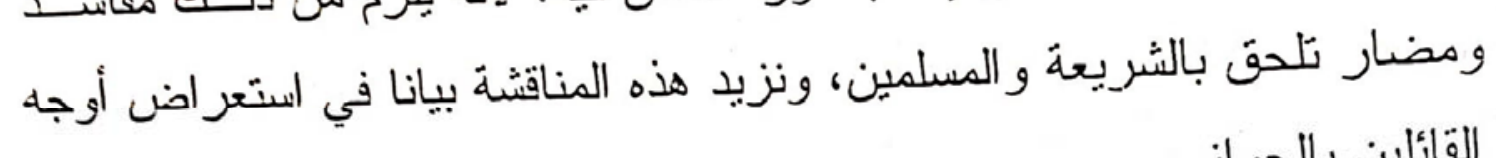

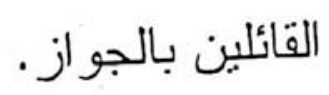

\section{وجه القول بجواز وقف المنافع:}

أو لا: القياس على جواز بيع المنافع المملوكة المباحة، وإجارتها، والوصية

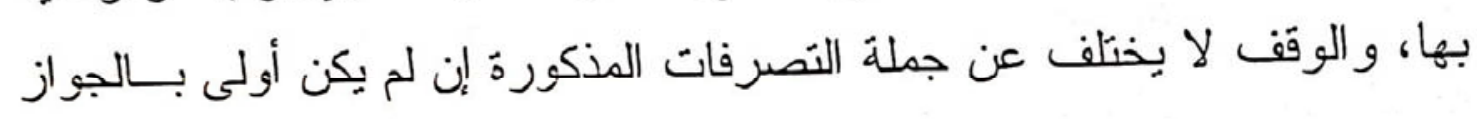
من

فعند الشافعية و الحنابلة: أجازوا ورود عقد البيع على المنافع تأبيدا، وهــو عقد معاوضةة، و المعاوضات مبنية على المشاحة و المنافسة.

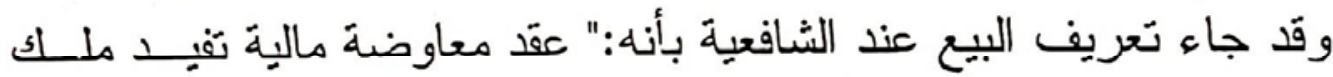

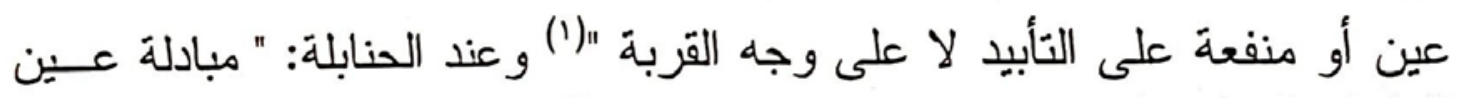

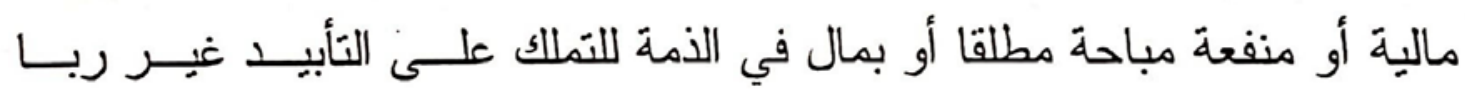
وقرض"(Y) ومثلوا للمنفحة ببيع نحو حق الممر.

$$
\begin{aligned}
& 1 \text { - مغني المحتاج (Y/r.r) } \\
& \text { r - شرح منتهى الإرادات (r/ }
\end{aligned}
$$


و أجاز الحنفية والشافعية والحنابلة الوصية بالمنافع مفردة، قال الكانساني:"

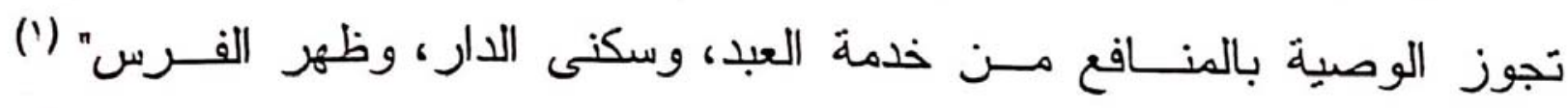

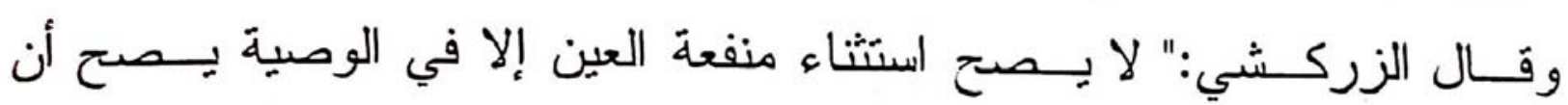

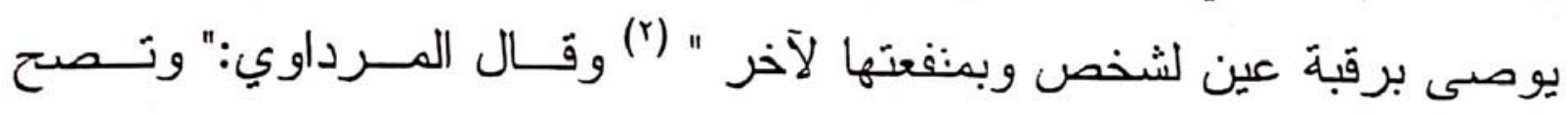

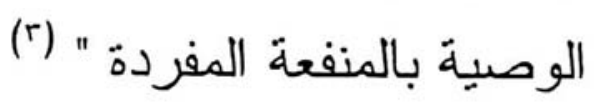

و عند الحنفية: أجازوا اليَف المعلق على الموت واعتبروه لازما مؤبــدأ

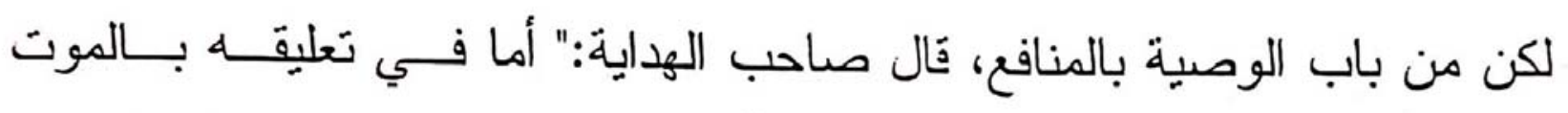

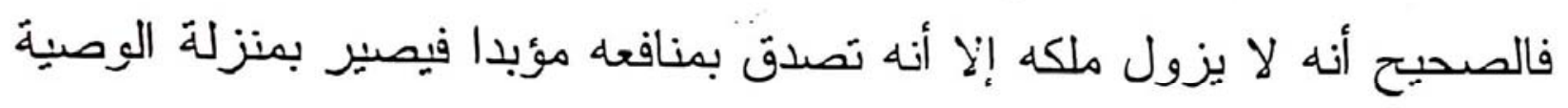

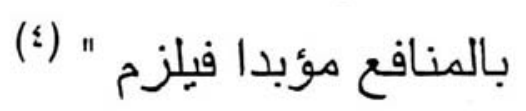

وعرَف الحنفية ما اصطلحوا عليه ب" وقف الضرورة " وصورتَه كما قَال الكمال:" يشبت الوقف بالضروزة، وصورته: أن يوصي بغلة هذه الدار للمساكين

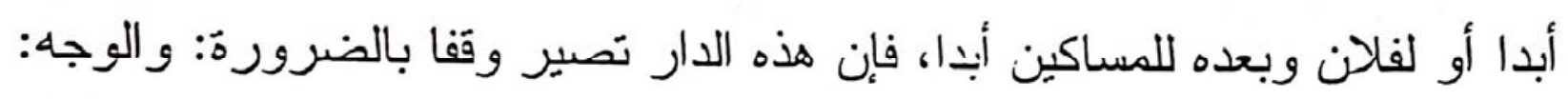

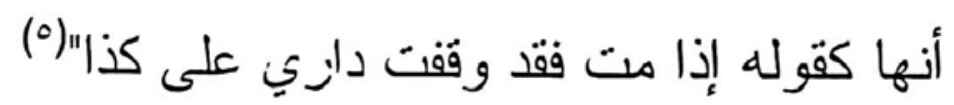

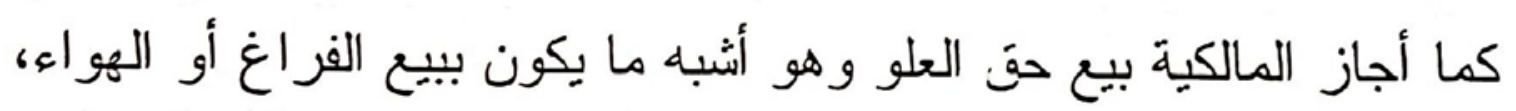

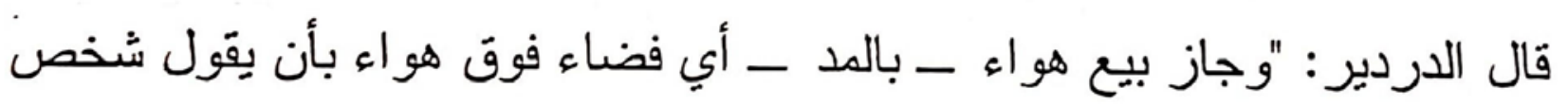

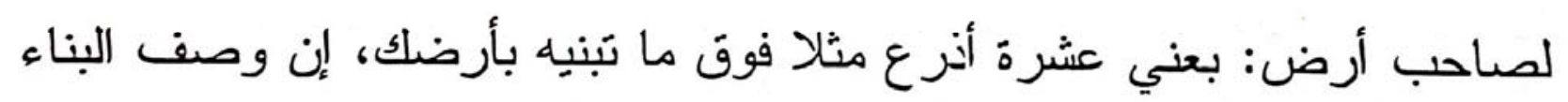

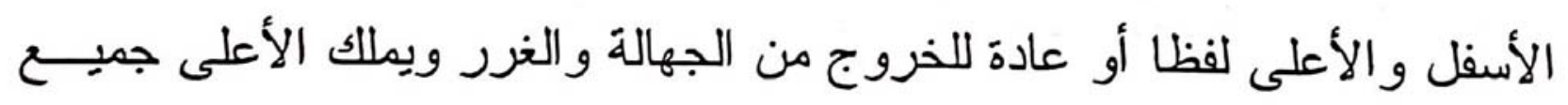

1 - (ror/V) - بدائع الصنائع

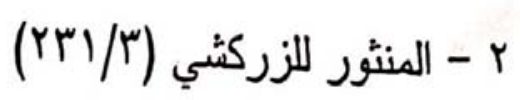

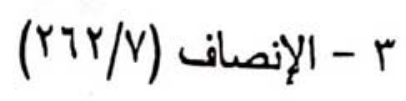

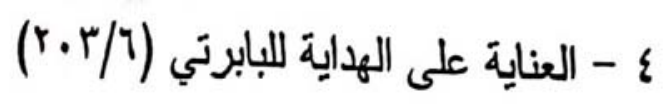

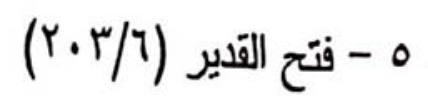


الهو اء الذي فوت بناء الأسفل ولكن ليس له أن يبني ما دخل عليـــه إلا برضــا (')" الأنسفل

ففي جميِع ما نَّدم عن لـد كافة المذاهب والاتجاهات وجدنا المنفعة مدــلا معنَبرا الإير اد العقود عليها سواء ماكان منها بعوض أو بغير عوض، و إذا صـح

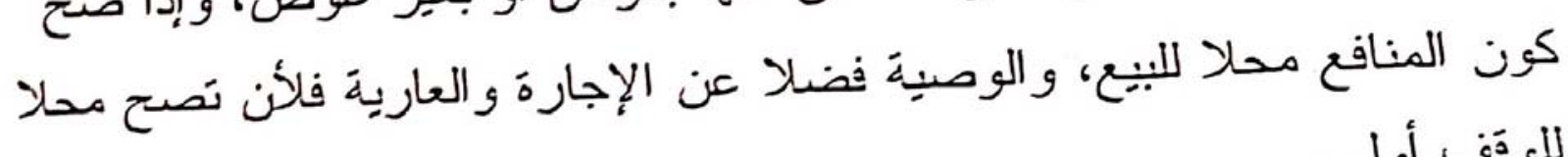

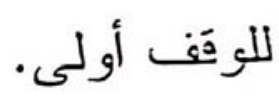

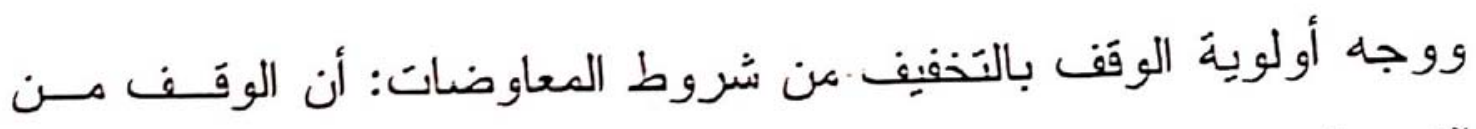

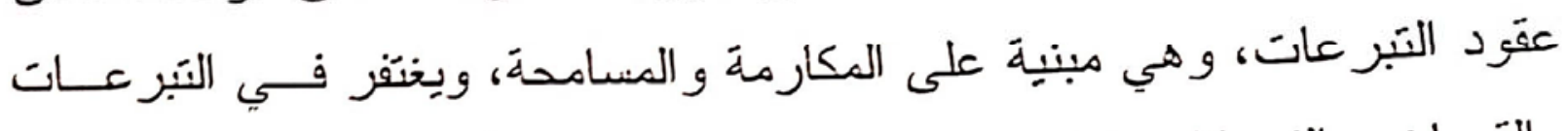

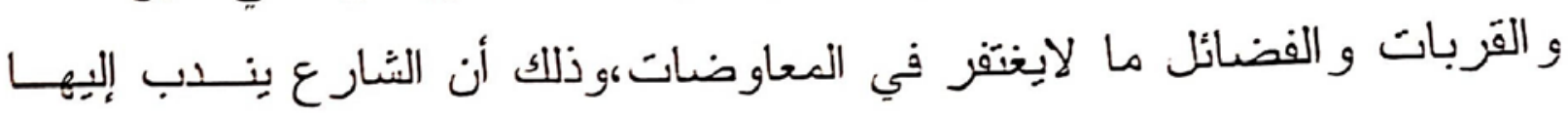

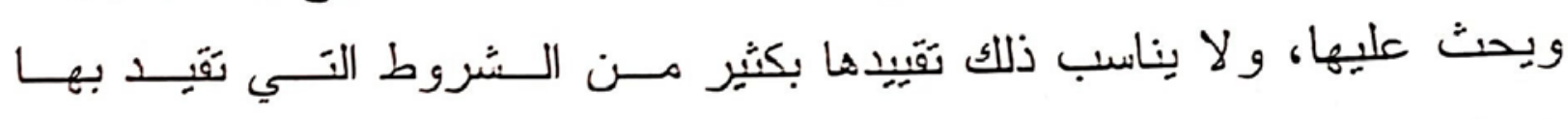
المعاوضات و التي تُونف في كثير منها إلى منع النزاع، ودفع الضرر، و التحوط

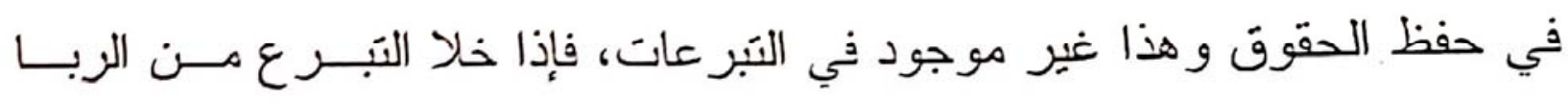
و الميسر و الغنش و المكاسب المحرمة ولكن في شيء منه جهالة أو غرر أو كــان غير موجود ونحو ذلك من الشروط التي تَشنَرط في المعاوضات لمنع ما ذكــر من مفاسد فلا بأس بصحة التبر ع وهو ما ذهب إلبيه كثير من العلمــاء، ويمكــن الإشارة إلى ذلك بما نص عليه الفقهاء في مسائل أفَـوى مــن وفَـف المنــافع وصححها العلماء بناء على القاعد المعتبرة " يخنَفر في التَبرعات ما لا بِختفر في المعاوضات: قال الرملي وابن حجر الهيثمي في مسألة وقف فحل للضراب، وهي على حسب أصول الوقف عند الشافحية لا تصنح لأنه لا تصح إجارته و عللـــوا ذلــك بقولهم " نعم يصح وقف فحل للضراب و إن لم تجز إجارته لأنه يختفر في القربة

1 - حاشية الدسوقي على الشرح الكبير (ب/ع ا) 
ما لا بغنتفر في المعاوضة " (') وقال الشربيني الخطيب في حديثه عن الوصية "

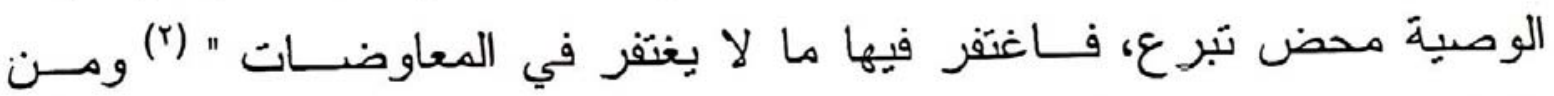

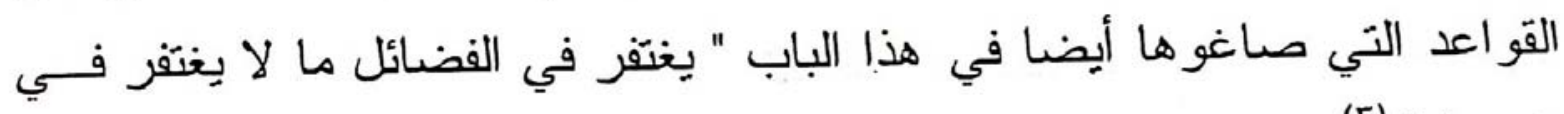
(r) " غيز ها (العو

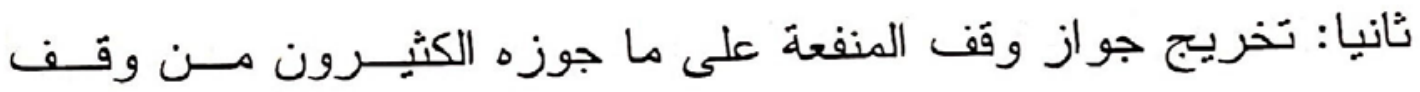
الغلات كالبناء و الغراس دون الأصول، وهي وجه من وجوه المنافع. جاء في الدر المختار " بنى على أرض ثم وقف البناء قـصدا بــدونها أن الأرض مملوكة لا يصح وقيل صـح و عليه الفتوى، سئل قارئ الهدايـة (؛) عــن وَّف البناء و الغر اس بلا أرض ؟ فأجاب: الفتوى على صحته ذلك " (•) وقال ابن حجر الهيتمي في فتاويه: " المنقول المعتمد صنحة وقف البنــاء و الغر اس في الأرض المستأجرة أو المستعارة، سواء المملوكة و الموقوفـــة قبـلـلـ مضي مدة الإجارة و العارية وبعده " (T). وقال الخطيب:" ولو وقف بناء أو غرسا في أرض مسستأجرة لهمــا، أو مستحارة كذلك، أو موصى له بمنفعتها فالأصح جوازه سواء أكان الوقــف قبــلـل انقضاء المدة أم بعده كما صر ح به ابن الصلاح، أو بعد رجوع المعير؛ لأن كلا

$$
\begin{aligned}
& \text { 1 - تحفة المحتاج لابن حجر الهيثمي (T/Yrv)، نهاية المحتاج للرملي (1/.rr). } \\
& \text { r } \\
& \text { r - r (19r/r) }
\end{aligned}
$$

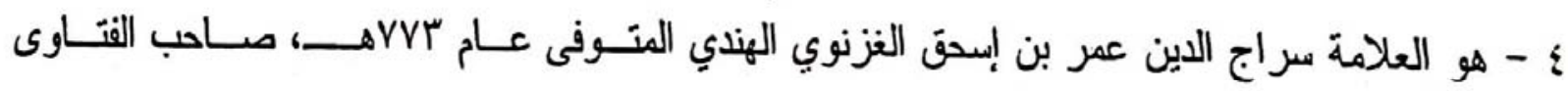

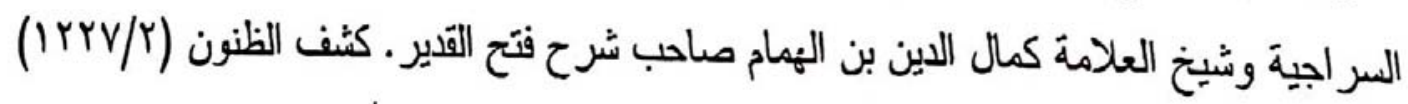

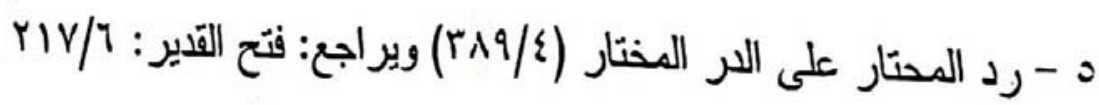
i - الفتاوى الفقهية الكبرى لابن حجر الهيثي ("//01) 


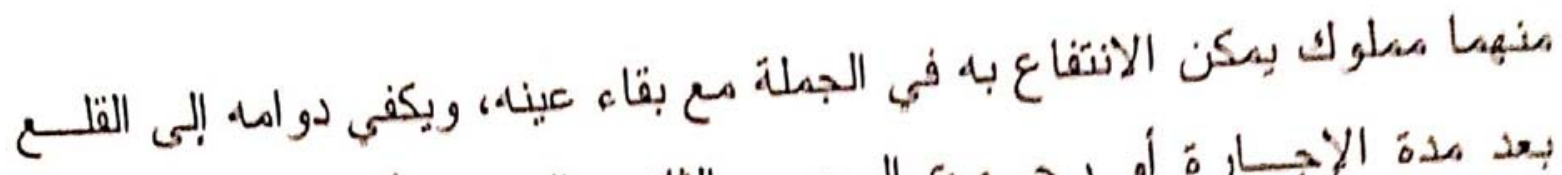

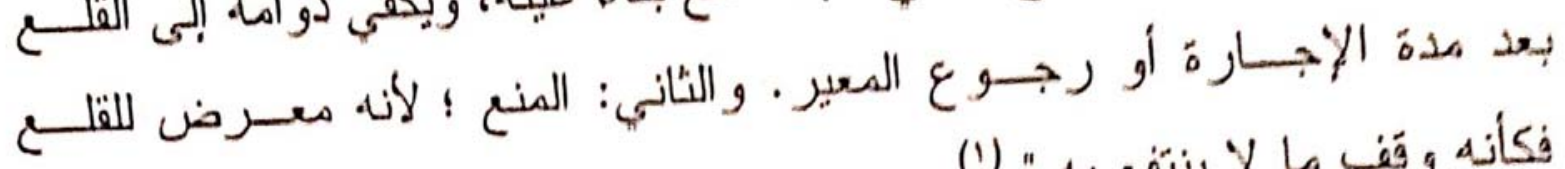

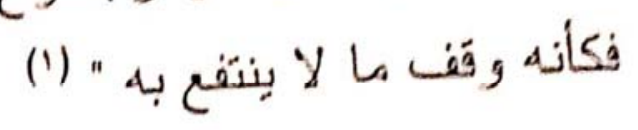

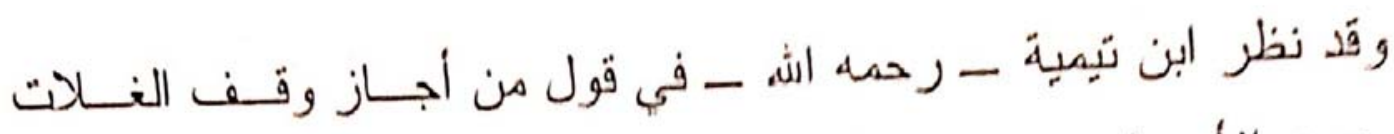

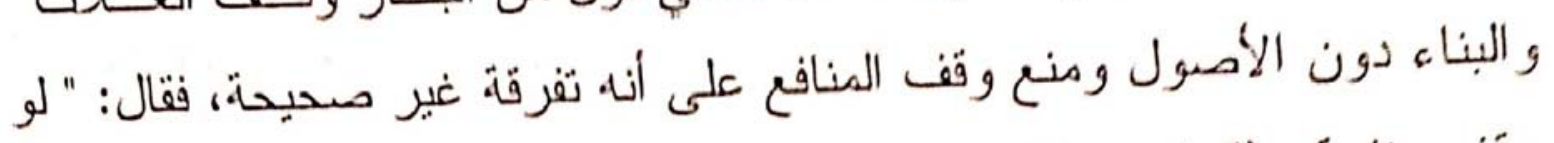

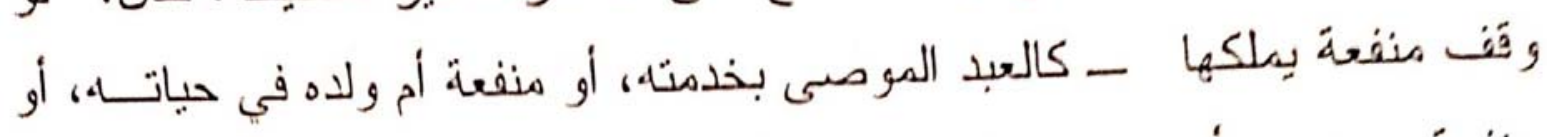

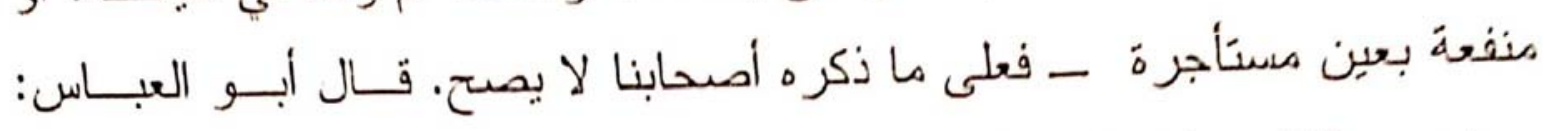
و عندي هذا ليس فيه فقه، فإنه لا فزق بين وقف هذا ووقف البناء و الغراس..."(r) ثالثًا: أن المنفعة مال يملك، وكل ما كان كذلك يجوز ودَّه، واعنبار المنافع

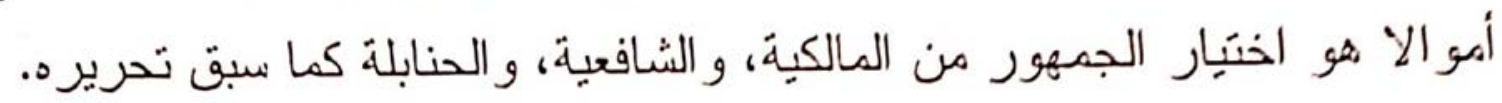
رابعا: ورود كثير من الأدلة تحث على التصدق بالمنافع، وهي كما تتـصرف

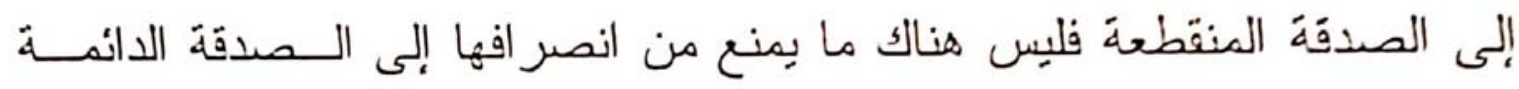
(الوقَت)، ومن ذلك:

أخرج الشيخان و اللفظ للبخاري من حديث أبي ذر - رضي اله عنه قال: سألت النبي -صلى اله عليه وسلم - أي العمل أفضل ؟ قال: إيمان

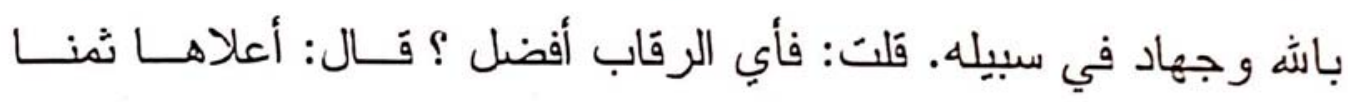

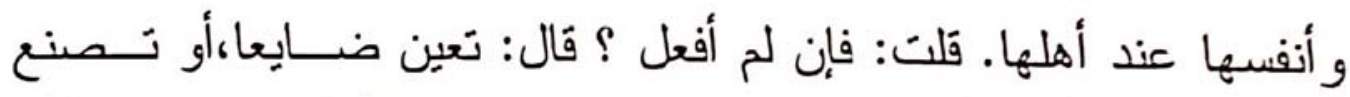

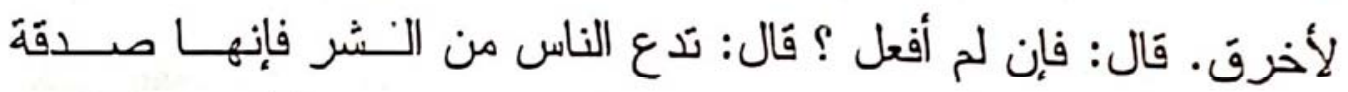
تصدق بها على نفسك "، و الأخرق: الذي لا صنعة له " (r)

$$
\begin{aligned}
& 1 \text { - مغني المحتاج (OTV/r) } \\
& \text { r - الفتاوى الكبرى (TYT/0) }
\end{aligned}
$$

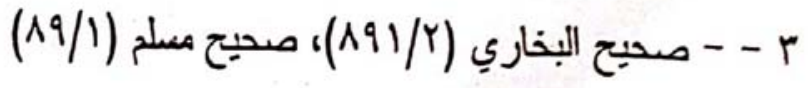


و عندهما عن أبي هربرة - رضي اله عنه - عن النبي - صسلى اله.

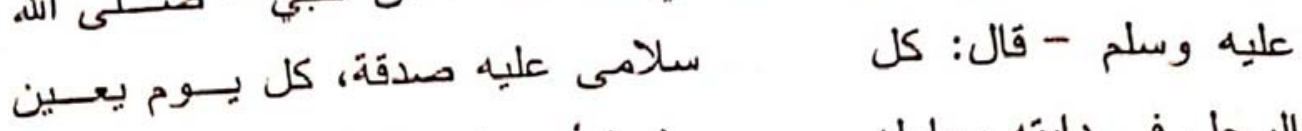

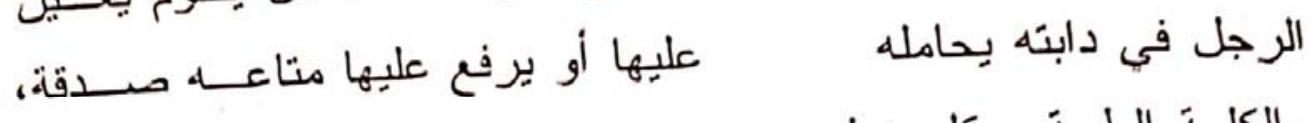

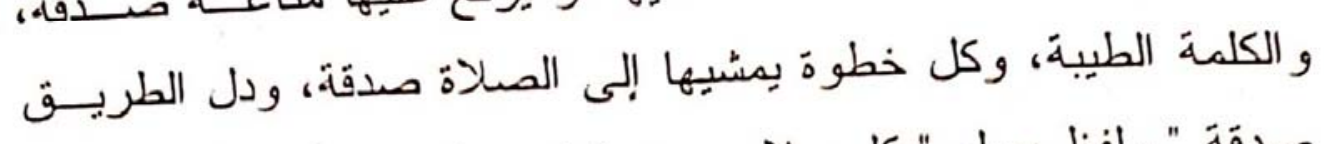

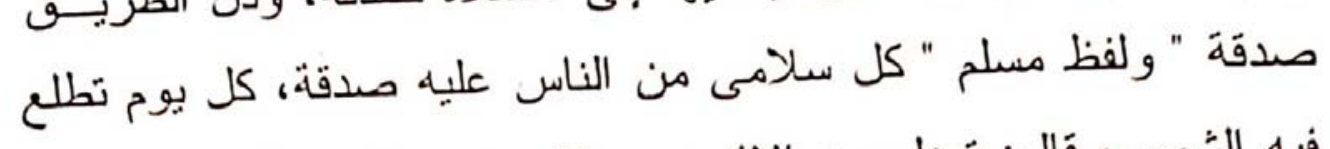

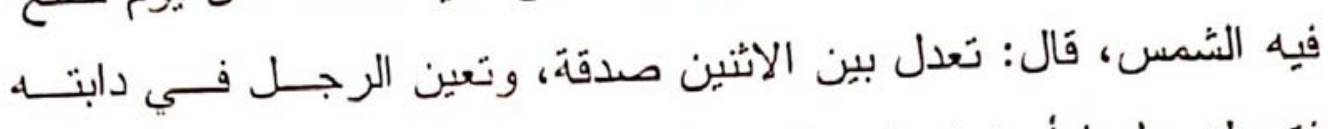

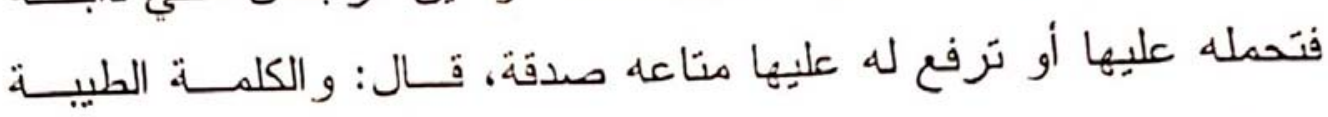

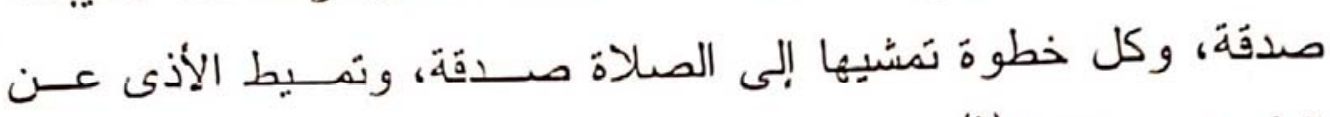

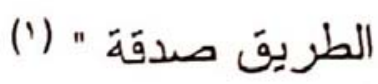

و عند النسائي في السنن الكبرى و أحمد في المسند قَال: فـــال النبــي -

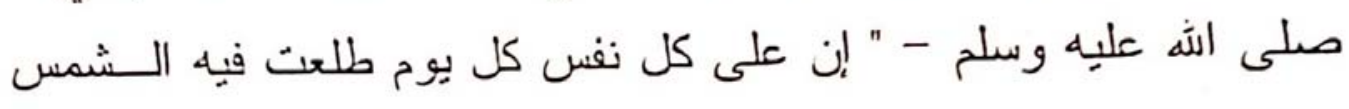

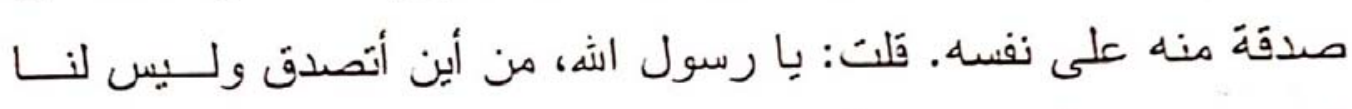

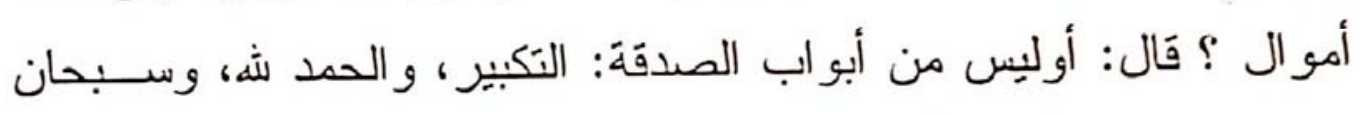
اله، وتنتخفر اله، وتأمر بالمعروف، وتنهى عن المنكر، وتعزل الشوكة عن طريق المسلمين، و العظم، و الحجر، وتَّي الأعمى، وتذل المستلكل على حاجةَ اللهَ قَد علمت مكانها، ونزفع بشدة ذر اعيك مع الضعيف، كل ذلك من أبواب الصدقةَ منك على نفسك...." و عند أحمد:".......وتهدي الأعمى، وتسمع الأصم، والأبكم حتى يفقها، وتدل المستذل على حاجةَ له قد علمت مكانها، وتَسعى بـشـدة ساقيك إلى اللهفان المستغيث، وترفع بشدة ذراعيك مع الضعيف كل ذلك من أبواب الصدقَة منك على نفسك..."(r)

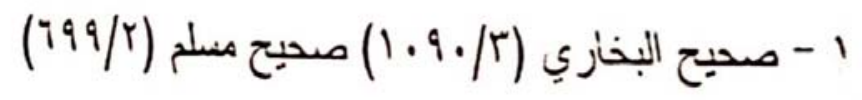
Y - المنن الكبرى للنسائي (ro/0)، المسند للإمام أحد (i ( i ) 


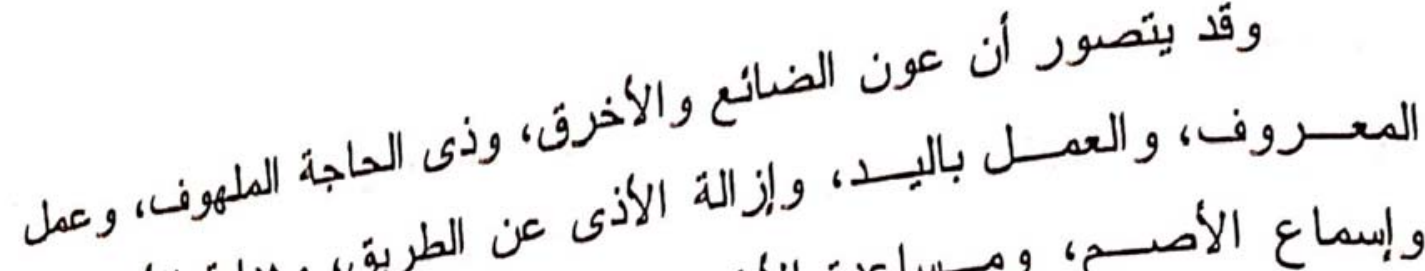

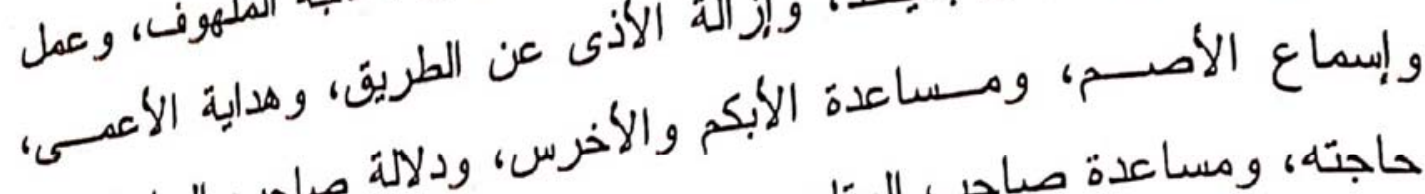

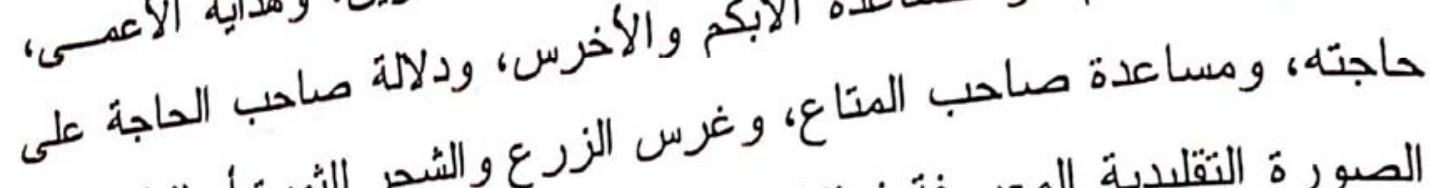

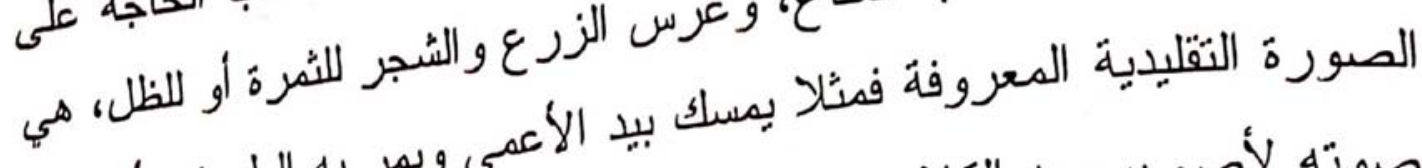

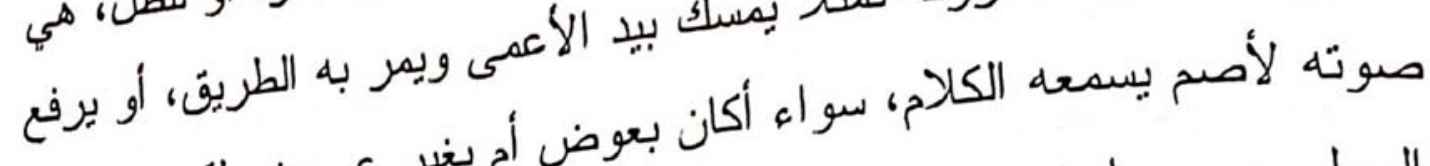

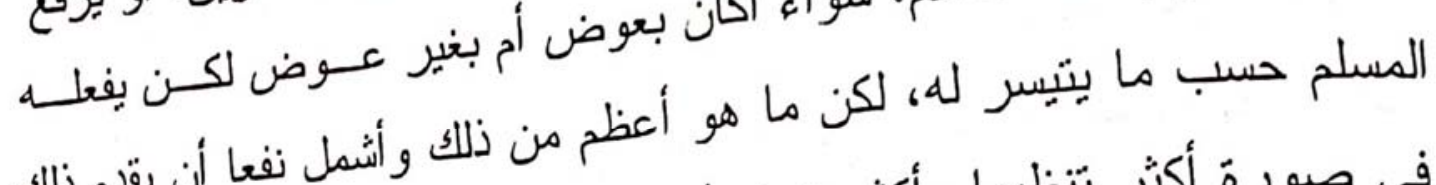

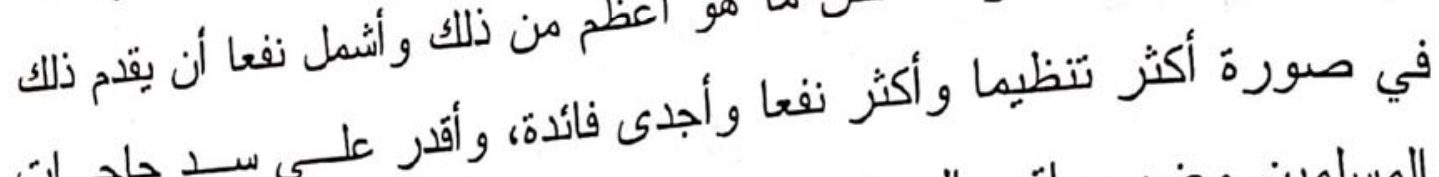

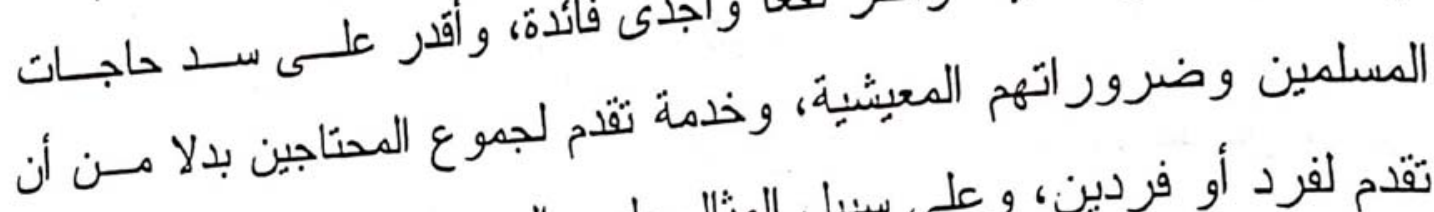

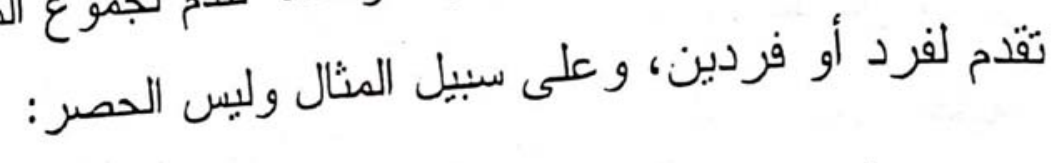

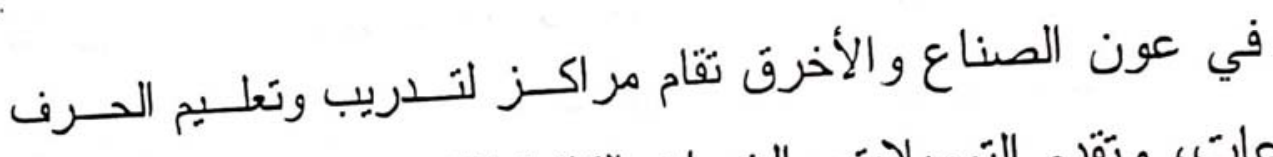

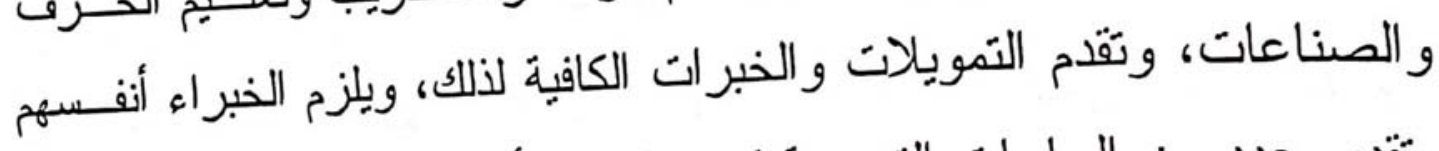

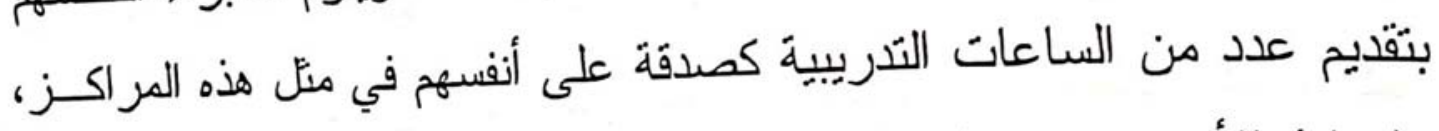

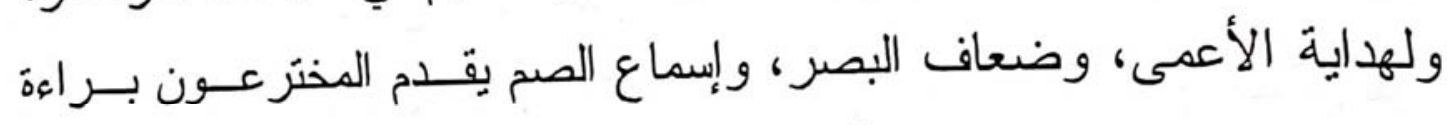

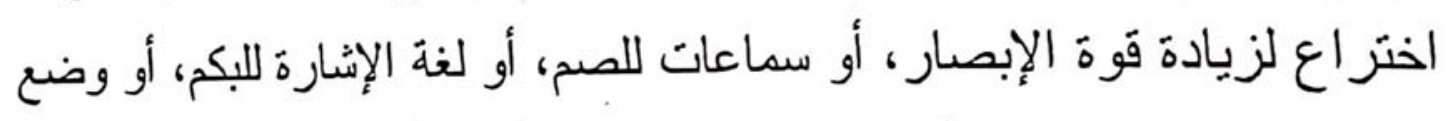

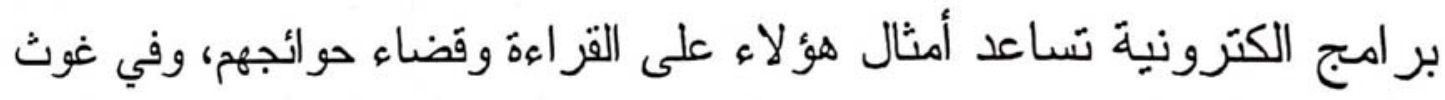

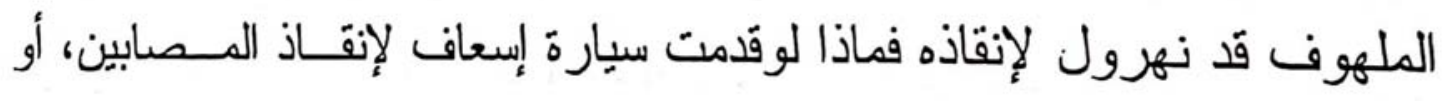
ساعدنا على نشر الثقافة الطبية المناسبة لإسعاف المصابين، والأمثلة كثيرة. خامسا: جزيان عادة الناس بالتعامل في المنافع بيعا وشراء، وتـــدقا،.

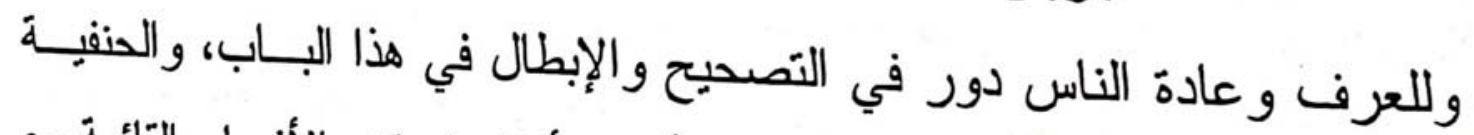

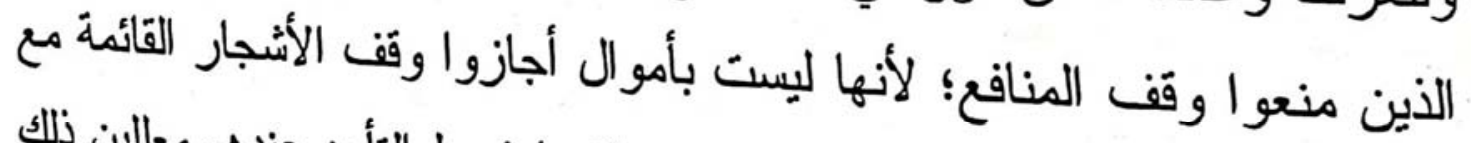

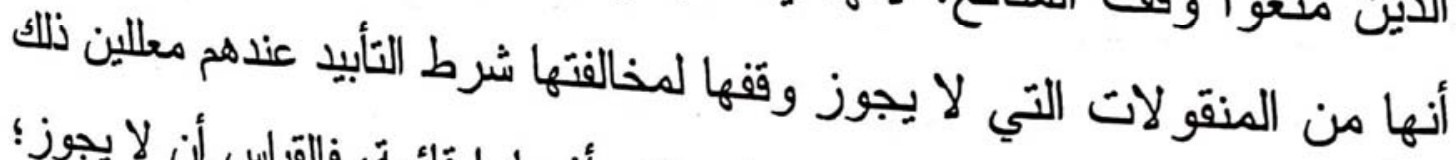

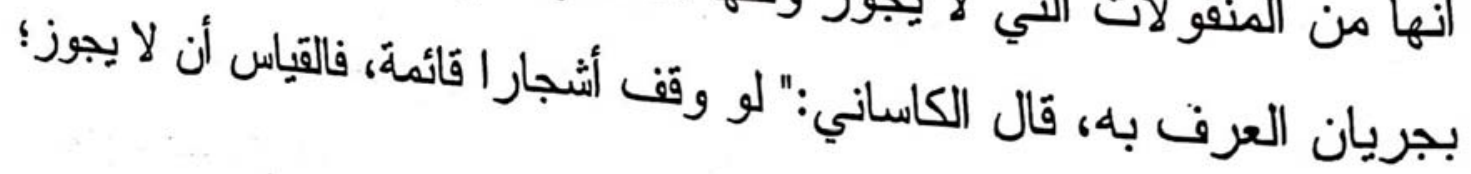




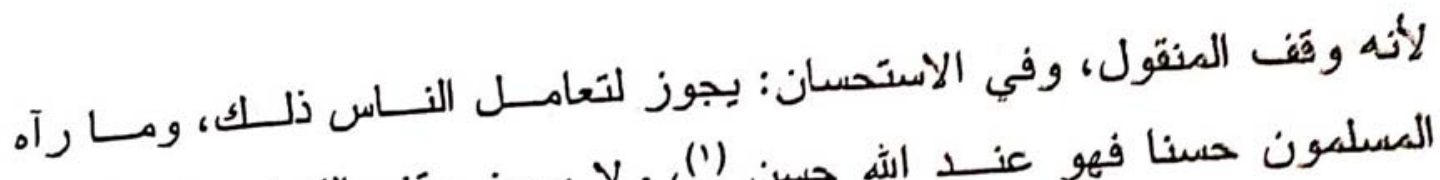

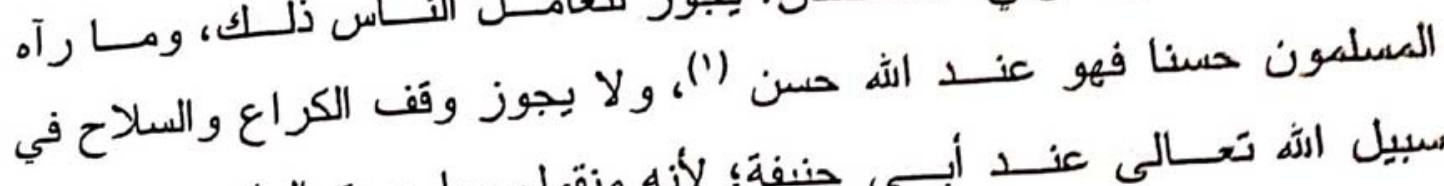

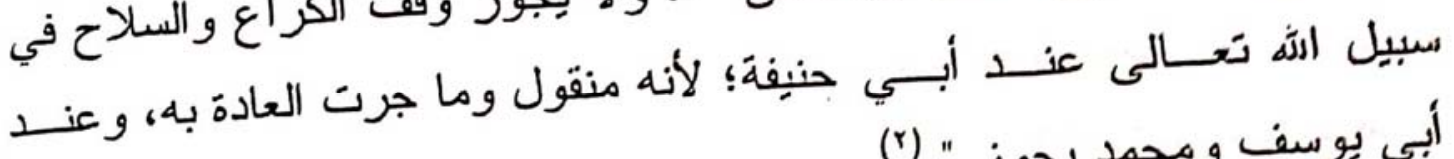
أبي بوسف ومحمد يجوز " (r)

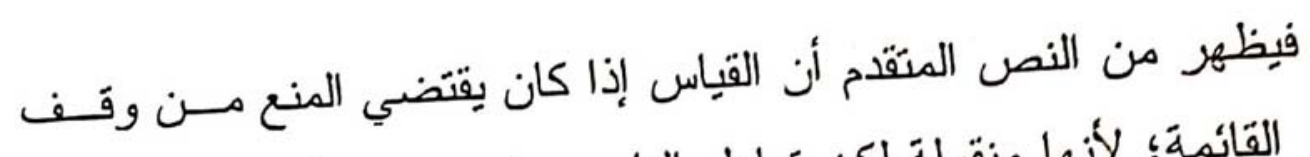

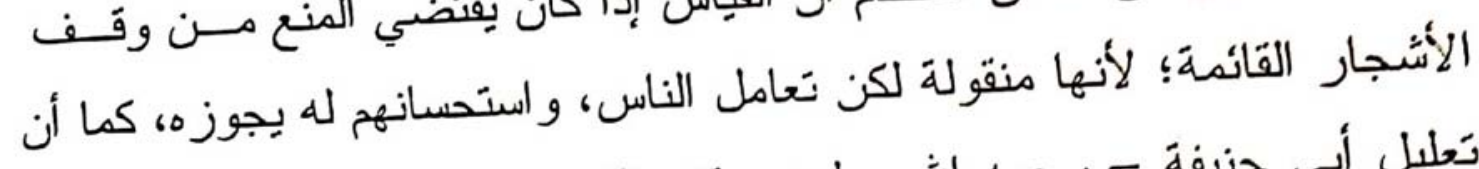

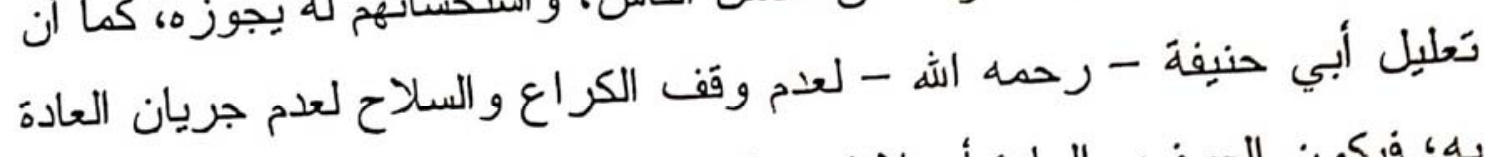
به؛ فيكون العرف و العادة أصلا في هذا الباب.

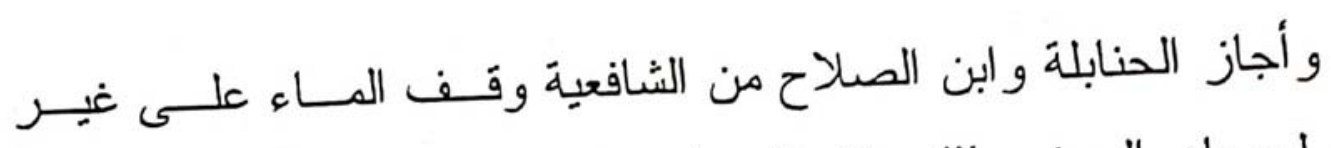
أصولهم لجريان العرف بذللك، قال المرداوي:" ويجوز وقف الماء. نص عليه.

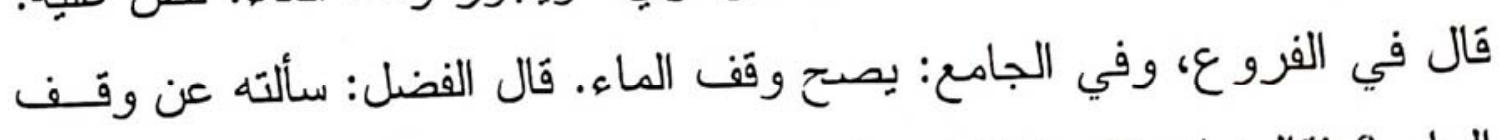

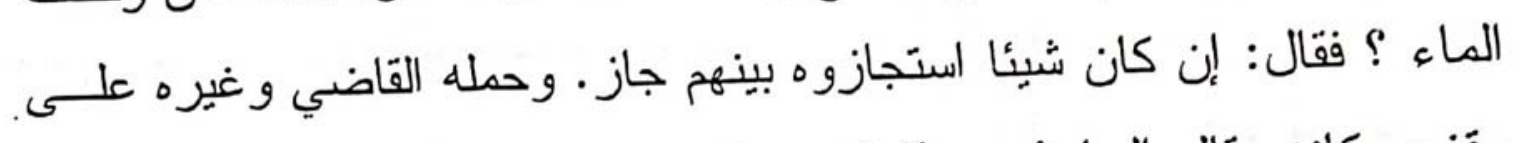
و قَف مكانه. قال الحارثي: هذا النص يقتضي تصحيح الوقف لنفس الماء، كما

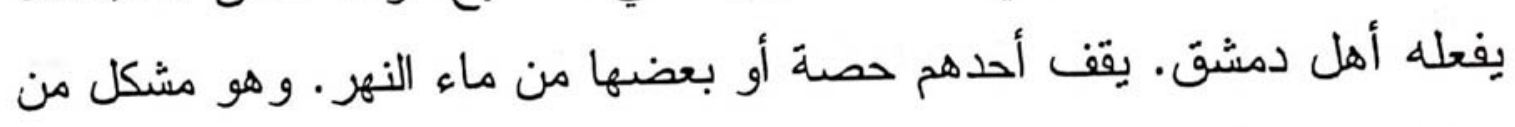

1 - " ما ر آه المسلمون حسنا فهو عند الهُ حسن "أصح الأؤوال فيه: أنه حديث موقوف علــى ابـن مـسعود -

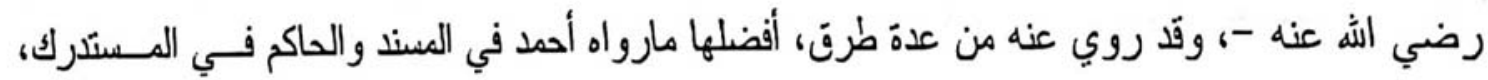

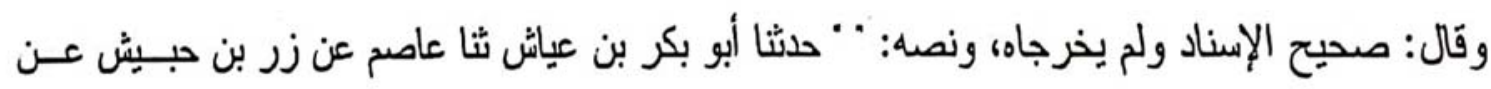

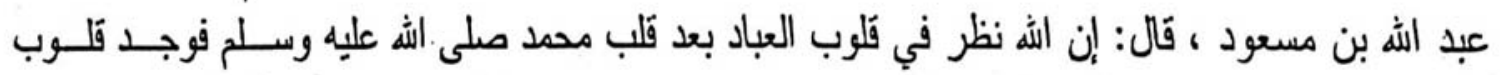
أصحابه خير قلوب العباد ، فجعلهم وزراء نبيه ، يقاتلون على دينه ، فما رآه المسلمون حسنا فهو عنــــ الله

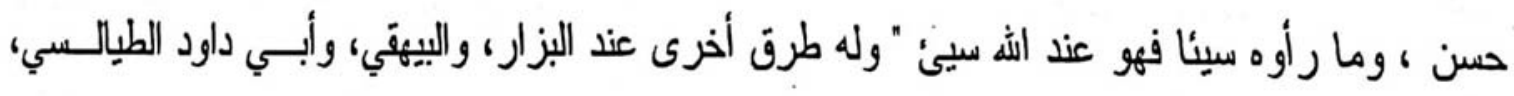
و الطبر اني، إلا أنها لا تخلو جميعا من ضعف. أما رفعه إلى النبي صلى اله عليه وسـلم فقـال الزيلعـي:"

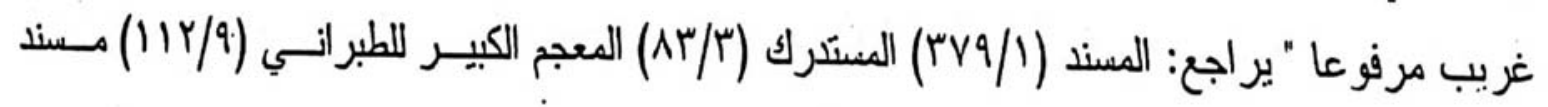

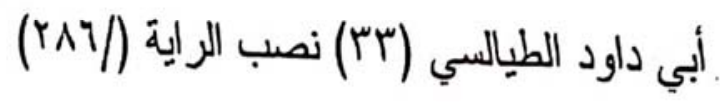

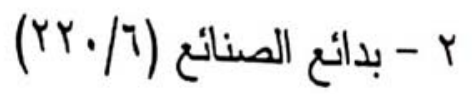




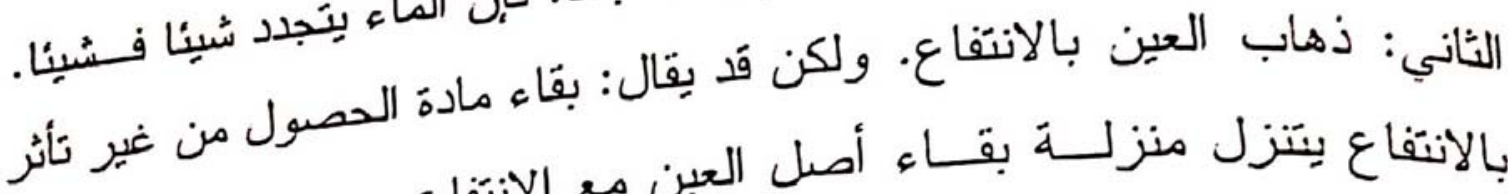

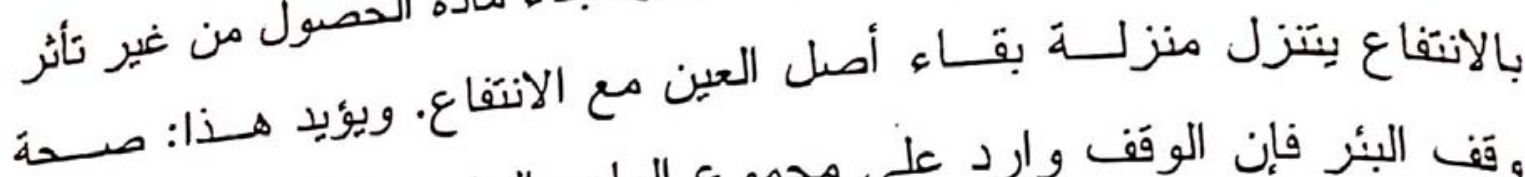

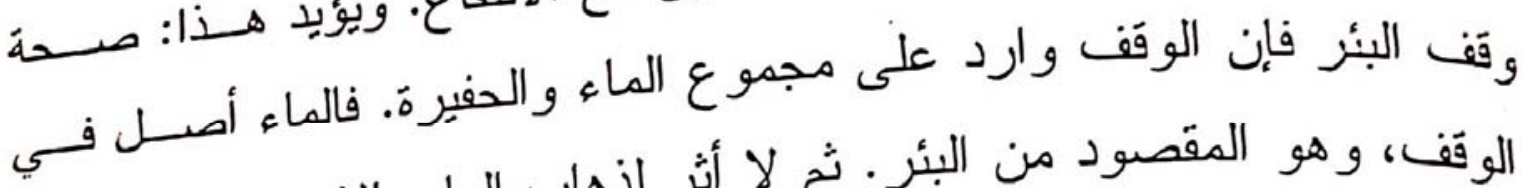

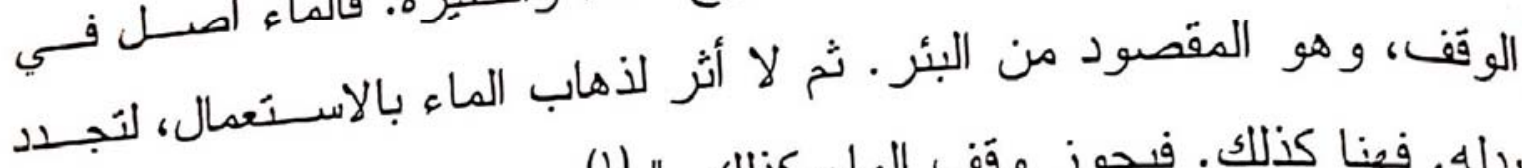

باله. فينا كذلك. فيجوز وقف الماء كذلك. " (1)

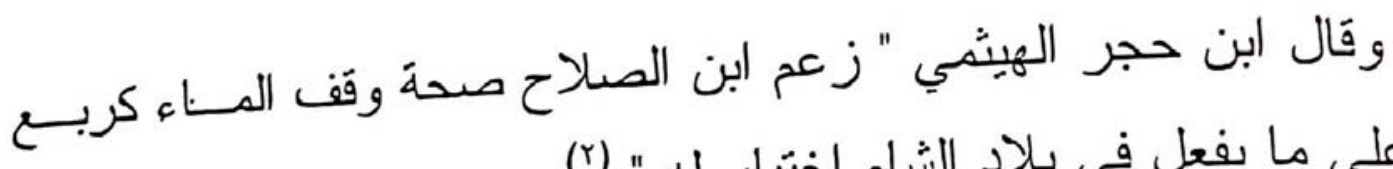

أصبع على ما يفعل في بلاد الشام اختيار له " (r)

فعبارة الحنابلة " إن كان شيئا استجازوه بينهم جاز " و اســتـادهم إلـى

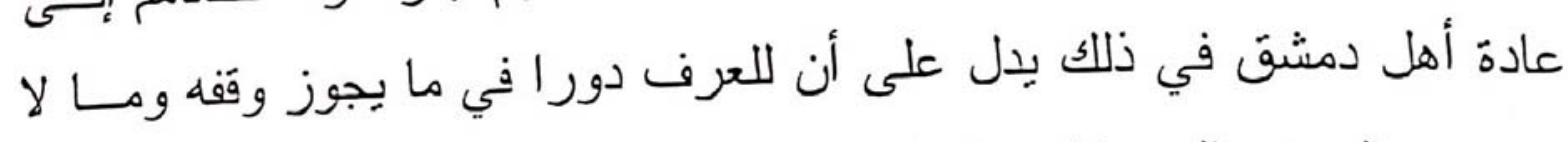
يجوز، و العرف اليوم قائم على اعتبار كثير من المنافع من أعظــم الأهــــال، وتمس الحاجة إليها فيحسن إيراد الوقف عليها شأنها شأن الأعيان.

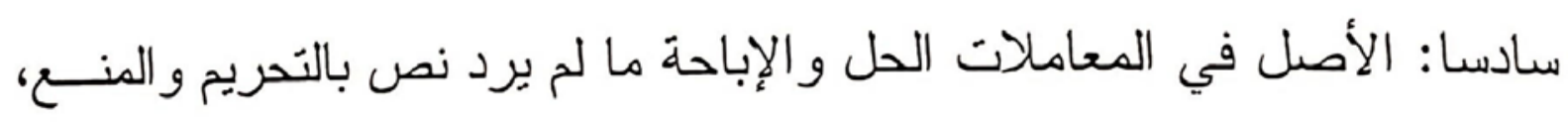
ولم برد منت هذا النص في وقف المنافع فكان مباحا.

ويقتضي هذا الأصل إطلاف الحرية للناس فـي أن بعقــدوا مــن العقـود و التصرفات ما يرون، وبالشروط التي يشترطون غير مقيدين إلا بقيد واحد وهو

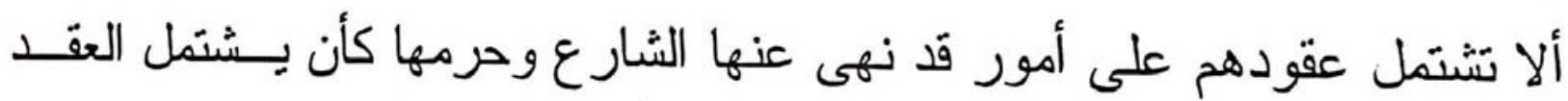
على ربا، أو نحوه مما حرمه الشرع الإسلامي، فما لم تشنمل ثلك العقود علـى أمر محرم بنص أو بمقتضى القواعد العامة المقررة التي تزتفع إلى درجة اليقين

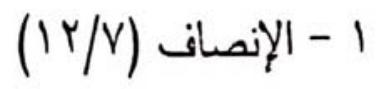

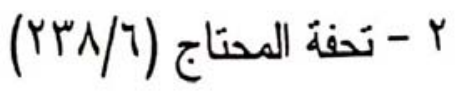



أمر حرمه القطع فإن الوفاء بها لازم، و العاقد مأخوذ بما تعهد به، وإن اشتَملت العقود على فهي

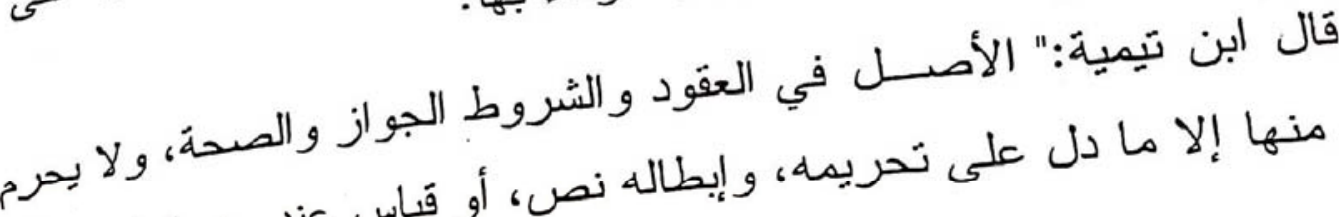

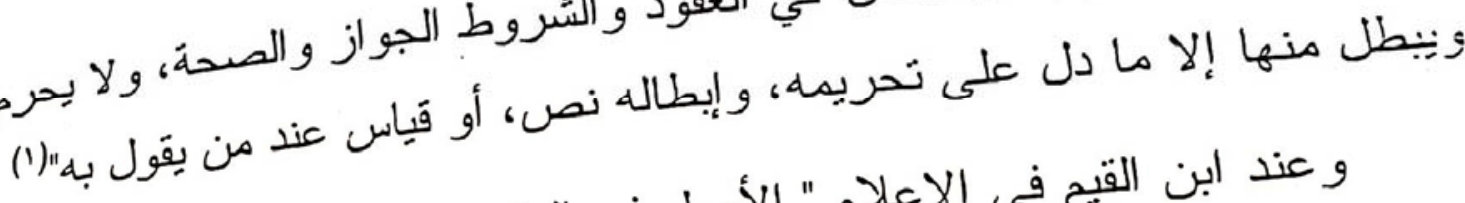

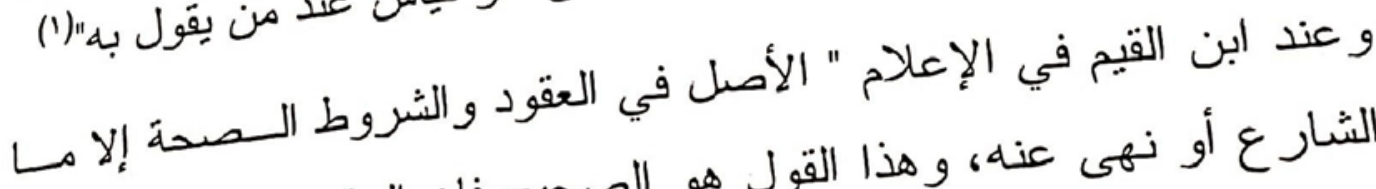

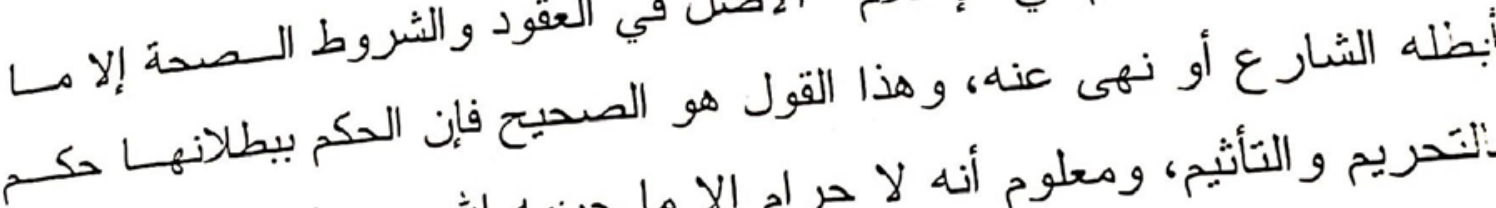

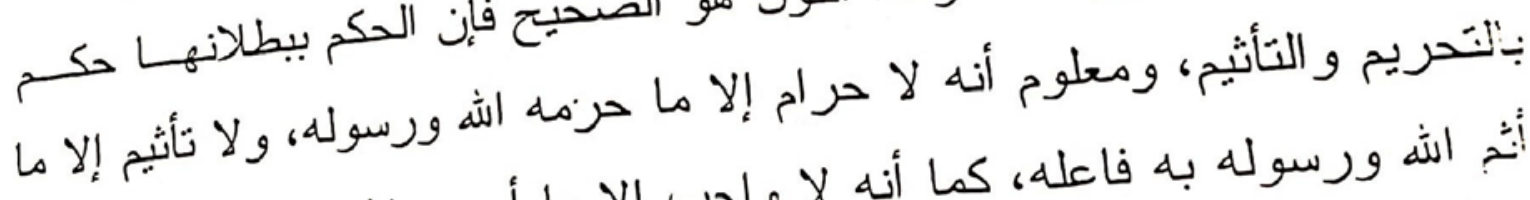

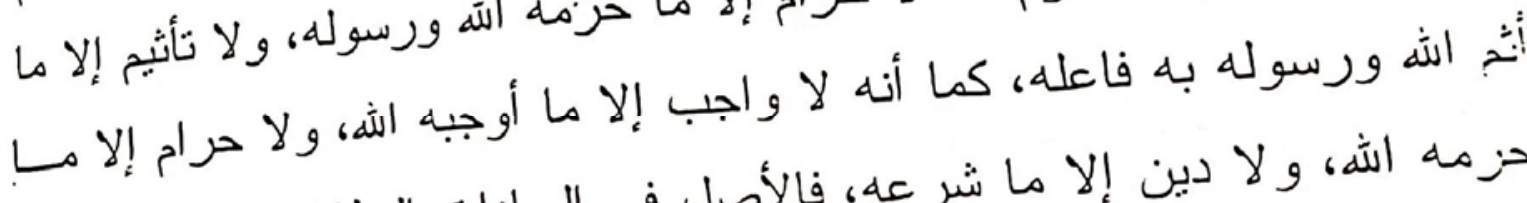

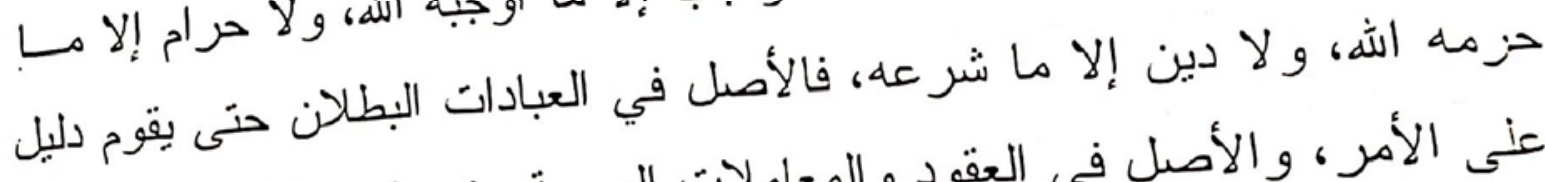
عنى الأمر ، و الأصل في العقود و المعاملات الصحة حنى يقوم دليل على البطلان

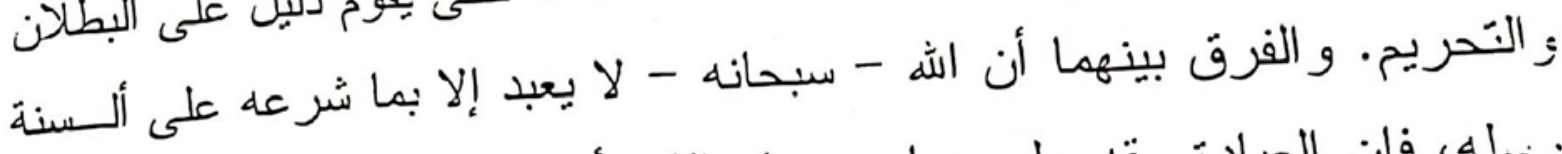

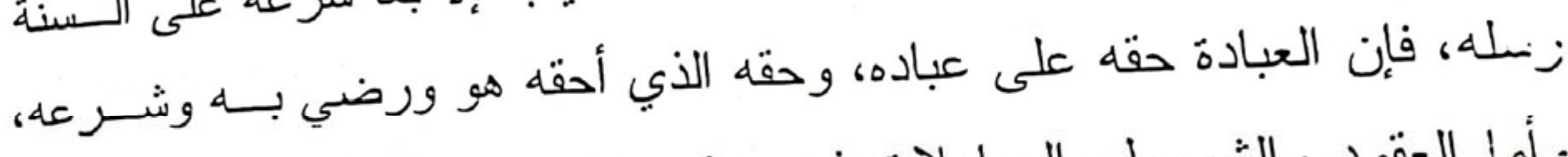

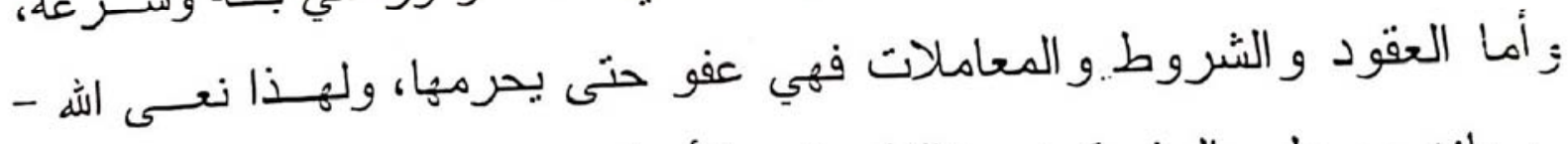
سبحانه - على المشركين مخالفة هذين الأصلين - وهـ تحريم ما لم يحرمسه،

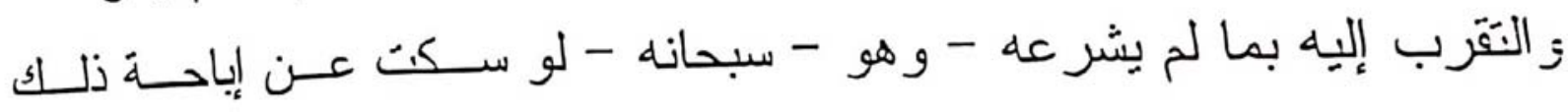
زيَّريمه لكان ذلك عفوا لا يجوز الحكم بتحريمه و إيطاله، فإن الحله ما أحلـهـ الشه، والحرام ما حرمه، وما سكت عنه فهو عفو، فكل شرط وعقد ومعاملة سكت عنها فإنه لا يجوز القول بتحريمها، نفإنه سكت عنها رحمة منه من غير نسسيان و إهمال، فكيف وقد صرحت النصوص بأنها على الإباحة فيما عدا ما حرمه " (r)

( الفتاوى الكبرى لابن تيمية (عq/ع)

r - إعلام الموقعين عن رب العالمين لابن القِيم (1/ roq).

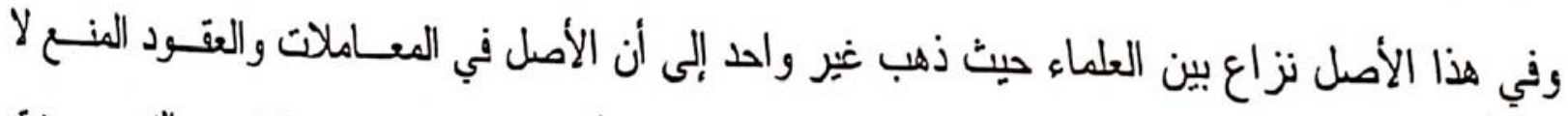

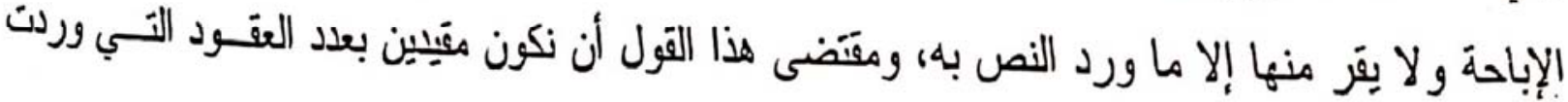




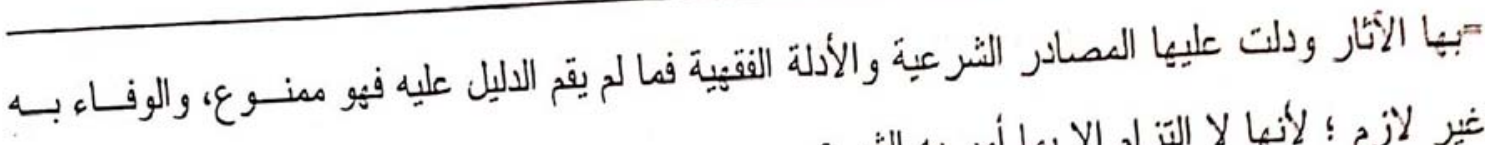

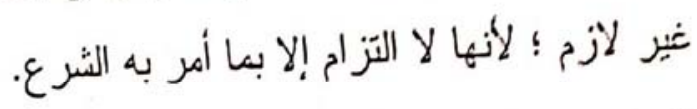

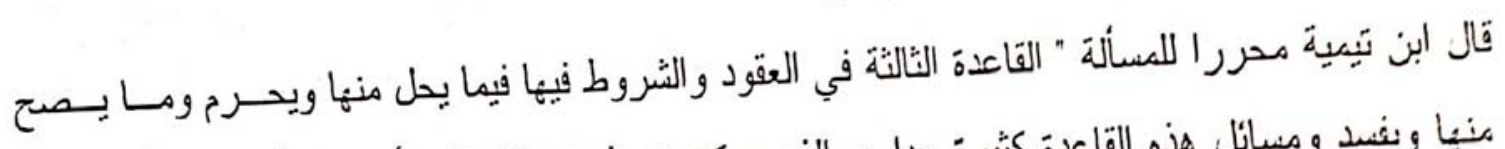

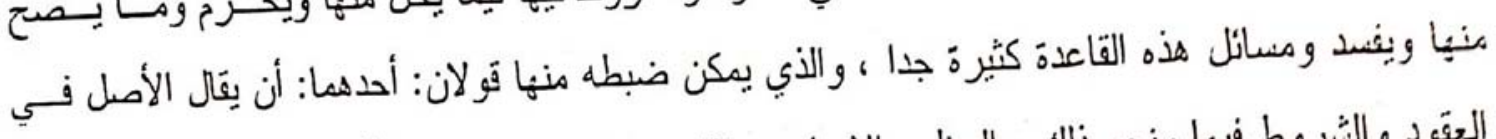

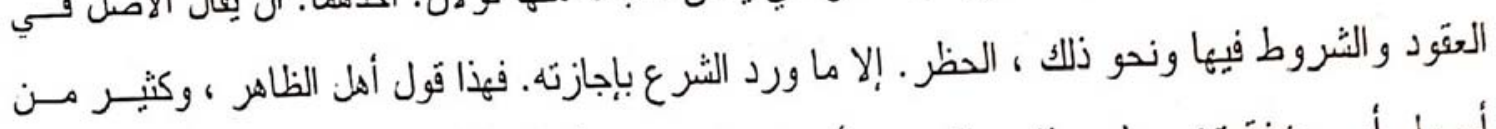

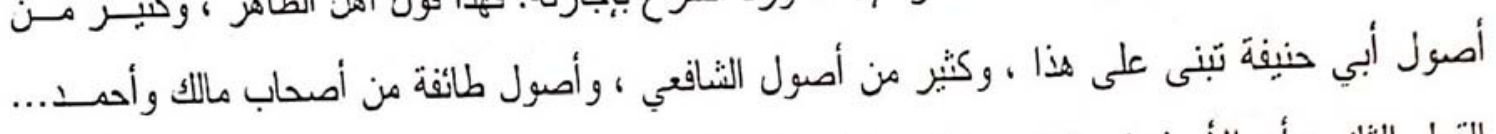

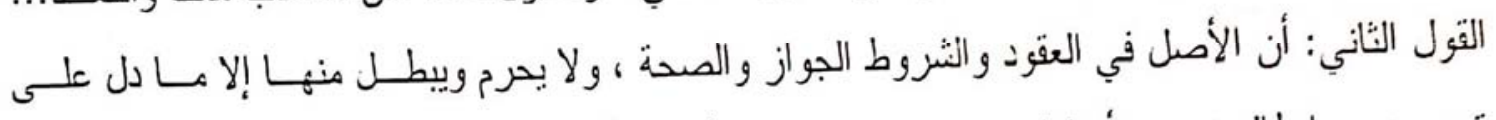

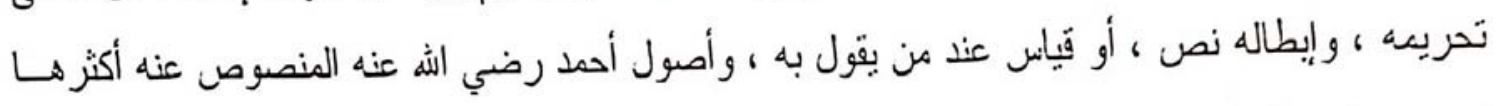

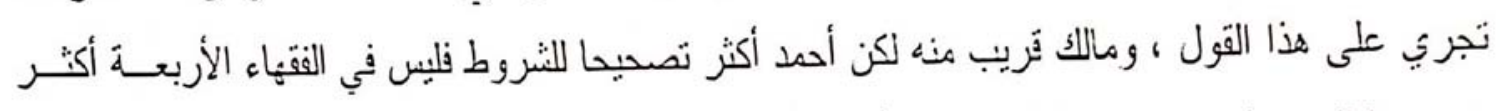

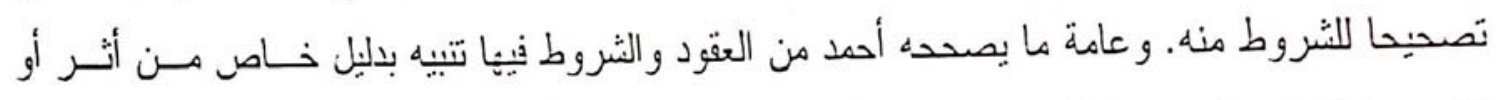

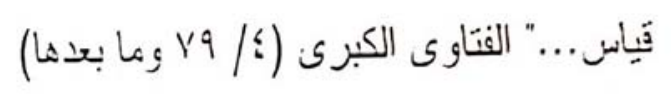

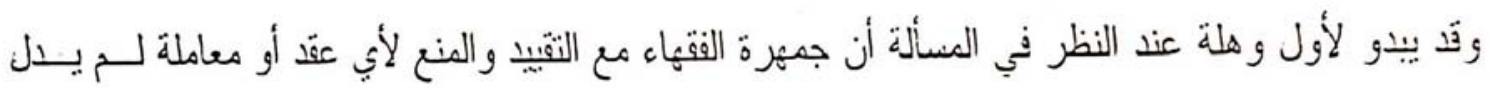

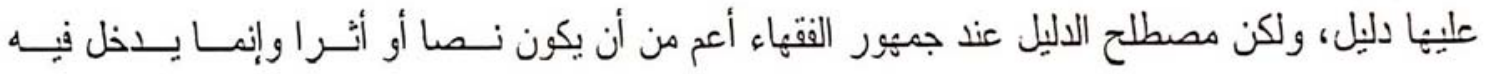
الاستحسان، والمصالح المرسلة، والعرن، وغير ها من المصادر التي تعطي مرونة للشريعة الإسلامية فـي لي استيعابها لكافة المستجدات.

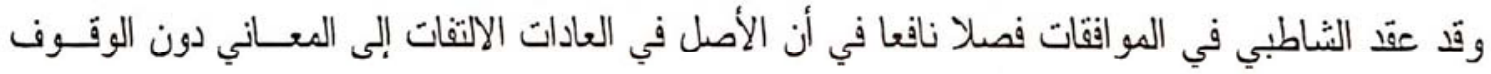

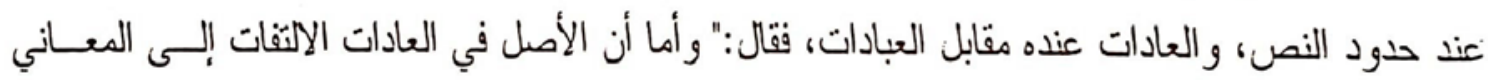

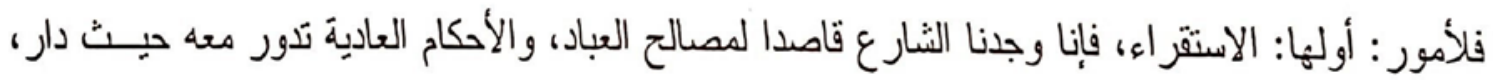

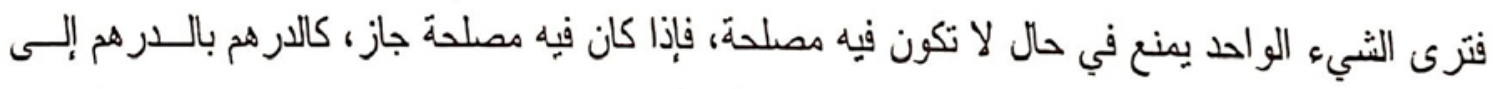
أجل يمنتع في المبايعة ويجوز في القرض، وبيع الرطب ياليابس يمتنع حيث يكون مجرد غرد وربــا مـن فئن

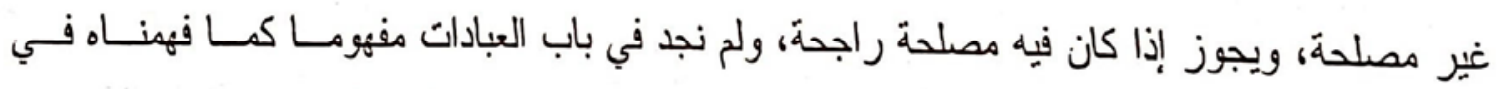

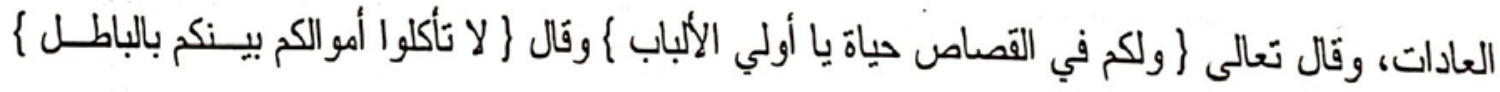

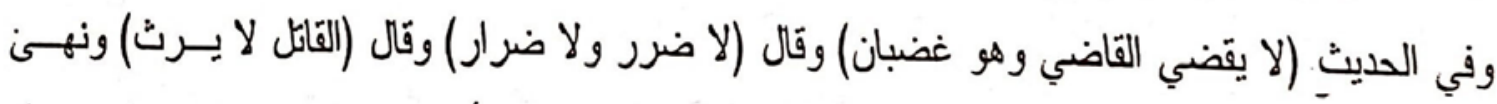

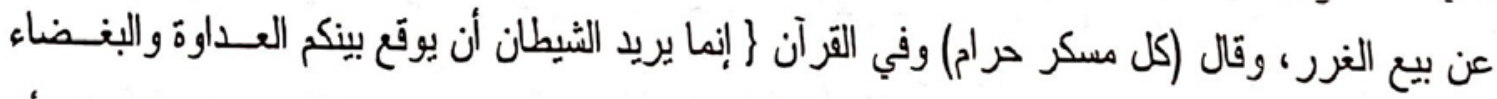

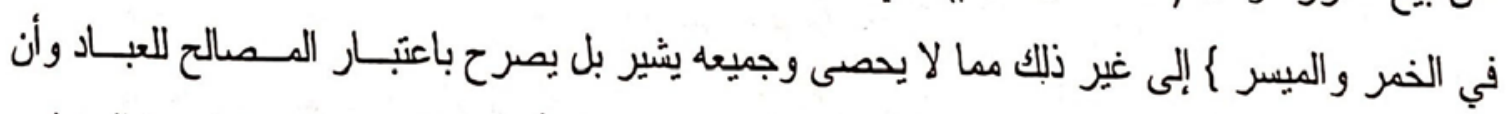

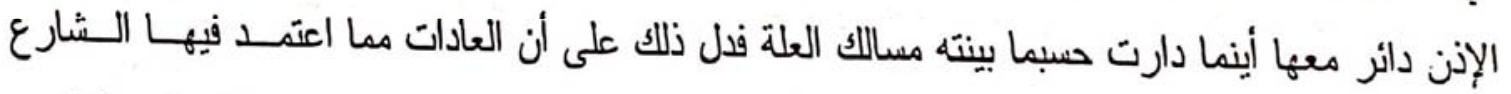

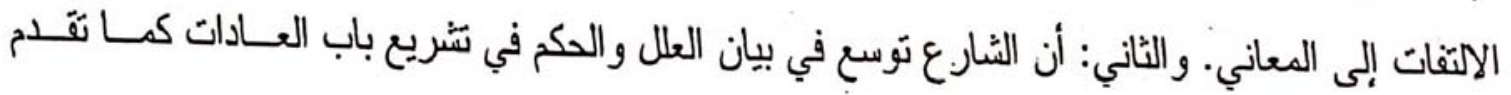


سابعا: تحقيق وقف المنافع لمقاصد الشريعة المعتبرة في بــاب القربــات، و اشتماله على مصالح من غير مخرة تلحق بالناس فيكون مشروعا، وهو لبس فيس

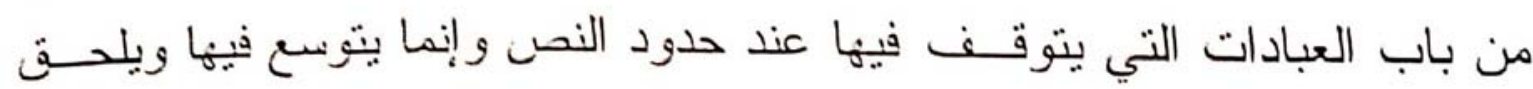

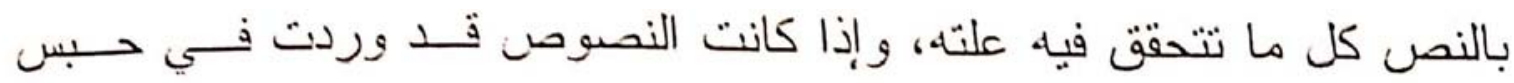

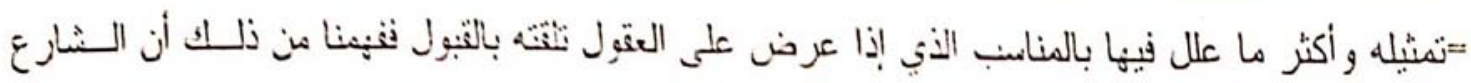

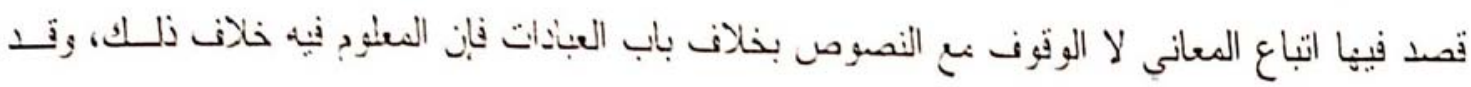

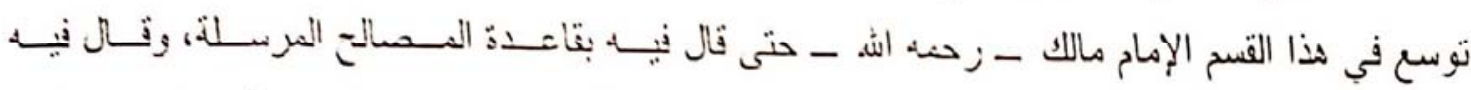

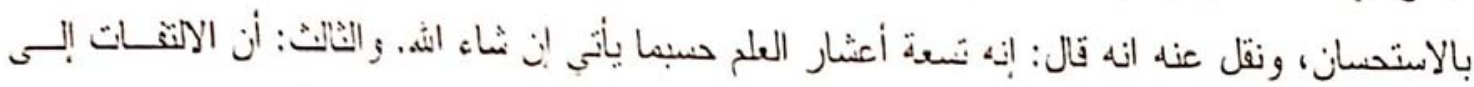

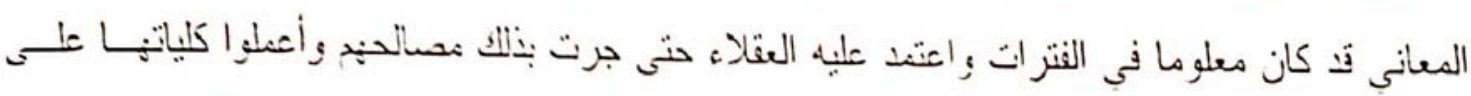

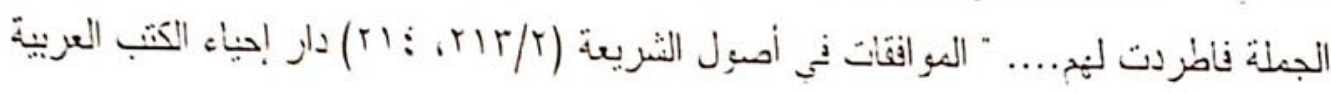

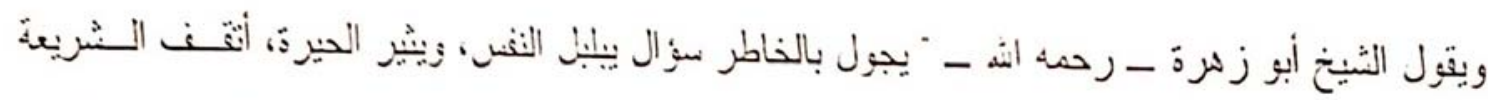

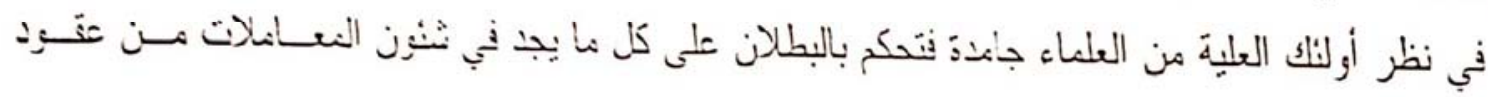

وشنروط

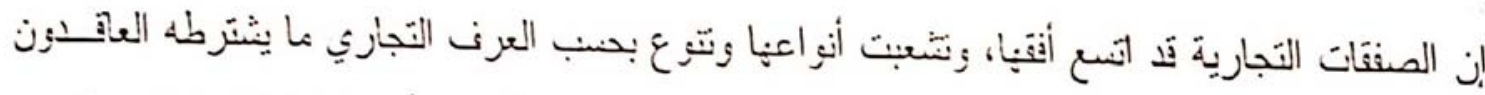

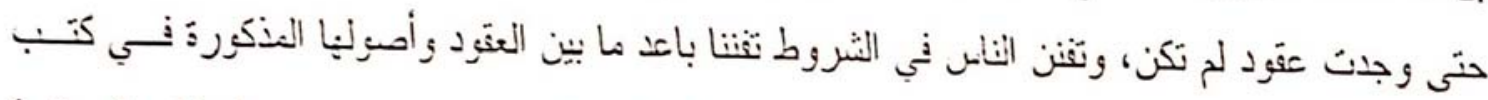

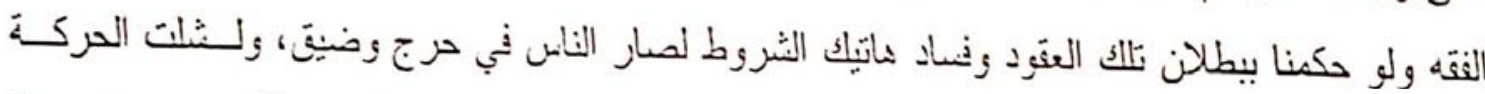

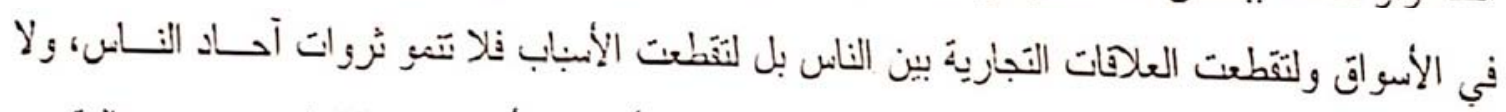

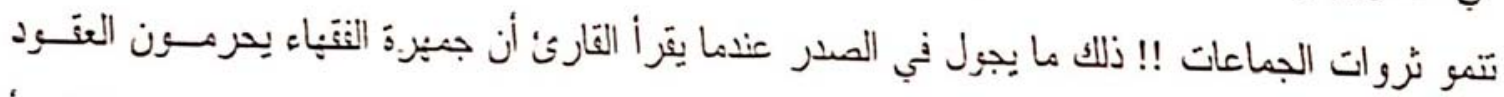

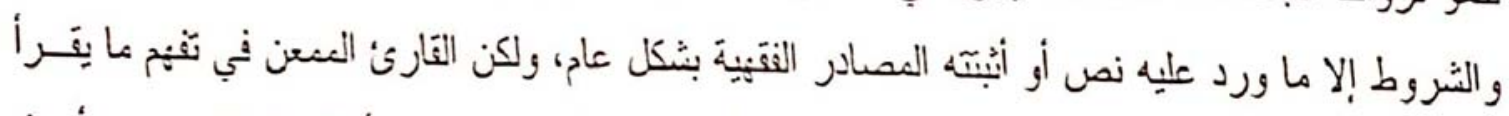

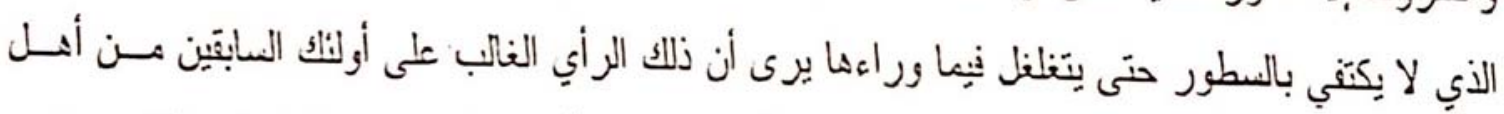

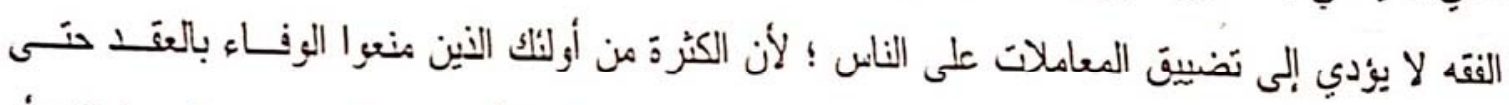

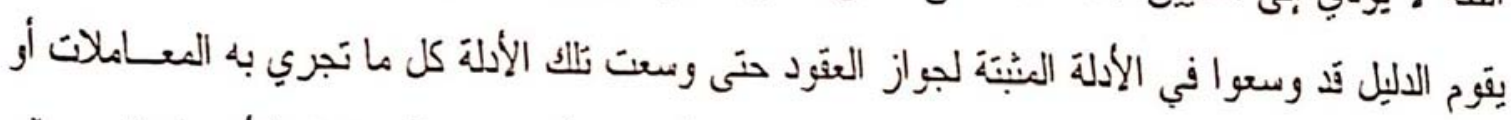

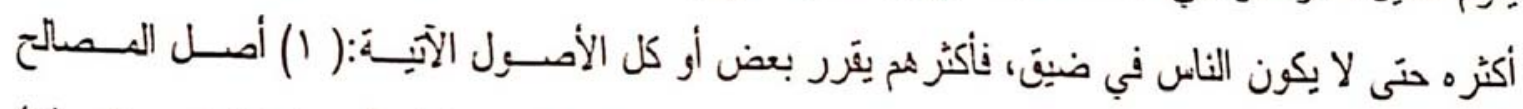

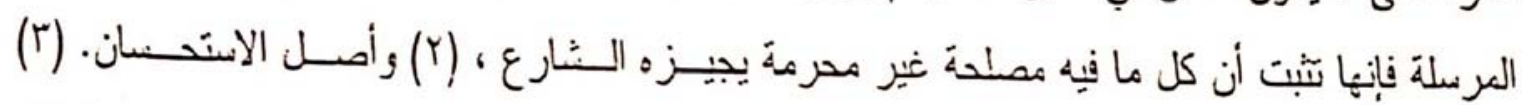

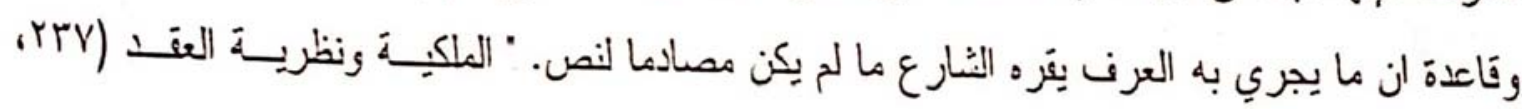


الأصول فيلحق بها حبس غير ها مما لم برد فيه نص بالمنع.

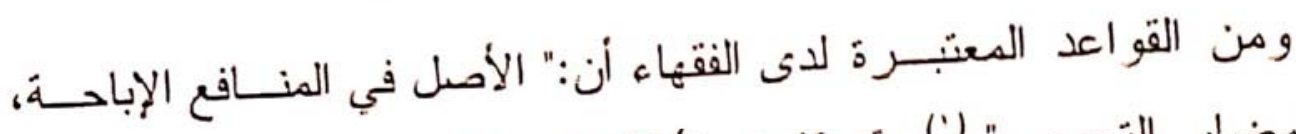

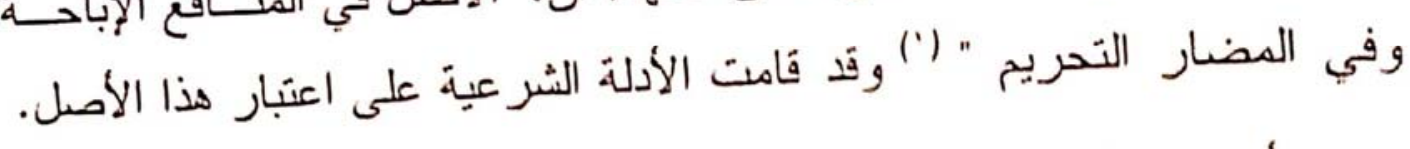

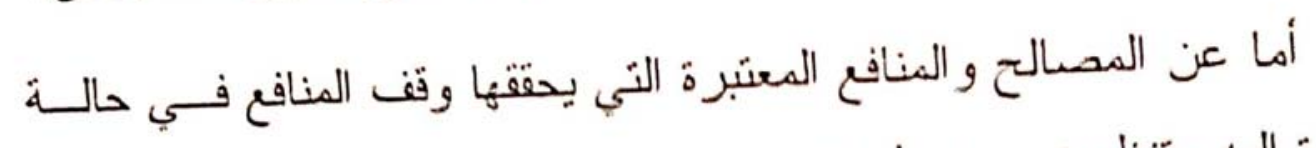
الدعوة إلبه وتتظليمه ووضبطه فنوجز ها فيما يلي:

أولا: مشتملات وقف المنافع، وحجهها في المجتهع.

تختلف الخريطة المالية للمجنمعات المعاصرة عما كانت عليه مسـن فبــل؛

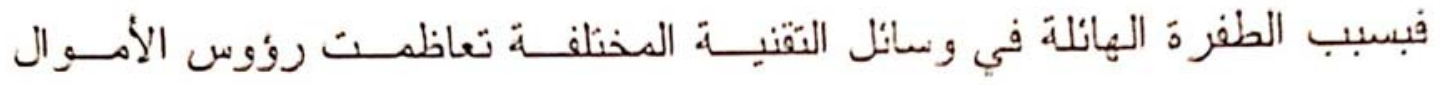

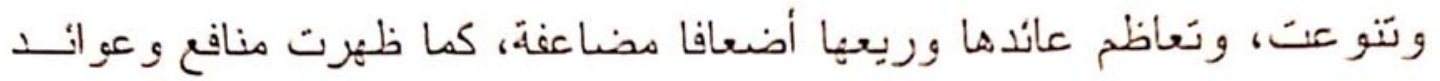

$$
\text { و غلات لأصول الأمو ال لم نكن معروفة سلفا. }
$$

ولذلك فان حجم المنافع النَي ينَّقع أن يرد عليها الوقت في حالة الــدعة إليهه و تنظيمه حجم ضخم هائل من حيث الكم و الكيف، و على سبيل المثنال:

ا ـ منافع السكنى، وهي من أكثر المنافع التي تَس الحاجة إليها في العصر

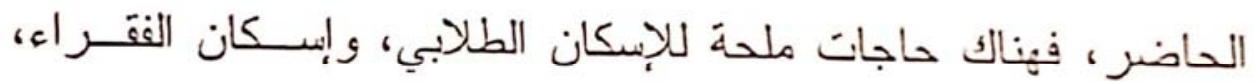
ودور الأيتام، ور عايةَ اللقطاء، والمسنين، ويمكن لنخص مسافر مثّل

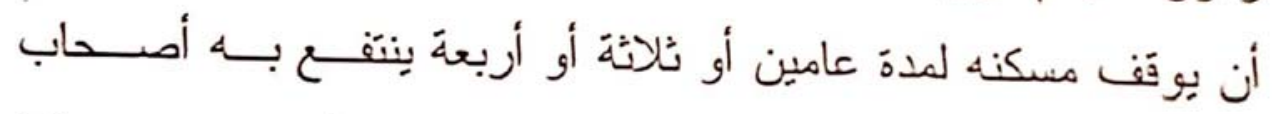
الحاجات وبعد انتَهاء المدة يعود إليه مسكنه، وقَد يملك شخص مس عسكنا

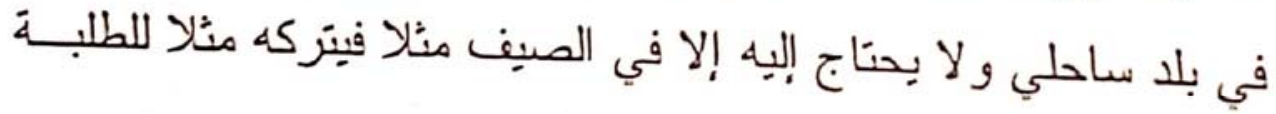
فترة الدراسة ليعود إليه وقت احتياجه إليه......

$$
1 \text { - البحر المديط للزركثي (؟/1؛)، شرح الكوكب المنير (اrا؛) }
$$


r. منافع وسائل النقل و المو اصلات وهي أعظم مــن منفعــة الركــوب

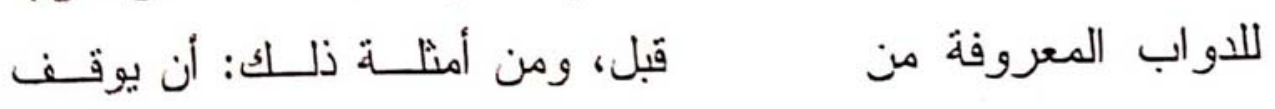
شخص سيارة لنقـل الطلبة او نحوهم إلى معاددهم ومقار در استهم في الصباح وبعد الظهر على أن ينتفع بسيارته في غبر هذه الأوقات فنتحقق بذلك مصلحة الجميع.

r. منفعة العمل من العمل و الفنيين و المهنيين بكافة تخصصاتهم المختلفة: الطبية، و الهندسية، والإبدارية، و الإعلامية.... ؛. . منافع الكهرباء، وخظرط الهاتق، و الفاكس، و البرق، و التلكس... ه. منافع الأجهزة و المعدات المختلفة المستخدمة في الإنتاج أو النوزيـع، أو الترفيه، أو التعليخ آ. منافع الأجززة التعبيضية للإنسان.

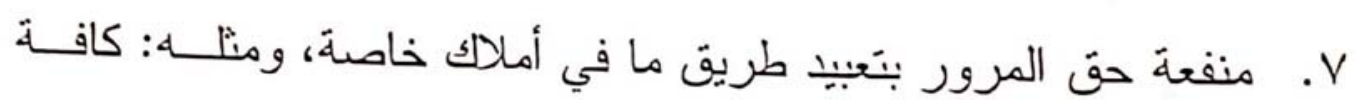
حقوق الارتفاق المختفة كحق الشرب، و الري، و الصرفئ....

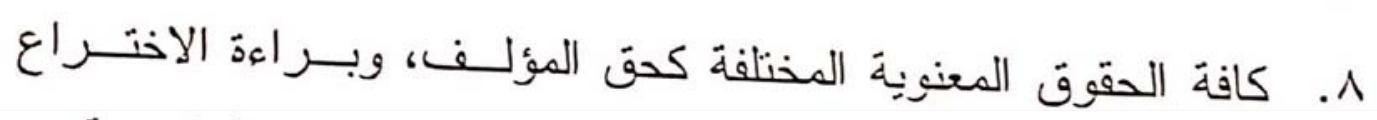
و الابتكار ، والاسم التجاري، و العلامة التجارية، و البر امج الحاسوبية..... 9. منافع القنوات الفضلئية، وشبكات الانتزنت.... • 1 . منافع القز اعة و التعلم للكتب و البر امج المختلفة. إن ما ذكرناه هو قليل من كثير مما تشهده الساحة المالية المعاصرة، ومهـا قَّ تشهده بعد ذلك ربما يكون أضعاف ما هو موجود. 


\section{ثانيا: الحاجات التي يشبعها وقف المنافع.}

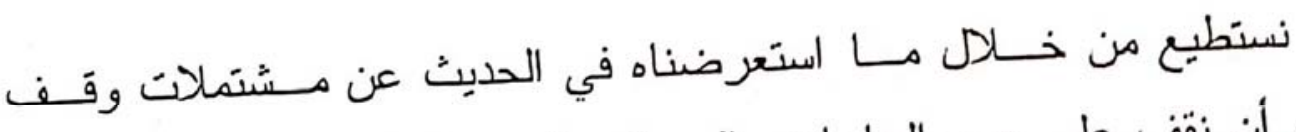
المنافع أن نقف على حجم الحاجات و المصالح التي يحققها؛ حيث نجد أن كثيرا

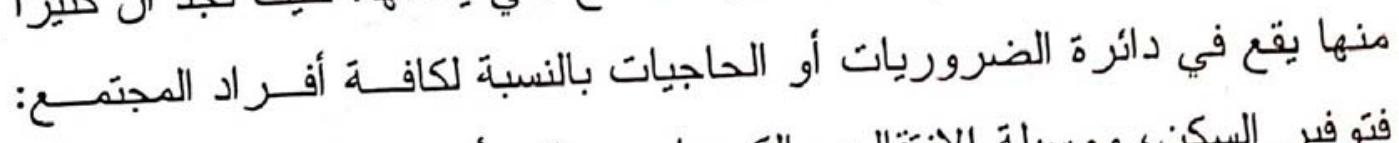
فنوفير السكن، ووسيلة الانتقال، و الكهرباء ــ التي أصبحت في كثير من الأحيان

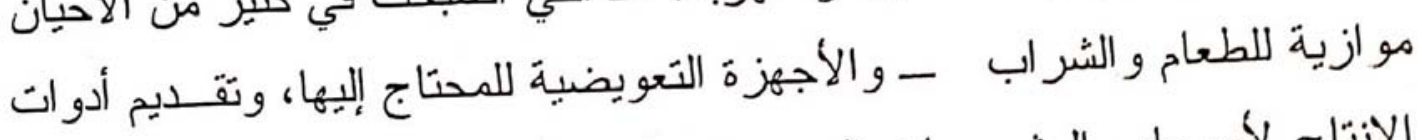

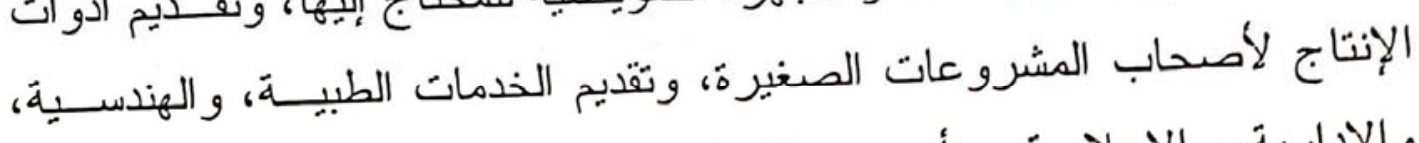

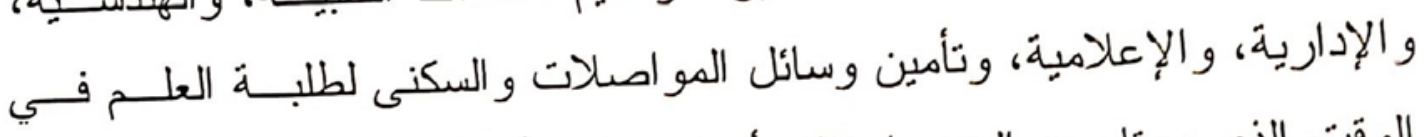

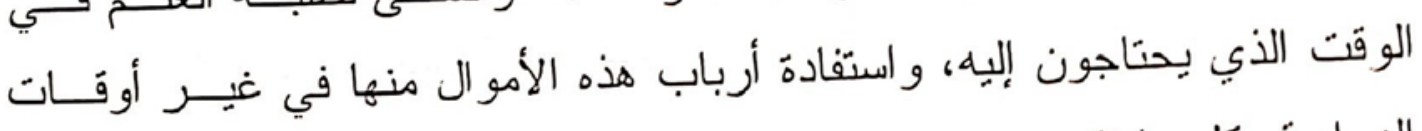

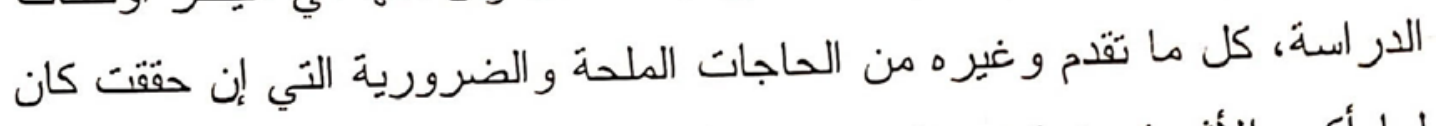

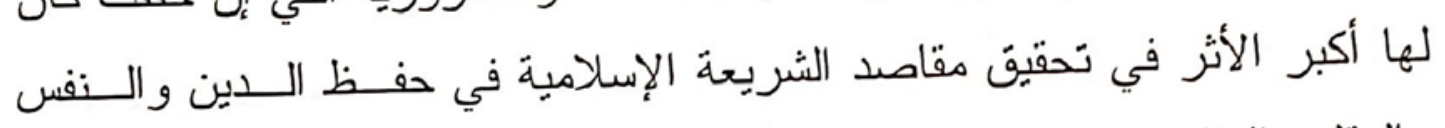
و العقل و المال على مستوى الفرد و الأمة. تالثا:المستفيدون من وقف المنافع.

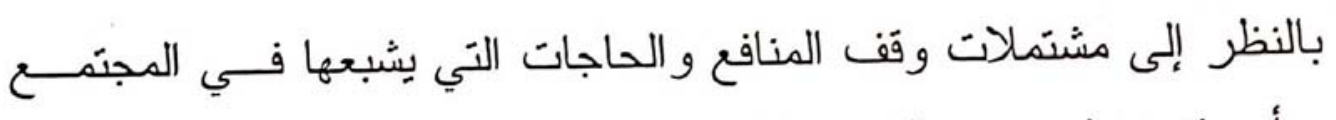

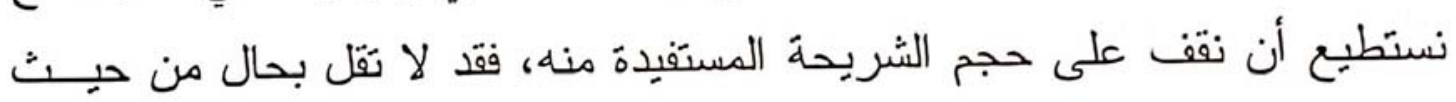

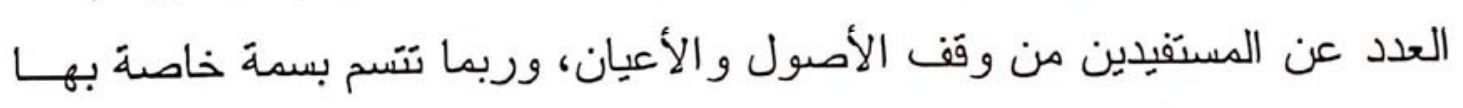
و هي الحاجة الأكثر إلحاحا كما عرضناها في المسأللة السابقة.

وبعد عرض ما ثقدم من خلاف ومناقشة فإن الذي يظهر رجحانه ما ذهب إليه المالكية وما مال إليه ابن تيمية من جو.ز وقف المنافع؛ لعدم وجود ما بِـدل

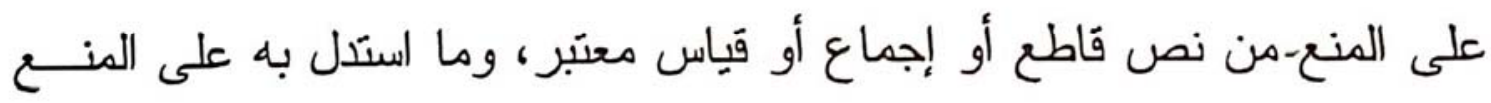
ليس صريحا في المنع، و لا بِمكن إبطال عقد يحقق كثبر إمن المــصالح ويــدفع

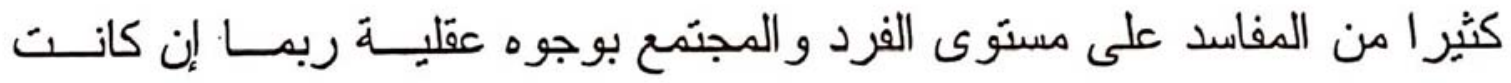
مناسبة في وقت ما فليست مناسبة في وقتنا الحالي لشدة الحاجة إلى تجويز هـذذه 


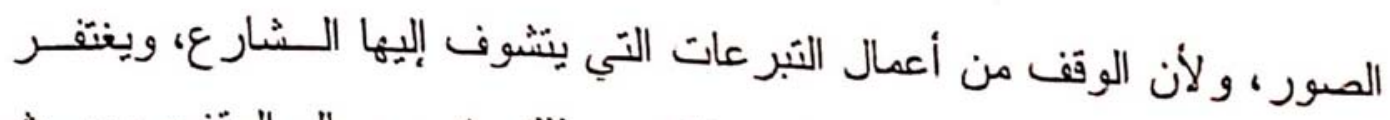

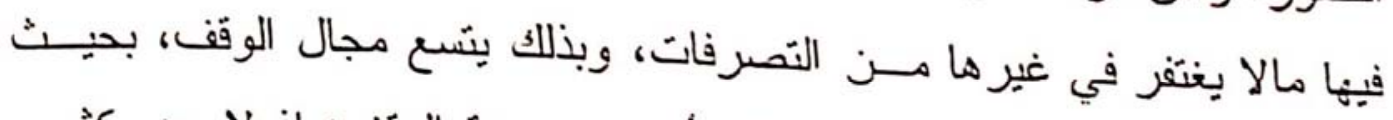

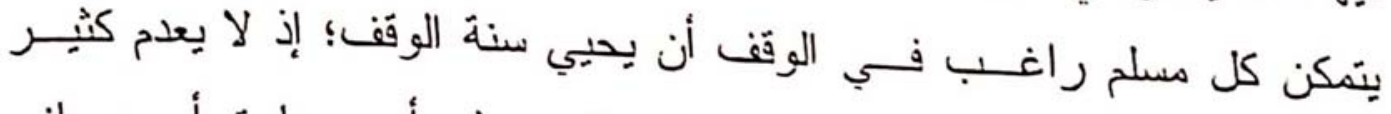

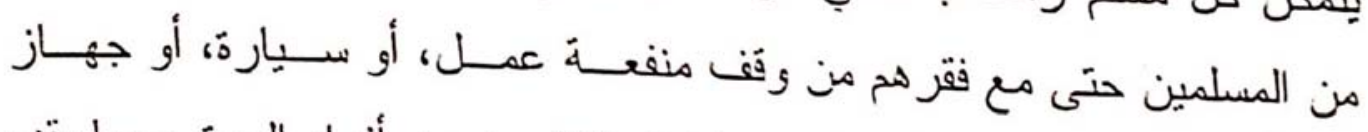

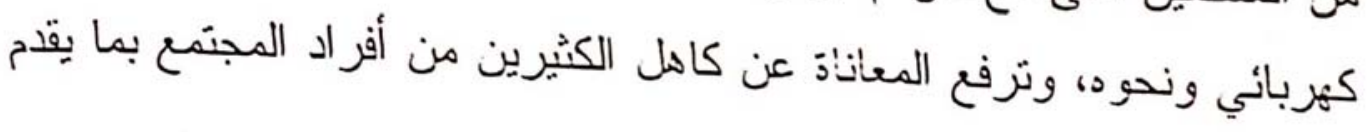

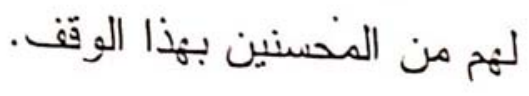

من المنافع الموقوفةَّج

و الجواب: أن ثمة فو ائد المالكك من ذلتك، منها:

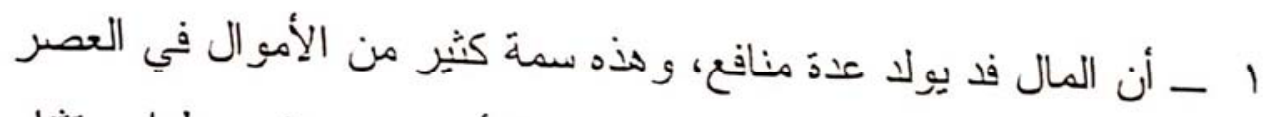

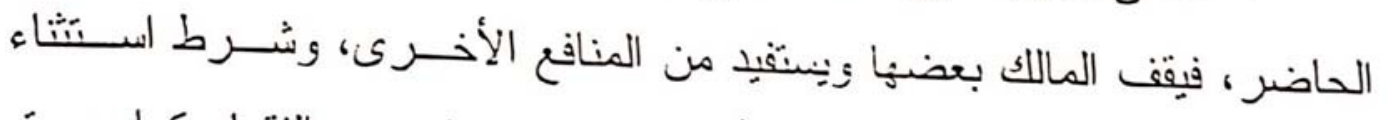

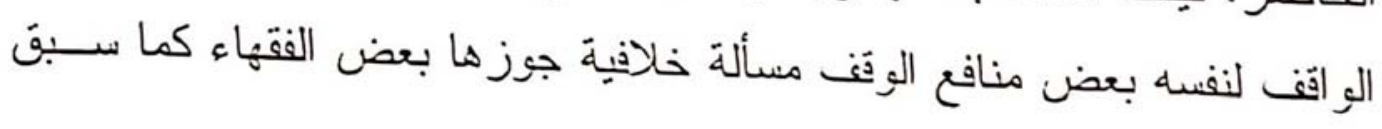
عرضه.

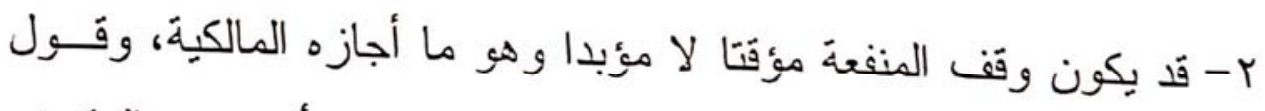

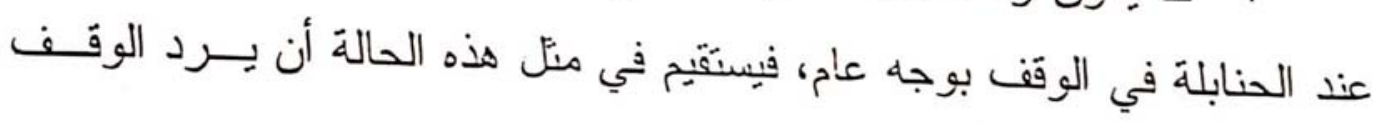

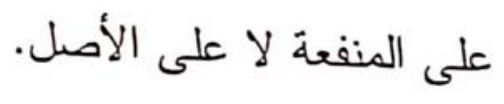

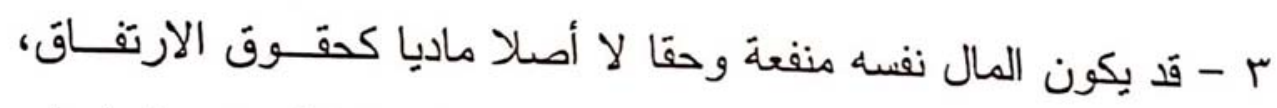

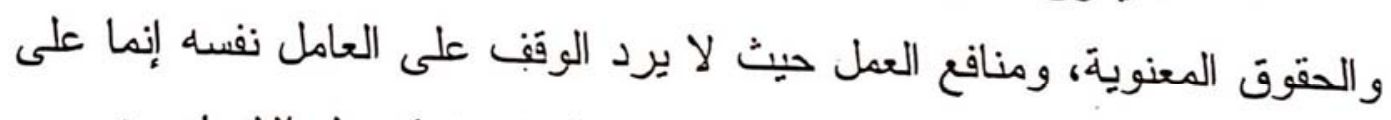

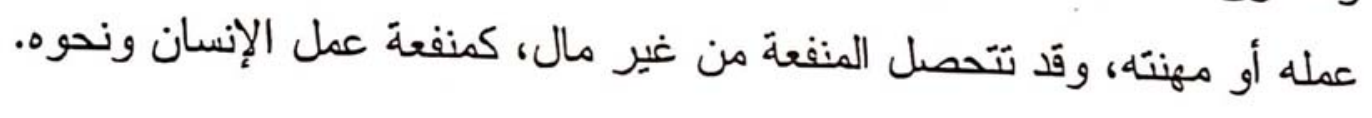
ع- في وقف المنافع دون الأصول حماية للأموال من التعرض لها من قَبل بعض الحكام والسلاطين الإنين ينجر أون على أموال الأوقان. 
ه - التملك غريزة فطرية في الإنسان حنى ولو لم يستفد المالك منه ثُرة

مباشرة، فتجويز وقَف المنـافع دون الأصول يحقق مصلحة المالك في استئداره

بالملك، ومصلحة الفقراء فـي الانتفاع بالمال. 


\section{المبحث الثالث}

\section{شروط وقف المنافع}

إن القول برجحان جواز وقَف المنافع سواء أكانت منافع الأشــخاص أم

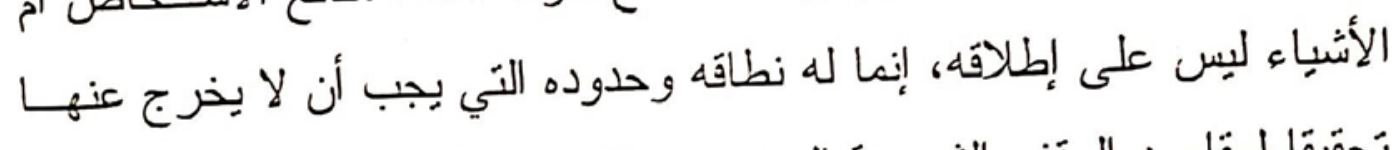

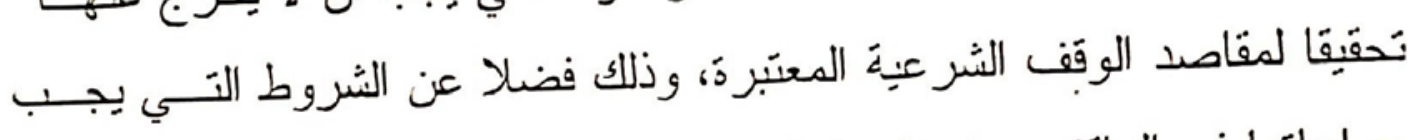
مر اعاتها في الو اقف، وفي الجية الموَّرف عليها، وفي صينته.

$$
\text { ومما يجب مراعاته في وقف المنافع: }
$$

أولا: أن تكون المنافع من أصول مباحة شرعا.

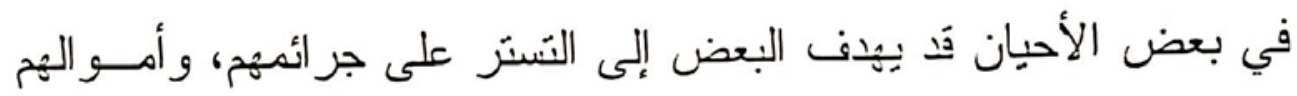
الخبيثة المحرمة، فيوظفون جزءا من غلاتها في وجوه البر والإحسان، مثل قيام لصوص المال العام، وناهبي أمو ال الأمة، وتجار الممنوعات، وكافة العصابات

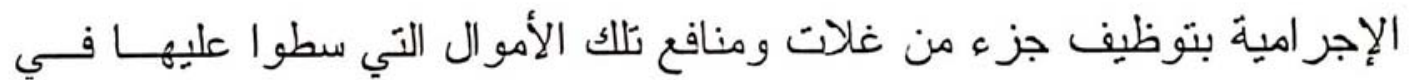
وجوه البر و الإحسان المختلفة.

ومن ذلك مثلا: قيام تَجار الخمور و المخدرات و السلع المنتهية الــصلاحية و الملوثة بالنفايات النووية و أثباههم بوقَف جزء من أرباح تجارتهم المحرمة فهذا

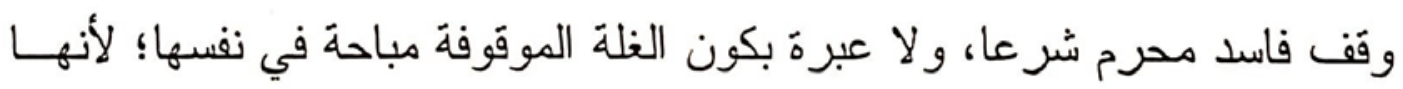
تولدت من أصل محرم، ومتله: وقف المرتشين وناهبي المال العام، وغاصــبي أمو ال الناس لجزء من أرباح استثمار اتهم في تلك الأموال المنهوبة، ويعد الوقف في هذه الحالةَ صورة من صور غسل الأموال، بهذف التغطية على جرائمهم. وقد وردت نصوص شر عية كثِرة تمنع التعامل فـي الأمــو ال الخبيثــة و المحرمة بأي وجه من وجوه التعامل، سو اء أكان خبثها في عينها أم من جهـــة كسبها، وسواء أكان التعامل من قبيل المعاوضات أم قبيل التبرعات، ومن ذلك: 


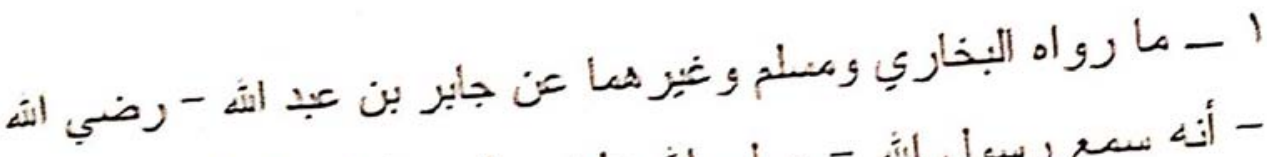

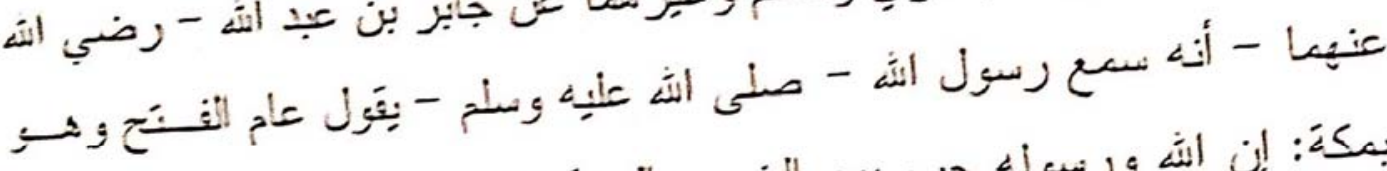

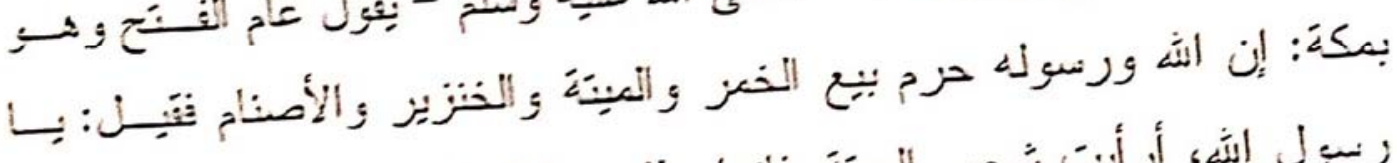

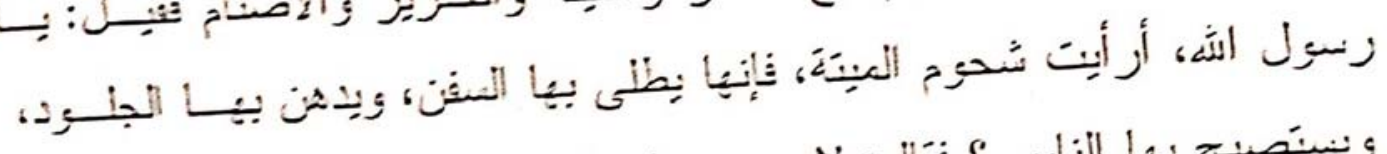

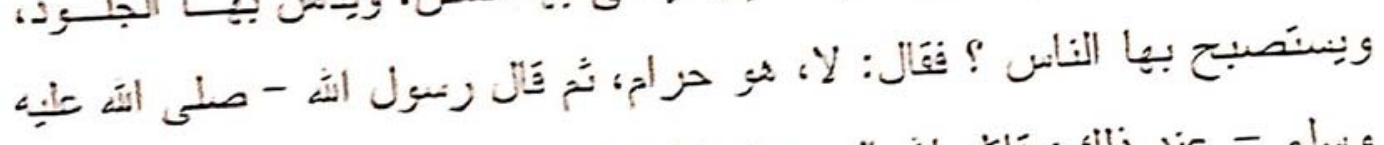

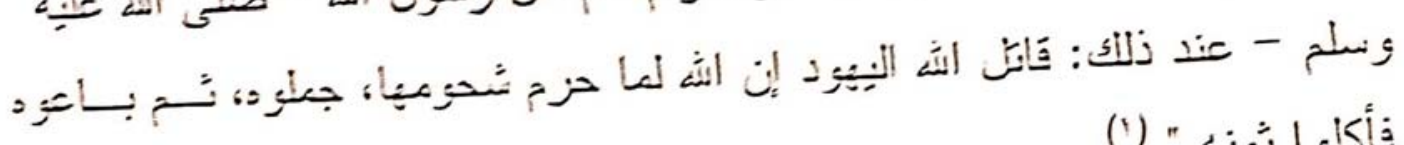
(') " فأكلى انثنة

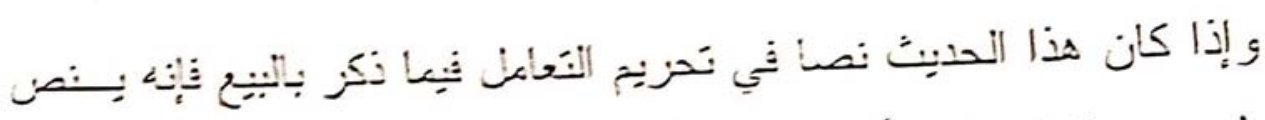

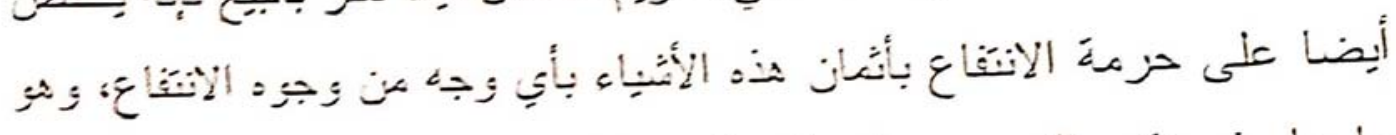

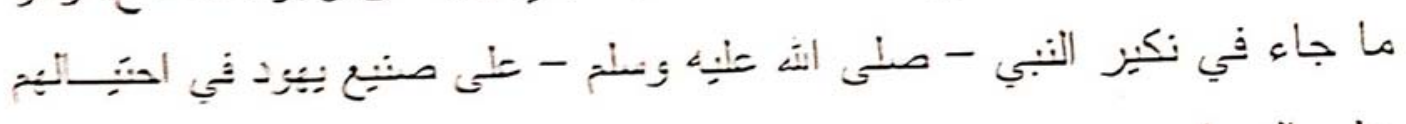
على الحرام.

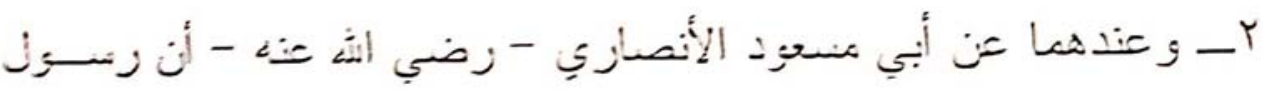

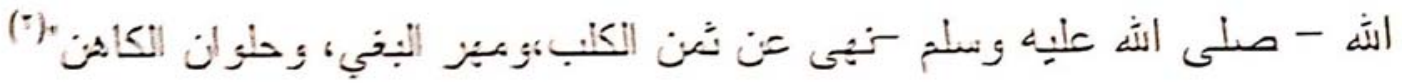

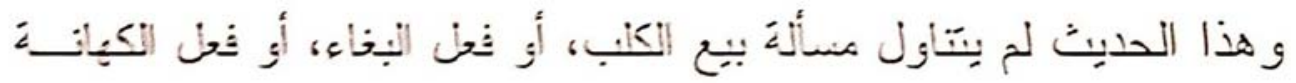

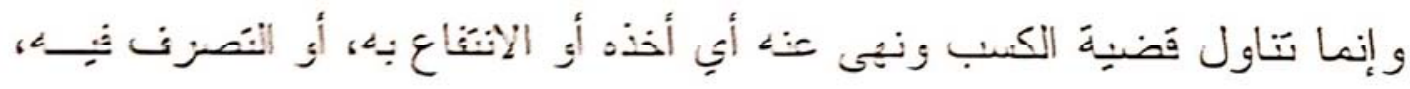

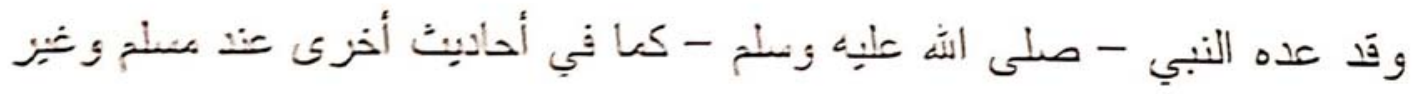
ه بأنه من شر الكنب، و أنه خبي.ت.

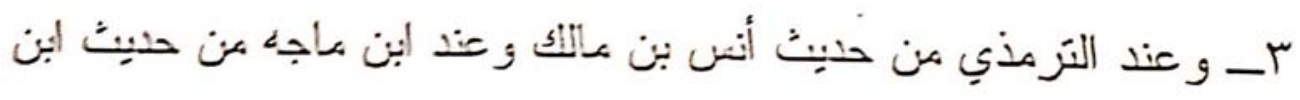

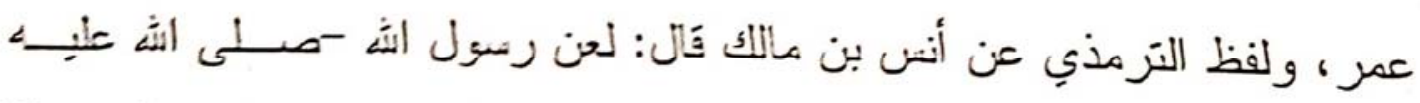
وسلم - في الخمر عثرة: عاصرها، ومنتصرها، وشاربيا، وحاملهاء والمحمولة

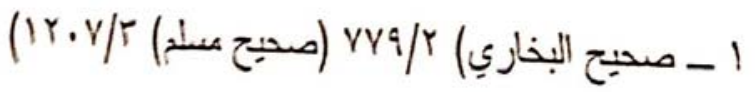

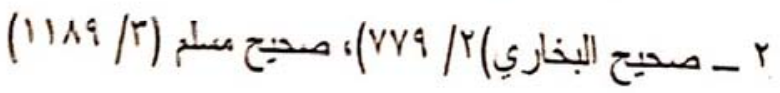




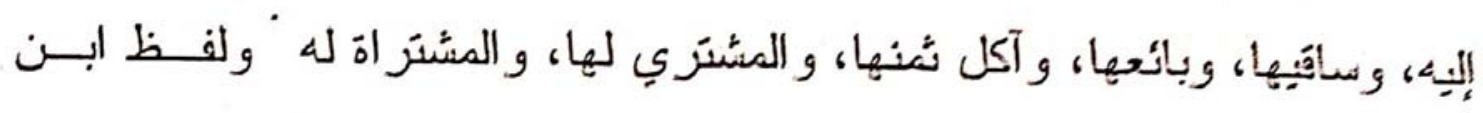

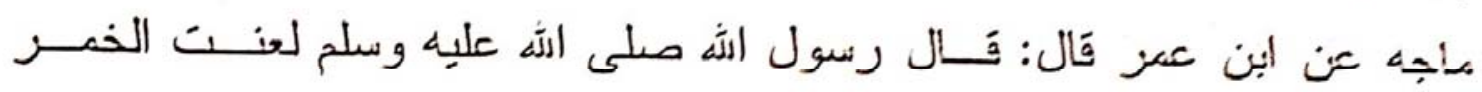

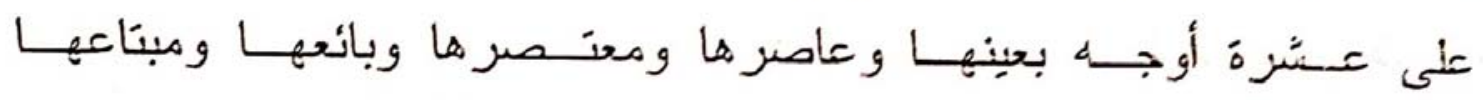

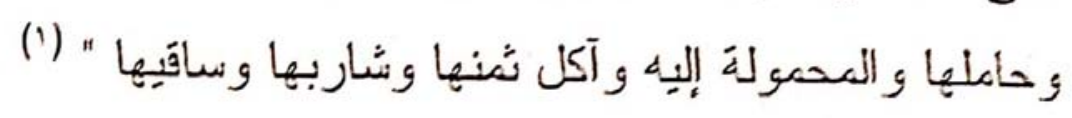

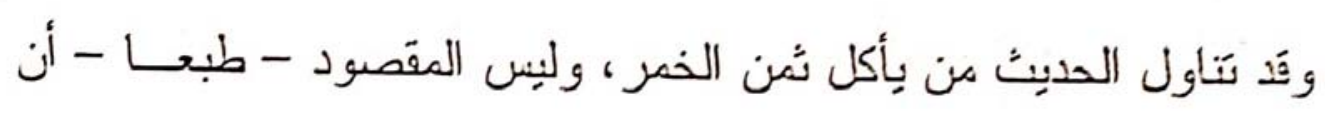

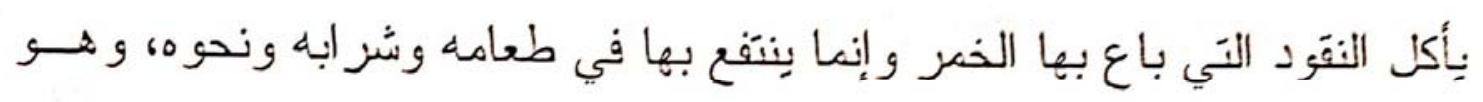

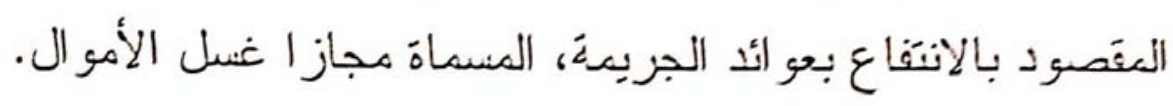

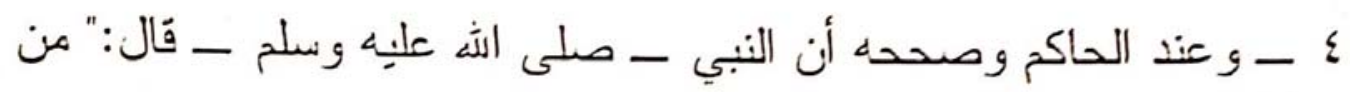

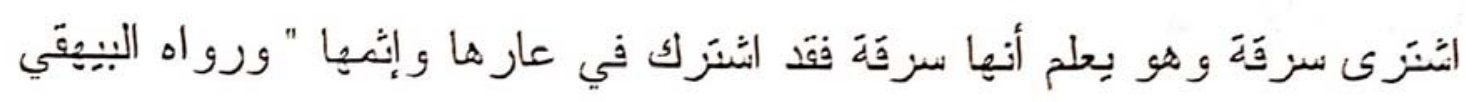

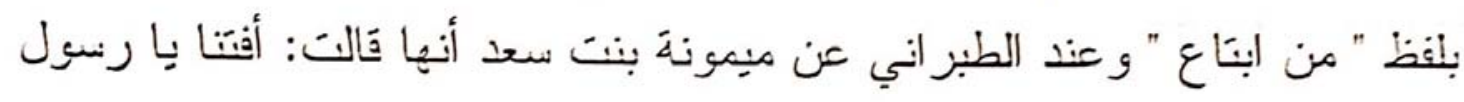

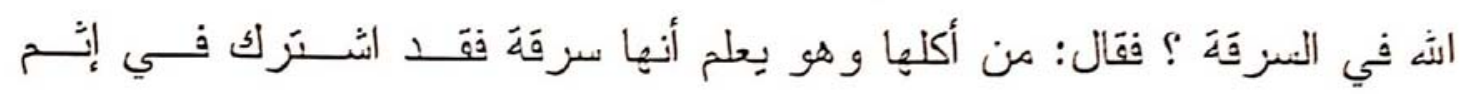

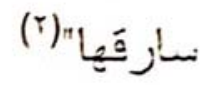

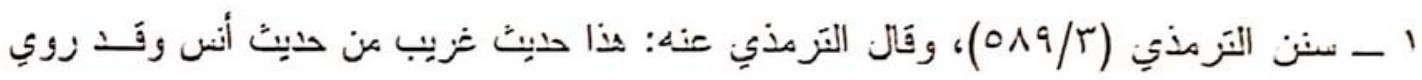

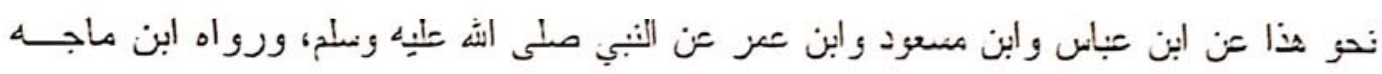

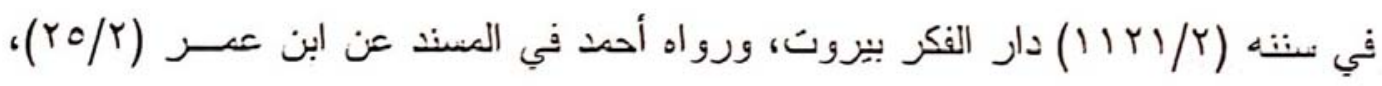

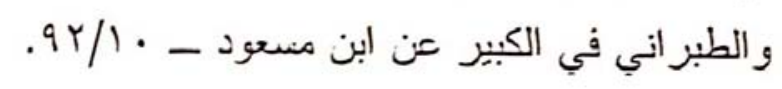

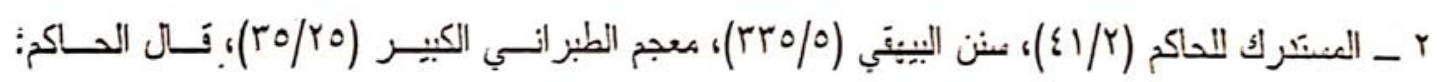

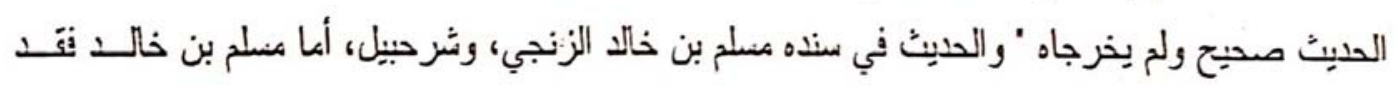

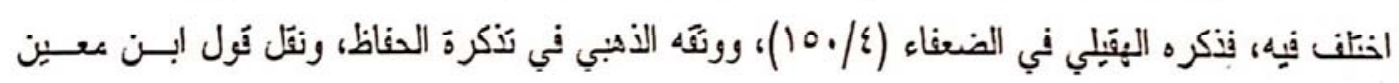

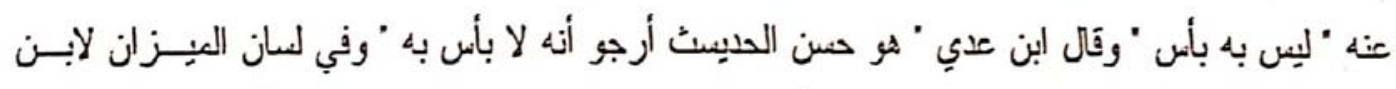

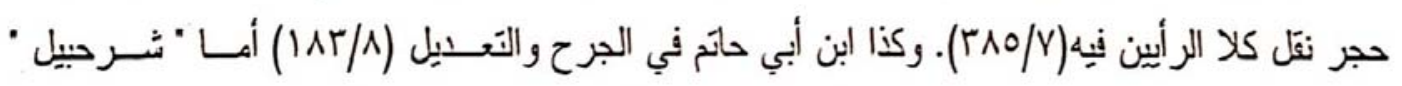

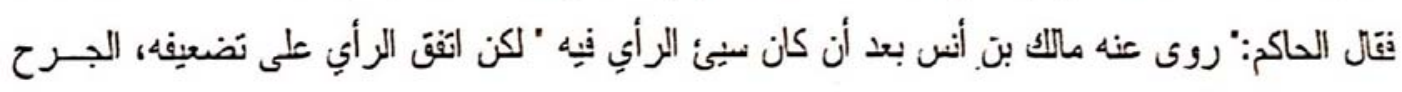
والتحديل: ؛ ؛

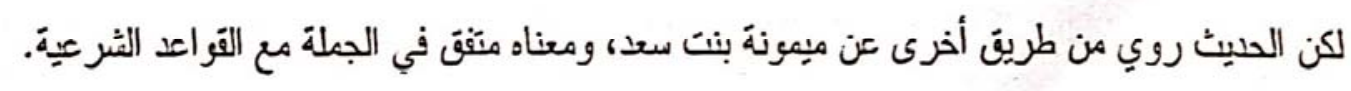


فقد بين الحديث أن من يتعامل مع السارق ويشُرَي منه المسسروقات أو يأكل منها فهو مثله في الإثّم و العار و المؤاخذة.

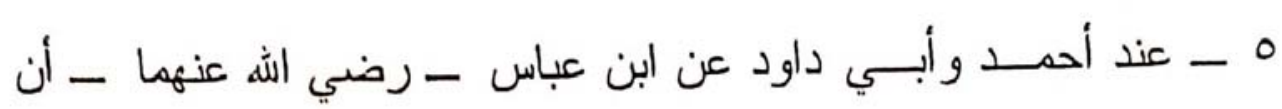

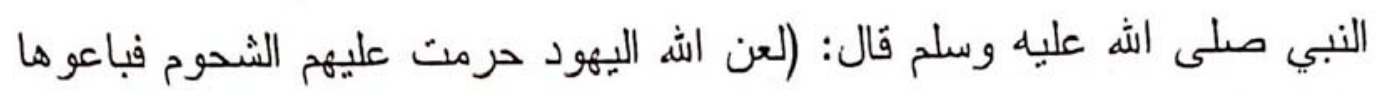
و أكلوا أثمانها، و إن اله إذا حرم على قوم أكل شيء حرم عليهم ثُنه) (") ففي الحديث تحريم للغة المال المحرم سو اء بالأكل أم بالتصرف فيه بـائي وجه من وجوه التصرفات

و هذه الأحاديث تكل على حظر الثعامل في الأمو ال المحرمة سواء بعقد من

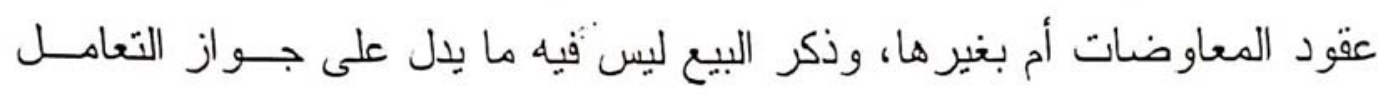

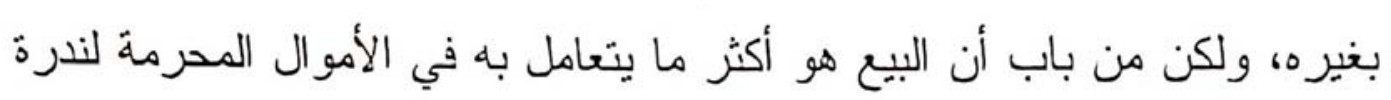
من يتصدق بالمال الحرام. ثانيا: أن تكون المنافع نفسها مباحة شرعا.

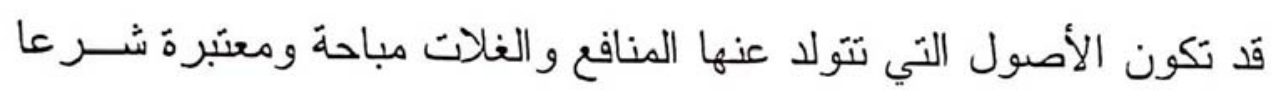

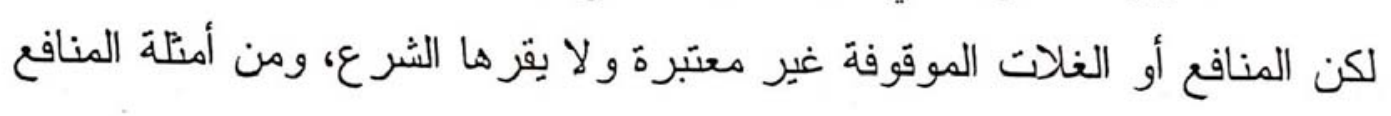
و الغلات المحظورة:

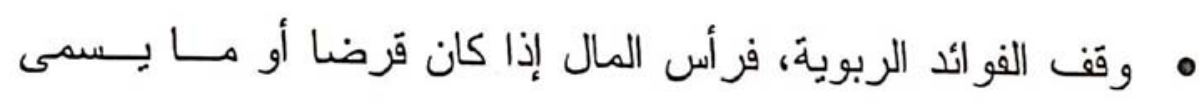

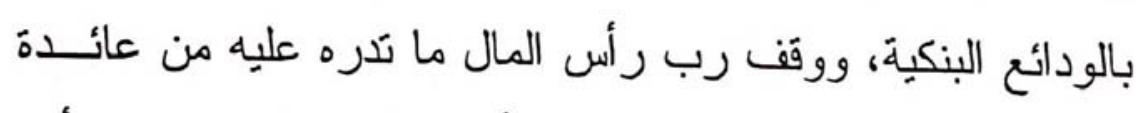

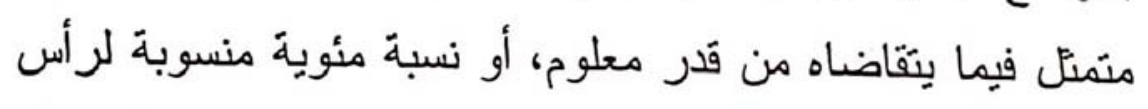

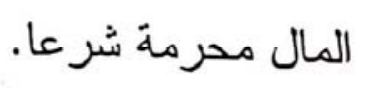
م وقف نقود لإقر اضها قرضا ربوياً.

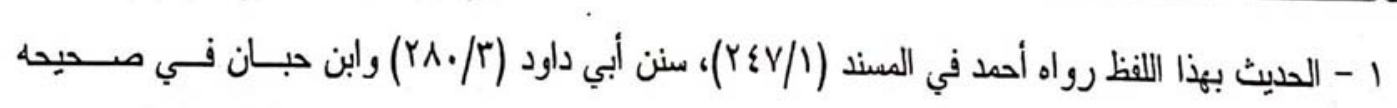

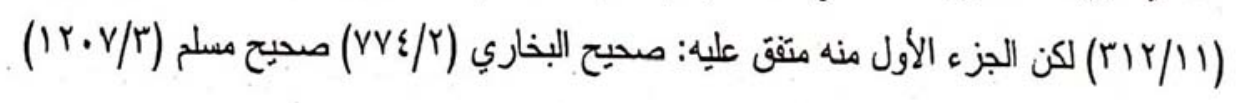


وقف منافع حبو انات لإقامة دسابقات علبهــا محنلــورة شـــر عا

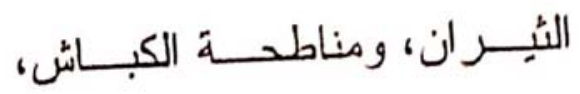

صار عة

الديكة.... - n

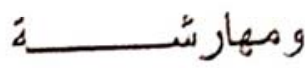

وقف الأعمال المحظورة شــر عا كالـسـر ، و أعمــال الزينــة

$$
\text { و التجمبل المحرمة، و الزنا، و الفو احش... }
$$

وقف كتب ومو اد إعلاميِة أو إعلانيــة تـدعو إلــى المنكـــــات

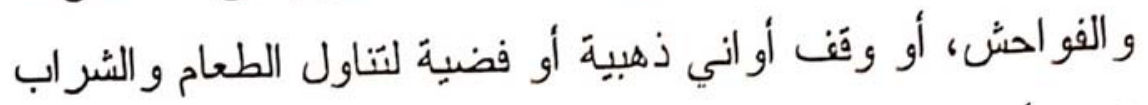

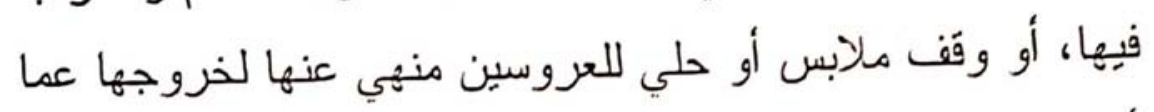

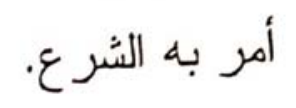

ما تقدم ونظائره من الغلات و المنافع المحظورة لا يجوز التعامـل عليهـــا

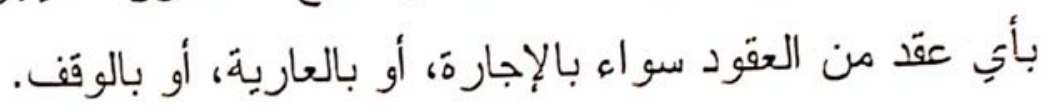
ثالثا: أن تكون المنافع مملوكة للواقف.

يجب أن تكون المنافع الموقوفة مملوكة للواقف، وليِ هذا بـشرط فـي المنافع فقط إنما هو شرط في وقف المال مطلقا، وهو أول شرط اعتنى به الفقهاء في شروط المال الموقوف. (')

لكن بحث ملكية الو اقف للمنافع برد عليه أمر ان: أحدهما: أن الشخص فَـــ يملك منفعة عين و لا بملك بلك العين. الثاني: أنه قَد بملك الانتفــاع بــالعين و لا بملك المنفحة، ونبين حكمهما فيما يلي:المسألة الأولى: مدى جواز وقف المنفحة من غير مالك عينها.

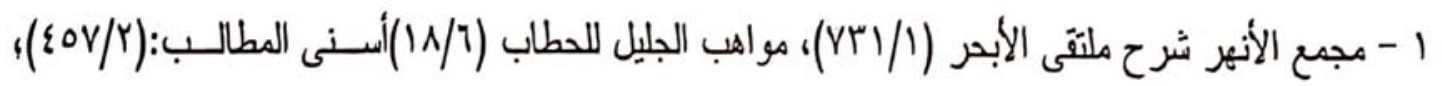

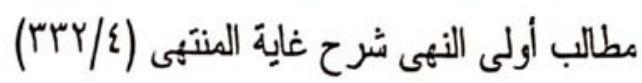




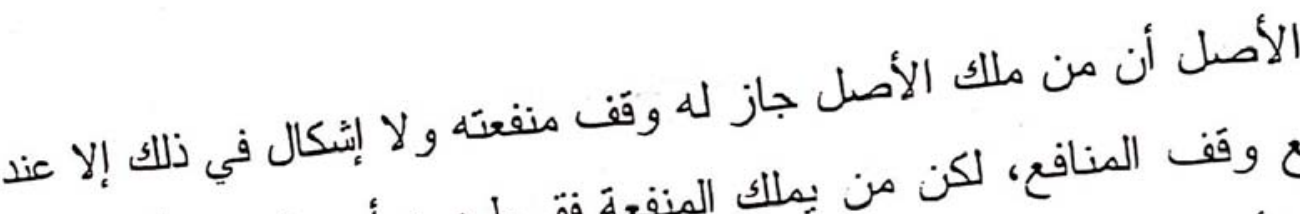

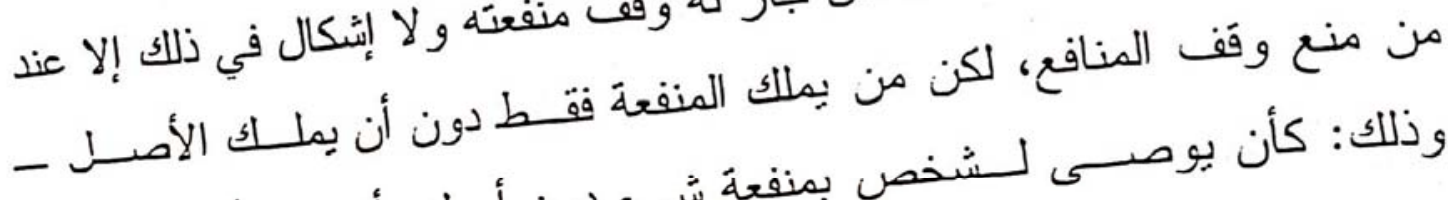

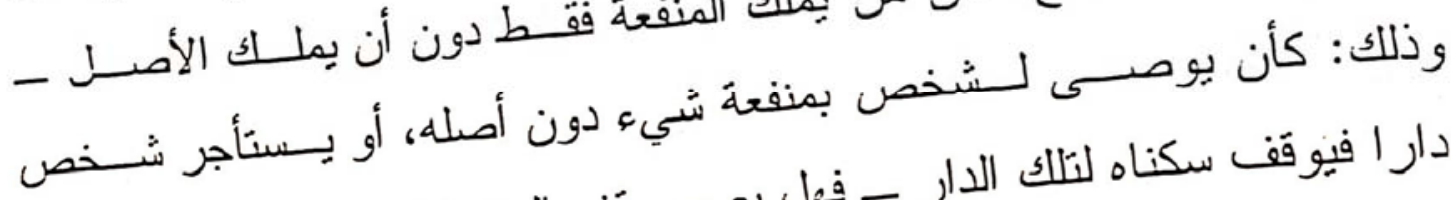

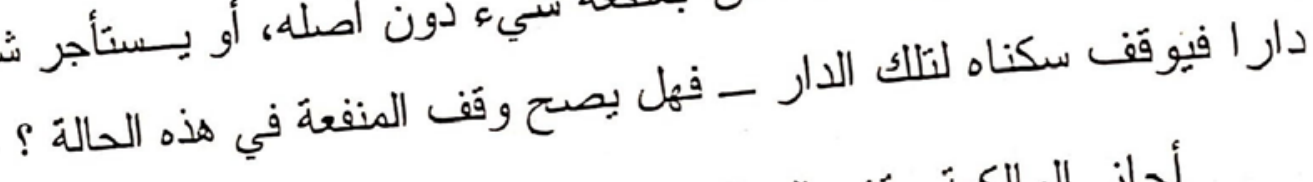
أجاز المالكية وقف المنافع مطلقا سواء أكان الواقف يملك الأصــل أم لا لأل

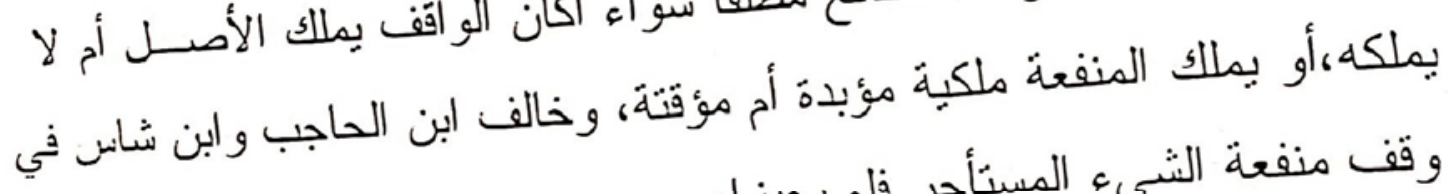
وقف منفعة الثيء المستأجر فلم بجيز اه.

قال الخرشي: " و أشار المؤلف بقوله (و إن بأجرة) إلى صحة وقف المنفحة لمن لا يملك الذات أي: و إن كان الملك بأجرة، و أسند الملك للأات لملك منافعهيا،

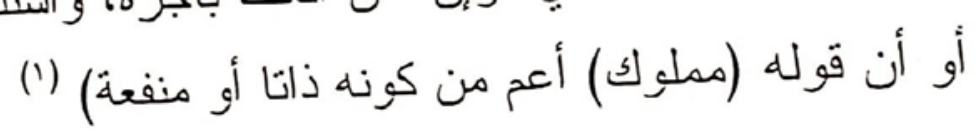

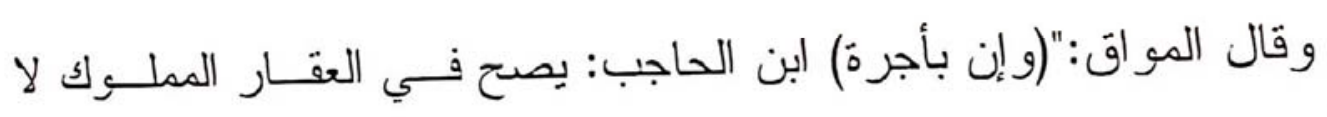

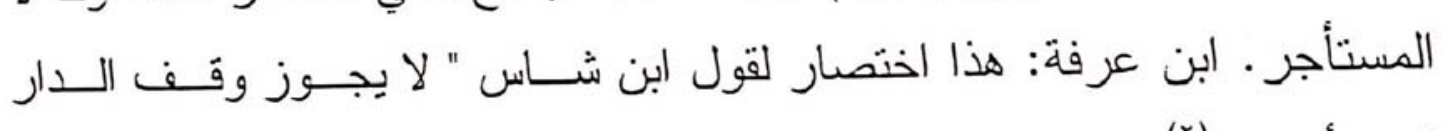

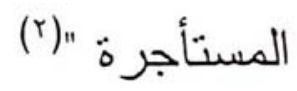

وقد استثى المالكية من جواز وقف المنفحة لمن لا يملك الأصـلـل وةَّف المنفعة الموقوفة فلا يجوز وقفها، قال الخرشي:" هذا ما لم نكن منفهـة حـبس؛

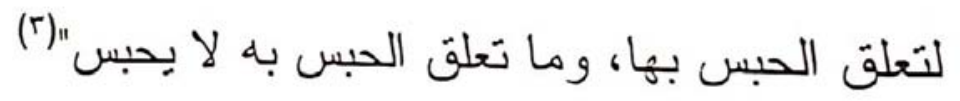
وما ذهب إليه المالكية من جواز وقف المنفعة سواء أكان الأصل مملوكتـا.

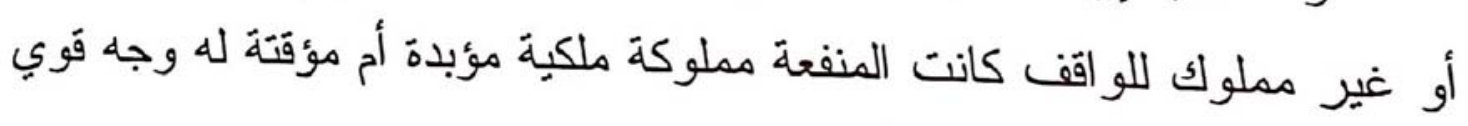

1 - شرح الخرشبي لمختصر خليل (Y9/V) r - التاج والإكليل لمختصر خليل (Tr/Y r - شرح الخرشي: موضع سابق. وير اجع: حاشية الدسوقي (ع/VY. 
من الصحة يفيده الأدلة العامة القاضية بالحث على التبرع و الإحسان، وغير ذلك مما عرضناه في جواز ودَّن المنافع.

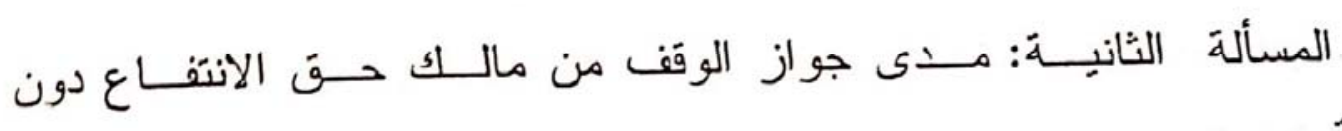
المنفعة. يختلف تمليك المنفحة عن نَمليك الانتفاع في أن تمليك الانتخــاع: يخــول صاحبه مباشرة هذا الحق بنفنه نقط دون أن يتصرف فيه لغيره، وذلــك مثــل

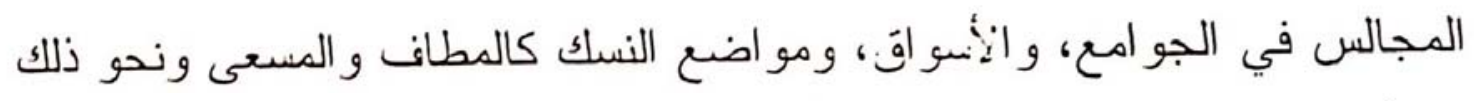

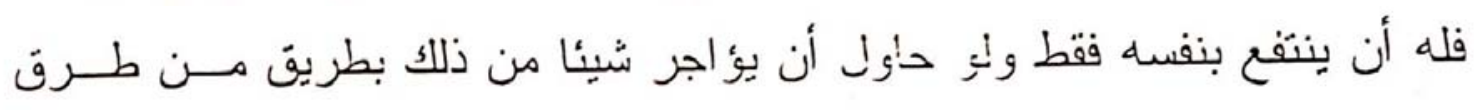
المعاو ضنات امتتع ذلك.

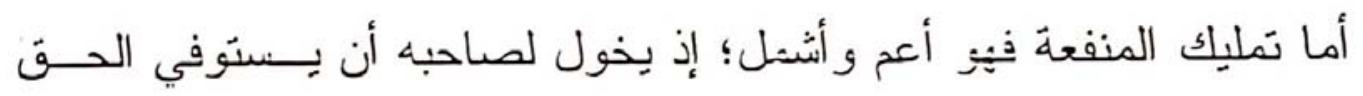
بنفسه ويمكن غيره أيضا من ذلك، وذلك كمن استأجر دار أو استعارها فلـــه أن أن يؤ اجر ها من غيره أو بِيكذه بخيز عوض ويِصرف في هذه المنفحسة تـصرف الملاك في أملاكهم على جزي العادة على الوجه الذي ملكه فيو تمليك مطلق في

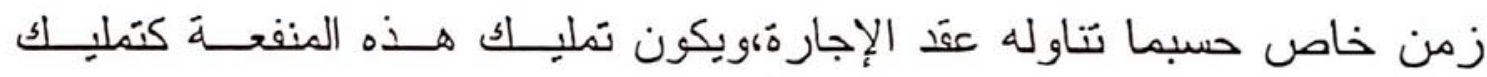

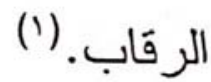

و هنا لكي يجوز ودَف المنافع يجب أن يكون الواقف مالكا للمنفعة لا مالكا لحق الانثفاع بها فقط. رابعا: إمكان استيفاء المنفعة. يجب أن يمكن الموقوف عليه من استيفاء المنفحة الموقوفة له، ولا يمنــع من ذلك أي مانع؛ وذللك حَى ينَحقق الغرض من الوقَف. 
و لإمكان استِفاء المنفعة يجب أن تكون المنفعة و أصــــها معـــومين، وألا

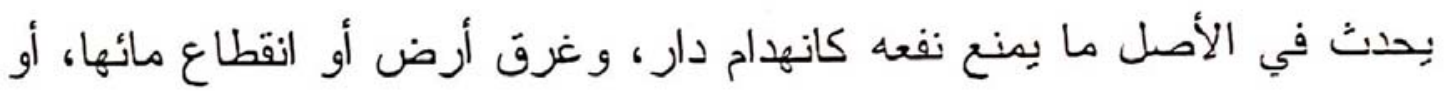

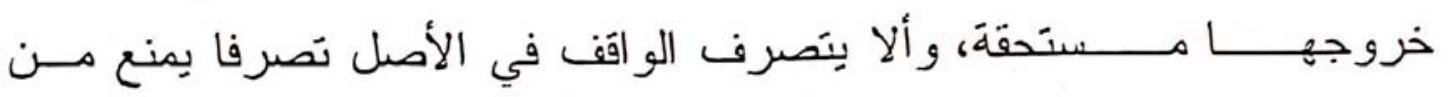
كمال تحصبل المنفعة. 


\section{المبحث الرابع}

\section{الوقف المؤقت للمنافع}

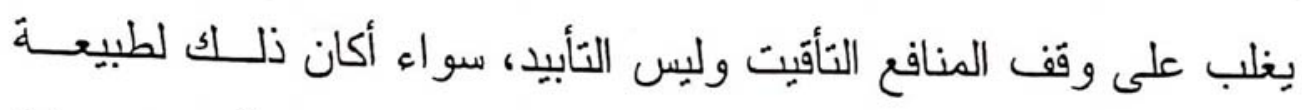
المنفعة نفسها وكونها مؤقتَة كمنافع الأشخاص من عمل ونحوه، أو لاشــتر اط ولط الو اقف ذلك، أو لطبيعة الموقوف عليه وكونه مصرفا غير دائم، ومسـن صــور وقف المنافع الغالبة في الحياة العملية: أن يرغب شخص في وقف منفعة سيارته،

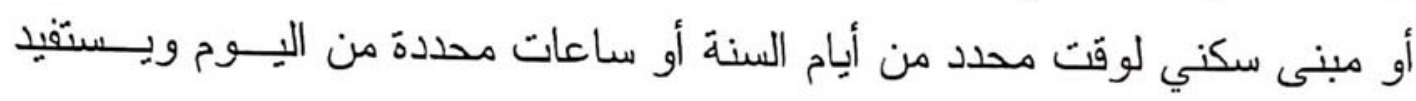
بماله بعد ذلك، كما يحدث أن يخصص طبيب أو مهندس ونحو هما عـددا مــن الساعات أو الأيام لصالح مؤسسة خيرية أو لأهل بلده و لا بحبس نفسه لذاب لذلك أبدا، فهل يصتح الوقف في هذه الحالة مع أنه غير مؤبد ؟ اختلف الفقهاء في تأقيت الوقف على ثلاثة أقوال:

الأول: لا يصح الوقف مؤقَّا، وهو قول الحنفية، ومشهور مذهب الشافعية، و المذهب عند الحنابلة.

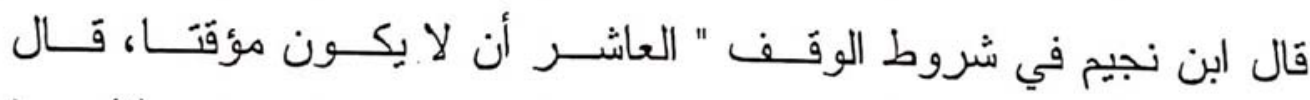
الخصاف ('): لو وقف داره يوما أو شهر ال ال يجوز لأنه لم يجعله مؤبدا " (r) وقال

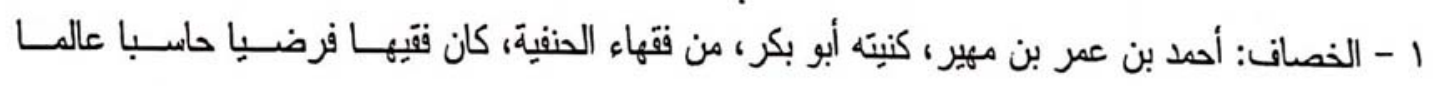

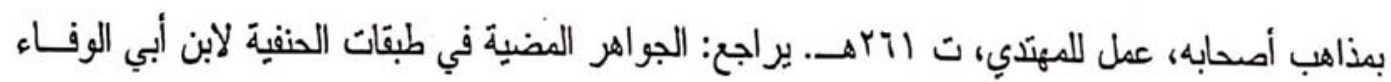

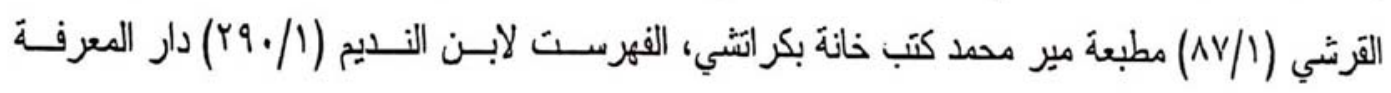


المرداوي " وإن قال: وقنته سذة: لم يصح، هذا الذذب " (") وفي المنهاج " ولو

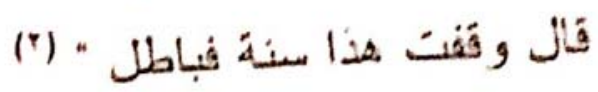

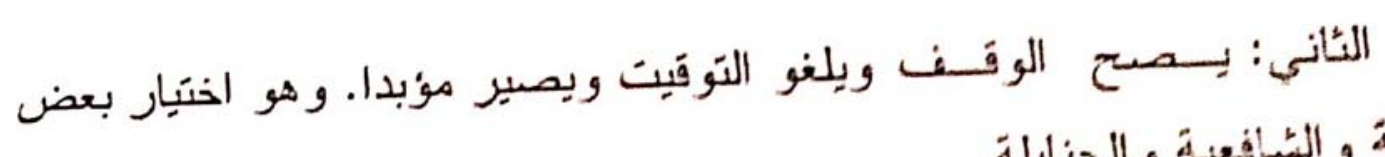

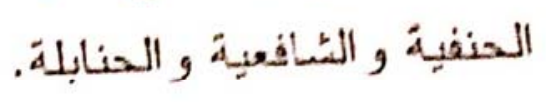

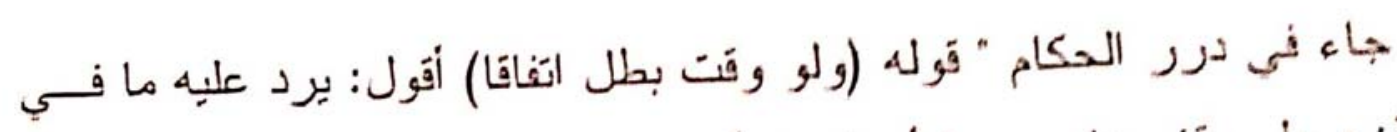

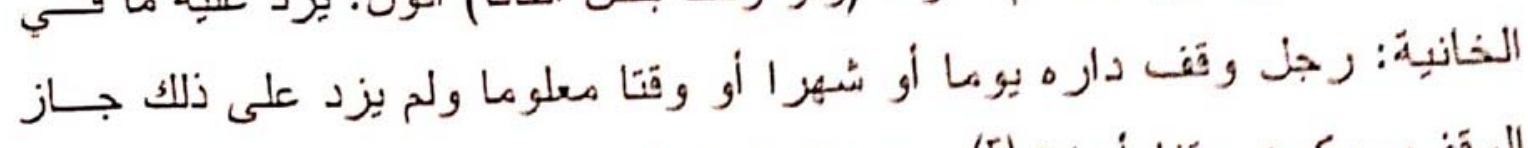

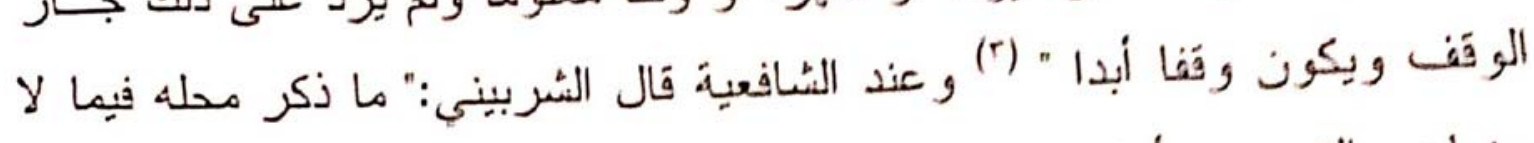

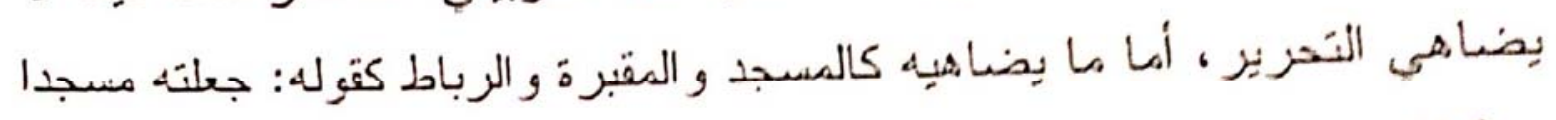

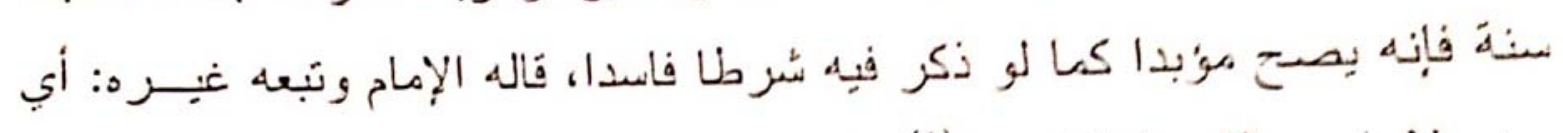

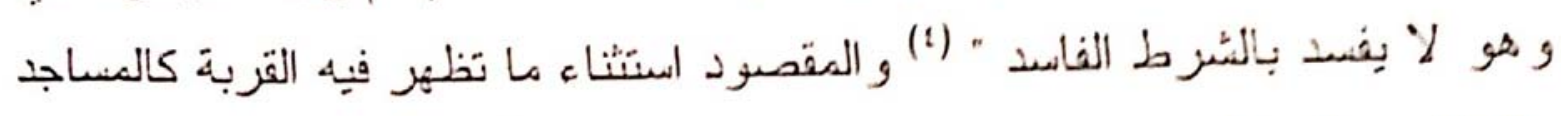

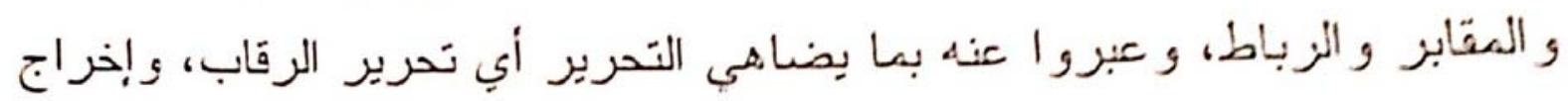

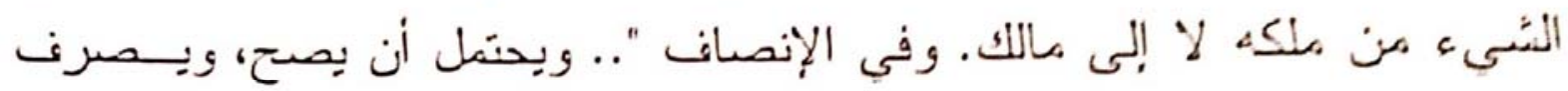

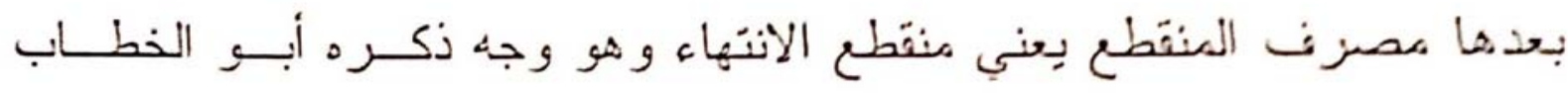

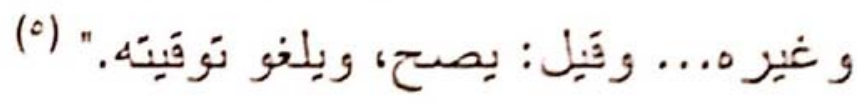

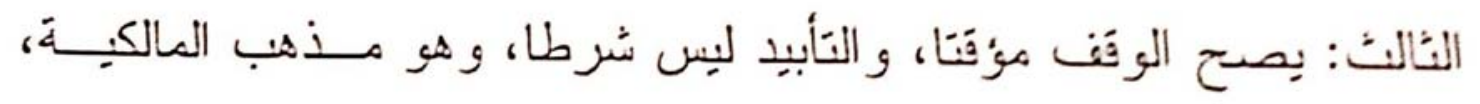

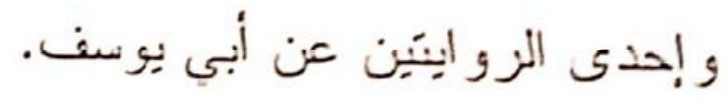

$$
\begin{aligned}
& \text { 1 - الأتصات (ro/v) } \\
& \text { roro/r) - بفنى النقتاج }
\end{aligned}
$$

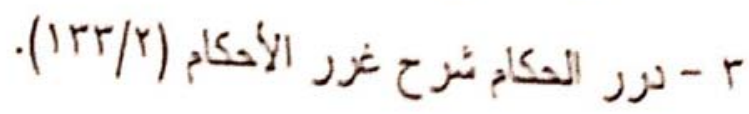

$$
\begin{aligned}
& \text { ؛ - مغني المتّاج (oro/r) } \\
& \text { - الأتصات - مرجم سابق. }
\end{aligned}
$$


جاء في الثُرح الصغير " ولا يُشَرط فيه التأبيد: بل يجوز وقفه سـنة أو

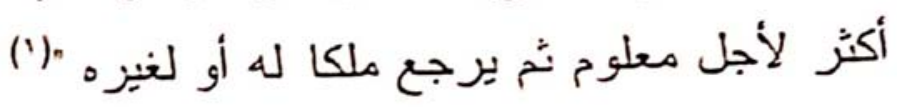

وفي شرح النبر الكبير:" المذهب عند محمد رحمه اله تعالى أن التأبيــ

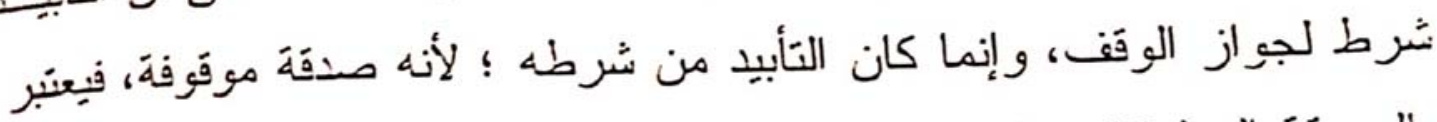

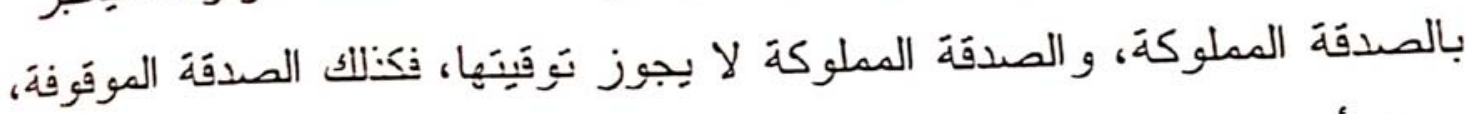

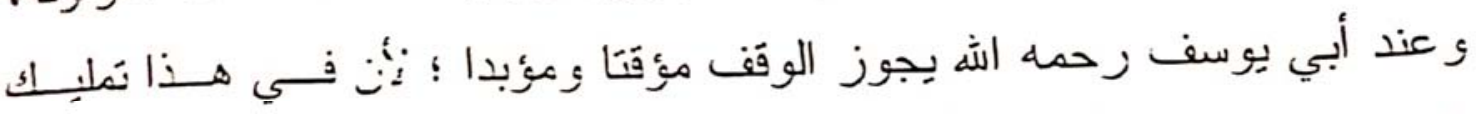

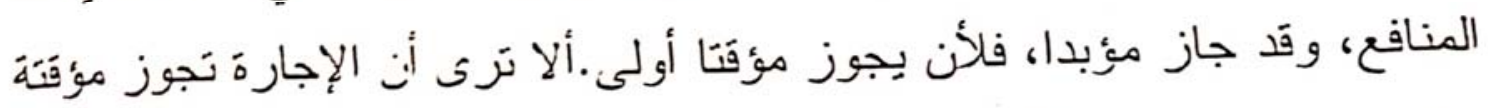

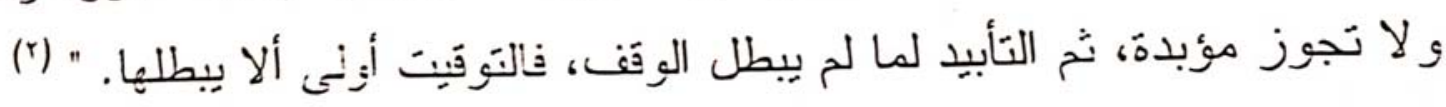

$$
\begin{aligned}
& \text { 1 - حانشية الصاوي على الثرح الصنير (؛/. 1. } \\
& \text { r شرح السبر الكيبر (rIIN/0 }
\end{aligned}
$$

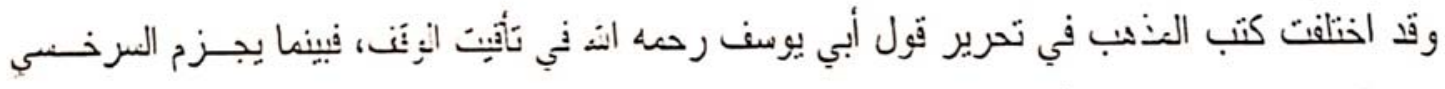

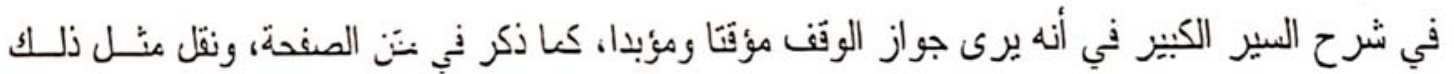

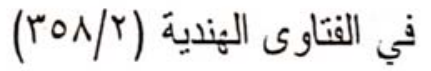

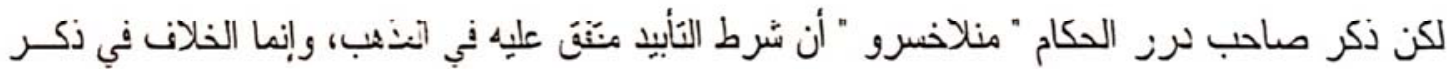

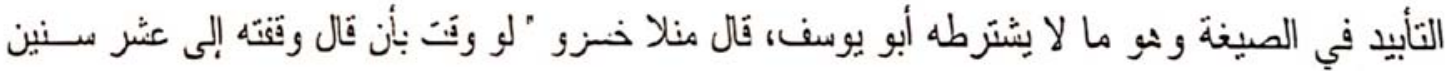

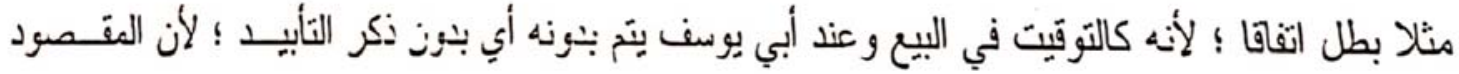

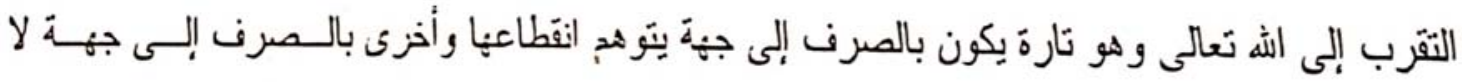

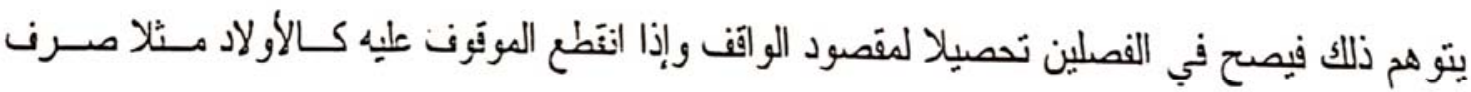

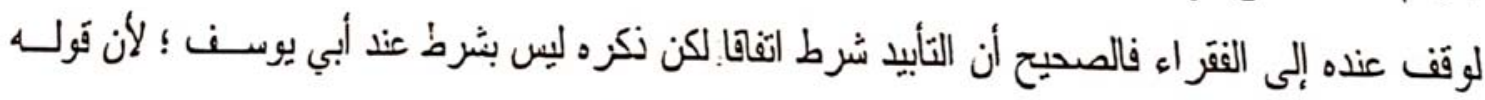

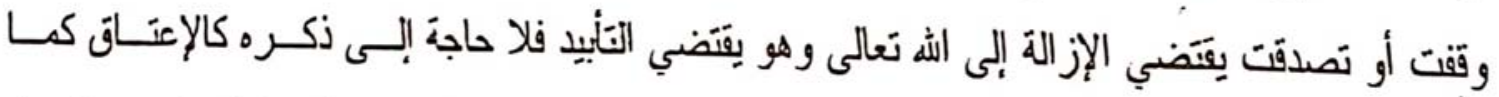

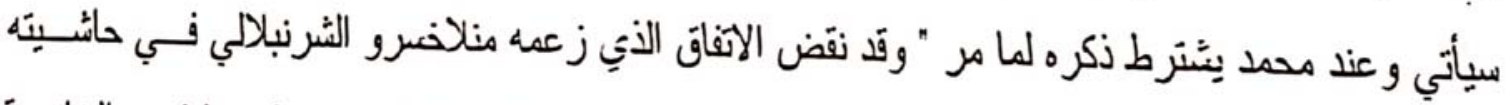

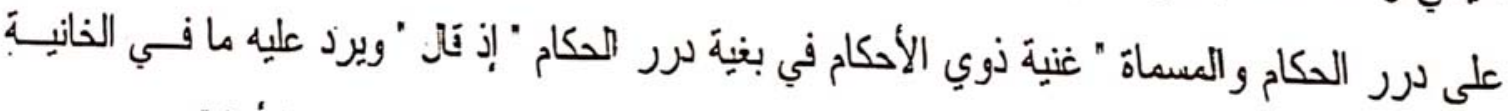

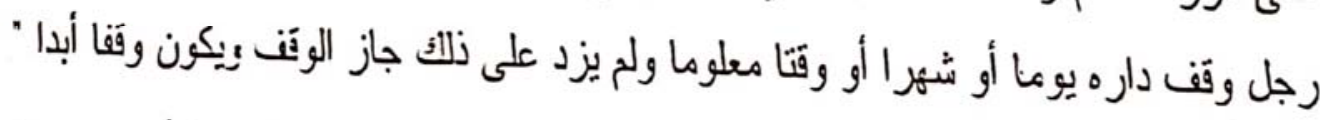
وقد حرر ابن عابيدين مسألة تأبيد الوقف في المذهب في مطلبين فقال: مطلب: التأبيد معنى شــرطه اتفاهـا،

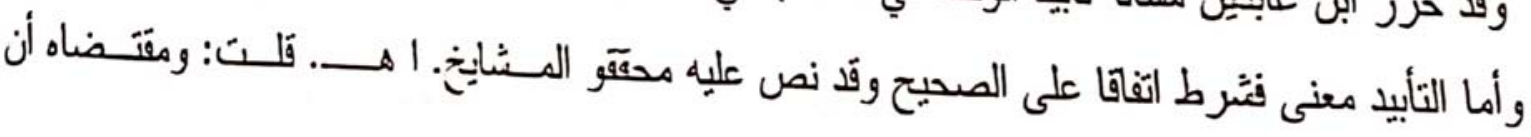


أو لا: الوقف إز الة الملك لا إلى أحد فلا بحثمل الثوقيت كالإعناق وجعل

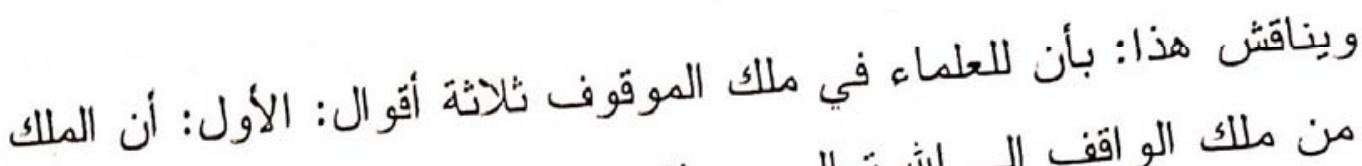

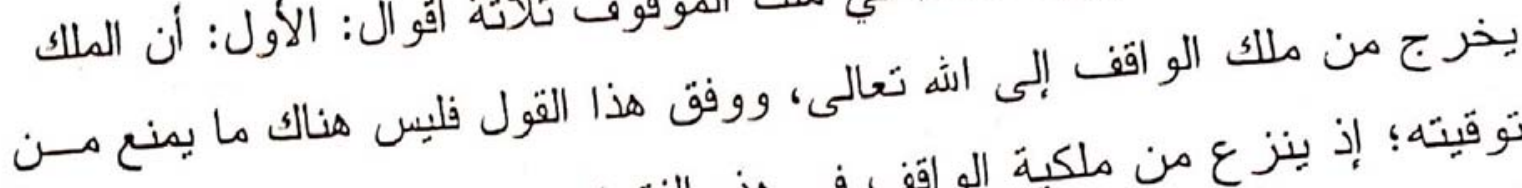

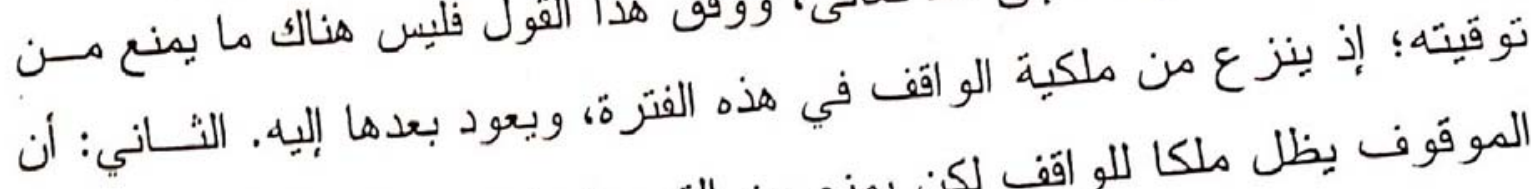

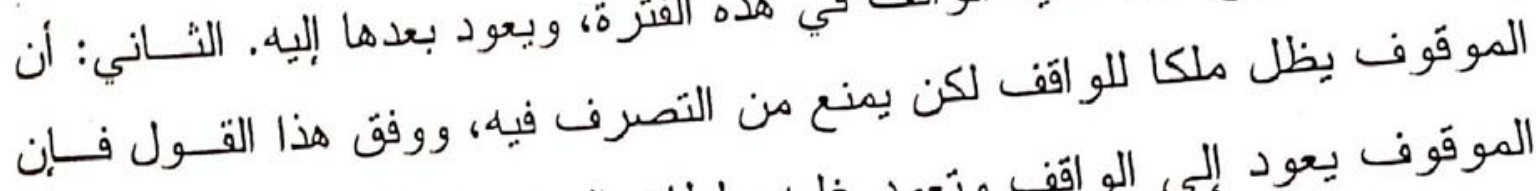

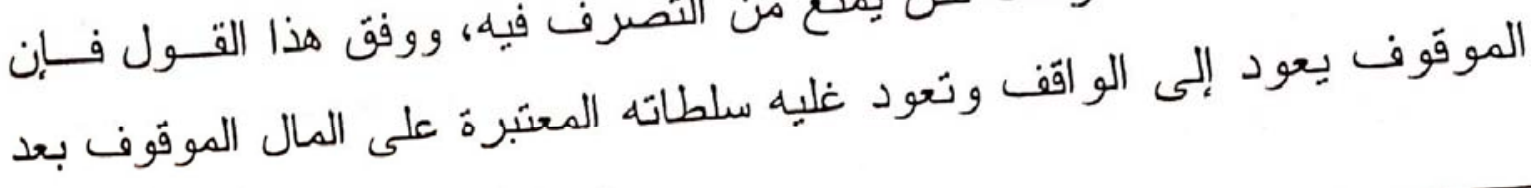

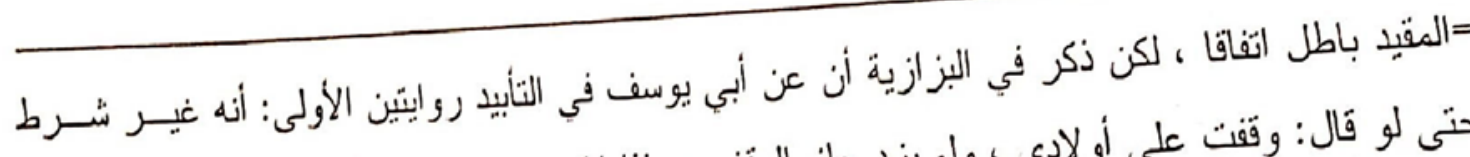

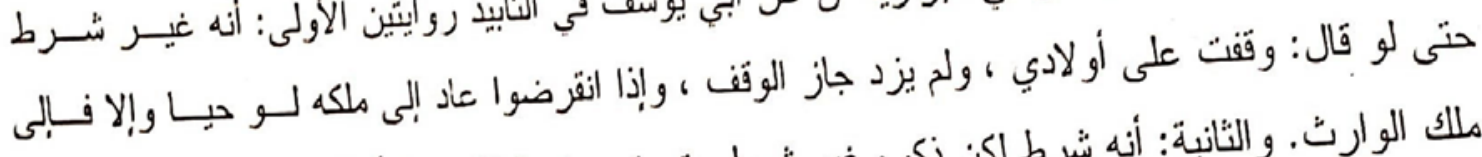

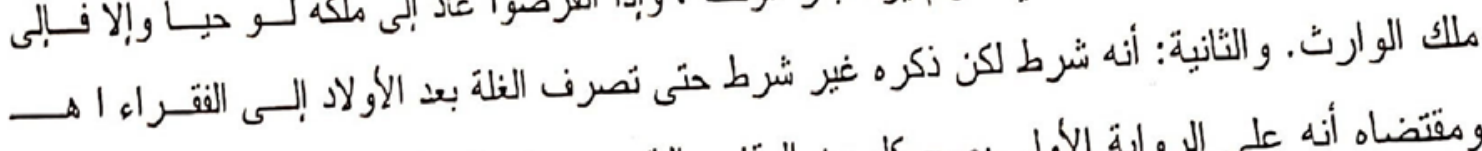

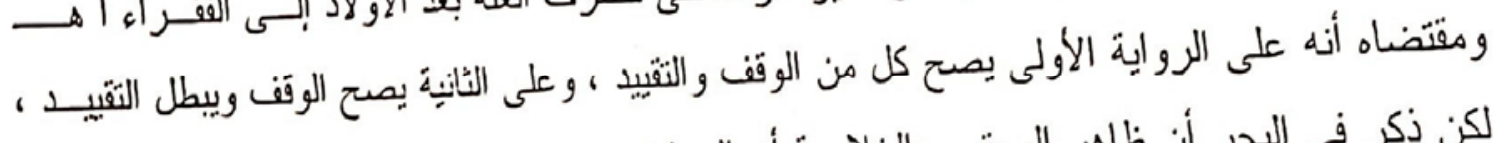

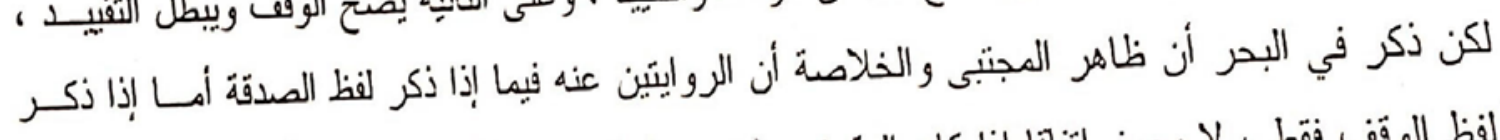

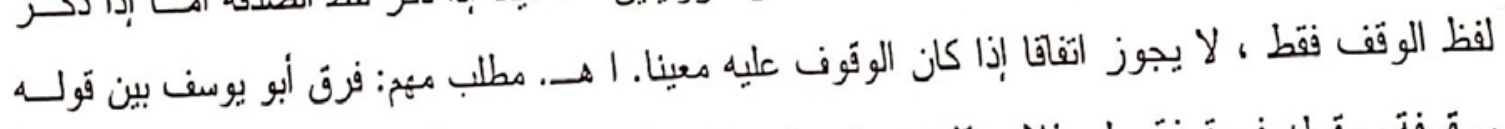

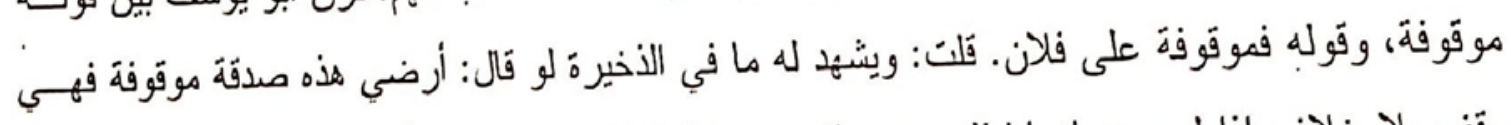

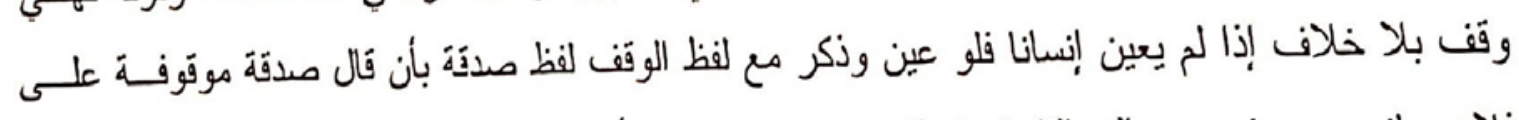

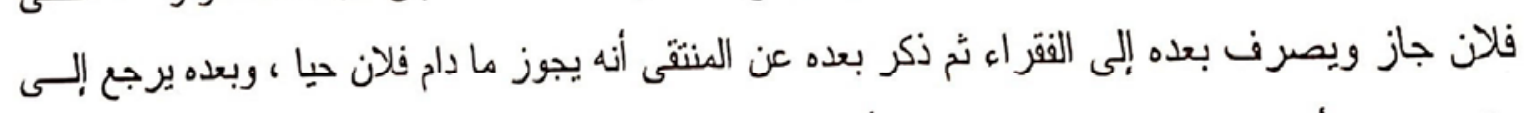

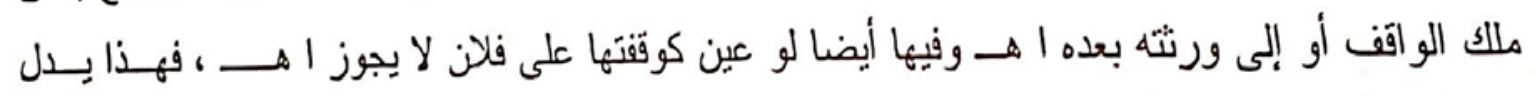

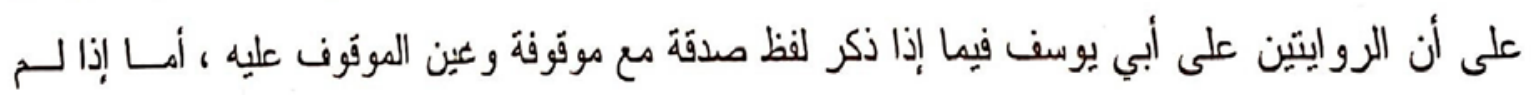

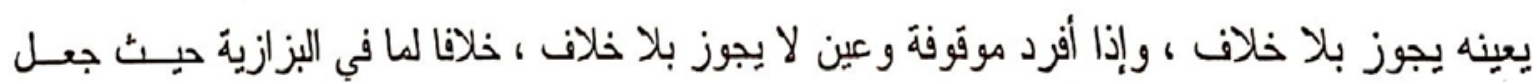
الرو ايتيتن فيه ، فإنه يقتضي صحة الوقَ ، ويخالفه أيضا كلام الإسعانف وتَوله في الهداية: وقيلل إن التأبيـد

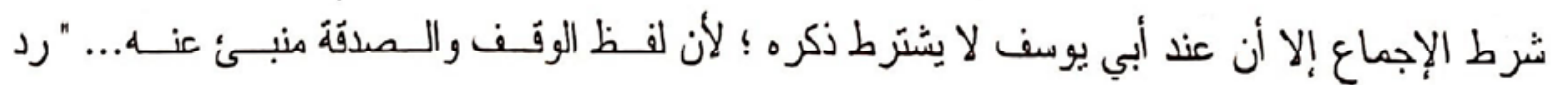

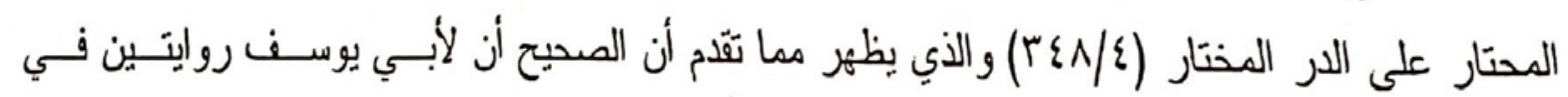
المسألة.

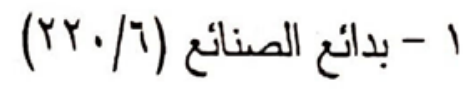




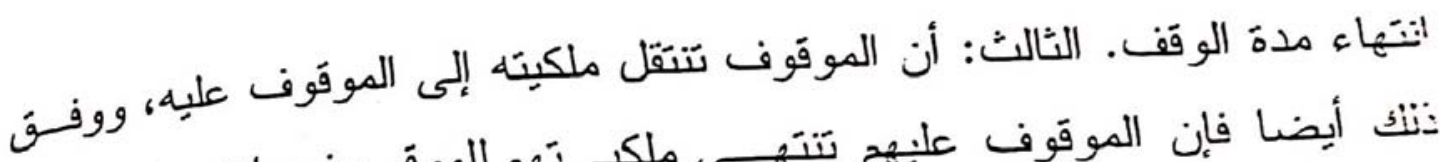

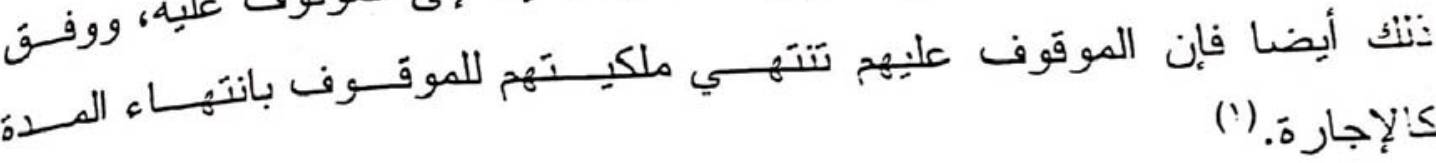
ثَانيا: مفتضى الوقف التأبيد، و اشتَر اط التأقيتَ ينافيه ويخالف مقـصوده

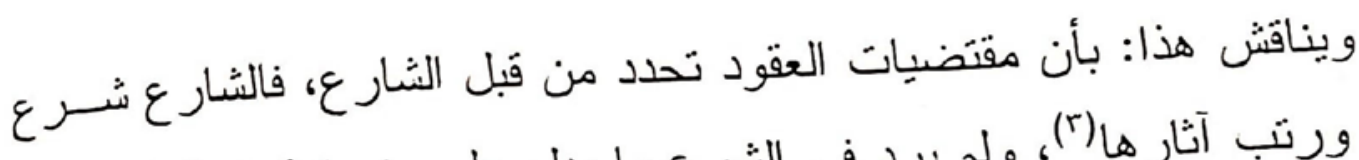

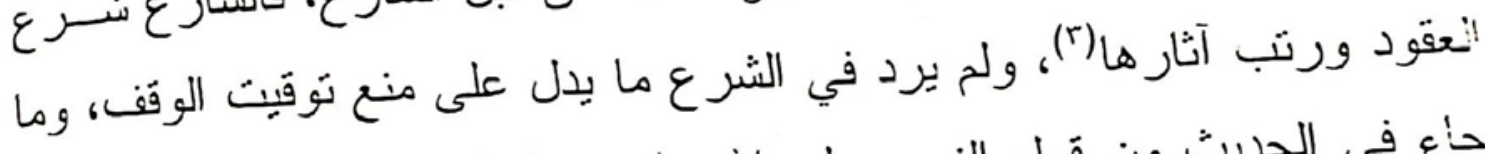

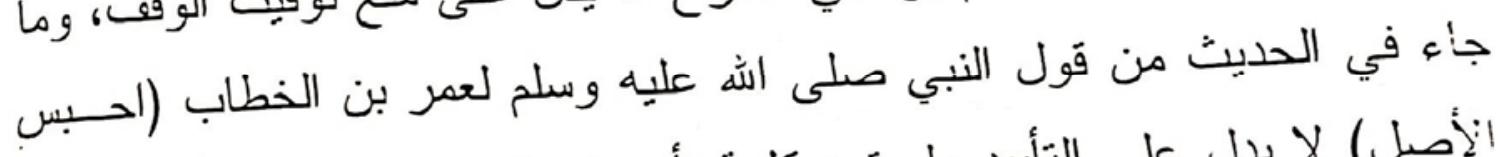

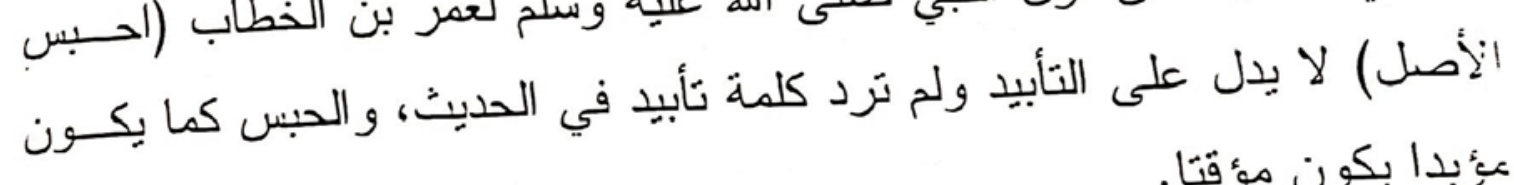
مئبدا يكون مؤقتا.

و الأولى أن يقال: إن الوقف من عقود التبّرعات والإحسان التي ينسشّف

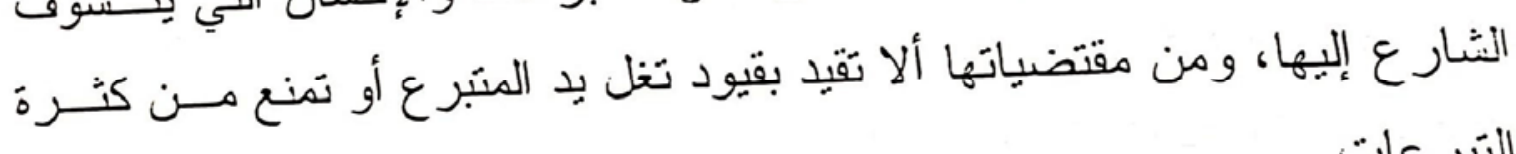
التبرِر عات.

ثالثا: القياس على عقود التبرعات الناقلة للملكية كالهبة ونحوها حيــث لا نصح نوقيتها فكذا الوقف. (؛)

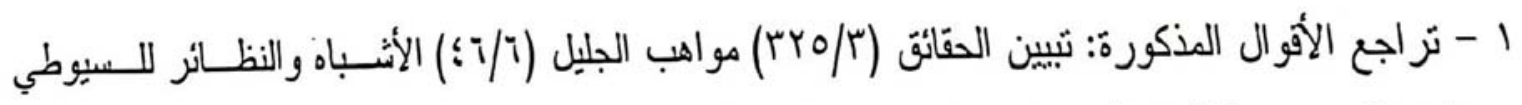
:

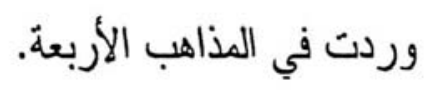

r - حاثية قليوبي و عميرة على شرح جلال الدين الدين المحلي للمنهاج (r/ . 1 )

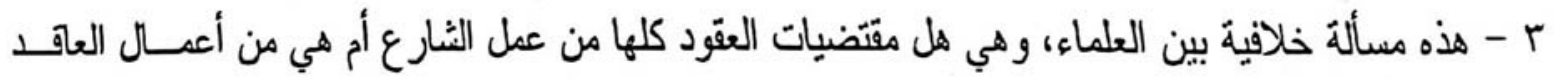

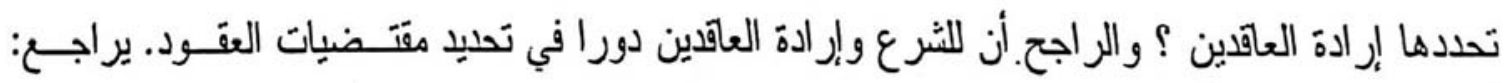
الملكية ونظرية العقد اللشيخ أبو زهرة (rrq) ؛ - الغرر البهية شرح البهجة الوردية (r/rr/r) 
ويناقَش هذا: بأن الوقَف لم لا يِاس على العقود الواردة على المنافع التي

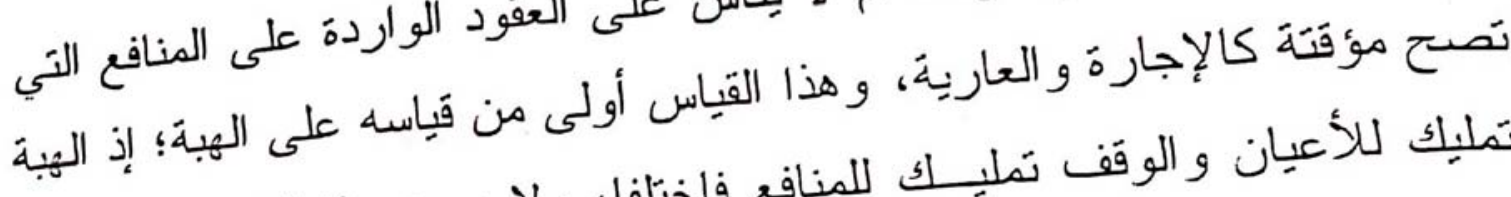

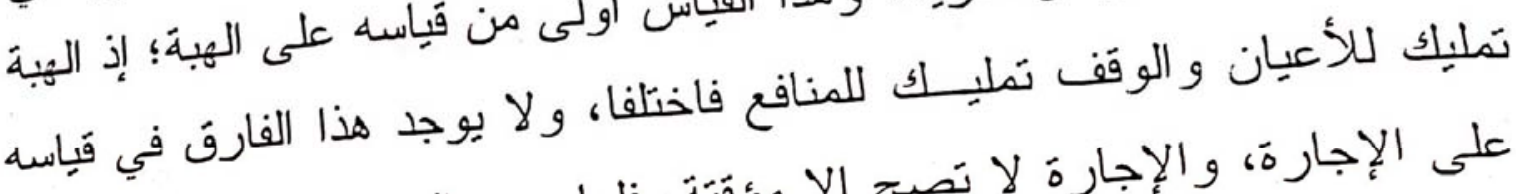

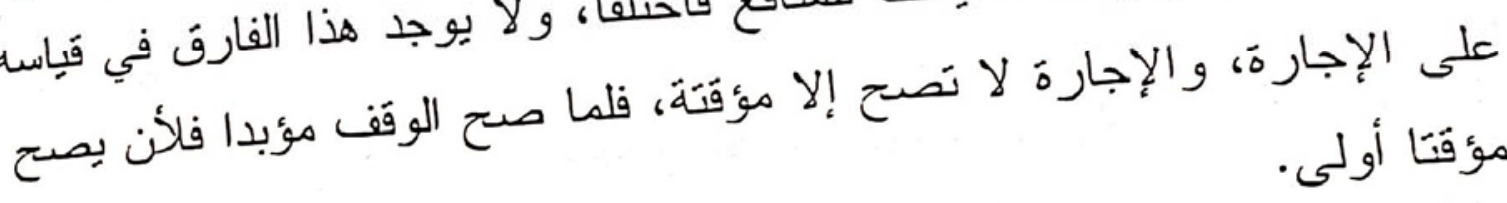

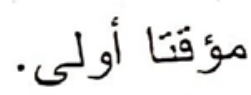

وجه القول بصحة الوقف وبطلان شرط التوقيت:

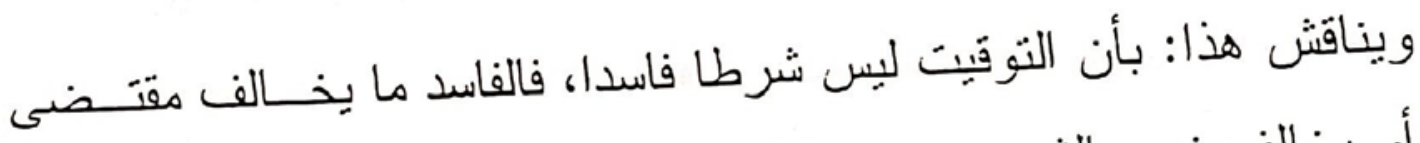

أن التوفيت كالشرط الفاسد فيلغو ويصح العقد. (1) العقد، أو يخالف نص الشرع، وهو ما لم يشبت. وجه القول بصحة الوقَف مؤقَّا ومؤبدا:

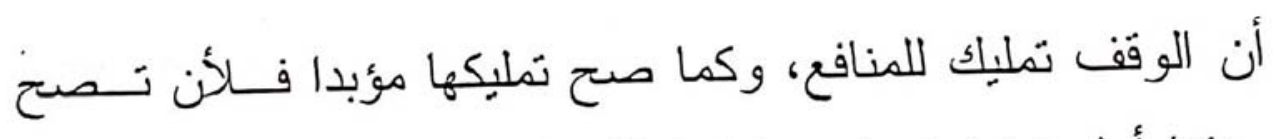
مؤقتا أولى؛ فَياسا على تمليكها بالإجارة، وقَّ صحت توقَبت تمليك المنفعة بعوض فلأن نصح مؤقتا بدون عوض أولى.

• أن الوقف من عقدد الإحسان و التبرع، وليس على المحسنين من سبيل فيجوز أن يوقف مؤبدا أو مؤقتا وفي جميع الأحوال سيتحقق مقصود الوقف.

و هذا القول الأخير هو ما بظهر رجحانه خاصة؛ لعدم وجود ما بدل نعلى التأبيد من نص شرعي، أو قياس صحيح أو إجماع معتبر · مُول

انتهى. البحث، و لله الحمد و المنة، ومنه العون والتوفيق، و عليه توكلت و إليه 


\section{خاتـــة}

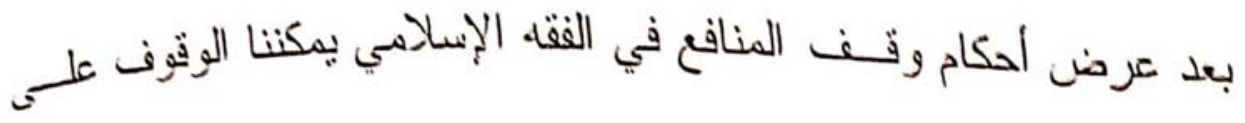

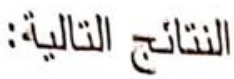

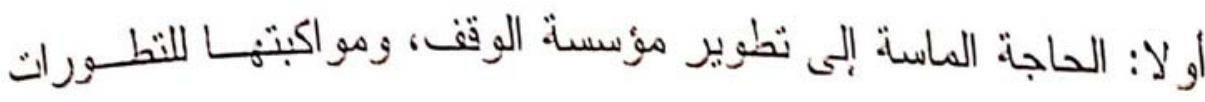

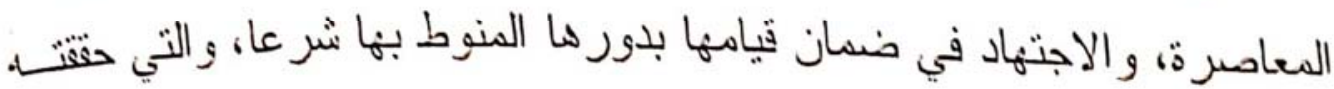
على مدار ثاريخ الأماة الإسلادية.

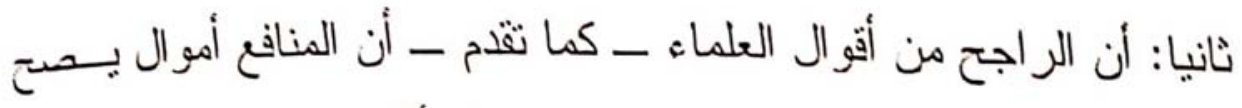

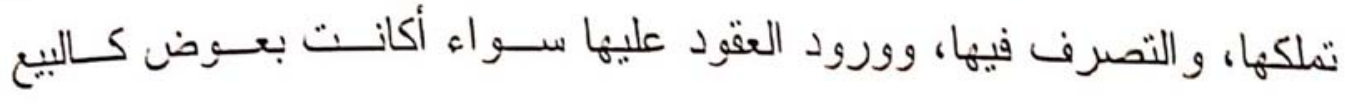
و الإجارة أم بغير عوض كالوقن والعارية.

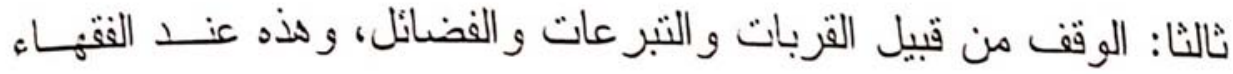

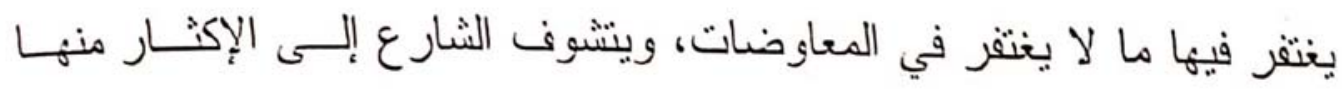
وترغيب الناس فيها.

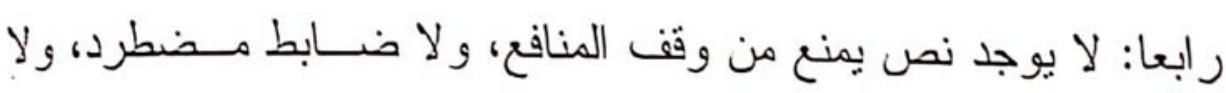

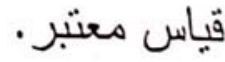

خامسا: للعرف دور في تحديد ما يجوز وقفه وما لا يجوز، وهه ما ظهر

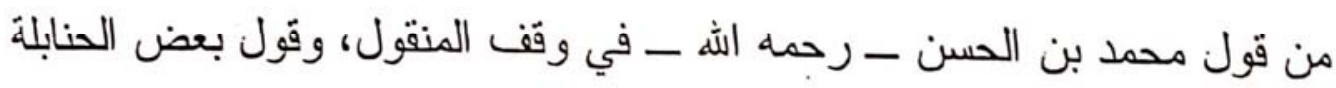
في وقف الماء.

سادسا: لجواز وقف المنافع بالإضافة إلى الشروط العامة للوقف ضوابط، منها: 1. أن تكون المنافع من أصول مباحة شر عا.

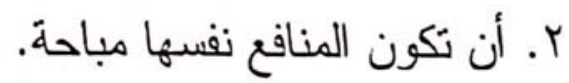




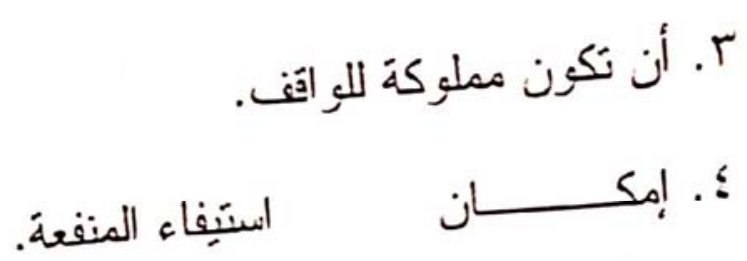

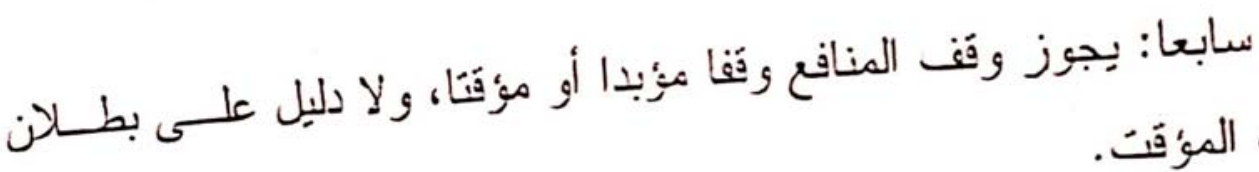

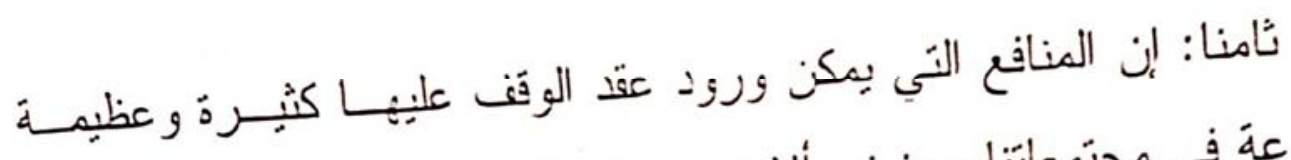

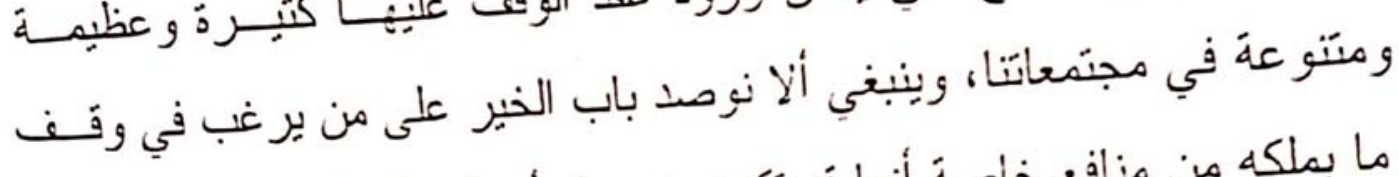

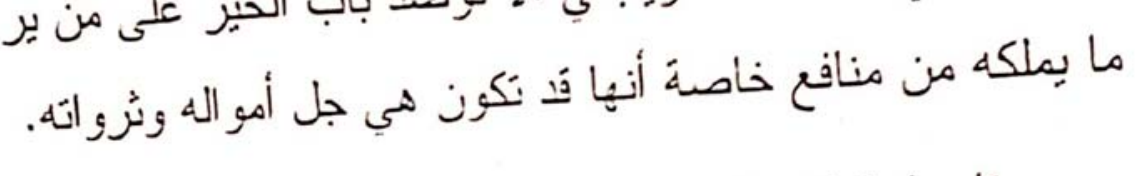

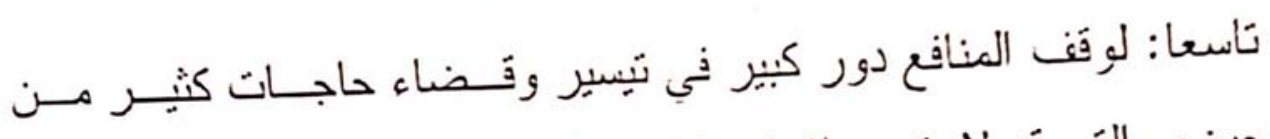

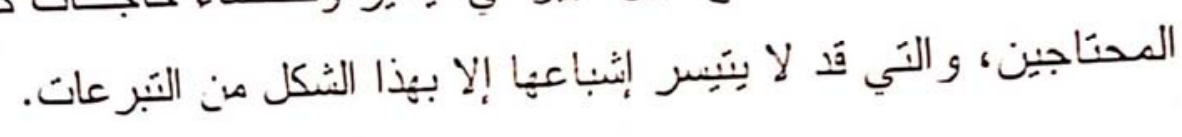

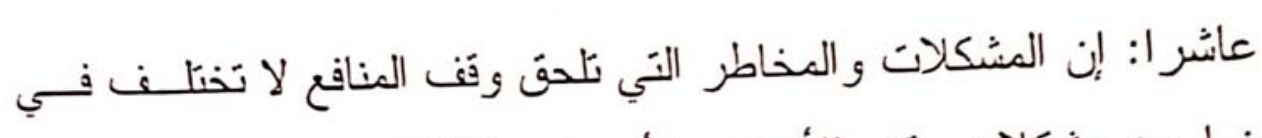

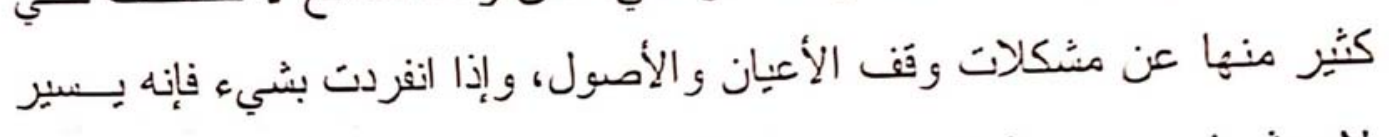

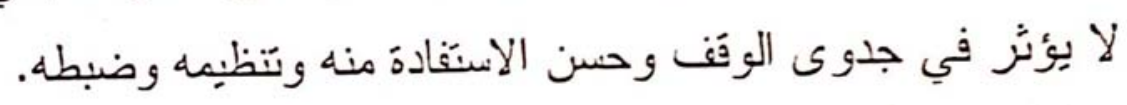




\section{المراجع}

ثبت بأهم المراجع مرتبة أبجديا بدون " أل" مع التصنيف الموضوعي

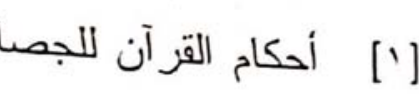

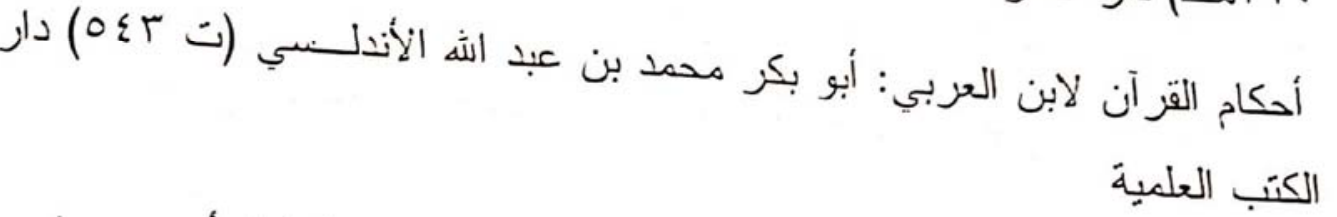

جامع البيان عن تأويل آي القز آن المعروف بتفسبر الطبزي للإمام أبــي جعفــر

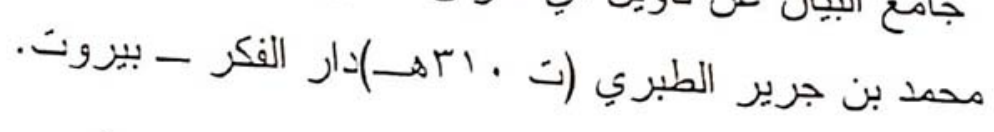

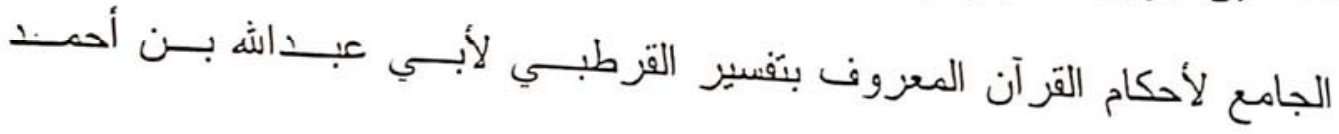

$$
\text { القرطبي(ت الخآ) دار الشعب. }
$$

ثانيا: الحديث الشريف وعلومه:

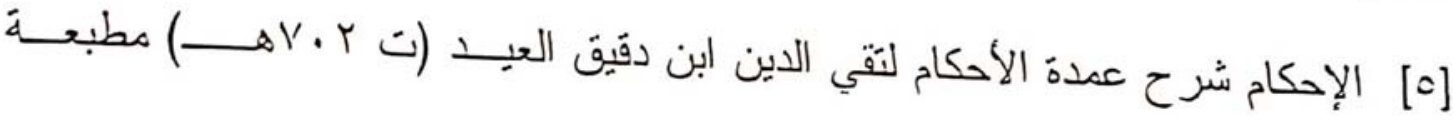

السنة المحمديةً.

[i"] تلخيص الحبير في تخريج أحاديث الر افحي الكبير للحافظ شهاب الدين أحمد بـن

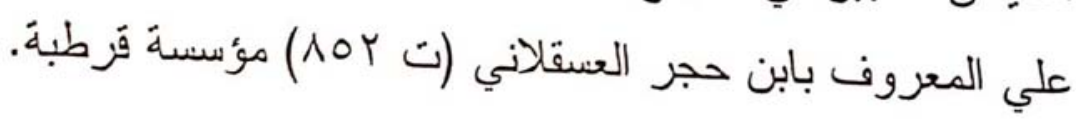

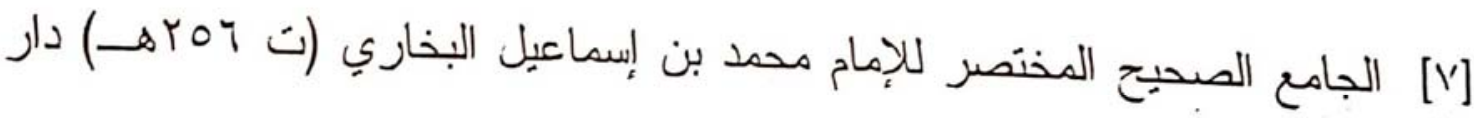

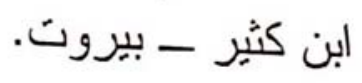

[^] سبل السلام شرح بلوغ المرام لمحمد بن إسماعيل بن صلاح الأمبر الكحلاني ثم

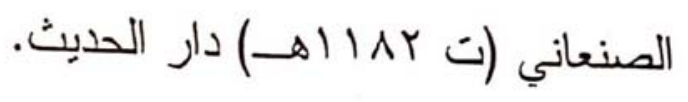

[9] سنن ابن ماجه للإمام ابن ماجه (ت rVo ســ) دار الفكر .

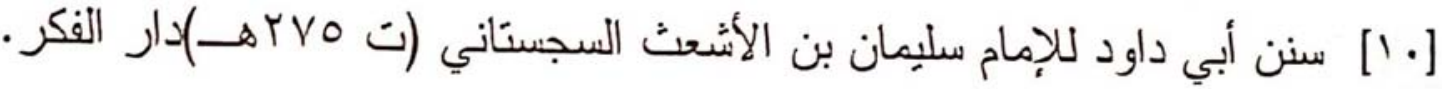




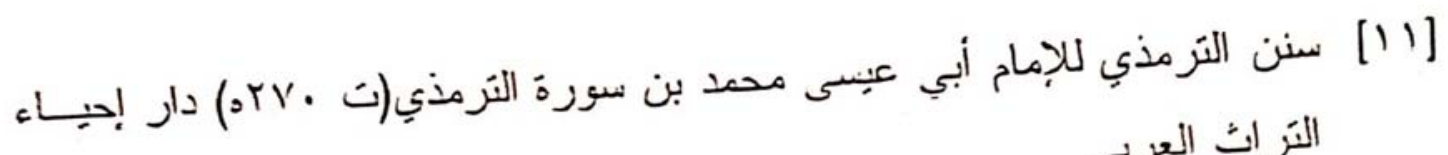

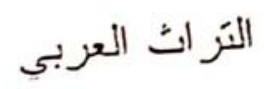

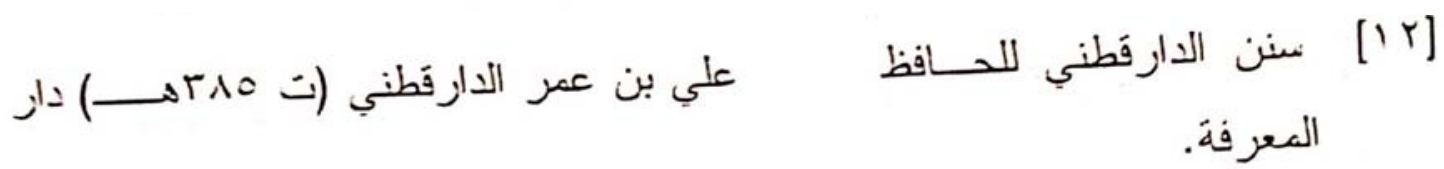

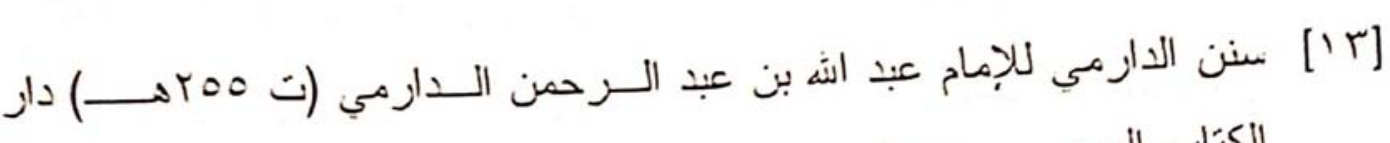

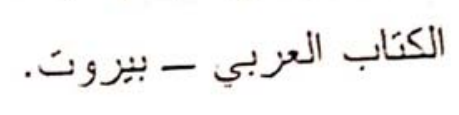

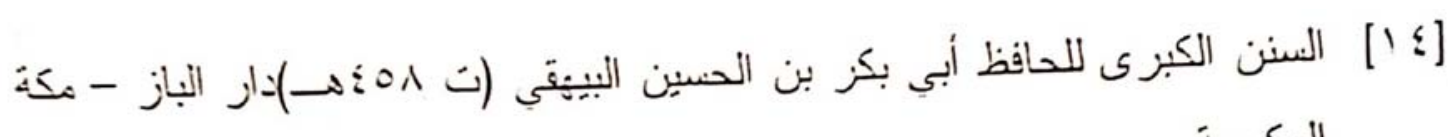
المكرية.

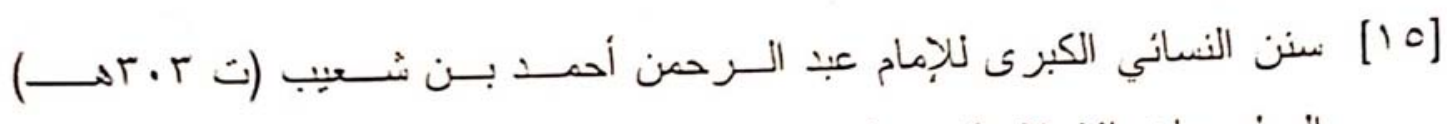

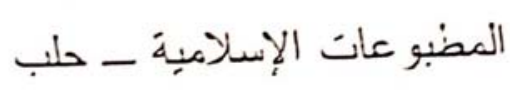

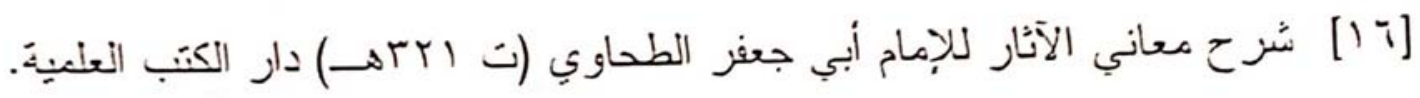

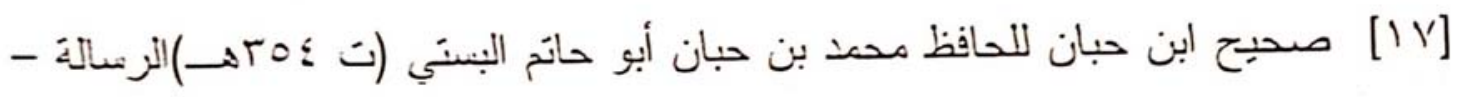
بيزوت.

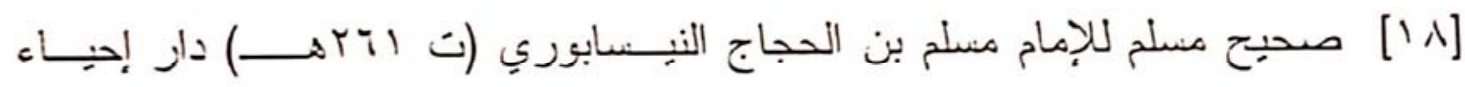

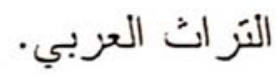

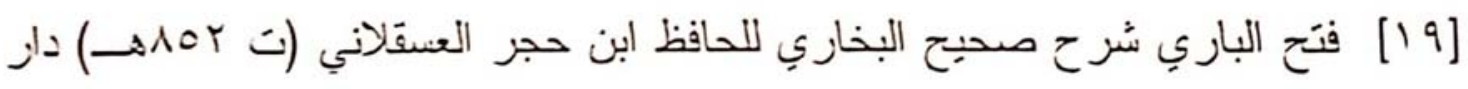
الزيان.

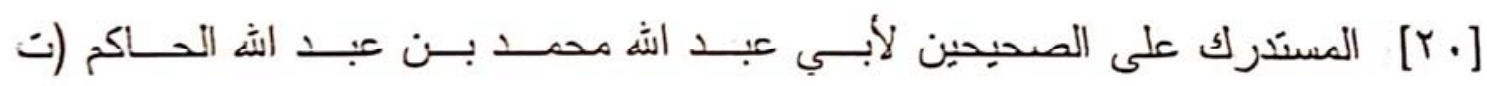
هـ عـــار الكنب العلمية [ ] المسند للإمام أحمد بن حنبل (ت اعبهــ دار إخباء التزاث العزبي [Yrr] المصنف للإمام أبي بكر بن أبي شيبة (ت مrr هـ) دار الفكر. 


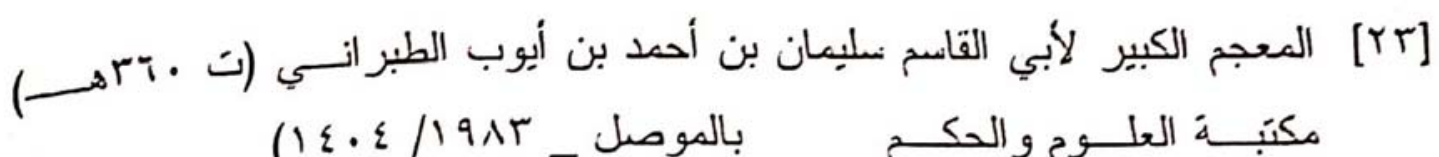

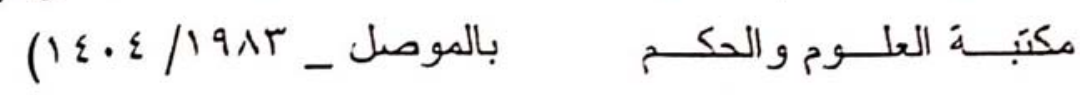

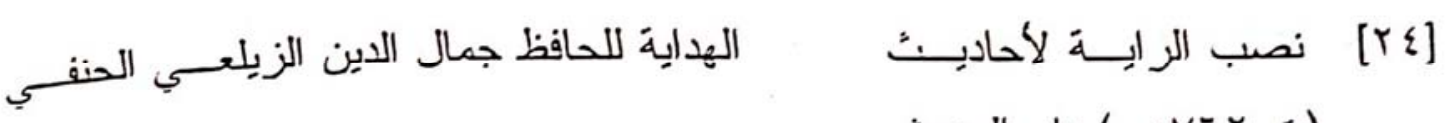

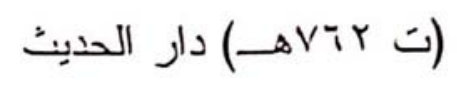

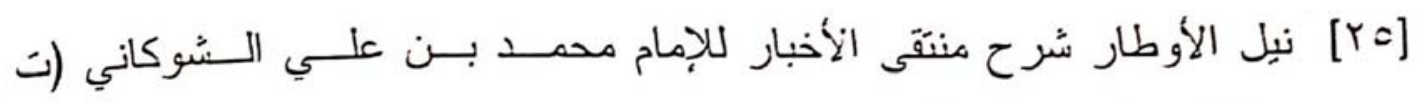

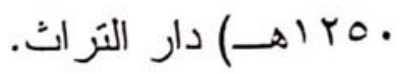

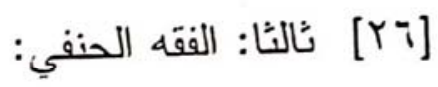

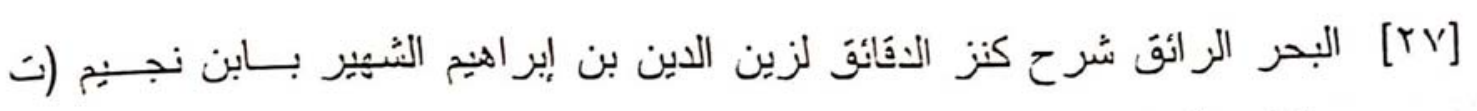
.

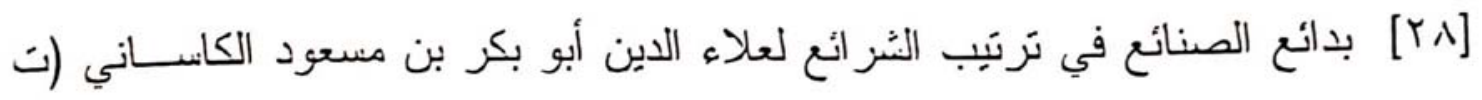

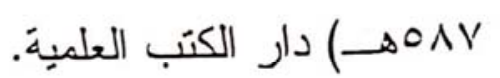

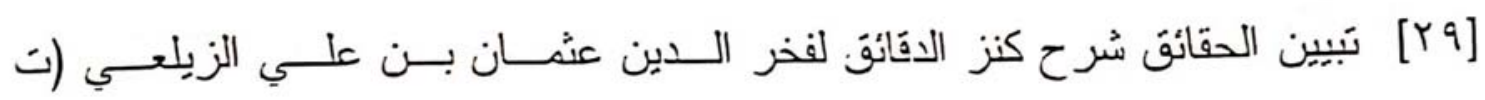

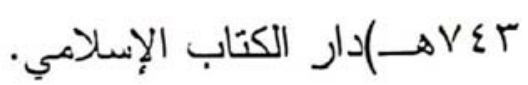

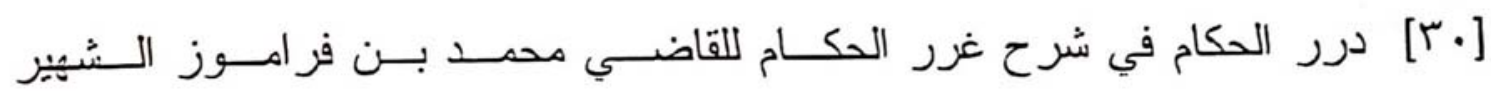

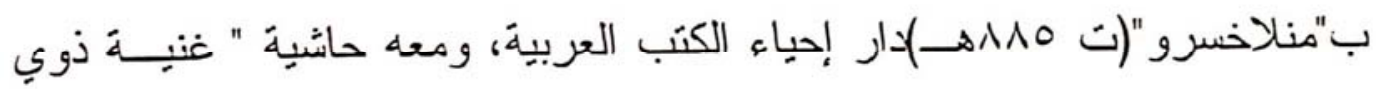

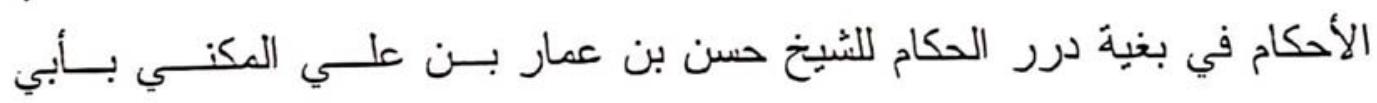

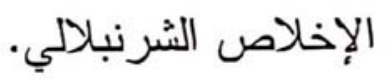

[اب[ رد المحتار على" الدر المختار في شرح تنوير الأبصار (حاشية ابن عابدين) لابن

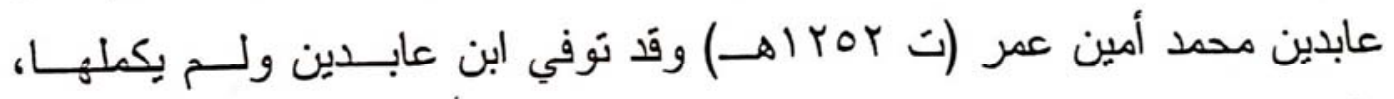

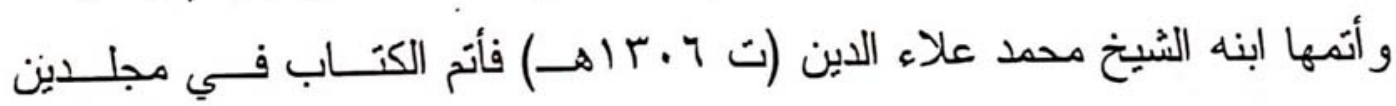
وسماه قرة عيون الأخبار لنكملة رد المحتار - دار الكتب العلمية. 


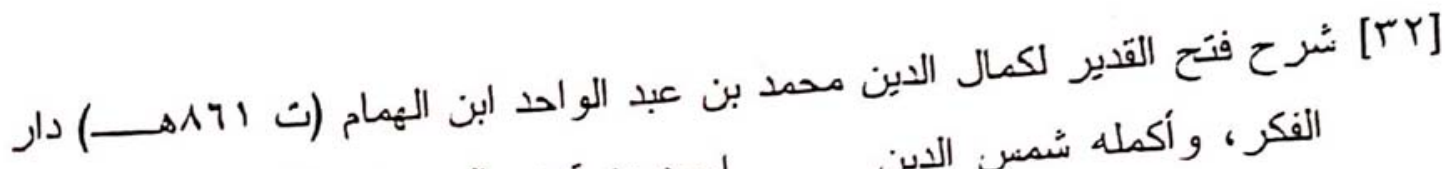

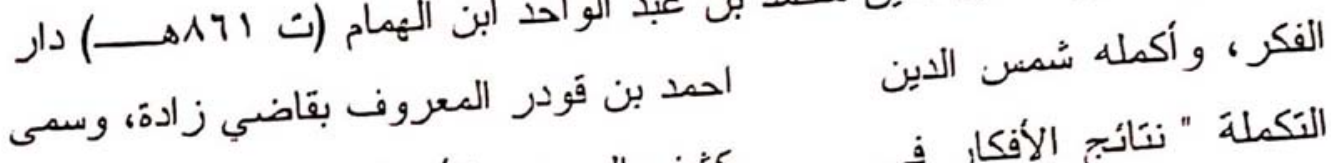

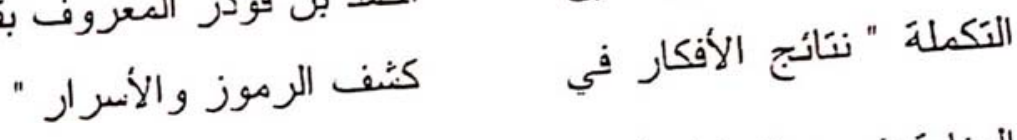

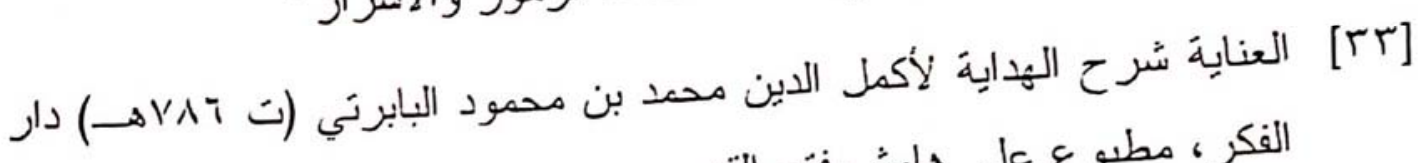

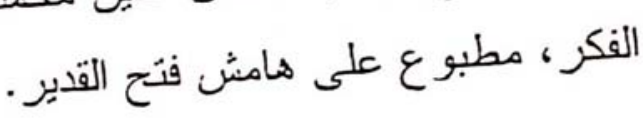

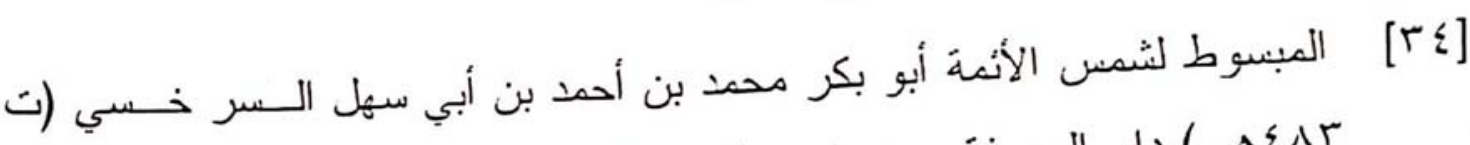

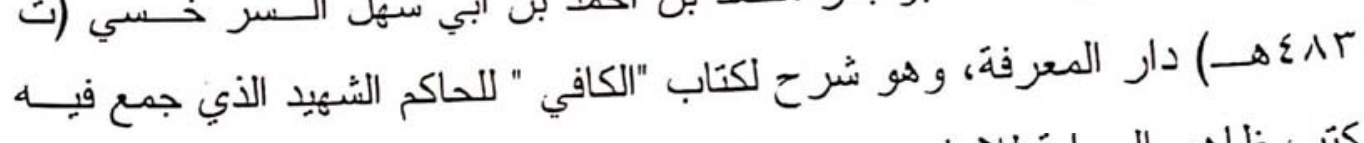

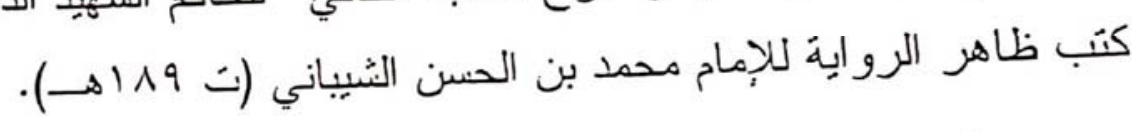

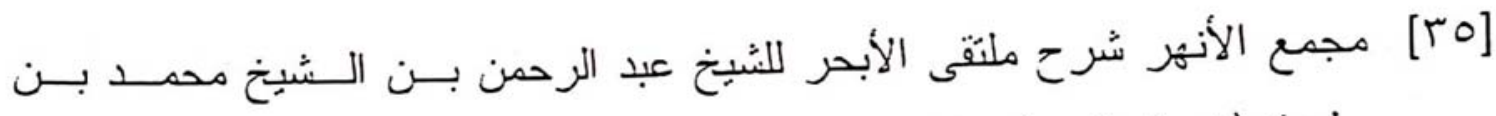
نمليمان(ت 901 هــ):ار إحباء الترات العربي.

[Tr] الهداية شرح بداية المبتكب - كلاهما لشيخ الإسلام برهان علي بن أبــي بكـر

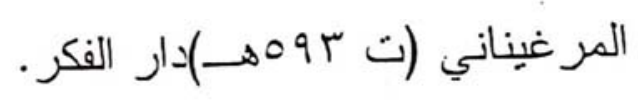
[rv]

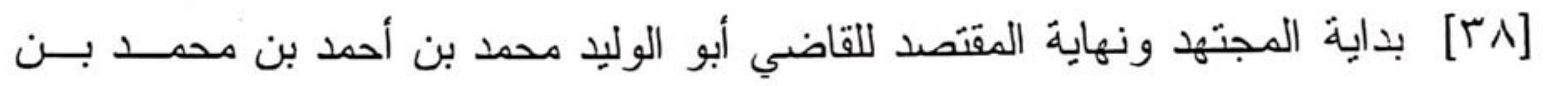

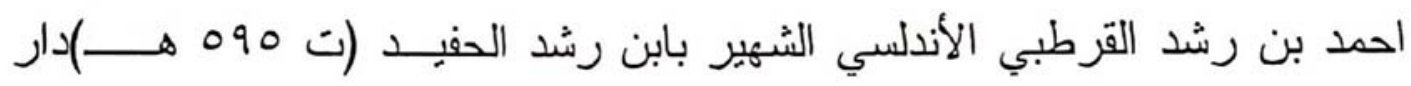
- الفكر

[ج" بلغة السالك لأقرب المسالك (حاشية الصاوي على الثرح الصغير) لاحمد بـن محمد الخلوتي الشهير بالصاوي (ت اع باهـ) دار المعارف مصر.

[ • ع] التاج و الإكليل لمختصر خليل لأبي عبد اله محمد بن يوسف الشهير بالمواق (ت

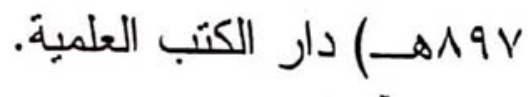

[1] حاشية الاسوفي على الشرح الكبير اللدردير لشمس الدين محمد بن عرفة الدسوقي

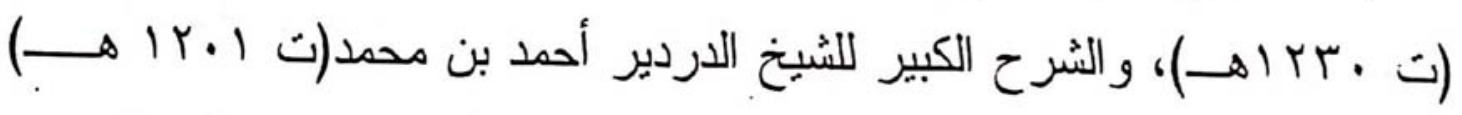
دار إحباء الكتب العربية. 
[ץ؛] حاشية العدوي على كفاية الطالب الرباني لعلي الصعبدي العدوي(ت 1111)

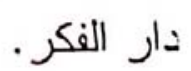

خليـلـل لمحمــــــن عبــــ اله الخرشـي(ت

$$
\text { [r: }
$$

[: : [ الفو اكه الدو اني على رسالة ابن أبي زيد القيرواني لأحمد بن غنيم بن سالم بن

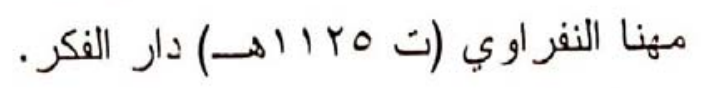

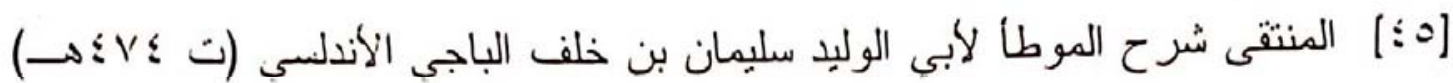
دار الكتاب الإسلامي.

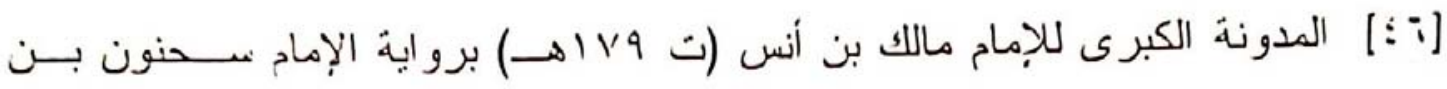
سعيد التنوخي عن الإمام عبد الرحمن بن القاسم عنه - دار الكتب العلمية.

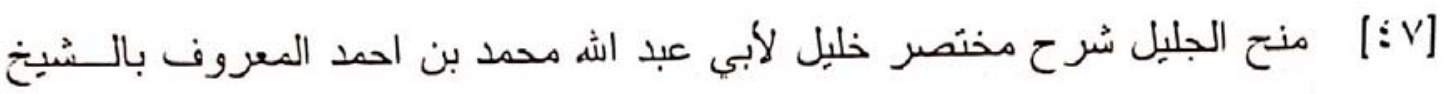

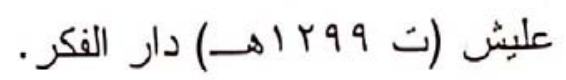

[N! ] مو اهب الجليل شرح مختصر خليل لأبي عبد اله محمد بن محمد بن عبد الرحمن

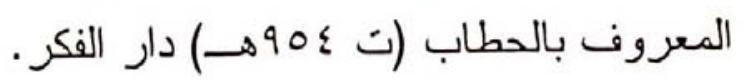

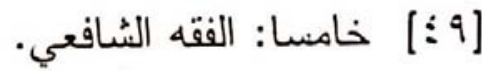

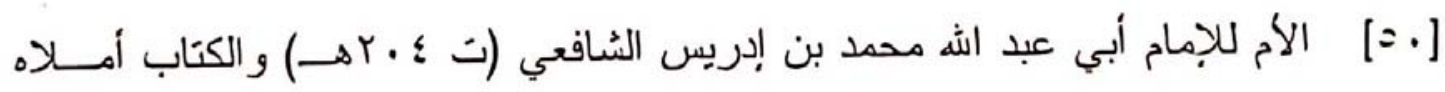
على تلاميذه في مصر و هو يَضمن مذهبه الجديد - عالم المعرفة.

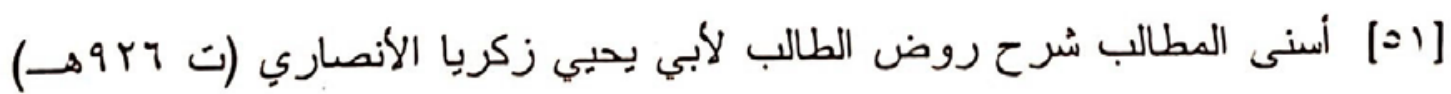

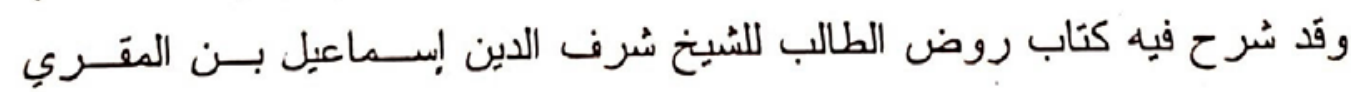
اليمني (ت حrیهـــ) دار الكتاب الإسلامي.

[r=] تحفة الحبيب على شرح الخطيب، المعروفة بحاشية البيجرمــي علـى الخطيـبـ

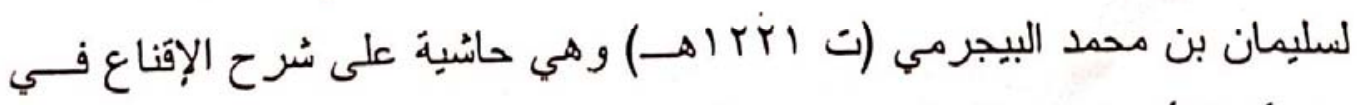
حل ألفاظ أبي شجاع للخطيب - دار الفكر. 


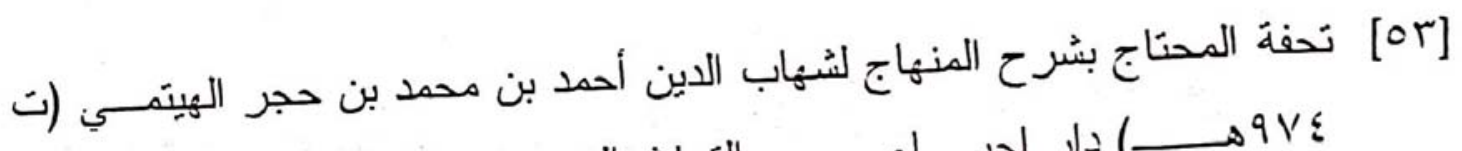

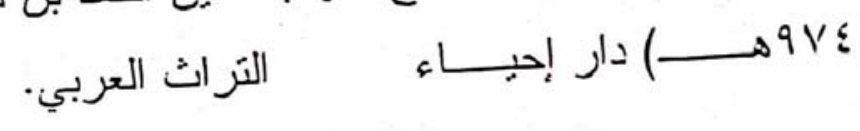

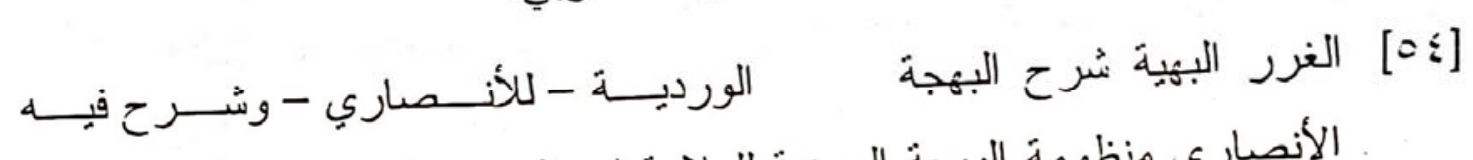

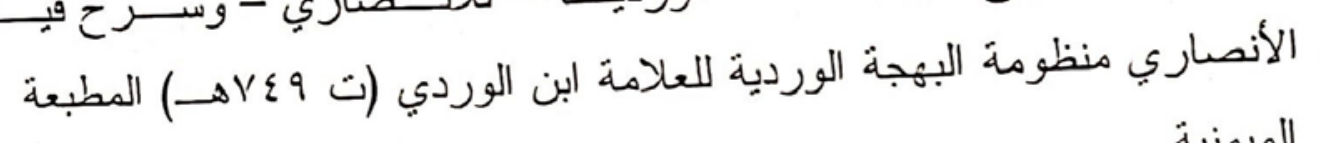

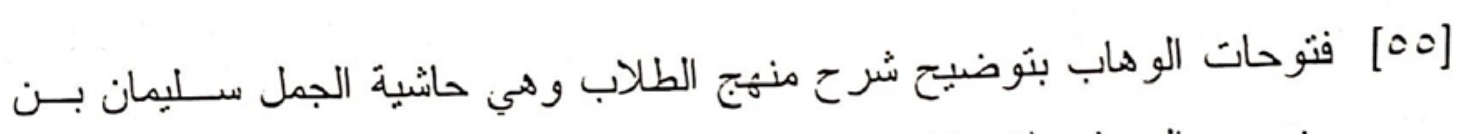

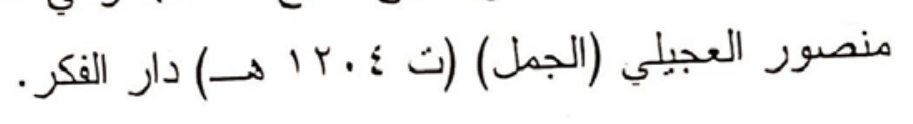

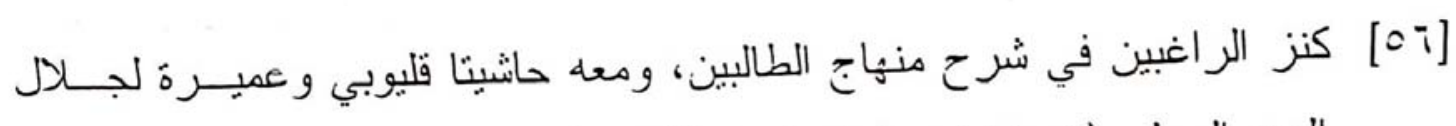
الدين المحلي (ت 7 ؟ههــ) دار إحباء الكتب العربية.

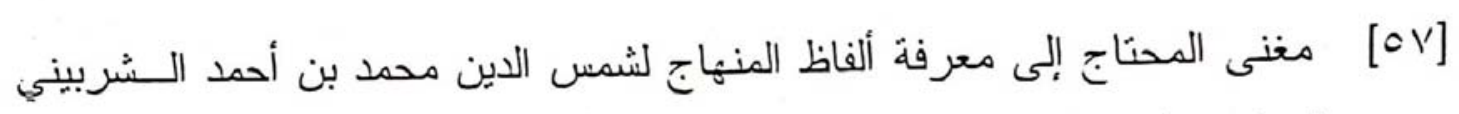

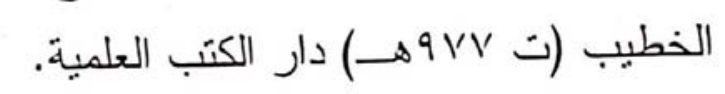

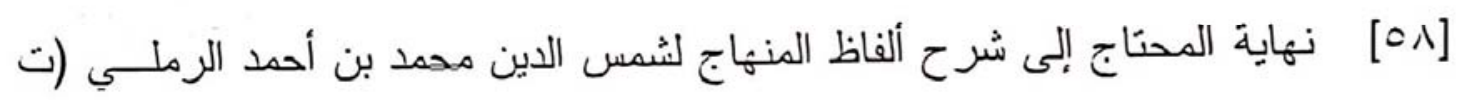

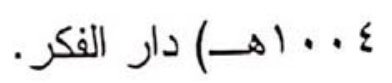

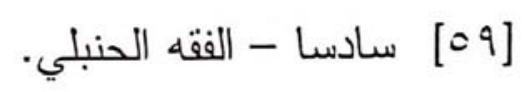

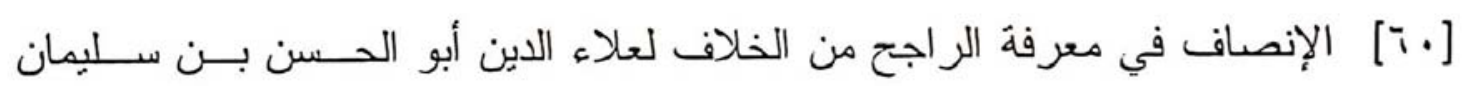
المرداوي (ت 1110هـــ دار إحباء التزراث العربي.

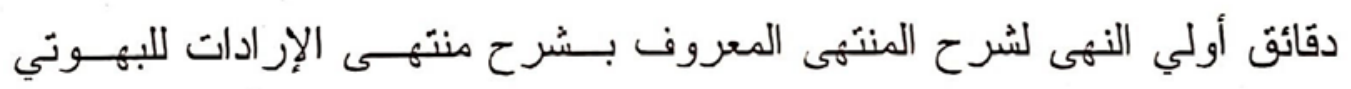

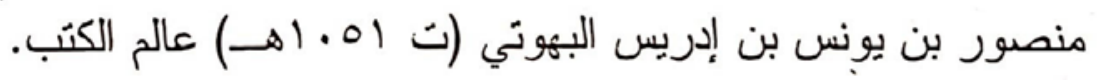

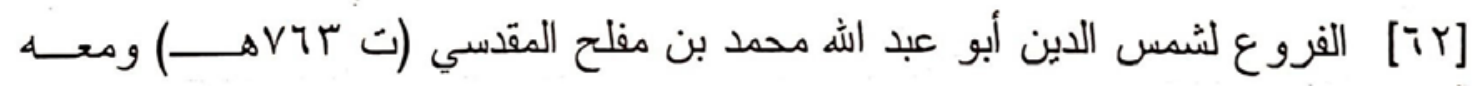
تصحيح الفرو ع للعلامة يوسف محمد المرداوي الحنبلي - عالم الكتب.

[זד] كشاف ألقناع عن متن الإقناع للبهوتي - دار الكتب العلمية.

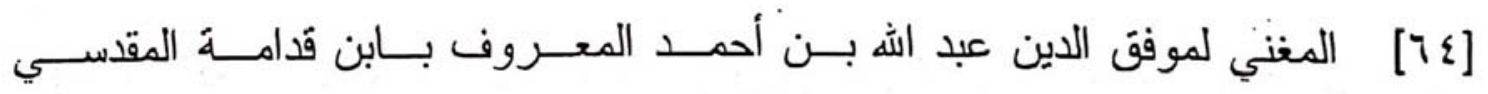

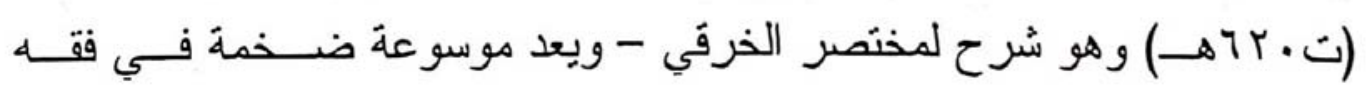




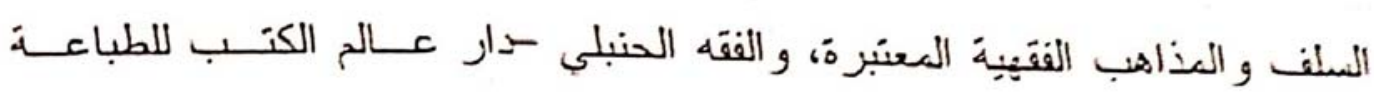

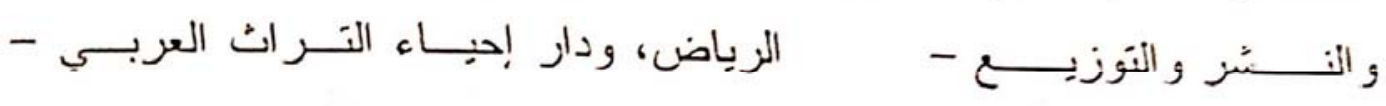
بيزوت.

[آ] [ابعا: الفَّه الظاهزي.

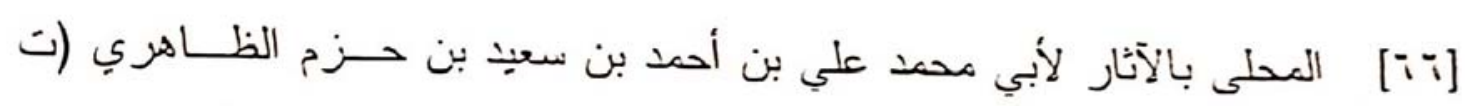

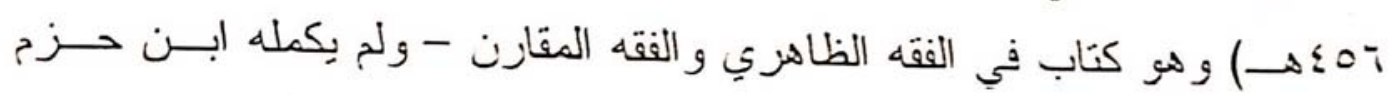

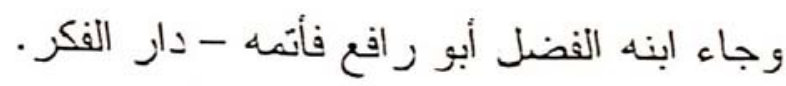

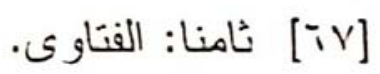

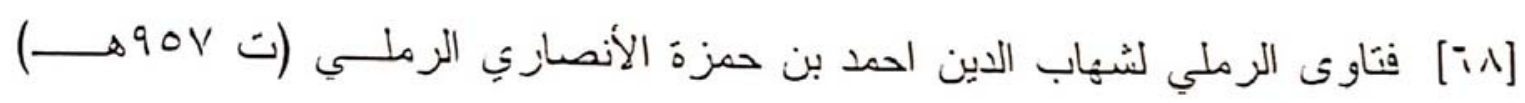

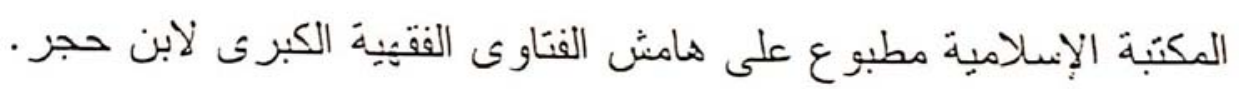
[iq] فتّح العلي المالك في الفنوى على مذهب الإمام ماللك لأبي عبد اله محمد بن أحمد

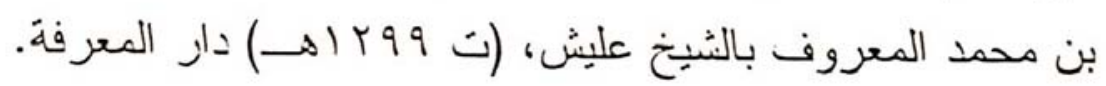

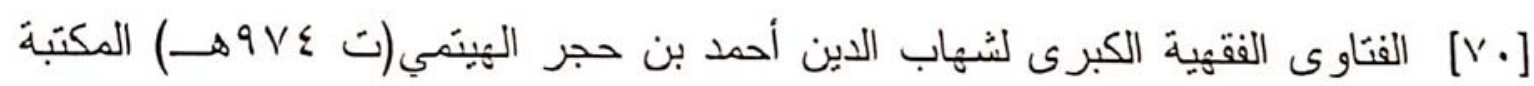
الإسلامية

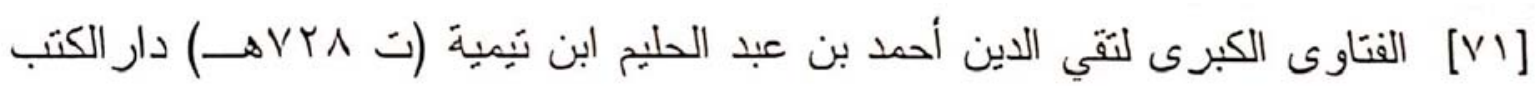
العلمية.

[Yr] الفتاوى الهندية لجماعة من علماء الهند - وهي ليست فتاوى بالمعنى المعـروف

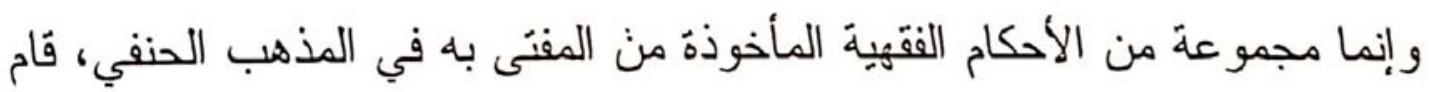

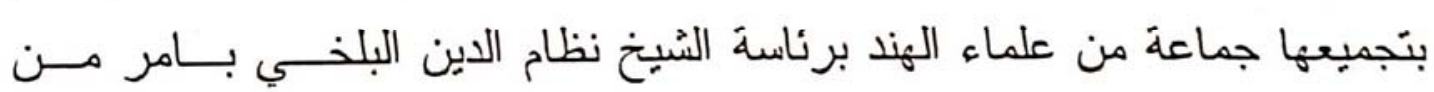
سلطان الهند أبي المظفر محيي الدين محمد أورنك - دار الفكر.

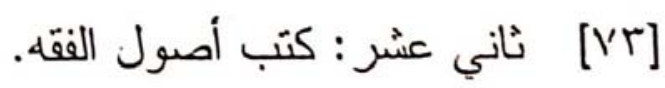

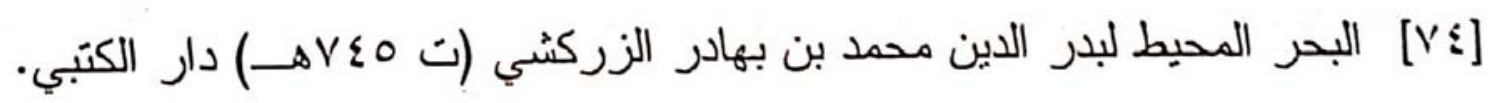




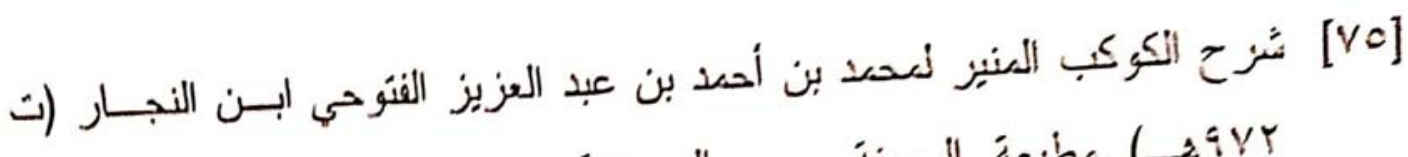

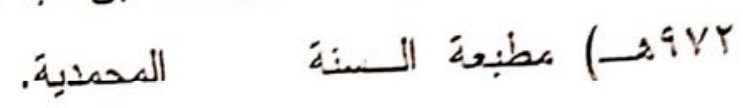

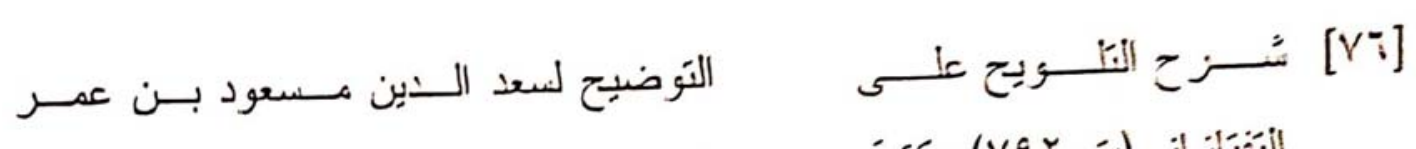

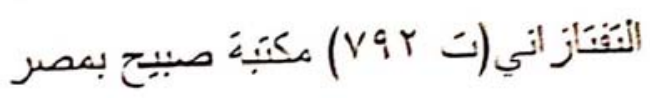

[VV] الأوقَانت الكوبيَّةَ.

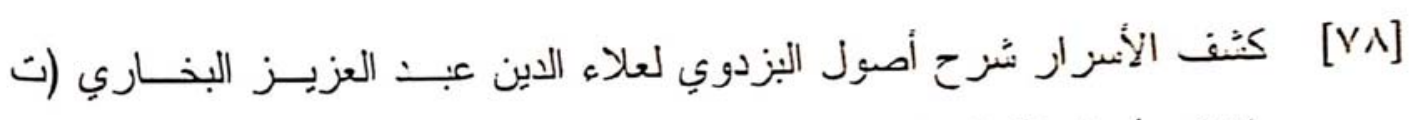

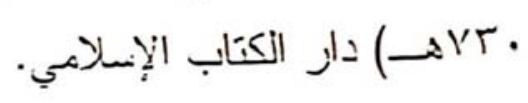

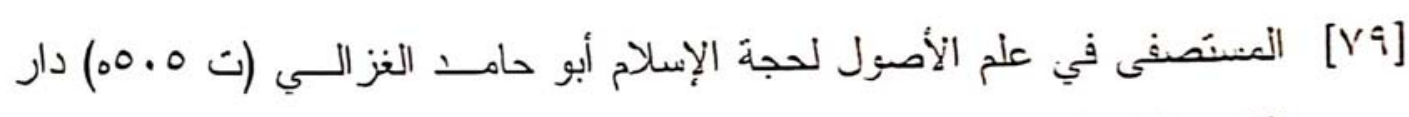
الكتب العلمبة.

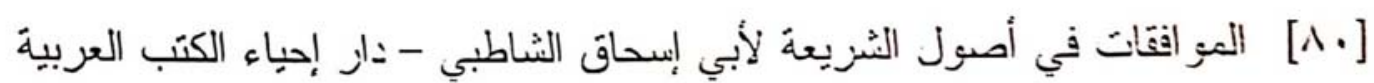

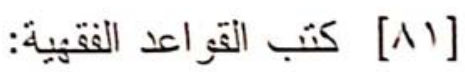

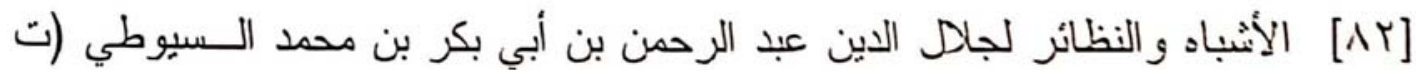
(- مار الكتب العلمبة

[^] أنو ار البروف في أنواع الفروق لشهاب الدين أبو العبـاس أحمــد بـن إدريـس

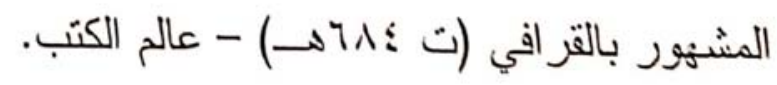

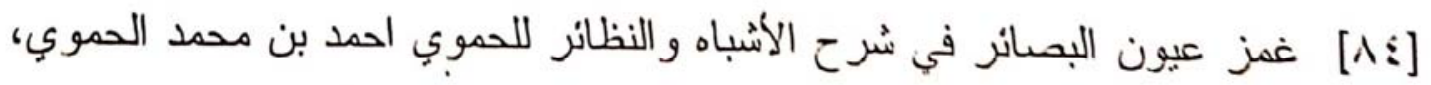
و هو شر ح للأشباه والنظائر لابن نجيم الحنفي - دار الكتب العلمية.

[10] قيو اعد الأحكام في مصدالح الأنام، ابو محمد عز الدين بن عبد العزيز بــن عبـــ

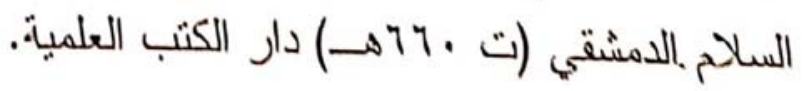

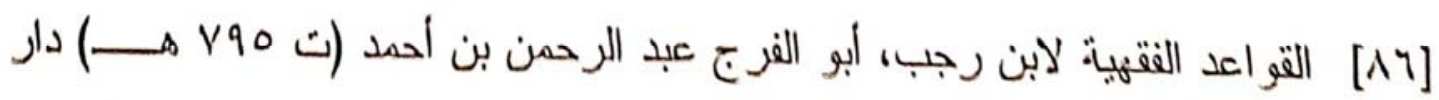
المعرفة. 
V9 المنتور في القو اعد لبدر الدين محمد بن بهادر بن عبد اله الزركسشي (AV]

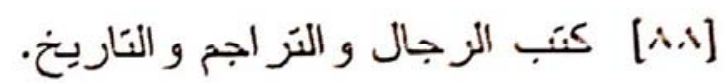

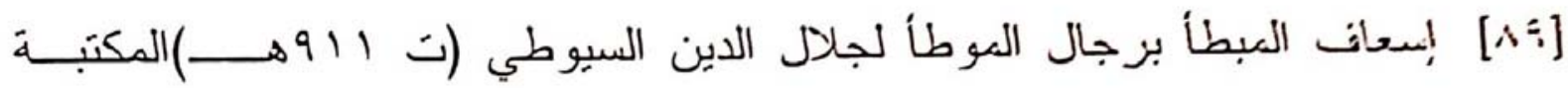

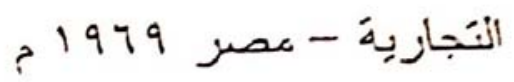

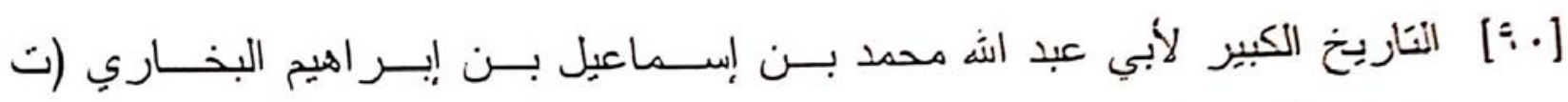

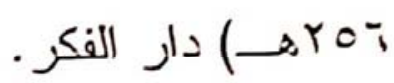

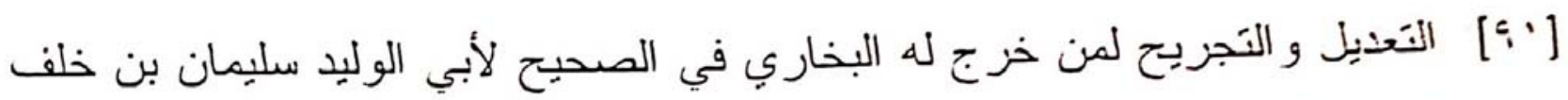

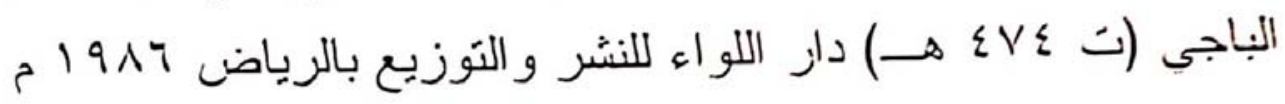

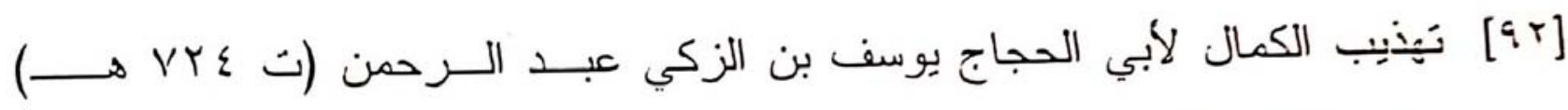

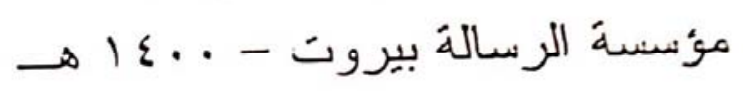

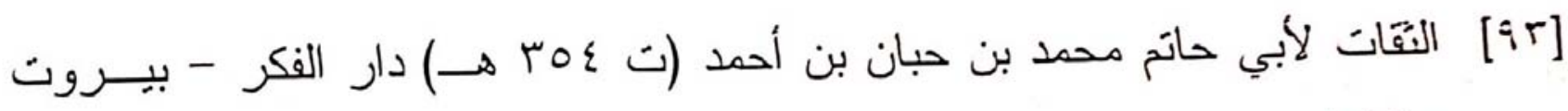
.1980

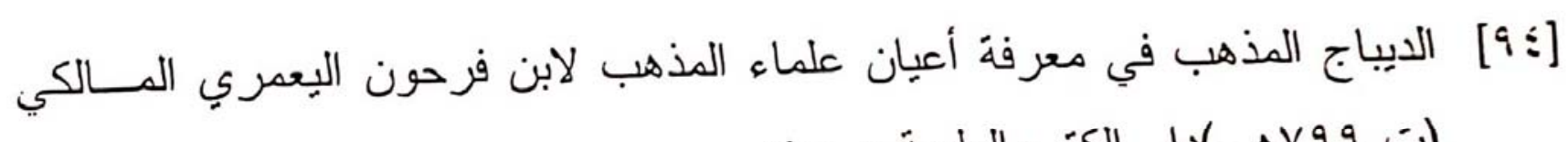

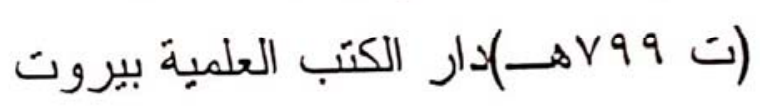

[9 [9] الطبقات الكبرى لأبي عبد اله محمد بن سعد بن منيع (ت . سبهـ)دار صــادر بيروت.

[ [97] [i كنب معاصرة: الرسالة

[9،] الملكية في الشربعة الإسلاميةَ للشيخ علي الخفيف - دار الفكر العربي 


$$
\begin{aligned}
& \text { [99] الملكية ونظرية العقد للشيخخ أبو زهرة - دار الفكر العربي. }
\end{aligned}
$$

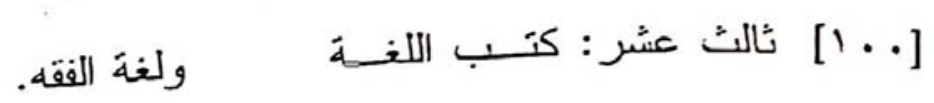

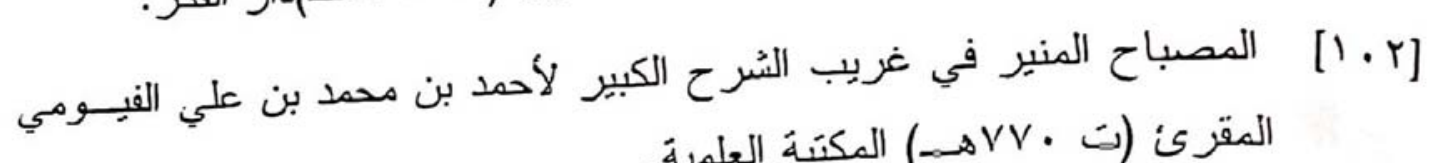

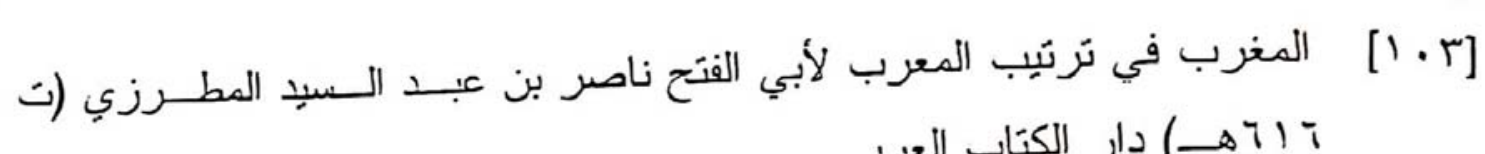

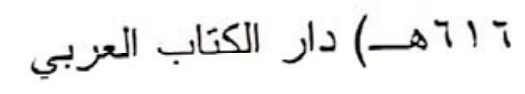

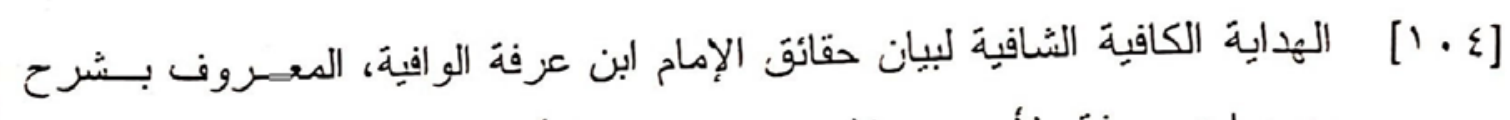

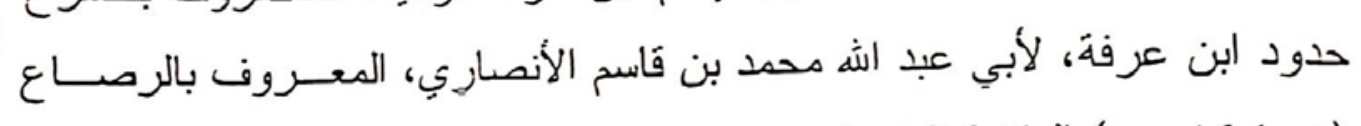

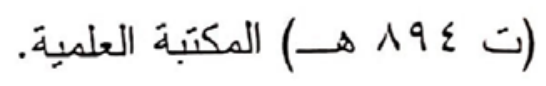




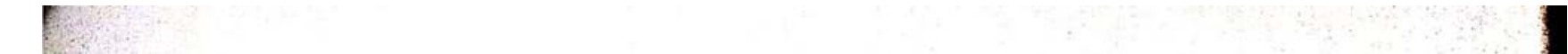

